\title{
SOIL AND WATER RESOURCES OF
} SOUTHWEST AFGHANISTAN

\begin{abstract}
of study of soits, climate, drainage. and agriculture summarizing present and potential irrigation development and the problems of derelopment.
\end{abstract}




\section{INDSEX To CONTENS}

GHAPTER - SECTION THLE PACB

I
1.
2.
3.

II

1.

2.

3.

40

A. Population, Living Standasds, Food Consumption.............

B. Correlation of Population, Food Consumption, Crop Acreage

\& Ylolds_.........................................

C. Livestock Produotion . . o ............................

D. Summary of Present Agricultural Production...............

III

1.

a. The Arghandab System, ................

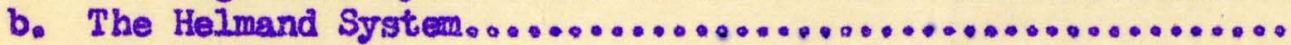

c. Other Streans

d. Flood Hzzards............................................

๑. Quality of Surface Waters.

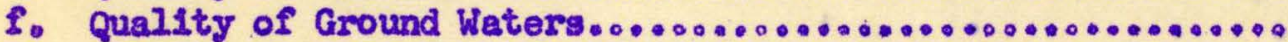

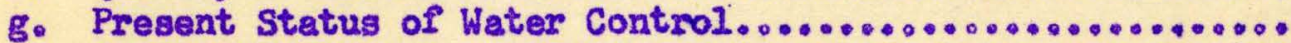

h. Arghendab Water Use EffIcioncies.........................

2. b.

c.

SOII. RESOURCES

Soll Survey Reports \& Maps_p.........

a. How a Soll Survey is Made..................................

b. How to Use the Maps \& Reportas................................

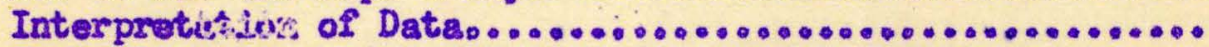
Characterist1cs of Southwest Afghanietan So1ls............ General Oxigin \& Development of Solls....................... Principal Physical Properties............................ S1te Factors Affecting Reclamation \& Dse...................

LAND BFCLAMATION \& TREATMENT...................... Land Clearing \& Leveling ............................

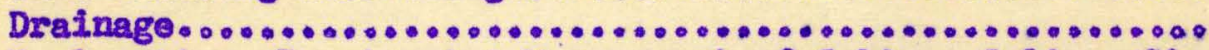
Reclamation, Treatment \& Management of Saline, Saline-Alkali So11s.......................................... Wind Erosion Control......... $000000 \ldots \ldots \ldots \ldots \ldots \ldots \ldots \ldots \ldots \ldots$ Control of Vegetation in Canals \& Drains.................... Flood Control.
1

1

2

2

5

5 
Plant Grouth Hablts Affecting Water Ise.

b. Cropping Practicen for Fffielent Use.......................

c. Methods of Computing Water Use...ven........................

d. Wator Requirements of Crops Grown in S. W. Afghanistan....

VII

10

TI.LAGE \& WATER USE PRACTTCES

2.

\section{a.}

Water Management. ......................................

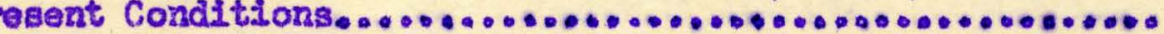

b. Inprovement of Water Ise Pract1cea............................

c. Adapting Irrigation Systems to Soll Conditions.............

POTBNYIAL ACRTCULTURAT DEVIELPMOUV \& ECONOME
1.

20

3.

40 5. Eatimates of Past \& Present Production........................ Sumary of Presemty Irrigated \& Potentially Irrolgabie

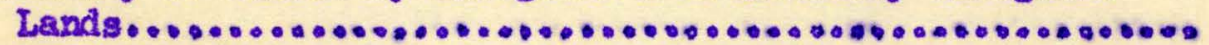

Costs of Development......................................

Income Potentials \& Relation to Costs......................

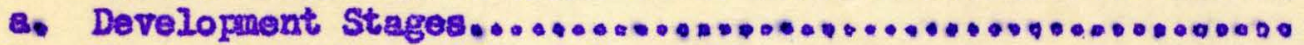

b. Production Potentials \& Crop Values........................... Overall Development Costs \& Production Potent1als...........

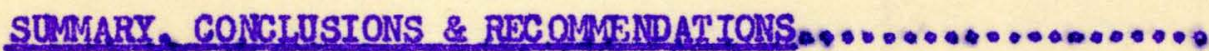


1 Surnmary Status of Helmand Valley Agricultural Surveys \& Out-ol-Contract

Agricultural Surveys..............................................

S. W. Afghani จtan Climate - Monthly \& Mean Annual Temperature.............

3 Average Effect of Climate on Irrigation Requirementa in S. W. Afghanistan

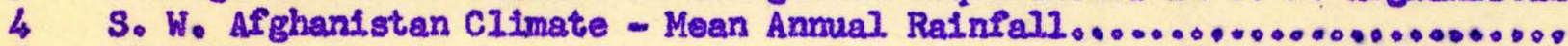

5 Climate...........................................................

6 A Comparison of Monthly Average Wind Velocities at General S. W. Afghan-

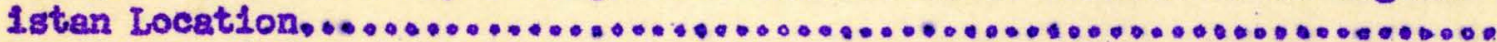

Comparison of Measured \& Calculated Evaporation for Helmand Valley Areas.

8 Comparison of Irrigation Requirements by Different Methoda................

Vegetation of S. W. Afghanistan.............

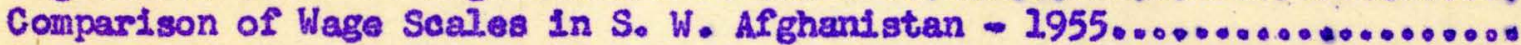

Comparison of Expenditures for Living \& Other Expenges for Various Income

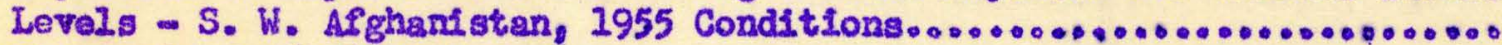

A Comparison of Diets \& Costs...........................................

Barsar Prlees for Agricul tural Products at Kandahar.......................

J. S. Food Consumption Data. $\ldots \ldots \ldots \ldots \ldots \ldots \ldots \ldots \ldots \ldots \ldots \ldots \ldots \ldots \ldots \ldots \ldots \ldots \ldots \ldots \ldots \ldots$

Cost of Ilving Index Based on Wage Earnings \& Relative Food Costs..........

Estimated Present \& Potential Consunption of Food Products in S. W. Af-

ghanistan........................................................

A Comparison of Metpods of Estimating Crop Acreages \& Crop Ilelds - S. W.

Afghanl stan..................................................

Adjusted Percentage \& Acres In Crops for Areas Now Irrigated \& Reachable

By Helmand - Arghandab Water............................................

IIvestock Valves. .............................................

Estimated Present Produotion \& Value of Crops Grown in S. W. Afghanistan. Crop Production \& Crop Values - Federal Reclamation Projects - I955...... Infín Measurements - Arghandab Dam.................................. Arghandab River Water Ese.............................................

A Study of Water Flow at Arghandab \& Kala Bist With Reference to Crop Use

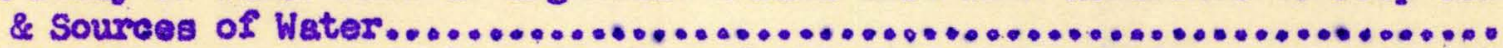

Helmand River at Kajaka1 - Summary of Rrunoff in Acrenfeet.................. Estimate for the Mean Monthly Discharge of the Helmand River in Cuble Feet a Second During A Period of 30 Years from 1872 to 1901 , or the Perlod

Between the Years the River Dried up Below Chaharburjak in the Hot Season

Helmand River Water Use............................................

A Study of Helnand River Flow at Kajakai \& Chaharburjak With Reforence to

Crop Use \& Sources of Water..........................................

Summary of Strean Flow Data For Other Streams...........................

31 General Estimates of Discharge of Streams Emptying Into Chakansur Basin

With Reference to Aveilable Source Date................................. Analysis of Aceumulative Flood Volumes in 1903 Flood Acre/Feet............ Summary of Surface Water Resources.................................... Helmand-Arghandab Ground Water Analyses of quality....................... Overall Arghandab-Tarnak Water Resources \& Water Use as Represented By

DLfferent Analyses _..............................................

Losses \& Waste of IrrIgation Water.................................... 
Drainability Classification of Projoct Aroas............................. Sumary of Saline \& Alkali Condition of All Laboratory Semples To Date.. A Study of the Relation of Soll Salinity \& Alkalinity To Ciessification of Solls Mapped In Helmand Basin........................................ Suggested Drainability Limits For Land Classes in Irrigated Areas........ Examples of Drainability \& Calculations................................

_...

Irr1gation Drainage Requirements - GFS/Acre........................ Summary of Leaching Trials............................................. Infiltration Properties of Soils.................................... Boron Content of Soils Tested....................................... Laboratory Results of Complete Leaching of Highly Salino-Alkeli So1ls... Relative Tolerance of Plants to Salts..................................... Root Distribution of Crops Growing in Normel, Well-Drained Soils........ Computation of Consumptive Use Factors for Central Helmand Valley Area.. Computation of Consumptive Use Factors for Lower Helmand Areas............ Calculated Normal Crop Growth \& Water Use................................. Water Requirements HeImand Valley Projects................................ Additions \& Removal of Nitrogen...................................... Plant Food Requirements For Different Levels of Production............... Plant Nutrients in One Ton of Different Manures............................ Average Analysis of Organic Materials................................... Estinated Gross Fertilizer Needs of S. W. Afghanletan When Fully Developed Under Irrigation................................................. Practical Interpretation Chart For Soll Moisture.......................... Border Irrigation Table..................................................

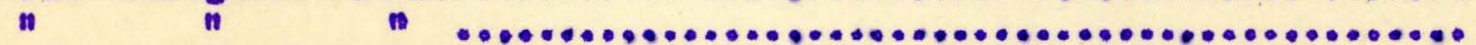
Border \& Border-Check Basin Irrigation of S. W. Afghanistan Solls....... Suggested Practical Border Sizes for Afghan Farm Units..................... Estimated Benefits of the Helmand Valley Development Progrem on necessary Lands Annually Farmed in the Helmand-Arghandab Watershed Areas....

S. W. Afghanistan Irrigable Land Areas.................................. Sumary of Irrigable Land Classes - S. W. Afghanistan.................... A.C.V. Development Cost Estimates Made For 1954 Projects............... An Unofficial Estimated Cost of Development of Certain Helmand Valley

Lands.............................................................

Proposed Distribution of Land Settlement Charges to Settlers............. S. W. Afghanistan Crop Production-Value Index.......................... Comparative Production Value of Farm SIzes Suggested by HVA for Various

Classes of Land.......................................................

75 A Comparison of Proposed Land Allotments \& Allocations of Costs to

Settlers W1th Total Land \& Water Resource Development Costs............... Adjusted Costs of Development \& Gross Production Values By Land Classes.

A sumary of Estimates os Costs, Produetion at Full Dovelopment a

BeneritsCost Ratios................................................... 
LD 130 Climate \& Water Use.

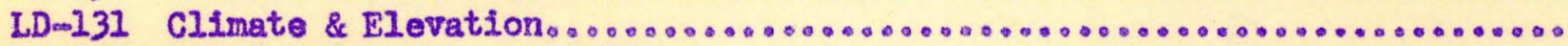

LD-139 Growing Season - Kandahar. $\ldots$.

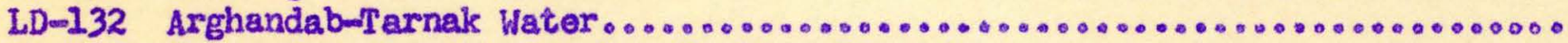

LD-133 HeInand-Arghandab Gauging Station Records...........................

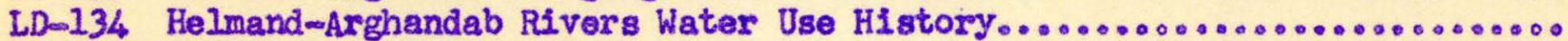

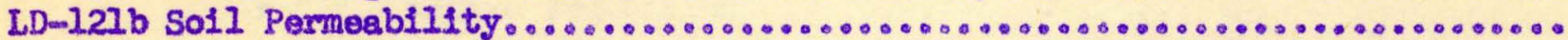

LD-115 S. W. Afghanistan Soils - General Relation of Saturation Percentage,

Texturel Grades, Fleld Permeability \& Available Moisture.............

LD-135 Nad-I $\rightarrow$ All - Drain Water Analyses ..................................

Fig. I ICA Reclamation Plots at FOA Demonstration Farm Lashkari Bazaar........

Bed \& Furrow Irrigation of Saline Soils. $\ldots \ldots \ldots \ldots \ldots \ldots \ldots \ldots \ldots \ldots \ldots \ldots$ 


\section{APPENDTCES}

NUMBER

APPENDIX I - CLMATIC TABIES $\ldots \ldots \ldots \ldots \ldots \ldots \ldots \ldots \ldots \ldots \ldots \ldots \ldots \ldots \ldots \ldots \ldots \ldots \ldots \ldots 0$ Arghandab $\ldots \ldots \ldots \ldots \ldots \ldots \ldots \ldots \ldots \ldots \ldots \ldots \ldots \ldots \ldots \ldots \ldots \ldots \ldots \ldots \ldots \ldots \ldots \ldots \ldots \ldots \ldots \ldots \ldots \ldots \ldots \ldots \ldots \ldots$ Chah-I-Anjlrs ..............................................

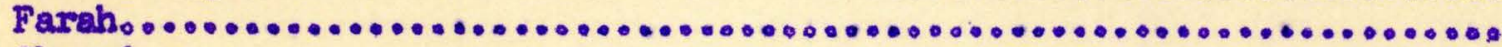

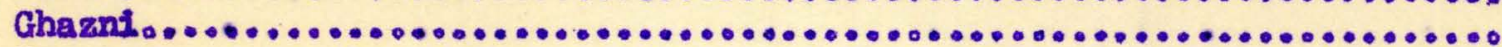

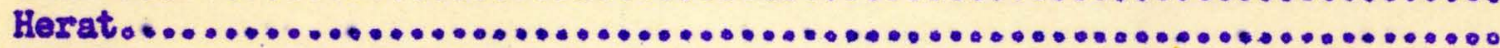

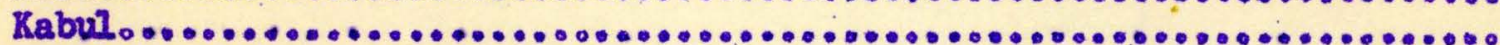

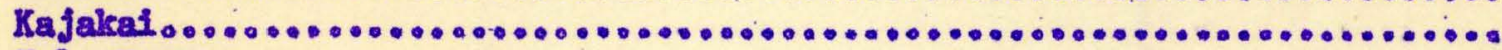

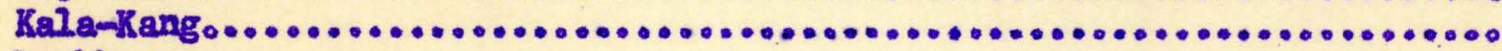
Isashkarga $\ldots \ldots \ldots \ldots \ldots \ldots \ldots \ldots \ldots \ldots \ldots \ldots \ldots \ldots \ldots \ldots \ldots \ldots \ldots \ldots \ldots \ldots \ldots \ldots \ldots \ldots \ldots \ldots \ldots \ldots \ldots \ldots \ldots \ldots$

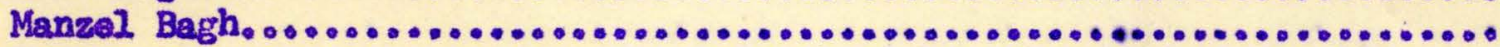
Marfa. ..........................................................

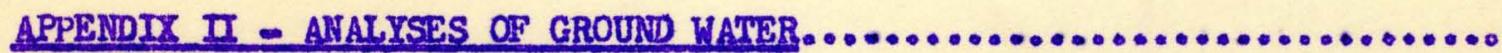
Arghandab. ................................................... Darweshan....................................................... Desht-I-Bakwa. ..................................................

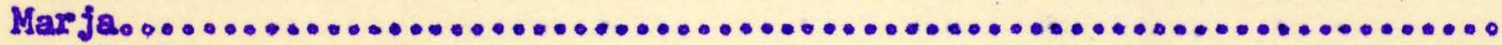

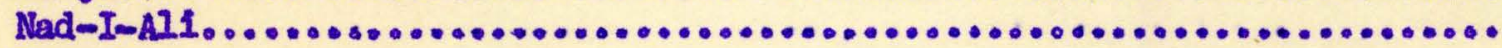
Tarnak. _....... Other Areas. $\ldots \ldots \ldots \ldots \ldots \ldots \ldots \ldots \ldots \ldots \ldots \ldots \ldots \ldots \ldots \ldots \ldots \ldots \ldots \ldots \ldots \ldots \ldots \ldots \ldots \ldots \ldots \ldots \ldots \ldots \ldots \ldots \ldots \ldots$

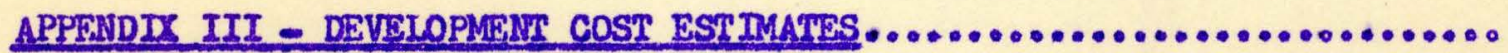

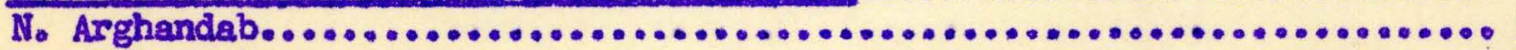

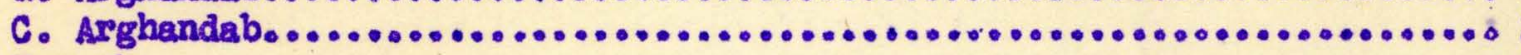

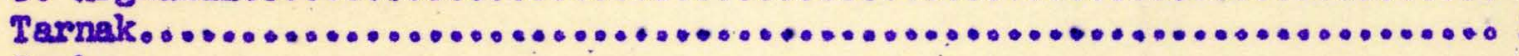

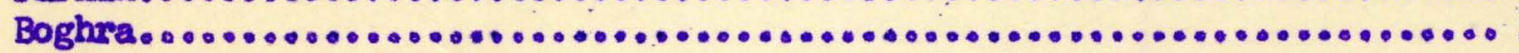

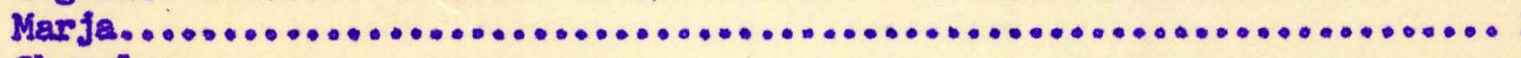

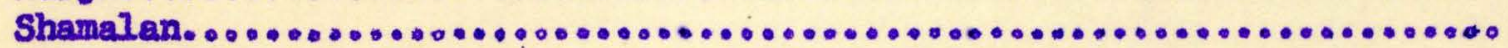

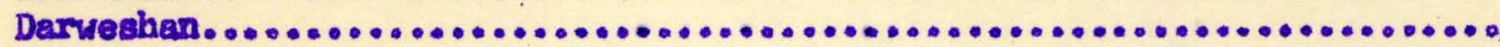

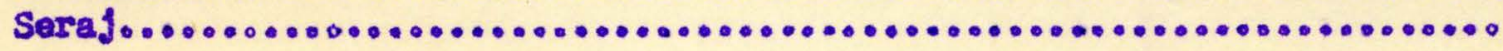




\section{INRRODLeT TON:}

\section{Organt.ration and Plong for Survers and Roportso}

The need for adequate and rollable 1nformation regarding the solis and

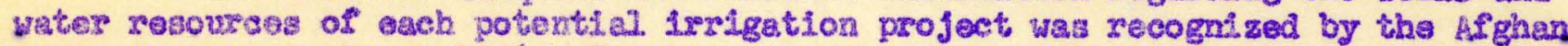
Governnent as bexly as 1946. Fxank 0. Youngs, then employed by Morsison-lunüen Asghanisten, Ine., mede preilninary bolls surveys and Investigetions of a nuber" of arøas 2n S. W. Agghantstan and reportod his flndinge to tho government.

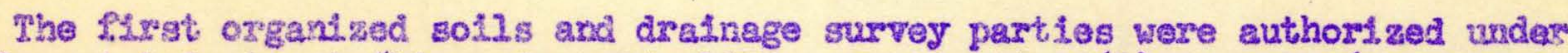
Supplenentel Contract $/ 20$ or June 25, 1953. Section I B (1) stated "(the Compary) shal2 make goneral murveys of

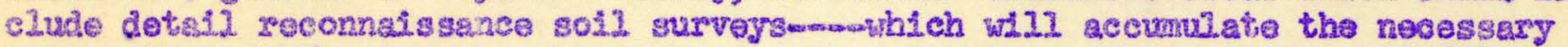
inforwation Sor Long range planning of valley developaratt a Sagtion I B (2) states " (company will prepare)..... juetlficstion reports of supfielent detail to use as

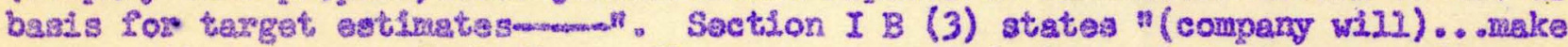

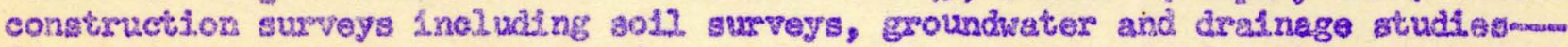
for projects now belag prepared for conatzuctlon-mono apecifically-m-Arghardab Valley, Marja and Shamalan areagmens".

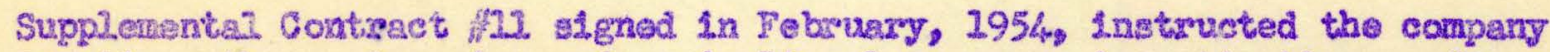

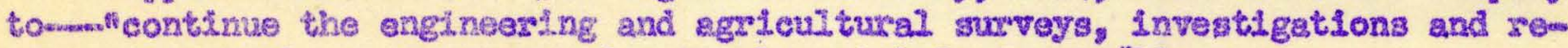
poxtis, currantly proceeding under Supplenentel Contract Hamm.

The 2954, Prime Contract sIgned June 21, 1954, Axt, I, Section D, Btetes

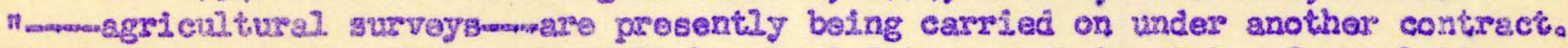
It is intended that this wor\% shall bo carried to a cestain atate of completion

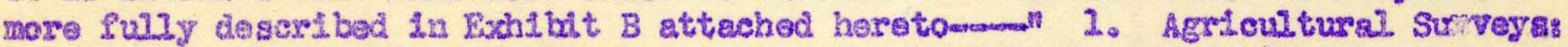
a. Agrleultural Deta11 Sol1 Surreys in Tamak, Axghandeb, Saral, Shenalan and Dexweshar aseas. b. Agricultural Detall Reconnaisaance Solis Surveys In the Seraj and Daxweshen Arass. G. AgrLeulthyel Ground Water and Dralnage \$rrveys in the Tarnsk, Arghandab, Boghra, Marja, Shemalan, Saraj and Darwoshan Azeas. d. Mineal-

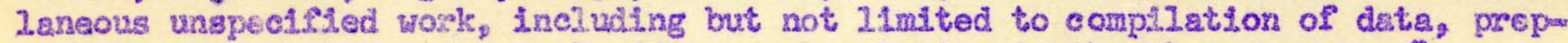
aration of reports and generel office work zelating to the above survays."

In addition to tho euthorities given under principes contracts, several out-ofecontrect and special work orders have been executod. These Inciude:

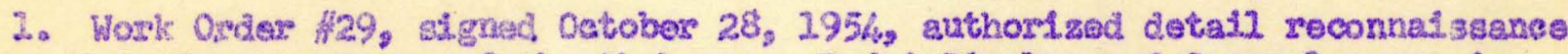

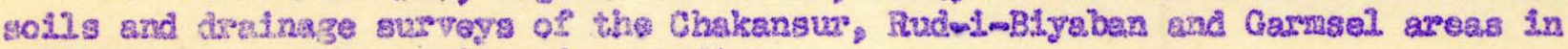
sddthion to certatn angineering stradtos.

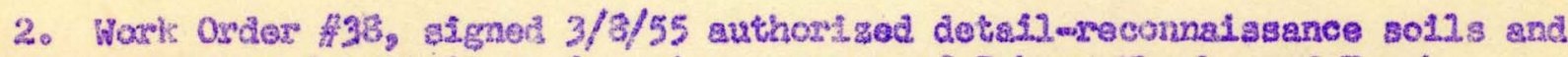

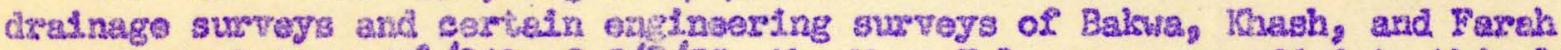
areas. Dy letter $42 / 242$ of $9 / 9 / 55$, the Mras Kata ares was added to this 11 sto

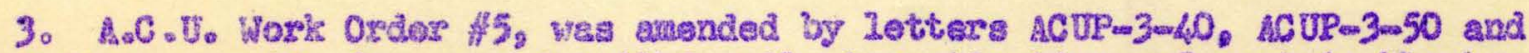

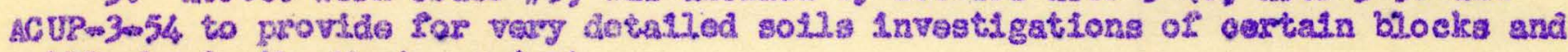

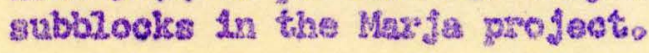




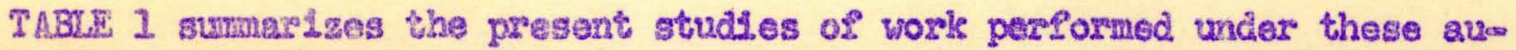
thor2zations and other letters and sgreenents on 110. A more complete 11 . 1 t of drexings, naps, reports and spactal studles are listed in the appendlx hereto and under asch asea supplement。

\section{Purpose of Survere and Benosts:}

BxLefly ztatod, the solis and drainablitty surveys, waps and repoxts, are a compliation of detalled observations, measurements and anslyses of the Iand and Its asociated features, ande and interpreted by skillod technicians for tho prinery purposo of deseribing and evalusting the potenti2l use and productivity of a percel of land and the problens inherent ulth 1 ts devolopment and use.

Sunnarized Brom the various contracts and work orders 1istod ebove the speclu IIc purposos of the Hilmand Valley surveys axe to determines

2. The relative suitability for present os potential 12rigation of oach soll

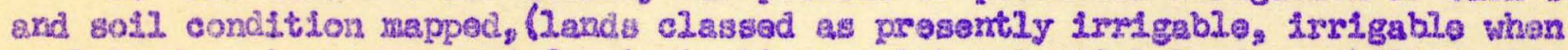

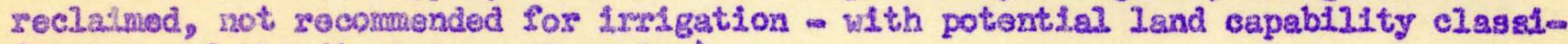
Plcatlon of the Plrgt two catogortes):

2. The linds and relativo degrees of Intensity of problens to bo overcone In developlng and usling the land (a2ts, alkali, wetnoss, leveling, erodibillty, Rlood hazards goll behaviour under Irxigation) :

3. The best sulted crops and sequences of erops for each major group of sol2s and soll conditions:

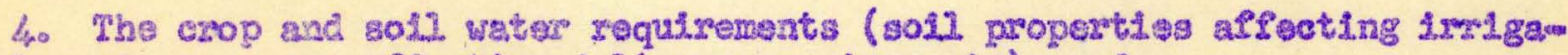
sion layout, erop use affecting delivery requiremonts); and,

5. The nalatiwe economses of developnont and use fostinated dovelopnent costs, gras and not roturns and comtubenelit rationo

\section{Oxgantzation and Presentation of Dath and Raports}

Because of the rolune of dain in the forw of mapg, tables, $20 g_{3}$, it bas boen found impract 1ea], to condenge alf this material into summary reports. Much

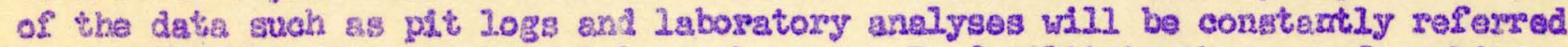
to as developnent progresss into each area. To facilifite the use of working dats as woll as afford a usable bxief report on each projoct the Helnand Vailey Agriloultracl. Surveys are aranged as foliows:

2. Genera? Report:

2. Suppledental reports by areas.

3. Appenditas to stipplemental zeposts contsining legends, sol1 prof110 and deep ptt loge, laboratory anaiyses, infiltiation and Lesching trials and previous prelinalnaxy of 1nteris seporti。 
SUMAARY STATUS OF HELMAND YALLEY AGRICULTURAL SURYEYS AND OUEOOF-GONPRAGE AGRTGULTURAE SURUEYS

\begin{tabular}{|c|c|c|c|c|c|c|}
\hline AREA & AUTHORTYY & $\begin{array}{l}\text { PIELD } \\
\text { WORK BEGAN }\end{array}$ & $\begin{array}{l}\text { FTELD WORK } \\
\text { COMFLJMED }\end{array}$ & $\begin{array}{l}\text { GROSS ACRES } \\
\text { SURVEVD }\end{array}$ & $\begin{array}{l}\text { FINAL MAPS } \\
\text { DRAPIED }\end{array}$ & RYPS OF SURVEX \\
\hline$A x^{\circ}$ handab, No & Sup -Conts 410,12 & March. 3953 & A Aug. 2953 & 167,635 & $111 / 8 / 53.6$ shests & Det Regon Soliz Draín \\
\hline Arghandab, So & $195 / 4$ Prolme Contract & June, 1955 & $\begin{array}{l}\text { Solis } 12 / 55 \\
\text { Dreino } 3 / 56\end{array}$ & 332.220 & $1 / 27 / 566_{2} 10$ " & $\begin{array}{l}\text { Deto So13, Deto Recon } \\
\text { of Draingeg }\end{array}$ \\
\hline Belsive & $W .0, \# 38$ & $\begin{array}{l}32255 \\
2 / 5 / 57\end{array}$ & (รันไม 57$)$ & 275,000 & Not Begur & $\begin{array}{l}\text { Det. Recono - Solig \& } \\
\text { DraAnage }\end{array}$ \\
\hline Chakangur & W. O. & Nov. 1954 & May? 1955 & 554,335 & $\begin{array}{l}1 / 54-4 / 55 \\
34 \text { Shoets }\end{array}$ & $\begin{array}{l}\text { Det, Pocono - So112 \& } \\
\text { Drefnage }\end{array}$ \\
\hline Darwe shar & Sup.Controldog 31 & A48. 1954 & oct. 3954 & 73,10 & $9 / 27 / 55,9$ Sheets & 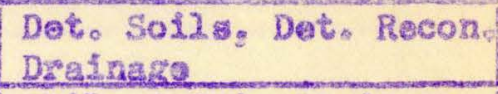 \\
\hline Demwoshan & 1954 Prime Contrget & Juxe, 2956 & Dee。 3956 & 32,500 & $1 / 23 / 57,7$ & $\begin{array}{l}\text { Solis \& Det, DraInsgo } \\
\text { Solected Areas }\end{array}$ \\
\hline Tarah & W.0.th 38 & Not Begun & $-\infty$ & $-=$ & $-\infty$ & \\
\hline Garmsol & 13.0 .439 & Apt. 2955 & May 1955 & 323.800 & $8 / 5731$ Shooty & Roen of Sol18 \\
\hline najakai Wo & Lotior of Roguest. & Nove 1955 & Mov. 3955 & 12,800 & $12 / 1^{7} / 55$ I Sheet & Det Recon solla \& Dr \\
\hline Nesh & $\mathrm{K} . \mathrm{O} .11 \mathrm{f} 38$ & Not Bogun & - & $-\infty-\infty$ & - & - \\
\hline Rarja & Syo.Contr. 110 11 & $10 / 5 / 52$ & $2 / 53$ & 45.000 & $5 / 23 / 53.3$ shoots & Dot Recon solls \& Dro \\
\hline Marje je & $\begin{array}{l}\text { W.Oo\# 5, Lattar: } \\
\text { ACUP }-3=60,50,54\end{array}$ & $10 / 24 / 56$ & $5 / 25 / 57$ & 35,000 & $\begin{array}{l}11 / 1 / 56-8 / 57 \\
55 \text { Sheets }\end{array}$ & 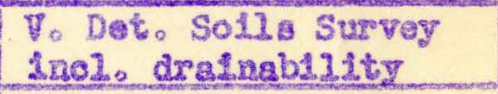 \\
\hline Musa Kala & W.0." 38 by Lettor & Nos Begun & $=0$ & $-5=$ & $-1-\infty$ & $-1-5$ \\
\hline Nadion $1-A 11$ & $\begin{array}{l}\text { 1954 Prime Contract } \\
\text { By 2ot. } 1308 / 1091\end{array}$ & $3 / 23 / 56$ & $5 / 15 / 56$ & 25,000 & $6 / 20 / 56,8$ Shests & $\begin{array}{l}\text { Det. So118, Salts, } \\
\text { proingge. }\end{array}$ \\
\hline Ser2! & Sup.Contr 0420,12 & Jนทีอ, 1954 & $\begin{array}{l}\text { Sol19 } 8 / 54 \\
\text { Drainego } 12 / 54\end{array}$ & 105,000 & Fob. 1955,9 Sheots & $\begin{array}{l}\text { Doto Solls of Valloy } \\
\text { Rocon. Desert portion }\end{array}$ \\
\hline Serej & 1954 Prine Contract & $5 / 18 / 56$ & $8 / 23 / 56$ & 60,000 & Fob. $195 ?, 9$ & $\begin{array}{l}\text { Det. Solla \& Drainage } \\
\text { (Desert) }\end{array}$ \\
\hline Shamajan & Sup.Gontre 10,11 & $\begin{array}{l}\text { Oct. } 1953 \\
\text { Aug. } 1954\end{array}$ & $\begin{array}{l}\text { Solis } 9 / 54 \\
\text { Dreinge } 12 / 54\end{array}$ & 65,000 & Aps: $1956, ?$ & Doto Solls, Drainaese \\
\hline Tarnak & Sup.Contro $1 / 10$ & $\frac{12 / 53}{1 / 56}$ or & $\begin{array}{l}\text { Solis } 5 / 55 \\
\text { Drelnage } 8 / 54\end{array}$ & 110.655 & Nov. 1955,10 " & $\begin{array}{l}\text { Det. So13. \& Deto } \\
\text { Recone Drainage }\end{array}$ \\
\hline Taxnak & 1954 Prine Contrect & $\begin{array}{ll}\text { Jan. } 2956 \\
\text { Oet. } 1956 \\
\end{array}$ & $\begin{array}{l}\text { Fob. } 1956 \\
\text { Dec. } 1956 \\
\end{array}$ & 25,000 & $\begin{array}{l}1 / 56 \\
\text { (revisions) }\end{array}$ & Det. Sol13 \& Drafnage \\
\hline ALL AREAS & $-\infty-\infty$ & $10 / 52-7 / 57$ & -5 & 3.730 .355 & $-5=-5$ & 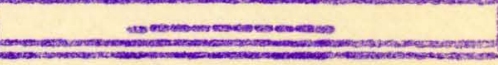 \\
\hline
\end{tabular}

Actual Acres $=1,591,655$ 


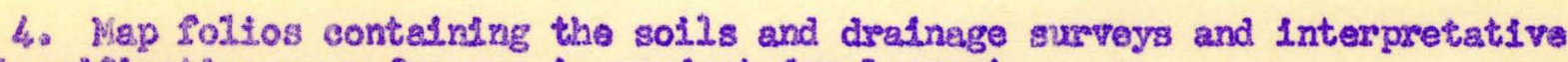
or alessifleation maps for use in project development.

Only the plirgt tิwo w11] be prepared for general distribution The appers dioes and follos w11 bo wetained in a central fllo for seference and only such seprodictions made as axe needer by agencies ongaged in developnent work in a spoctisc axsa. 


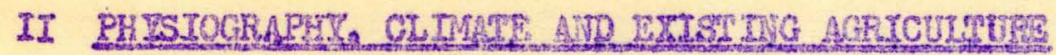

1. Topogsaph end Draingeg:

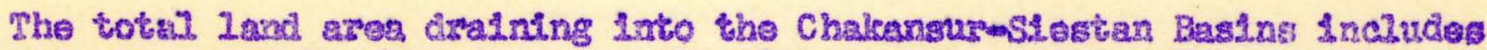
the wetersheds of evarkl mejor gtrems axtending to tho central divide of tho

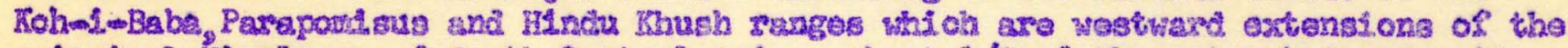

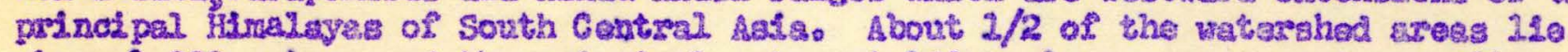

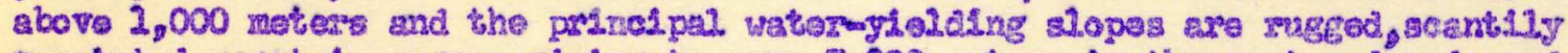

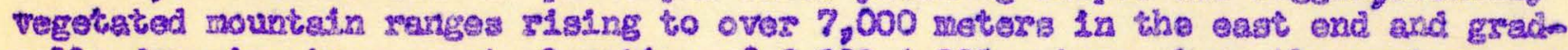

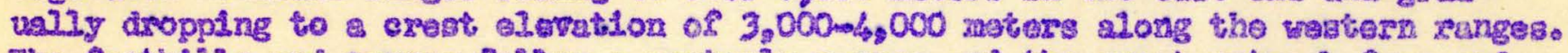

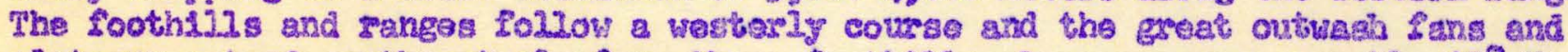

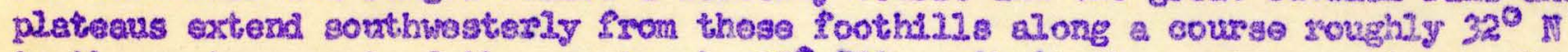

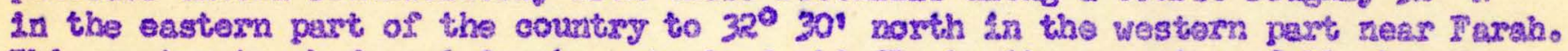

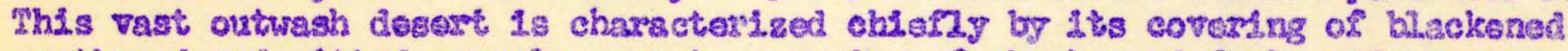
wasthered and pittad greveds, seanty covoring of shrubs and Porbs and grasves, and oceasionel $12 a$ th and stalos coverod with stlts of raxying clepths and more

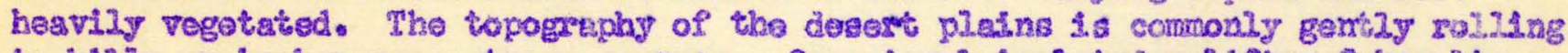

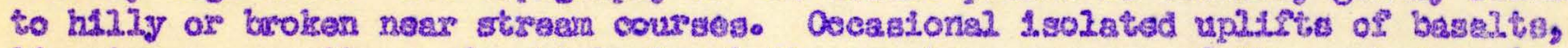

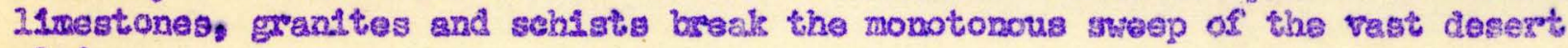
platnas.

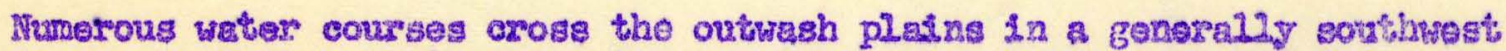
direction. It 1 s ealculated that the combined watershode cover 139,500 squere

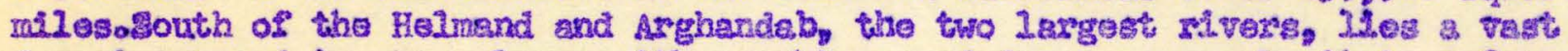

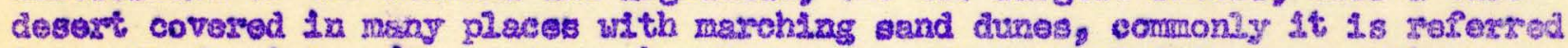

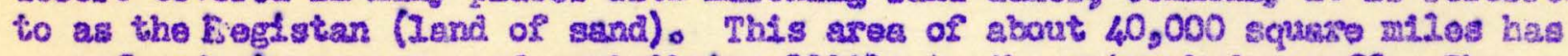
very fow dresinege ways and contributes 1stile to the watershed Irnofi. The lower centrai desert Iylng within the great $100 \mathrm{p}$ of the Helmand called the

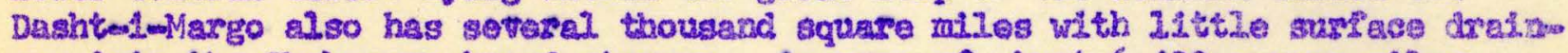

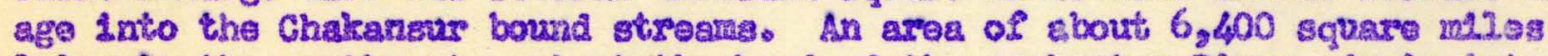
2ydng in the nosthast pawt at the head of the Arghastan Rivor, dralninte in Inland ant basin, Lake Ablstada, which soldon ororflows Lnto the Lower guream

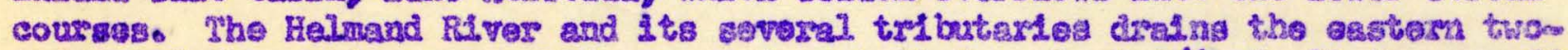
thirds of the entlre waterghed anea and contribute about $5 / 6$ of all the zrunofs.

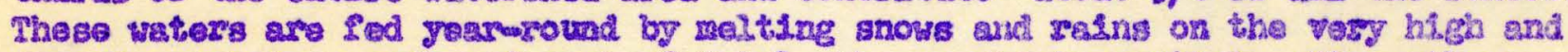
sugged mountalns nothh and wast of Kabal, the country's capttal. Flve other

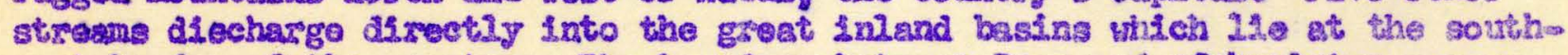
west worder of the conntry. Tho bourdery botweon Irean and Afghersh stan passes

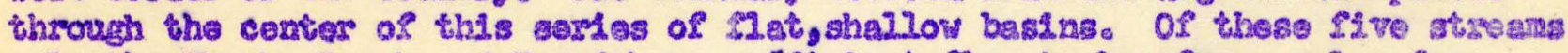
only the Thash. Faxah and Harud havo aufficiant Mon to bo of axy value for

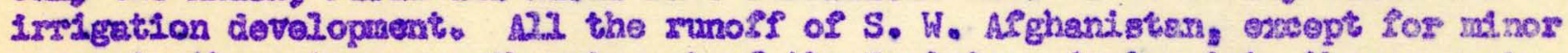

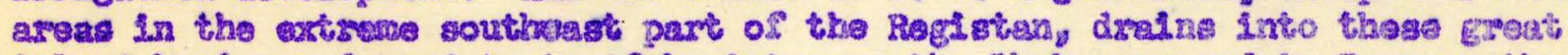

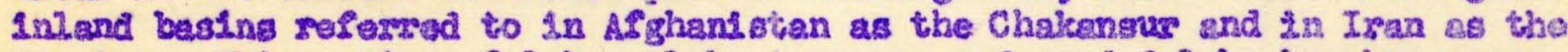

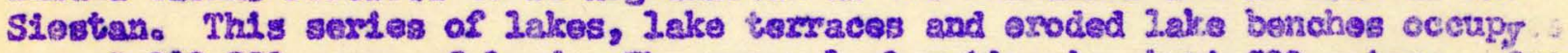

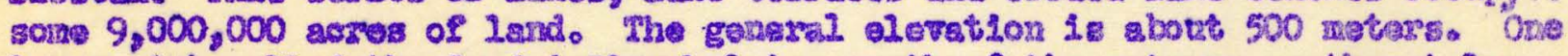

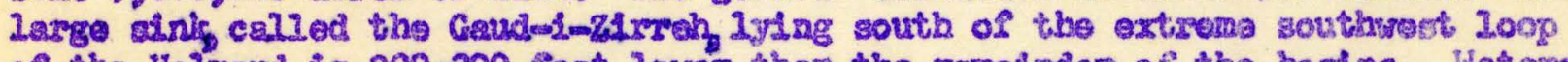
of the Halmand in 200-300 seet lower than the rewalndex of tho bastas Waters

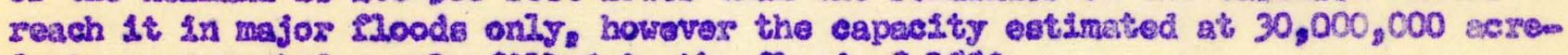
foet was reportod nosuly slied in the nood of 1883.

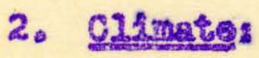

CIImatic records of Iong ducation are almost unknown tn this area. Quitia in Pakistan has the longest records but 18 so sltuated that Ita data 18 relatively inapplicable to the Southwest Afghandetan arsas. The Afghan Møteor 


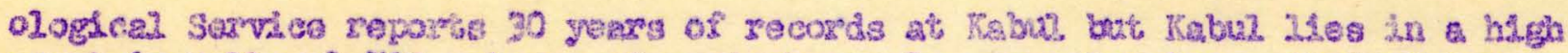

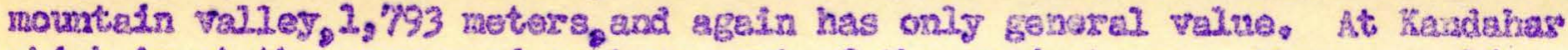

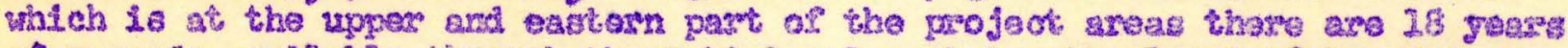

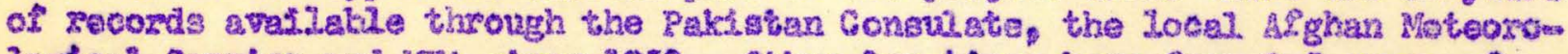

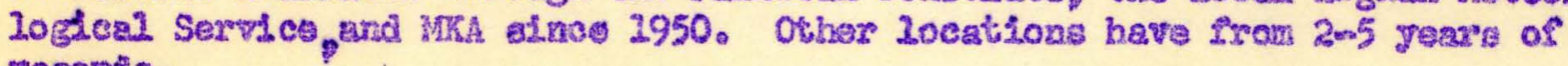
secortis.

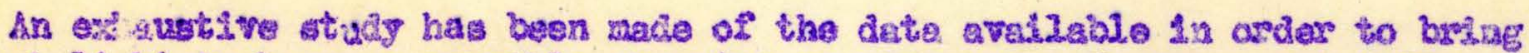

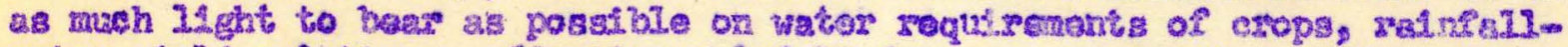

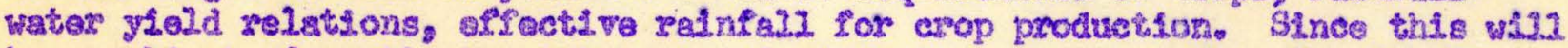
ba a woject of contiming interagt and study the atrmery tablos for the 30 weather stations studiod are included In the appendices to this reporto

Sevorel teblos and charts ropresenting annlyses of the data and the cone clusions dirawn frow thon follow:

\section{B. Lemperature}

Maan nonthly and mean anmal tamperatuxes are plotted fox all yees

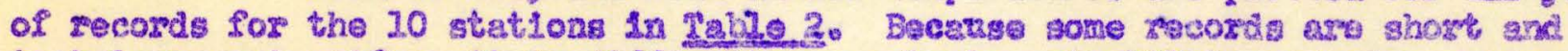

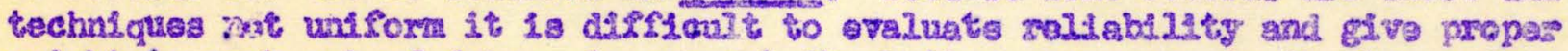
welght to exch wot of data. In gendral tho hotter sreas ase In the lower derertg

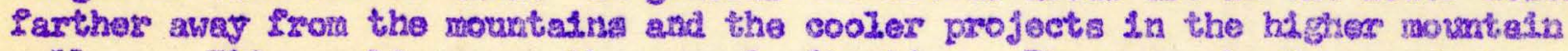

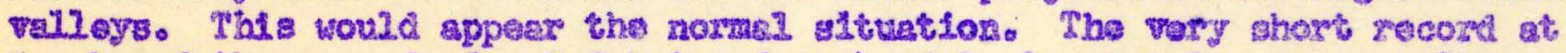

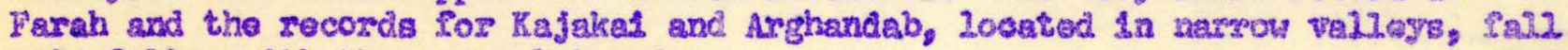
out of lino with the general trend.

Tho mean July tampergturs, the nonth of highest wates uge and, therefore,

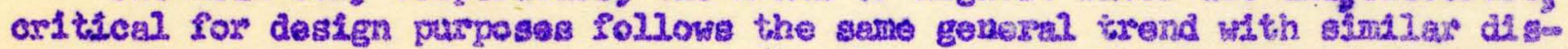
erepencies $2 \mathrm{n}$ oriar of axrangement. For this purpose the July temperature at KaI1 Kang was interyolated as the fon July tecotds war very xuch in disagreow. ment.

The avarege of all projects by monthe and yaere fivas a fels picture of the

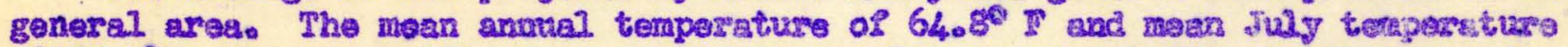

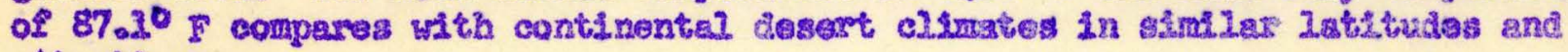
stuatsons.

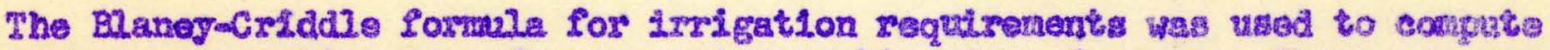
the average congunptsve use of an oxpoctod combination of orops: The mean anmal

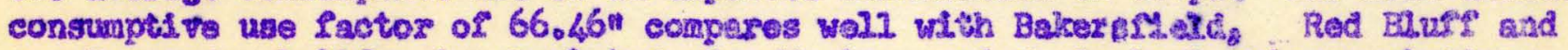

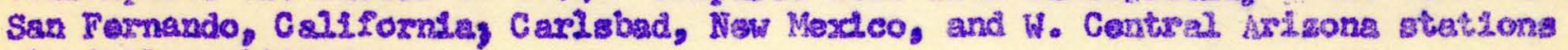
at atmilear altitudes.

Consumptive use of an assuraed avarage combination of exops with an anezrgo

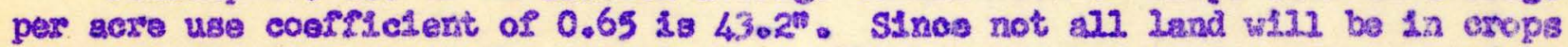
every month of the year the ectual usage will be somowhat lower. The wean JuIy

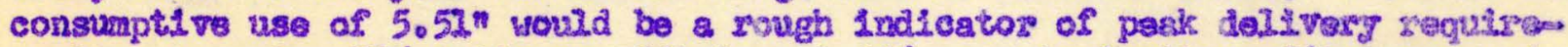

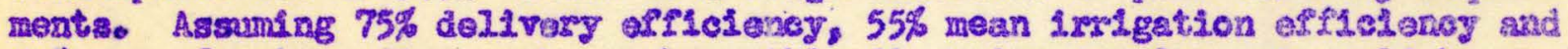

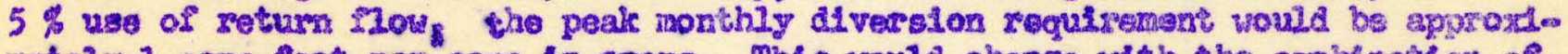
mately 1 nerentoot por acre in cropa. This vould chenge vith the combination of

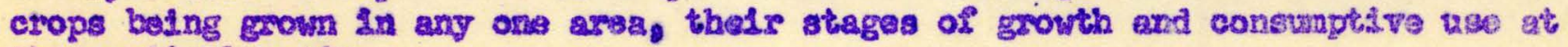
the partieular times 
2 S. W. AFGHANTSTAN CLIMATE

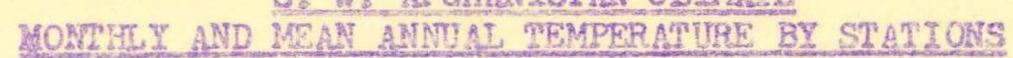

TOCRTYLT: WTTH COMPUTED AVRRAGE EVAPO-TRANSP IRATTON.

(Stations in order of elevetion)

\begin{tabular}{|c|c|c|c|c|c|c|c|c|c|c|c|c|c|c|c|}
\hline 해레 & $\begin{array}{l}\text { 예 } \\
3 \\
3 \\
3 \\
\text { ज्ञ }\end{array}$ & 3) & 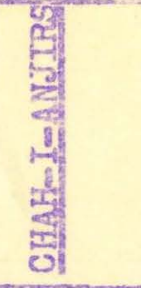 & $\frac{15}{2}$ & 혠 & : & $\begin{array}{l}\text { y. } \\
\text { aी }\end{array}$ & 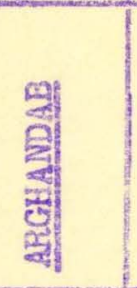 & 这 & 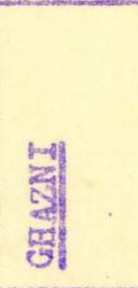 & क्ञा & 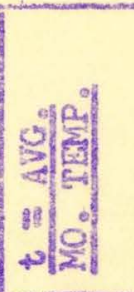 & 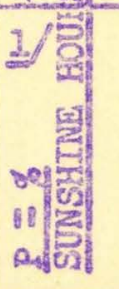 & 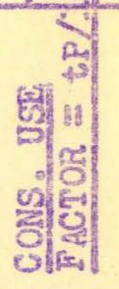 & 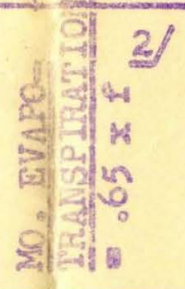 \\
\hline $\mathrm{JAN}$ & 43.7 & 16.2 & 45.8 & 52.3 & 40.6 & 440 & 45.8 & 44.3 & 32,0 & 21.6 & 476.0 & 42.6 & 7.22 & 3000 & 1025 \\
\hline $\mathrm{FEB}$ & 50.9 & 52.9 & 52.1 & 57.8 & 169 & 48.7 & 5204 & 53.61 & 37.3 & 22.6 & 664.8 & 46,5 & 6.99 & 3.25 & 211 \\
\hline MAR: & 58.3 & 6320 & 60.2 & 67.7 & 52.8 & 57.3 & 60.2 & 62,0 & 43.5 & 33.2 & 55822 & 55.8 & 8.32 & 6.67 & $3.6 \mathrm{~m}$ \\
\hline MAY & 83.2 & 81.9 & 83.9 & 82.1 & $7 . ?$ & 75.2 & 80.2 & 78.81 & 65.3 & 58.1 & 761.1 & 76.1 & 9.60 & 7.31 & 4.75 \\
\hline JUN. & 88.8 & 87.8 & 89.2 & 86.8 & 79.0 & 82.1 & 86,6 & 87.9 & 73.8 & 64.6 & 825.6 & 82.6 & 9.57 & 7.90 & 5.14 \\
\hline JU. & $(93.0)$ & 90.9 & 92.2 & 93.7 & 84.8 & 84.7 & 90.2 & 91.11 & 78.3 & 72.4 & 871.3 & 87.1 & 9.74 & 8.48 & 5.51 \\
\hline AIIG & 87.6 & 85.6 & 85.4 & 87.3 & 82.5 & 81.6 & 78.9 & 87.21 & 74.8 & 79.2 & 830.2 & 83.0 & 9.27 & 7.69 & 5.00 \\
\hline SEP. & 77.8 & 78.7 & 77.9 & 77.8 & 73.2 & 72.9 & 75.8 & 80.11 & 66.9 & 63.4 & $74 \leq 65$ & 7404 & 8.34 & 6.20 & 4.03 \\
\hline $0 \%$. & 66.7 & 64.7 & 66.4 & 68.0 & 62.7 & 63.6 & 63.9 & 66.21 & 55.2 & 51.9 & 629.3 & 62.9 & 7.95 & 5.00 & 3.25 \\
\hline Novo & 58.9 & 57.2 & 55.2 & 66.3 & 52.2 & 53.5 & 56.2 & 57.5 & 45.0 & 41.2 & 562.1 & 54.2 & 7.23 & 3.86 & 2.51 \\
\hline$D E C$. & 49.9 & 49.4 & 48.8 & 59.0 & 41.6 & 45.6 & 50.1 & 49.7 & 34.7 & 42.2 & 471.0 & 47.1 & 7.08 & 3.33 & 2.16 \\
\hline rOTALS & 830.9 & 827.3 & 832.8 & 872.6 & 746.6 & 726.0 & 820.0 & 327.5 & 65407 & 296.9 & 7714.0 & 777.4 & $=$ & $\infty$ & a \\
\hline AVG. & 69.2 & 68.9 & 69.4 & 72.4 & 62.3 & 64.6 & 67.5 & 68.9 & 54.6 & 49.7 & $=$ & 64.8 & $-\infty$ & $-\infty$ & $=$ \\
\hline
\end{tabular}

3 Percentage sunshine hours at Latitude $31^{\circ} 30^{\circ} \mathrm{North}$

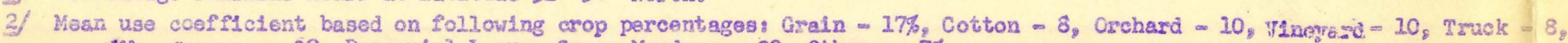

MPscocrops - 20 , Perennial Legume-Grass Meadows -20 , Other $=7 \%$.

Note: Acturi project use would be lower since not all land would be in orops continuously. 


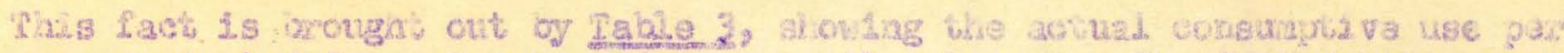
acre evaluatod fox a laxgo project reconty plennede The fama delitrary fom

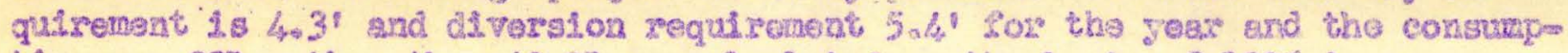
tive uss $33^{n}$ gather than $43.2^{\text {in }}$ a.s calculated on the basis of $100 \%$ in crops all months.

\section{bo Retafe] -}

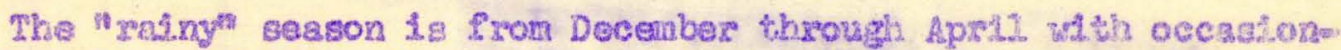
a] showers in November and May. Commonly the sky is clear and the a:ts dxy srom

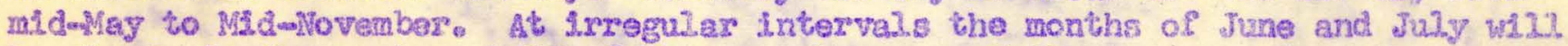
bo loudy in the eastern half of the ares because of the pressure fron the an wow soons of the south central. Asja lowlends. On vory rexe occisions as in July, 2956, the monsoons broal oves the mountain ranges geparating the Indus and Iol, menc watersheds ard heavy ratns fall in the months of June and July on the eastern slopes. Tremendous sheet and gunly arostor was censed by the 2956 zalns and silt 10 ads carried by the straars were of record proportions.

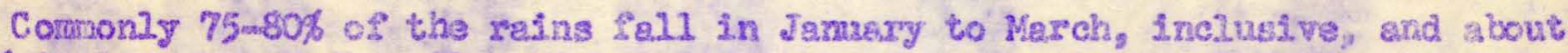

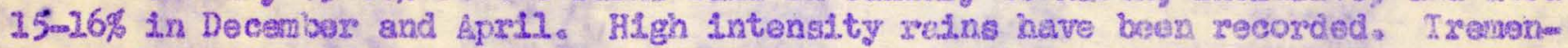
dous shoet flow occurs on the scantily vegetated desert fans which oxtonk long distances out from the segged, barren foothills toward the velleys and atrean channels.

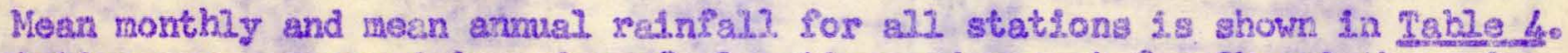
The statlona are axyanged in order of elevation and except for Gham ther" 1 s a faì relationshlp. The range is from 2.8 for the Chakansuz Basin Area at 490 meters elevation to 13.43 for the Kabul Velley si 1,790 meters elevation. The desert projects now belng developed range from $4.81 n$ to $7.29^{m}$ annual. preclptiation. Considering that all of the raing fall in the winter and early spring nonths when temperatures are at their lowest, all ralns over $0.2^{\text {th }}$ are shown as effective in reducling evapo-transpiration or adding to soll molsture. The range is from $3.5^{\mathrm{n}}$ to $5.3^{\text {to }}$ In the project areas being planned.

\section{c. Evaposation -}

Evaporation data, Table 5, was not taken by uniforn mothods and the stumartes and compartsons can only bo sketchy at best. Arranged in ordar of alow vation Marja, Kajakal and Kabul data Rajl to follow tho general. trendo There aro

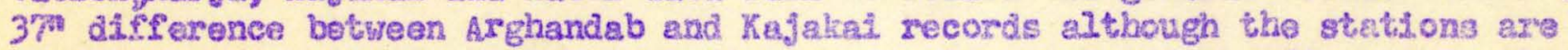
both In naxrow walleys only a fow miles apar' and not greatiy different 1a elos vation. The mean dasily July evaporation $190.455^{\circ}$ which is the mextunum for the yeer and $.06 \%$ in January is the loweat. The Chekensur bestn records skow anma! evaporetion of $125^{\mathrm{m}}$ and Arghandab records show an anmel evaporetion of $6 \mathrm{~h}^{\circ}$.

\section{d. Wind Volocity and Fvaporation Rel gtlonshipe -}

A study of wind velocity, temporature and evs;imeton relationships was made ust.ng the Meyer formula 3/. The data svglible on wind velocit1es Ls givon by stations in $2 a b l e 6$. The extrenely high winds of the chakansux durkng the hot moxths of Juneoseptember are descxibed in th, 1905 Boundexy Comisston report $3 / 9$ also in the Chakansur Soll survey Report $3 /$.

1 Page 168, "Applied Hydrology"t - LLindseyg Rohler \& Paul ns.

$2 /$ Meliuron Report - Afghenjstan-Iran Boundexy Suzvoy 1903 - 05.

3 Report of Chakangur Area So11s \& Dralnage Survoy:, MKA, October, 1955. 
TABLE

AVERAGE EFFECT OF CLIMATE ON IRRIGATION PEOUIREMENTS IN S. W. AFGHANISTAN (Avg. of 10 Stations)

June 23, 1957

\begin{tabular}{|c|c|c|c|c|c|c|c|}
\hline Yonth & $\begin{array}{l}t \quad 1 \\
\text { Mean } \\
\text { Mo. Temp } \\
\text { O. T }\end{array}$ & $\begin{array}{ll}\% & \mathrm{P} \\
\text { Sunshine } \\
\text { Hours }\end{array}$ & $\begin{array}{l}\rho=\frac{t p}{100} \\
\text { Consurnptive } \\
\text { Use Factor } \\
\end{array}$ & $\begin{array}{l}\text { Avg. Ko. } 3 / \\
\text { Cons. Use } \\
\text { E kf } \\
(k=0.65) \\
\text { Inches }\end{array}$ & \begin{tabular}{|l|} 
WeIgnted \\
Cons. Use \\
per acre \\
Including \\
Double-Cropping \\
Inches
\end{tabular} & $\begin{array}{l}\text { rrasm } 5 \\
\text { Irr. Req. } \\
\text { @ } 55 \text { of } \\
\text { Eff. } \\
\text { A.F./Acre }\end{array}$ & $\begin{array}{l}\text { Res. 6/ } \\
\text { Release } \\
\text { Req. } \\
\text { ( 80\% } \\
\text { A.F./Acre }\end{array}$ \\
\hline $\operatorname{Tan}$. & 41.6 & 7.22 & 3.00 & 1.95 & 1.00 & none & none \\
\hline reb. & 46.5 & 6.99 & 3.25 & 2.11 & 1.25 & 0.04 & 0.05 \\
\hline Mar. & 55.8 & 8.37 & 4.67 & 3.04 & 2.25 & 0.14 & 0.18 \\
\hline has. & 66.0 & 8.74 & 5.77 & 3.75 & 3.50 & 0.45 & 0.55 \\
\hline May & 76.1 & 9.60 & 7.31 & 4.75 & 4.75 & 0.69 & 0.85 \\
\hline Jun. & 82.6 & 9.57 & 7.90 & 5.14 & 4.00 & 0.61 & 0.75 \\
\hline Sul. & 87.1 & 9.74 & 8.48 & 5.51 & 5.50 & 0.83 & 1.05 \\
\hline Auge & 83.0 & 9.27 & 7.69 & 5.00 & 4.00 & 0.61 & 0.75 \\
\hline $\mathrm{Sep}_{2}$ & 74.4 & 8.34 & 6.20 & 4.03 & 3.00 & 0.45 & 0.55 \\
\hline bet. & 62.9 & 7.95 & 5.00 & 3.25 & 1.25 & 0.19 & 0.24 \\
\hline Nor. & 54.2 & 7.23 & 3.86 & 2.51 & 1.50 & 0.20 & 0.25 \\
\hline Dec. & 47.1 & 7.08 & 3.33 & 2.16 & 1.00 & 0.10 & 0.13 \\
\hline Cotals & 777.4 & - & - & $43.20^{n}$ & $33.00^{n}$ & 4.301 & 5.401 \\
\hline leans & 64.8 & $=$ & - & $3.60^{m}$ & $2.75^{\circ}$ & 0.361 & 0.451 \\
\hline
\end{tabular}

Eootnotes:

1) Data from 10 stations, elevations; 540-2240 meters; 3-44 years records.

2) Sunshine hours at $31^{\circ} 30^{\prime} \mathrm{N}$. Latitude.

3/ Average $k$ of .65 used for crops grown in the area.

4) This represents mean per acre consumptive use based on $\%$ of land in various crops and stage of growth. Includes double cropping.

5/ Cons. Use - rainfall +.55 = farm irrigation req. at avg. assumed efficiency。

6f Delivery losses are $75 \%$, return flow usage $=5 \%$ 
TABLE

4

S. W. AFCHANTSTANI CLIMATE *

Blevation in Meters:

MEAN ANNUAL RATIFAILI

\begin{tabular}{|c|c|c|c|c|c|c|c|c|c|c|c|c|}
\hline :ONTHS & $\begin{array}{l}490 \\
\text { Chakansux }\end{array}$ & $\begin{array}{l}780 \\
\text { Marja }\end{array}$ & $\begin{array}{l}790 \\
\text { Chah-i.-Anjirs }\end{array}$ & $\begin{array}{l}\text { 884h } \\
\text { Fareh }\end{array}$ & $\begin{array}{l}923 \\
\text { Herat }\end{array}$ & $\begin{array}{l}1000 \\
\text { Kandahar }\end{array}$ & $\begin{array}{l}1030 \\
\text { Ka jakas }\end{array}$ & $\begin{array}{l}1110 \\
\text { Arghandab }\end{array}$ & $\begin{array}{l}1793 \\
\text { Kabus }\end{array}$ & $\begin{array}{l}221,1 \\
\text { Chaznd }\end{array}$ & TOTALS & NEANS \\
\hline JANUARY & 1.0 & 3.69 & 1.24 .12 & 1.04 & 2.44 & 2.49 & 1.44 & 2.43 & 1.21 & 1.63 & 16.61 & 3.67 \\
\hline FRBRUARY & .8 & 0.72 & 1.25 & 0.92 & 1.31 & 1.73 & 1.38 & 1.86 & 1.43 & 1.60 & 12.99 & $\frac{200}{1.30}$ \\
\hline ARCH & .6 & 1.43 & 1.53 & 0.41 & 1.52 & 3.43 & 2.88 & 2.94 & 4.05 & 2.07 & 17.84 & 3.78 \\
\hline APRII & .2 & 0.24 & 0.20 & 0.04 & 0.34 & 0.48 & .57 & 0.51 & 3.67 & 0.85 & 7.10 & 0.72 \\
\hline $\operatorname{AnY}$ & & 0.02 & 0.16 & 0.05 & 0.17 & 0.22 & .11 & 0.23 & .78 & 1.06 & 2.80 & 0,28 \\
\hline TONE & 0.0 & 0.00 & 0.15 & 0.00 & 0.00 & $\mathrm{~T}$ & $\mathrm{~T}$ & $T$ & .27 & 0.36 & 0.75 & 0.08 \\
\hline 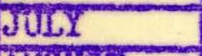 & $T$ & $T$ & 0.20 & 0.00 & 0.00 & 0.24 & .114 & $(.34)$ &. .13 & 0.44 & 1.23 & 0.12 \\
\hline UUGUST & 0.0 & 0.00 & 0 & 0.00 & 0.00 & $\frac{\pi}{2}$ & 0 & 0 & .34 & 0.08 & 0.23 & 0.02 \\
\hline FPTTMBER & 0.0 & 10.00 & 0 & 0.00 & 0.00 & 0 & 0 & 0 & $\frac{\pi}{3}$ & 0.09 & 0.10 & 0.01 \\
\hline CTOBER & 0.0 & 10.01 & 0.04 & 0.00 & $T$ & .02 & .02 & 7 & .56 & 0.00 & 0.67 & 0.07 \\
\hline OOVEABER & 2 & 0.04 & 5 & 0.59 & 0.31 & .044 & .02 & .01 & .82 & 0.08 & 1.93 & 0.20 \\
\hline ECFA3BER & .25 & 10.73 & 0.56 & 1.57 & 2.33 & .74 & 1.16 & 3.57 & .043 & 0.49 & 8.83 & 0.88 \\
\hline OTALS & 2.85 & 4.81 & 5.33 & 4.63 & 7.43 & 7.29 & 7.72 & 8.69 & 13.43 & 8.75 & 7.06 & 7.21 \\
\hline $\begin{array}{l}\text { BTENTALI. } \\
\text { BATES }\end{array}$ & 2,00 & 13.50 & 3.75 & 3.40 & 5.45 & 5.30 & 5.55 & 6.40 & 9.85 & 6.35 & 52.55 & 5.15 \\
\hline $\begin{array}{l}\text { EARS OF } \\
\text { EACORD }\end{array}$ & 5 (partia) & 4 & 6 & 3 & s. & 29 & 6 & 6 & 44 & 4 & (103) & - \\
\hline
\end{tabular}

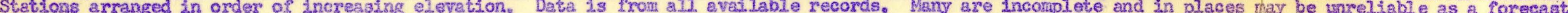

* An average of $75 \%$ of the rains are above .20 and may be considered effective in supplying solI moisture or reducing trunspiration-evaporation losses. 
$2 A B P=5$

CLTMATE - FERE WATER EVAPORATION FROM SUREACE IANS

July 7,1957

\section{Inchas}

\begin{tabular}{|c|c|c|c|c|c|c|c|c|c|c|}
\hline Month & $\begin{array}{l}\text { Esto } \\
\text { citrus } \\
\text { Cons. } \\
\text { Use }\end{array}$ & $\begin{array}{l}\text { Chakan- } \\
\text { sux }\end{array}$ & tarefa & $\begin{array}{l}\text { Lashkar- } \\
\text { gah }\end{array}$ & $\begin{array}{l}\text { Chahow } \\
\text { Les } \\
\text { Anfires }\end{array}$ & $\begin{array}{l}\text { Randa- } \\
\text { har }\end{array}$ & $\begin{array}{l}\text { Kajam- } \\
\text { kat }\end{array}$ & $\begin{array}{l}\text { Arghan } \\
\text { dab }\end{array}$ & Kaby? & Avera \\
\hline Jan..... & 0.2 & 2.67 & 2.52 & 2.48 & 1.87 & 1.72 & $2 \ln 23$ & 2.23 & 26.89 & 2006 \\
\hline & 1.00 & 3.56 & 4688 & 3.59 & 2.54 & 2.57 & 3.31 & 1.76 & 207 & \\
\hline Mar & 1.55 & 455 & 6.77 & 6.12 & 4009 & 3.87 & 3.94 & 3.18 & & 4.63 \\
\hline Der & 2.50 & 6.93 & 7.92 & 9.56 & 7.57 & 6.53 & 8.00 & 6.00 & & 7.40 \\
\hline & 3.75 & 21,29 & 15.07 & 15.36 & 70.65 & 900 & 12.95 & 7.26 & 9.05 & 7131 \\
\hline$m_{8}$ & 4620 & 12.05 & 25.66 & 9.19 & 12.63 & 10.07 & 15.26 & 8.60 & 12.97 & 12.62 \\
\hline & 4.75 & 20.49 & 78.28 & 13.42 & 32.51 & 10.25 & 15.45 & 8.58 & 35.59 & 34.93 \\
\hline Ifg. & 4.15 & 26.19 & 17.24 & 20.47 & 12.07 & 10.24 & 34.27 & 8.47 & 11.81 & 12044 \\
\hline & 3.25 & 12.63 & 10.94 & 7.19 & 8.36 & -7.53 & 13.28 & 6.42 & 21.96 & 9.52 \\
\hline & 2.20 & 8.53 & 8,01 & 3,80 & 4.82 & 5.22 & 7887 & 5.44 & 6.87 & 6.30 \\
\hline & 1.45 & 5.49 & 6.53 & 3.18 & & 3.12 & 4041 & 3.63 & 4.60 & 4,30 \\
\hline & 1.25 & 3.74 & 3,73 & 1.99 & $22^{2}$ & 2.90 & 3.27 & 2.37 & 2.26 & 2.67 \\
\hline RALS & 30.55 & 115.05 & 717.43 & 84.35 & 81.67 & 72.52 & 201,78 & 63.82 & $\frac{90,70}{7.35}$ & $\frac{90,47}{7.63}$ \\
\hline
\end{tabular}

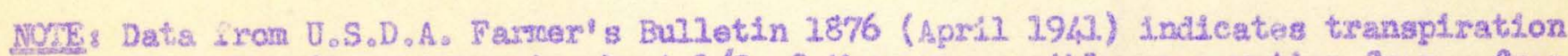
use by eitrus trees is about $3 / 3$ of the mean monthly evaporation from a free water surface. 
2able 6

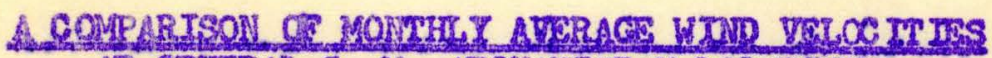

$8 / 22 / 57$

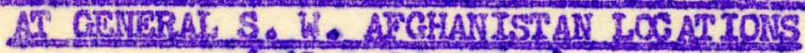

(MIIs: Por Hous)

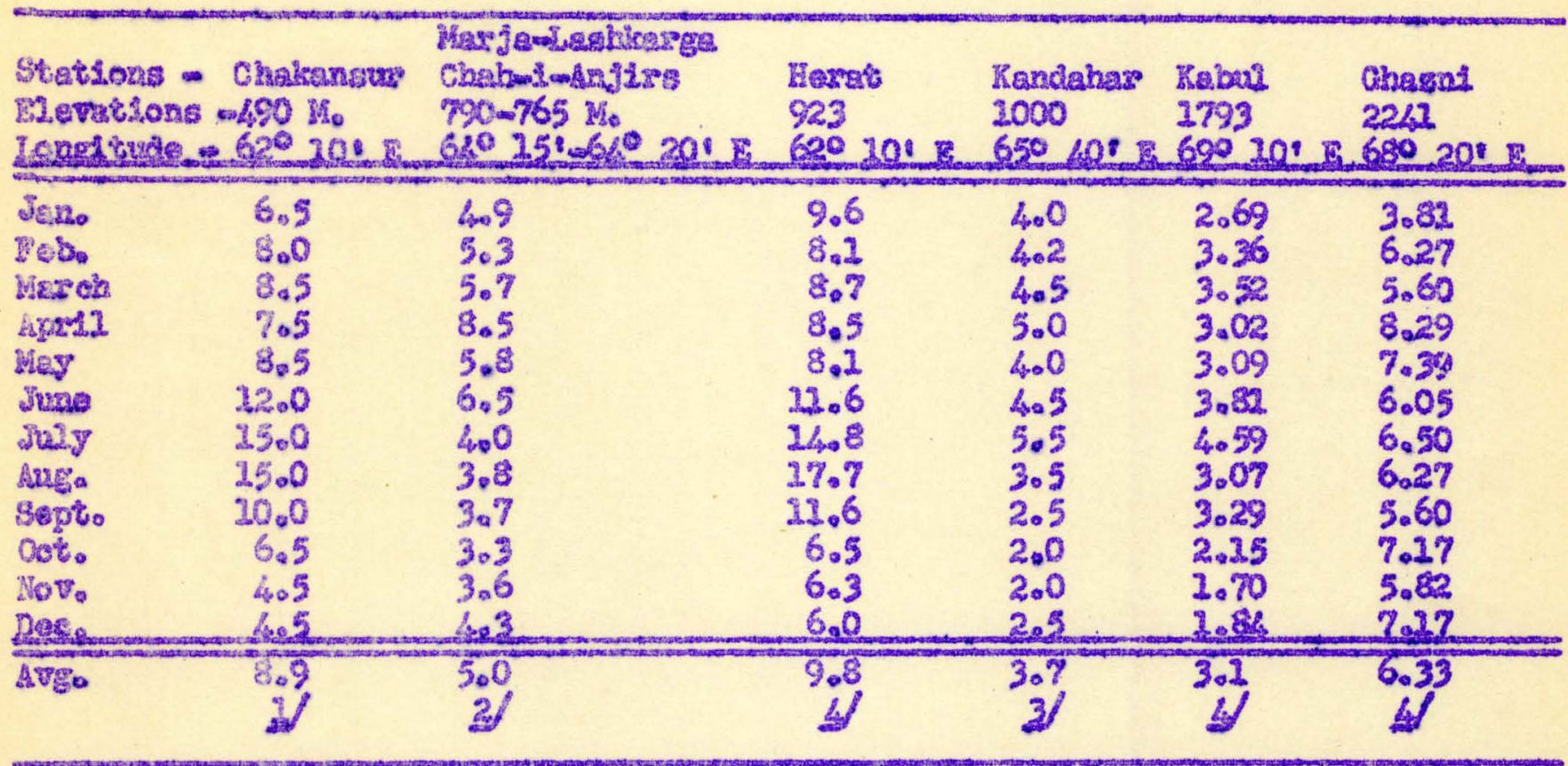

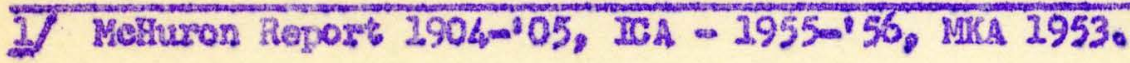

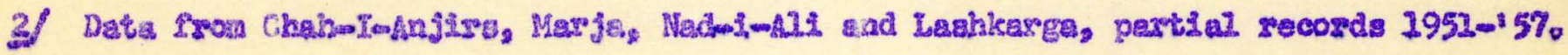

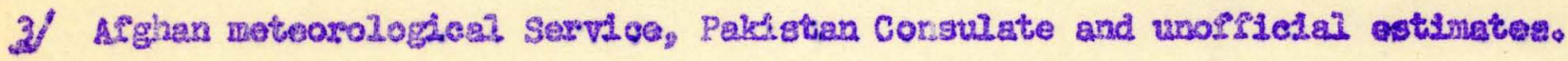

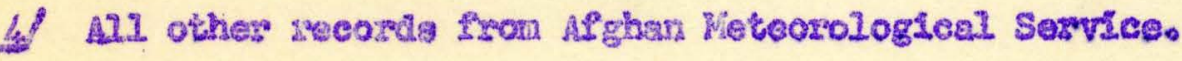


4. Map Lotios contalnirg the soils and dreinage surveys and interpretative

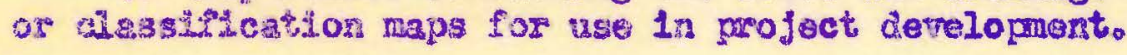

Only the I1xst two will ba prepared for general distributox The apperw ditoes and follos wil be tetolnat in a central flle for teierence and only such reproductione made as axe noeded by agencies ongaged in deyelopuent wors $1 \mathrm{n}$ a 3pocidic arsa. 


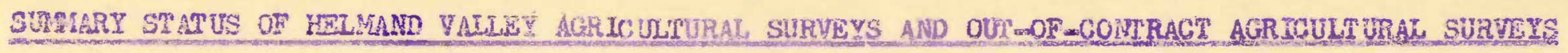

\begin{tabular}{|c|c|c|c|c|c|c|}
\hline ADEEA & AUTYORYFY & $\begin{array}{l}\text { PEID } \\
\text { WORK ERGAN }\end{array}$ & $\begin{array}{l}\text { FTELD WORK } \\
\text { COMLLETED }\end{array}$ & $\begin{array}{l}\text { GROSS ABHES } \\
\text { SURVEYED }\end{array}$ & $\begin{array}{l}\text { FINAL VIAPS } \\
\text { DRALAED }\end{array}$ & TYPE OR SUPVEX \\
\hline Arghandab, No & Sun Conts un 10,11 & March 1953 & Auge 3953 & 67.635 & $11 / 8 / 53.6$ Shegts & Deterecon Seilg Draín. \\
\hline Axghandab, $S$ & 1954 Prime Contract & June, 1955 & $\begin{array}{l}\text { Solis } 12 / 55 \\
\text { Drealn } 2 / 56\end{array}$ & 132.220 & $1 / 17 / 56_{8} 10$ & $\begin{array}{l}\text { Det. Soils, Deto Recon } \\
\text { of Dreinege }\end{array}$ \\
\hline Besixa & $17.0,438$ & $\begin{array}{l}12 / 55 \\
2 / 5 / 57\end{array}$ & $(5 u d y \cdot 57)$ & 275,000 & Not Begur & $\begin{array}{l}\text { Det. Rocono - Solig \& } \\
\text { Drainage }\end{array}$ \\
\hline Cbakansur & W. O. 1129 & Not: 1954 & $\mathrm{Mlg}_{2} 1955$ & 554,335 & $\begin{array}{l}1 / 54-4 / 55 \\
34 \text { Sheets }\end{array}$ & $\begin{array}{l}\text { Deto Recent - So11a } \\
\text { Dratnage }\end{array}$ \\
\hline Darwe Shar? & Sup.controtion 11 & A4E. 1954 & Det 1956 & 73.10 & $9 / 27 / 55,9$ Sheaxs & $\begin{array}{l}\text { Det. Solls, Det. Recona } \\
\text { Doginage }\end{array}$ \\
\hline Daxwashan & 1956 Prime Contract & June: 1956 & Dee. 7956 & 12,500 & $3 / 13 / 57, ?$ & $\begin{array}{l}\text { Solis \& Dof. Dralngge } \\
\text { Selected Arogs }\end{array}$ \\
\hline Fasah & W. 0.438 & Not Begun & - & $=-$ & - & \\
\hline Garnso 1 & 13.0 .439 & $A D 5^{\circ} \cdot 2955^{\circ}$ & Mav, 1955 & 123,800 & $8 / 5711$ shostr & Rocon of Solls \\
\hline Kajskai Wo & Intter of forvart & Hov. 1955 & Nov. $\quad 3955$ & 32.800 & $12 / 17 / 55,1$ sheat & Det. Recon sol18 \& Dr \\
\hline Khash & K. O. if 38 & Not Bogun & - smeses & semen. & 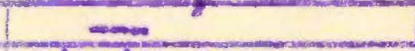 & $-\infty$ \\
\hline Narje & S2an Contr. 110,11 & $10 / 5 / 62$ & $2 / 53$ & 45.000 & $5 / 23 / 53.2$ Shosts & Det. Racon So118 \& Dro \\
\hline Mar ja & $\begin{array}{l}\text { W.O.f } 5, \text { Lettars } \\
\text { ACUP-3-40, } 50,54\end{array}$ & $10 / 24 / 56$ & $5 / 25 / 57$ & 35,000 & $\begin{array}{l}11 / 1 / 56-8 / 57_{8} \\
55 \text { Shoots }\end{array}$ & $\begin{array}{l}\text { V. Det. Solls Survey } \\
\text { inoLo draliab13ity }\end{array}$ \\
\hline Yusa Kala & W.O." 38 by Lettor I & Not Begun & $=$ & -- & - Dasien & -5 \\
\hline Nad $=9=A 11$ & $\begin{array}{l}\text { 1954. Prime Contract } \\
\text { By 20t. } 1308 / 1091\end{array}$ & $3 / 13 / 56$ & $5 / 15 / 56$ & 25,000 & $6 / 20 / 56,8$ shests & $\begin{array}{l}\text { Des. 50118. 5al6s } \\
\text { proinage }\end{array}$ \\
\hline Seraj & Supoconte oth20, 11 & June, 1954 & $\begin{array}{l}\text { So11: } 8 / 54 \\
\text { Drainege } 12 / 54\end{array}$ & 100,000 & Feb. 1955,9 Shoets & $\begin{array}{l}\text { Doto Solls of Vellay } \\
\text { Recon Desert partion }\end{array}$ \\
\hline Sersi & 2954 Prige Cortract & $5 / 28 / 56$ & $8 / 23 / 56$ & 60,000 & Feb. 1957,9 & $\begin{array}{l}\text { Det. So11s \& Dranage } \\
\text { (Desert) }\end{array}$ \\
\hline Shamalan & Sug.Gontre 10,11 & $\begin{array}{l}\text { Oeto } 1953 \\
\text { Aug. } 2954\end{array}$ & $\begin{array}{l}\text { Solis } 9 / 54 \\
\text { Drairage } 12 / 54\end{array}$ & 65,000 & Apse $.954, ?$ & Dot. Solls, Dratnegs \\
\hline Tarnak & Sip.Conts. H10 & $\begin{array}{l}11 / 53 \text { or } \\
1 / 54\end{array}$ & $\begin{array}{l}\text { Solls } 5 / 55 \\
\text { Drginse } 8 / 54\end{array}$ & $110_{2} 655$ & Nov, $1955,10 \%$ & $\begin{array}{l}\text { Det. SoL1. \& Deto } \\
\text { Recon. DreInege }\end{array}$ \\
\hline T exrnak & 2954 Frine Contract & $\begin{array}{l}\text { Jan. } 2956 \\
\text { Det. } 1956 \\
\end{array}$ & $\begin{array}{l}\text { Pob. } 1956 \\
\text { Dec. } 1956 \\
\end{array}$ & $25_{2} 000$ & $\begin{array}{l}1 / 56 \\
\text { (rovisions) }\end{array}$ & Det. Solig \& Ixadrags \\
\hline ALL AREAS & $-\infty-\infty-5-$ & $10 / 52-7 / 57$ & 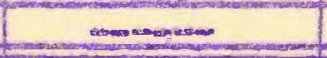 & $1,730,155^{5}$ & $-2-m-\infty-\infty-\infty$ & 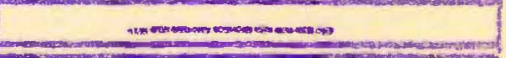 \\
\hline
\end{tabular}

* Actual Acrea 1,591,655 


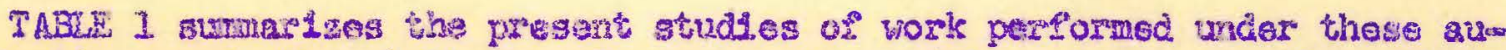
thor zations and other lettors and egreenents on flie. A more complete 1 ist of

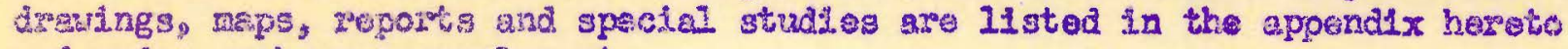
and undor aech area supplement.

\section{Puxpoge of Burgeya and Ronorts}

Bxiefly statod, the solls and areinablity surveys, raps and reports, are s compilation of detaliod obssrvations, neasurements and ensiyges of tho land

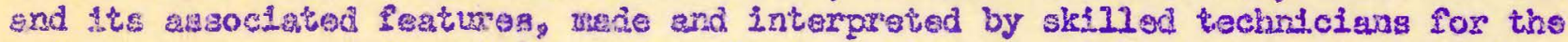
primaxy purposs or describling and ovaluating the potential use and productivity of a percel of land and the poblews inherant uth tis devolophent and use.

Sunmatined thon the rarious contracts and woxt oxders listed ebove the apectes If purposas of the Halmand Valley survays aro to deterino:

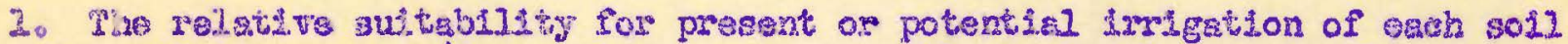

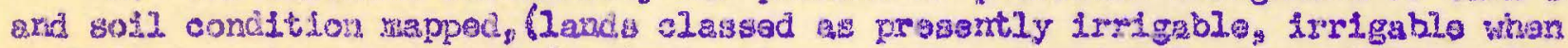

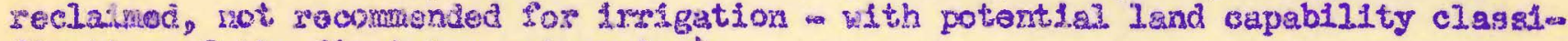
Pication of the Plsot two carogortes):

2. The lestis snd relative degreen of Intensity of problens to bo overeone

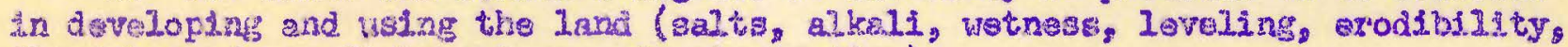
lood hazaris, soll behaviour undar Inrigation)

3. The bast aufted cxops and sequences of crops for each major greup of 30112 and soll conditions:

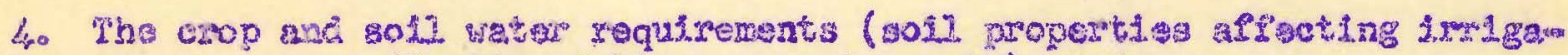
tion Lavout, erop use affecting delivary recisiremons) and,

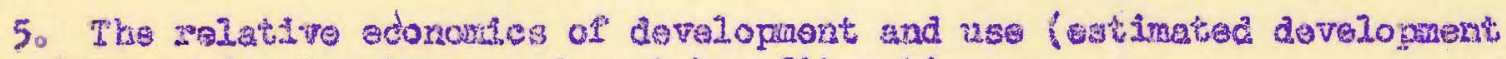
costs, grow and agt xetuma and costomenost rationo

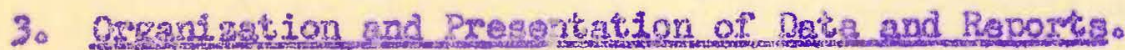

Becsuas of the volune of data in the form of mapg, tables, log: $1 \mathrm{t}$ inas betn fornd fupractiogl. to condenoe all this material into gummary reports. Much of the date such as pit logs and luboratory anelyses will bo congtanty referad to as levelopneat puogres33s into each eres. To facijitate the use of workjug dats es well as af ford a usible bxiaf report on each projoct the Helnand valley Agriculturel. Surreys ase arrangor as foliows:

2. Gomera? Heportso

2. Supplenentil poporta by axws.

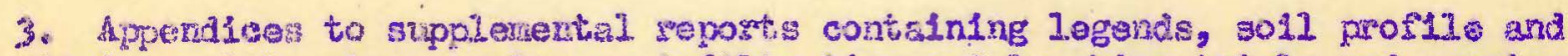
deep pit Loge, laboratory aniyses, infiltration and iesching trials and previous prelinfinary of lnteran greportio 


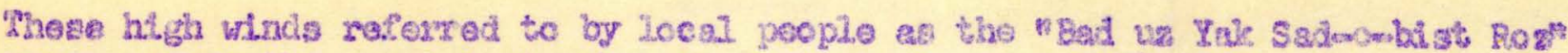

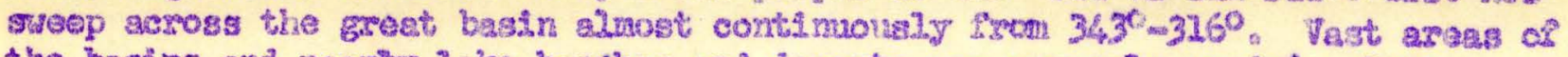
the bastins and nearly lake benchos and desorts are severoly excoded. cver 200,000 acres of masching dunes have accumulsted In the southeast paxt of the

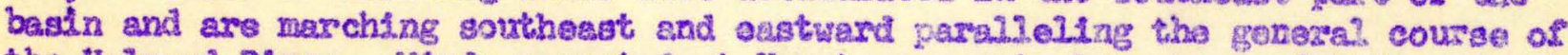
the Helmand River. Winds roported at Heret appear to be a part of this gonoral pattern. Data from tho more easteri.y deserts and the higher paileys do not show these high sunmer winds, however".

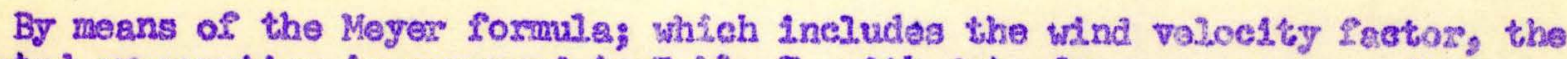

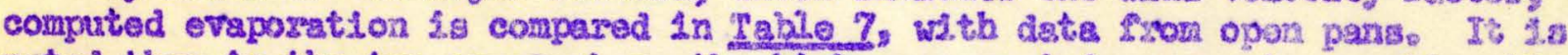
noted than in the two areas whore the high sumner winds axo not so notzeesblo tho neasured and computed ovaporation compare Irigly woll. The Chalrangur dats sows

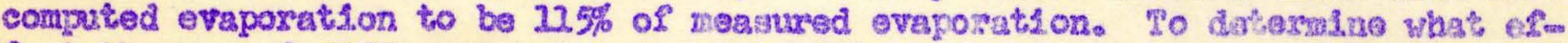
fect the ues of dLfissences In wind valocities and actual or computed evaposetion might have on estimgtes of water consumption a conparison of these mothods Lis made In Tabie 8, Here three apgroaches are compared. Basieally, the study of Aaghan.

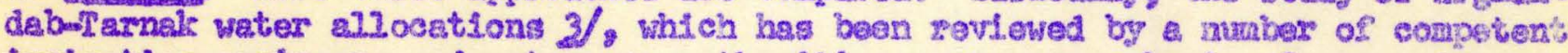
Irrigation exglnoers and water use authoritLes sertos as a besis of gomparison.

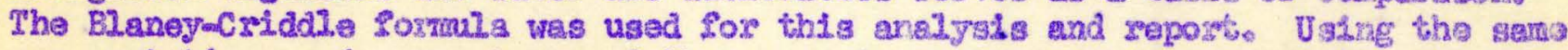
crop rotatidons and percentages of the areas in vachous azops a conpartson is mads

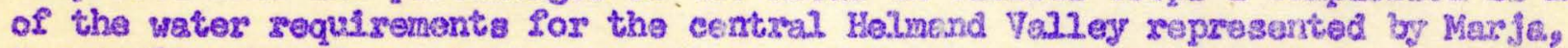

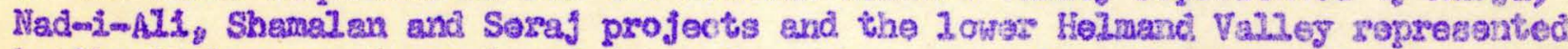
by the Chakangux, Gaxtagel and Iower Darweshan projects. The Darweshan is shown separately. Tho Ilrst comparison assunes that the wator use racruirenents of the other desert projects are proportional to the moasured evaporgtion at Kancelnes and at the projects studied. Computed to divergion requirements par acre at $55 \%$ farn Irrigation efficioncy and $75 \%$ dolivery efriclency with $5 \%$ return flow usege, this conparison gives as diversion requirements Kandehar-4.3 acremiegt, central. Heirand

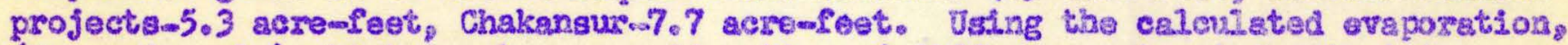
(Meyer formula) whtch Lnvulve consideration of difforences in wind voloclites 3

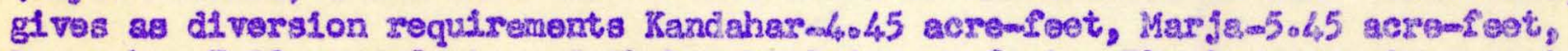

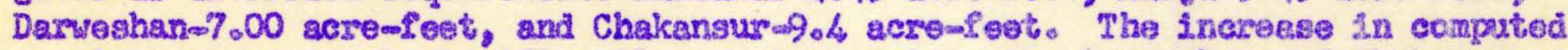
requirements are not slgnificantly great axcept in the Daxweshan and Chakensur areas. The Blaney-Criddlo Method which considerg generally the relation of moan monthly tenperature and sunshine hours gives:Kandahar o. 3 feet, Nax jando 8 feet,

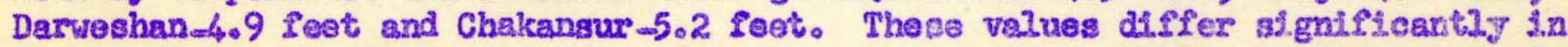
the Darweshan and Chakansur areas from the above velues which conetdered ths high sumes: winds and high ovaporation rates. In Chapter VII these differences in climatic characteriatics are given consideration in water roguirenent gtudies.

\section{- Groving Season and Range of Crop Adputation m}

Kanciaher has an everage of 264 frost Ireo deys with a recorded rangs of 245 to 285 days with no temperatures below $32^{\circ}$. No single 24 - Nour day of recort has been bolow $32^{\circ}$ for the sull 24 howrs. Conerelly these 1 . ow toraperatures last only few hours and the days are in the $40 \mathrm{n} 60$ degree zange. The aresage daily maximum ranges Srom $44^{\circ}-67^{\circ}$ Ior Jamuary and $48^{\circ}-73^{\circ}$ Sor December, tho cold

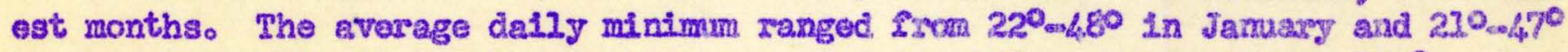
In Decerber. The 1owest temperature recorded was $12^{\circ}$ and the highsst $112^{\circ}$. January averaged 17 days and December 15 days when the temperatures resched $32^{\circ}$ os 1 egs. 


\begin{tabular}{|c|c|c|c|c|c|c|c|c|c|c|c|c|c|c|c|}
\hline & \multicolumn{5}{|c|}{ CHAKANSUR APIEA } & \multicolumn{5}{|c|}{ MARJA-LASIKARGA-GHAH - J=ANIIRS } & \multicolumn{5}{|c|}{ KANDAHAR PRG } \\
\hline Mogth & $\begin{array}{l}\text { Mean } \\
\text { Moo } \\
\text { Tempo } \\
\text { go }\end{array}$ & $\begin{array}{l}\text { I } \\
\text { Rel. } \\
\text { Pund - } \\
\text { dity }\end{array}$ & $\begin{array}{l}\text { WLnd } \\
\text { Vel. } \\
\text { M.P.H. }\end{array}$ & $\begin{array}{l}\text { Evapo: } \\
\text { ation } \\
\text { Calco in } \\
\text { ches.2/ }\end{array}$ & $\begin{array}{l}\text { Evepor } \\
\text { ation } \\
\text { Measo } \\
\text { Inches }\end{array}$ & $\begin{array}{l}\text { Mean } \\
\text { Moo } \\
\text { Tempo } \\
\text { go }\end{array}$ & $\begin{array}{l}\text { s } \\
\text { Rel. } \\
\text { Huwi- } \\
\text { dLty. }\end{array}$ & $\begin{array}{l}\text { Wiad } \\
\text { Valo } \\
\text { M.P.H. }\end{array}$ & $\begin{array}{l}\text { Evapoy- } \\
\text { atjon } \\
\text { Calc. In } \\
\text { chas }\end{array}$ & $\begin{array}{l}\text { Fapor } \\
\text { ation } \\
\text { Iars. } \\
\text { Inchos. }\end{array}$ & $\begin{array}{l}\text { Mean } \\
\text { Mo. } \\
\text { Temp. } \\
\text { no }\end{array}$ & $\begin{array}{l}\text { R } \\
\text { Rol. } \\
\text { humi- } \\
\text { disy }\end{array}$ & $\begin{array}{l}\text { WLind } \\
\text { Yel. } \\
\text { M.P. B. }\end{array}$ & $\begin{array}{l}\text { Evepor } \\
\text { atson } \\
\text { Cale. } \\
\text { Inches }\end{array}$ & $\begin{array}{l}\text { Evapor } \\
\text { at1on } \\
\text { Moas } \\
\text { Trchos }\end{array}$ \\
\hline $\begin{array}{l}\text { Jan. } \\
\text { Fab. } \\
\text { March } \\
\text { April } \\
\text { May } \\
\text { June } \\
\text { Juzy } \\
\text { Aug. } \\
\text { Sopt. } \\
\text { oet. } \\
\text { Nov. } \\
\text { Dec. }\end{array}$ & $\begin{array}{l}43.7 \\
50.9 \\
58.3 \\
72.2 \\
83.2 \\
88.8 \\
(93.0) \\
87.6 \\
77.8 \\
66.7 \\
58.9 \\
42.9 \\
\end{array}$ & $\begin{array}{l}55 \\
55 \\
50 \\
42 \\
35 \\
30 \\
30 \\
25 \\
27 \\
35 \\
45 \\
55 \\
\end{array}$ & $\begin{array}{r}6.5 \\
8.0 \\
8.5 \\
7.5 \\
8.5 \\
12.0 \\
15.0 \\
15.0 \\
10.0 \\
6.5 \\
4.5 \\
4.5 \\
\end{array}$ & $\begin{array}{r}2.1 \\
3.0 \\
4.5 \\
8.1 \\
13.7 \\
21.1 \\
27.3 \\
25.4 \\
25.1 \\
7.4 \\
4.1 \\
2.3 \\
\end{array}$ & \begin{tabular}{|l}
2.6 \\
3.6 \\
4.5 \\
6.9 \\
11.3 \\
19.0 \\
20.5 \\
16.2 \\
12.6 \\
8.5 \\
5.5 \\
3.7 \\
\end{tabular} & $\begin{array}{l}46 \\
53 \\
63 \\
69 \\
82 \\
88 \\
91 \\
86 \\
79 \\
65 \\
57 \\
49\end{array}$ & $\begin{array}{l}76 \\
54 \\
54 \\
42 \\
35 \\
33 \\
30 \\
31 \\
30 \\
38 \\
48 \\
59\end{array}$ & $\begin{array}{l}4.9 \\
5.3 \\
5.7 \\
8.5 \\
5.8 \\
6.5 \\
4.0 \\
3.8 \\
3.7 \\
3.3 \\
3.5 \\
4.3\end{array}$ & $\begin{array}{r}3.1 \\
2.8 \\
4.2 \\
7.6 \\
11.2 \\
14.6 \\
14.3 \\
21.8 \\
8.6 \\
5.1 \\
3.3 \\
2.0\end{array}$ & \begin{tabular}{|}
1.9 \\
2.8 \\
4.2 \\
7.7 \\
10.7 \\
12.8 \\
13.1 \\
11.6 \\
8.7 \\
5.7 \\
3.8 \\
2.0 \\
\end{tabular} & $\begin{array}{l}44 \\
50 \\
59 \\
69 \\
77 \\
84 \\
88 \\
84 \\
74 \\
62 \\
53 \\
48 \\
\end{array}$ & $\begin{array}{l}61 \\
58 \\
49 \\
43 \\
37 \\
33 \\
30 \\
26 \\
26 \\
34 \\
44 \\
54\end{array}$ & $\begin{array}{l}400 \\
402 \\
4.5 \\
5.0 \\
4.0 \\
4.5 \\
5.5 \\
3.5 \\
2.5 \\
2.0 \\
2.0 \\
2.5\end{array}$ & $\begin{array}{r}1.6 \\
2.1 \\
3.7 \\
6.0 \\
8.2 \\
21.6 \\
1404 \\
12.9 \\
7.8 \\
4.4 \\
2.7 \\
1.9\end{array}$ & $\begin{array}{r}1.7 \\
2.6 \\
3.9 \\
6.5 \\
9.0 \\
10.1 \\
10.3 \\
10.2 \\
7.4 \\
5.0 \\
3.0 \\
1.9 \\
\end{array}$ \\
\hline $\begin{array}{l}\text { Totala } 0 \\
\text { Average }\end{array}$ & 69.2 & 37 & 8.9 & 134 & 1215 & 69 & 44 & 4.95 & 86.7 & 84.07 & 66 & 49 & 3.7 & 77.3 & 72.6 \\
\hline
\end{tabular}

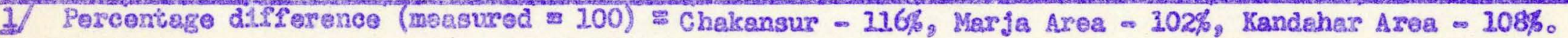

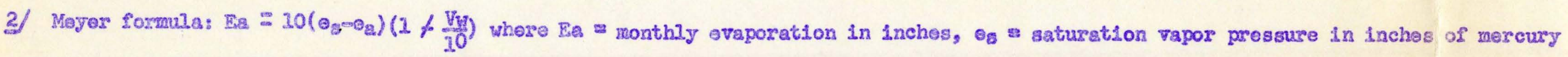
equivalont to mean $2 i x$ temperature in dogreos centigrade, $e_{2}=$ average monthly vepor pressure equivalent to relative humidity, V: $\approx$ wind veloctty in miles per hour. 
Table \& COMPARTSON OF IRRIGATION REOUIREMENTS BI DTFYERENT NETHODS

\begin{tabular}{|c|c|c|c|c|c|}
\hline Arges & $\begin{array}{l}\text { Moan } \\
\text { Bramal } \\
\text { Evaporajton }\end{array}$ & $\begin{array}{l}\text { Per Acre } \\
\text { Mean } \\
\text { Consumptive } \\
\text { Use Uy sBt }\end{array}$ & $\begin{array}{l}\text { Consumptive } \\
\text { Jse Minus } \\
\text { Rainfo1 }\end{array}$ & $\begin{array}{l}\text { Fara } \\
\text { Delivery } \\
\text { Req. at } \\
55 \% \text { I. }\end{array}$ & $\begin{array}{l}\text { Diversion } \\
\text { Reg. } \\
\text { 75\% Dalivery } \\
\text { \& 59. Ret Flou }\end{array}$ \\
\hline Arghandab & 63.84 & $1.98 \mathrm{z} /$ & 1.45 & 2.63 & 3.29 \\
\hline$(206.5) \mathrm{Ld}$ & 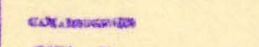 & 2.403 & 1.85 & 3.36 & 4.20 \\
\hline Kandahar & 77.3 & 2.403 & 1.96 & 3.56 & 4.45 \\
\hline $\begin{array}{c}(2.00) \\
\text { (and }\end{array}$ & 72.52 & $2.25 \mathrm{~J}$ & $2.82(2.9)$ & 3.45 & 4.30 \\
\hline arja (Gan .Area) & a) 8406 & $2.03 \mathrm{~J}$ & 2.34 & 4.25 & 5.31. \\
\hline$(1.063)$ & - & $2.39 \&$ & 2.20 & 3.81 & 20076 \\
\hline Darweshan & 108.1 & $3.343 /$ & 3.08 & 5.60 & 7.00 \\
\hline$(1.078), 4$ & - sereasa & & 2.17 & 3.94 & 4.93 \\
\hline Choikansurs & 213 & $3.56 \mathrm{z} /$ & 3.40 & 6.18 & 7.72 \\
\hline$(1.092)$ & 234 & $\begin{array}{l}3.893 / 1 \\
2.46 \frac{1}{4}\end{array}$ & 4.0 .5 & 7.55 & $\begin{array}{l}9.44 \\
5.23\end{array}$ \\
\hline
\end{tabular}

17 Kardahw data hos been thoroughly studied in previous zeports and is usad here as beala for comparison.

2/ Assuming svapowtransplration can be compared on basis of d1fferences in free water evaporation as messured in open pans.

3 Asauring sane relationship as above but computing evaporation by the Meyer formula which involves the vind veloelty as one factor determining evaporation.

4/ Based on ratlo of computed consumptiva use sectors using Elaneyucriddle formula.

* Interpolated from other station records. 


\section{CLINATE OF S.W. AFGMANISTAN}

Average Rainfall-Temperature-Evooaration-Thanspiratian Relationships Data fram 10 Weather Stations

\section{8}

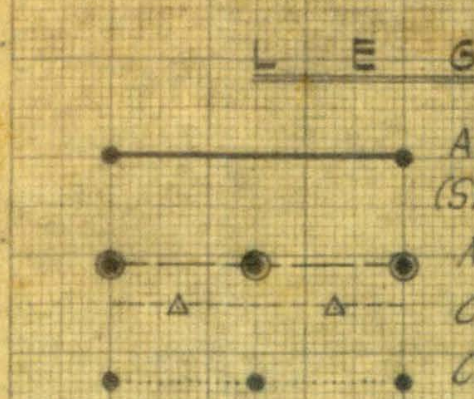

\section{S E N D}

Averoge Manthly Roinfall.

(Shaded area shoms effective raintoil)

$x 6^{\prime \prime}$

culculotedity lemperafurs.

- Computed Monthiy Consumptive Use less Effective Rainfall

for Averge Cropping Conditions Including Double Crapping. (Tatol Acreage Basis)

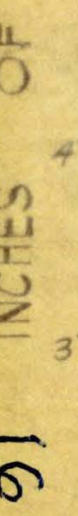

$\sigma$ 2

\begin{tabular}{|c|c|}
\hline \multicolumn{2}{|c|}{ CLIMATE\& WATER USE } \\
\hline Dramnby: ajo & Date: $7-16-57$ \\
\hline Dwg no. $\angle 0.130$ & \\
\hline File no. & \\
\hline
\end{tabular}

4

$x^{x}$
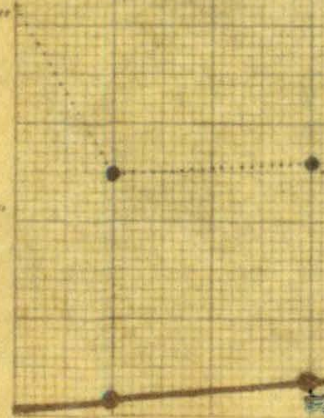
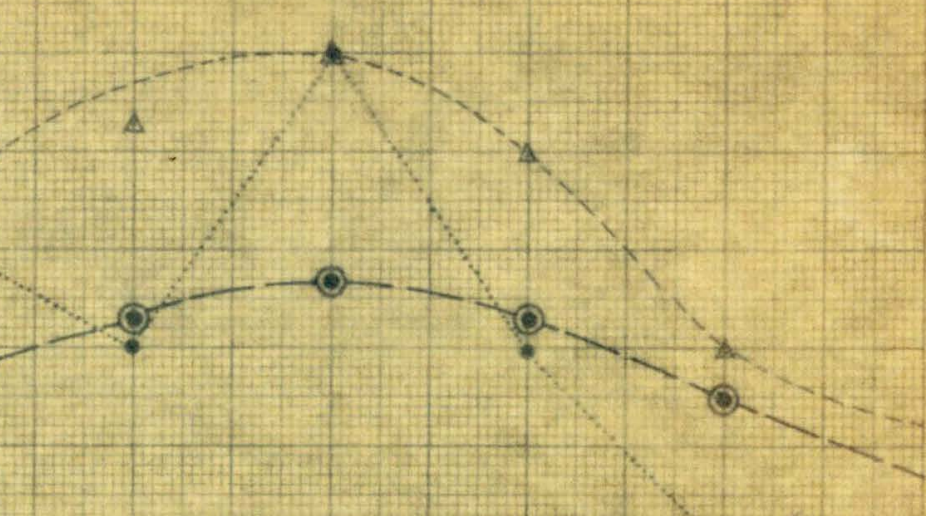

60

90 11

㟧

$60 \stackrel{8}{6}$

50 芷

40 
LE E E N D

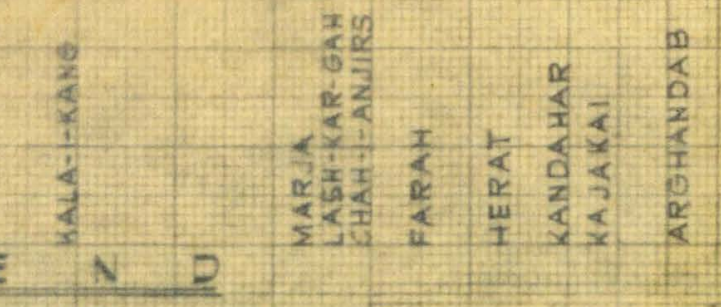
Mean Annual Temperature

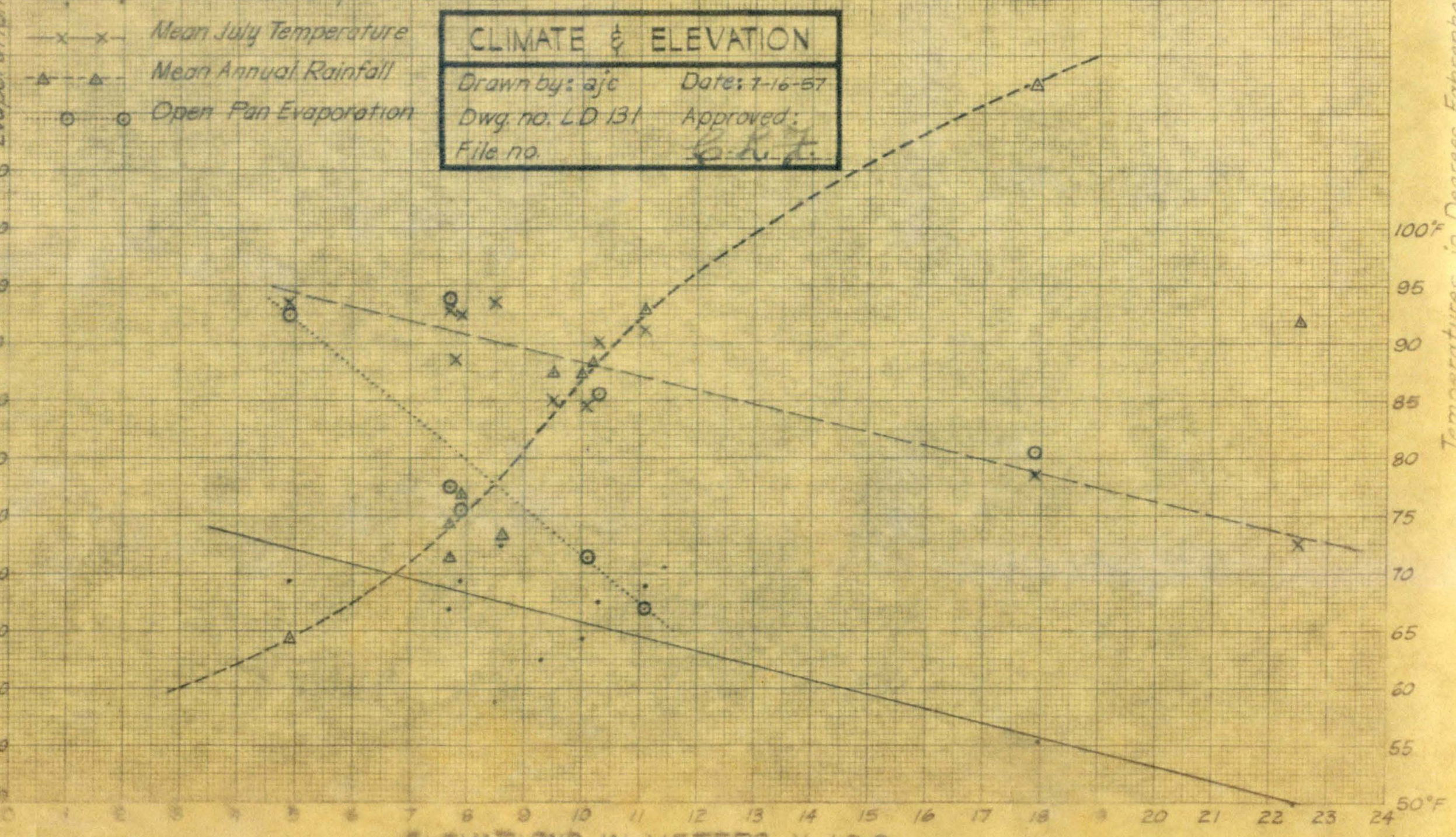


JaAUARY FEBRUARY MARCH APRIL MAY M

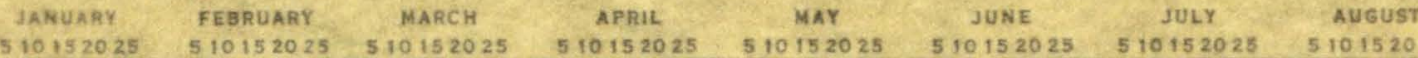

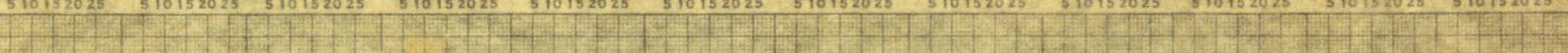
GROWING SEASONS-KANDAHAR-I9 YEARS RECORDS

$+2$

$$
\frac{L E G E N D}{E-\text { Eariestalog, }}
$$

A Average dote of frost

A Average date of frost
L Latear date, Spring or Fall

- Proportian or totah haxts betwoon $40^{\circ} \mathrm{A}$ \& po $^{\prime} \mathrm{F}$

- I Propartian of toral hodrs abave $100^{\circ} \mathrm{F}$. -

GROWING SEASON - KANDAHAR

Dramby: ajc Date:8-ia-57

Ong. 170.10139 Approned:

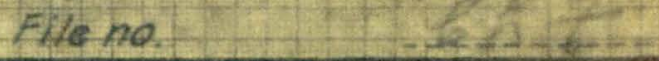

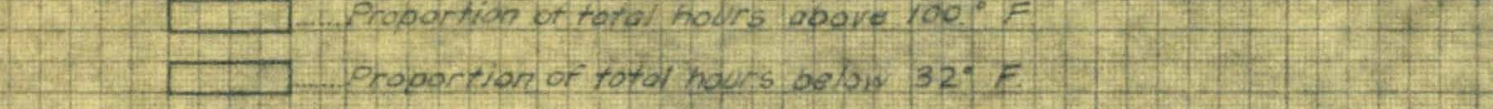

......... upper line is average monthy maximum tamperatwre.

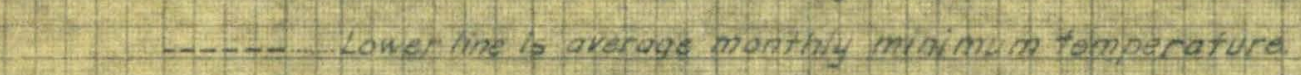

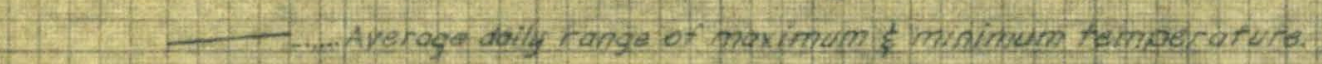

है
है
है
4
है
हू
है
5
5
है
ह
है
है

Kondohor FEOST FREE DAYG

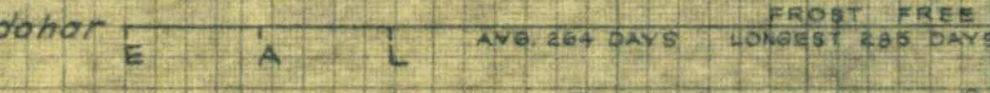

oal 2 Hosolute Moximum

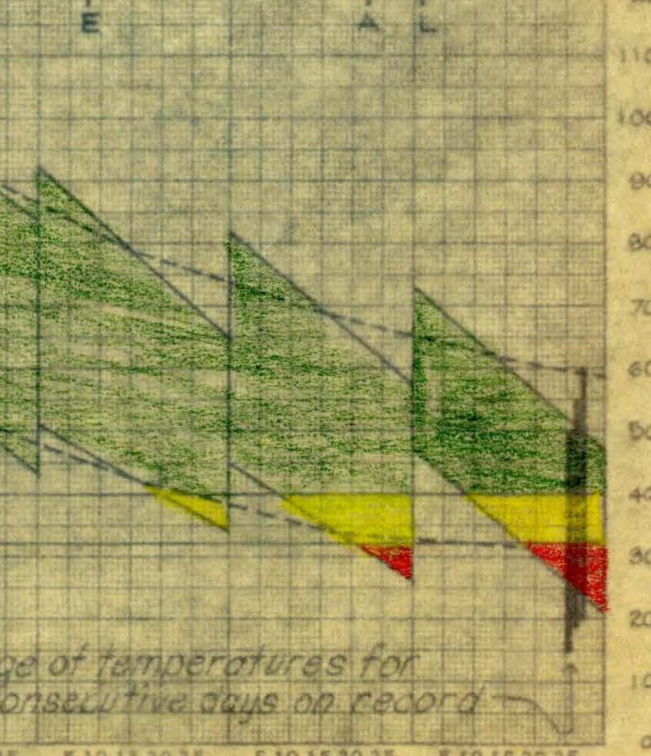

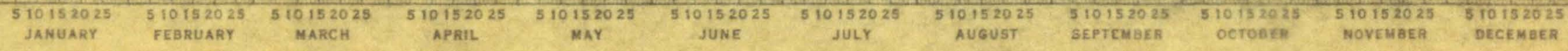


Sobruazy avarged 9 deys and Novenber 8 days. Only 7 days out of a year did the tomperatures reach $20^{\circ}$ and thon only for a very short tine. The Coniteal Helmand Area is warmer by $3^{\circ}$ or more in Deeember and January and the anmal number of days at $32^{\circ}$ or below are sbout onembals the numbar at Kandahar. The Chakansurafarah Area avexages akgut go go higher 105 December January and would be expected to have st11] few/days of Irost. There Is no record of a hoevy freeze lilling frutt trees In this area. Large sour orange troes and a few date palm have been observed In the 61ty of Randahar although none have been observed in orchards. Date

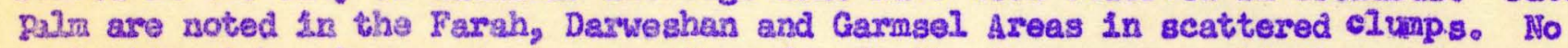
roal attempt bas beon msde to grow then for frult, they appear chierly used as orm nanoztals. F. O. Youngs planted a rumber of geedising oranges and lemons in the Nad-1wall Ares In 1949. These were growlng In 1953 when they were dug up by the Af ghans and noved to a very sallne and water-logged spot where they subsequently died. Native 015ve trees grow In abundance in the eastern part of the watarahed. P1atachlo grows throughout the lower foothill area to the west. It appeerso Irom eareivi comparioon of the temperatures and growing conditions of the middle and Iower Heimend Areas with nore developed areas elsewhere in the world,that a Iarge variety of crops lncluding clirus, dates and olives could bo grown if attention was pajd to using hardy warteties and root stocls. Tegetablos are grown year round aad cool season Legwass and grasses afrord yoar round pastuso.

\section{Generat Summas of C34mate *}

Thre graphs serve to present a plcture of the genagel relationships of various climatic factors affecting irrtgation developnent and land ume in southow west Afghandstan. Drawing LD-131 shows the comparison of tenperature, reinfall, and evaporation for the 10 stations gtudisd, axranged in order of elevation. Wh1le there is considerable Local pariation, the generel trend seon to hold that higher term peratures, lower ralniall and higher evaporation is encountered as one proceads from the uppor mountain valleys down onto the desert plain and to the lower basins. This relationship is wal borne out 2130 by the types and appeerance of naturel. vegetation.

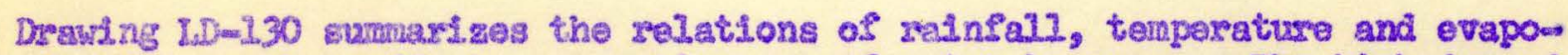
transpization as they affect consmptive use of water by cxops. The high denand

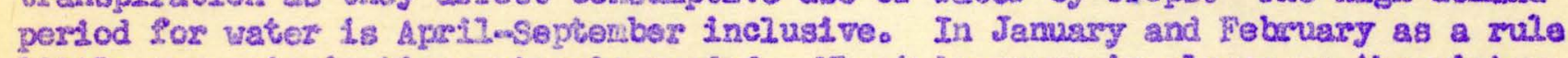

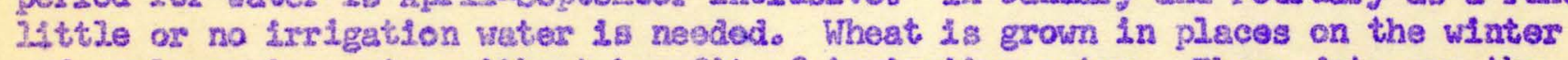
and early gomirg salns whbout benefit of 1 rugation water. These data are the averege of 20 stations. Who lower deserts and the Chakansux basin recelvo very seanty galnfal? while dyg land exops are regularily grown at the bigher alevations.

Drewing LD- 39 12Lustrates the growing season and daily temperature relat1onshipa st Kandabas. The cisily zange of minimu and maxtmu tomparatures may bo takon as an Inditeator of the proportion of hours falling into agch brecketed tomperature

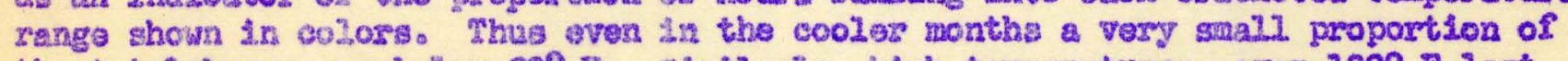
the totalithours are bolow $32^{\circ} \mathrm{F}$. Sinilariy, high temparatures, over $100^{\circ} \mathrm{F}$ last

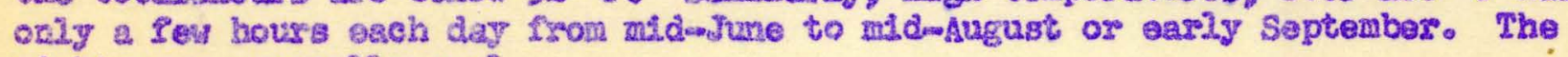
nights are generaily cool. 


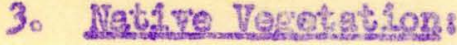

Very Iftile dats is available on the Nors of Southwest Af ghan gtas. Some published litereture in German covers parts of the area but is unavaliable for this report. From such preliminary reports as are at haxd ard general notes mode of vegetation over the area the Sollowing describes the zelation of pIant distribution, soils and clingtie situntions in the watorabed.

Roughly the watershed nay be divided Into four bzoad divishons: (1) the lower desert plains, basine and valleys, (2) the centra: to upper gravelly outsask desert,

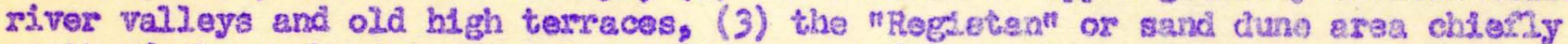
south of the Arghandeb and Helnand Rivers, and (4) the lower foothilig and nourdew

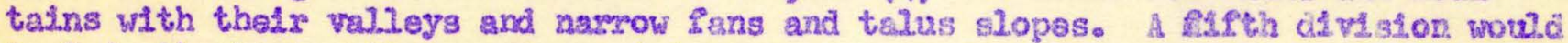
include the high valleys and mountains where some sorast typos exist.

Within each of these certain vegetative types and aseociations are noticod. The lower ceserts from about 700 meters dom into the lowegt basing at 400 meters present a generally barsen appearance except for soL1 situations more farorable to

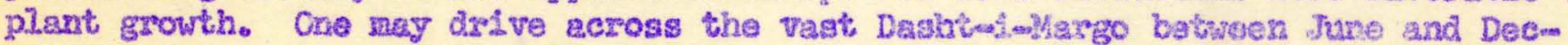
enber and see only \& Iew smell scattered communitias of Low shrubs In sand covered depresstons. In the early spring after a sertes of rain short graises, mouering shrubs, and low plants, Including mumerous low or orseping legurnes, seer to 21 tezm a.7y spring out of the ground and more favored apots resemble mind ature sloves" gardens. Whth the IIIrst high tenperatures of sumer, however, the green landscape is quickly reduced to Its typlcal desolate appearanse with the sunmblacicened, glistening gravels constituting the princlpal cover. Oaly the rifvar valloys and the maxhes of the basins bear much vegetation. Depth to Eround water, so11 t\$xture and degree of $3 a l i n d t y$ largely conrol the speedes on each st.te. The sendy Llood plains and stabilized river wash areas ane covexed chierly with temartest. and occastonal clumpg of tall grasses. Noxt to the rtrear beds axe wi21ows, ash, sedges and glant reed grass. The deep alluvial and Jake basin solis which are Proe of salts or only slightly saline are covered by mal.I thorty shrubs such as a wimw

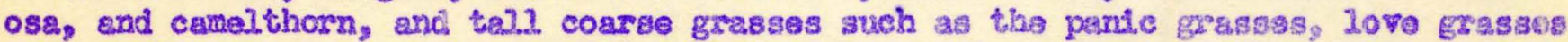

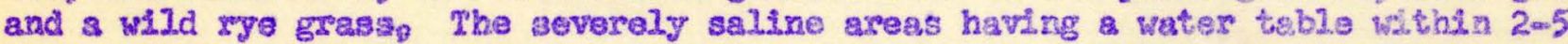
meter are usualiy covered with a coerse grass having a tough hesvily gheakined tap root. This is a phreatophyse, feeding on the caplilary IxJnge above tho wator tablo gt

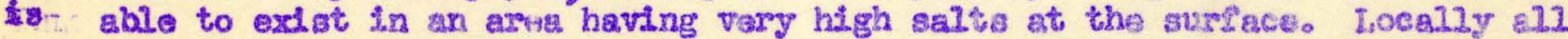
these gxassea are raferred to as winter to early sumner but bocone too coarse In fuli growth to be pelstabie. Ex-

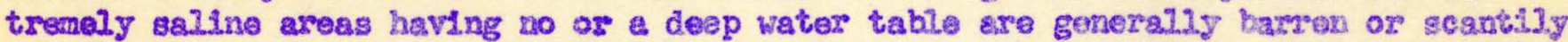
covered with malt weeds, gexsrally the Chenopodiaces, such as clumps of salsola ena, halogeton-ijke planta. The hard-packed silty clay solis of tha Chakaras Baidn are smooth and completely bamen over ireat stretches. The high actively shiftcm Ing sand dunes also are generally barsen. Ovar 200,000 acres of such dures bate collacted in the southeast part of the Chakangur Basin. Fundreds of squere mi.3es of moving dunes occus on the desolate stretches of the "Reglgtan", a vost territhory Iying between the desert plaing and the 10 nountain ranges of Brluchisters. Nurnarous unidentlfled gxasses and shrubs are growing on the Lowex less active gands.

The central and upper dosert fans and river valleys have similar species but, with more favorable rainfolt and slightly cooler seagons, have meintainad a wan

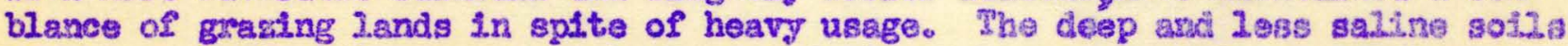
are charecterized by munerous shrubs and forbs guch as artemisia, canelthom, and dwarf mimosas. The tallex more palatable gresses have been pretty well degtroyed by hundreds of years of grazing by sheep and goats but stips, aristida and brone grasses are found. Bulbous blue grass is seen in abundance in the early spring. Dozens of unclassified votches, clovers and other legumes appear in the oaxly spring 
and furnish renexirably good grazing for a short period. Poplar, ash and willow grow along the streans. A fow slowerting and fruiting shrubs such as wild almond, pistachio, w11d prune, cotoneaster, and silver bexry appear along the dry weshes, upper outw wash fans and low rocky foothills. The tree tamariak (ghaz) and cypress (cupressus torviosa or c. semperviseas) grow in isolated oeses or where protected as in comem teries or courtyards. Wild irls, tulip, poppy, pexstemon, and numerous other flowexing plasts make beautifu? meadows and the mixture of legumes and grasses make excellent pasture Irom Febmary through May depending on the amount and alstribution of the winter ard apring reins. The saline-alkali lands and wet lands support similas vegetation to that already described for these gites but in greater amounts.

From sbout 1,100 meters to 2,500 noters are chlerly small valleys foot slopes and rugged foothilis and nountains. The mubor of shrubby species ard smell trees insreass in favorable sites but the general appeerence except in exrly spring is stil1 barren to scantily vegotated. Spscies of almond, plstachio, wild pruas, haw thorn, rook rose, wild ollvo, barbarry, prIvet and zizyphus appear. Grasses such as

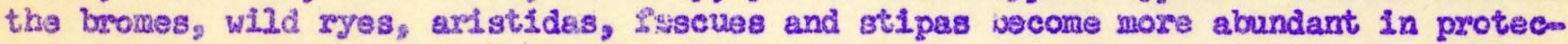
ted places. Sycamore, poplar, ash, willow, viburnum and other trees grow in wellvatered sites.

The higher and more asterly forested sites are chjeny in the Nuristanfeastem provinces and outstide the watershed of the Helnand. Here in addition to species mentLoned are pine,deodar ceder, lerch, oak and several associated species. Tho growh of trees under irrigation or along the water courses for wood and lumber is of real Interest to the Afghan Goverament and an inftial afforestation project is included in the Helmand Velley developwent program.

Table 9, summaxizes what 1ittie informetion is avallable on the plore of the watershed. The major subitivisions of the watershed are based chiofiy on elevation axd climete. The subjivisions ere vegetative sites based upon soln charecteristies and degrees of sallntty and alkalinity affecting plant adaptstion and growth. The nosmal site for a species is indicated by a check maxk and aites of Iirited adaptam tion by the Letter nI". ThLs Is a temtative site grouping only. Much study Is needed to furnish e good vegetative ste map anô classification of Afghangtan Ilora. 
In orcles to determine the relativo contributlon to the agratcul turel aconomy of the country that may be expected from the Iand development progran row going on in the HelmandeArghandeb Valleys and Plaing It 18 necessery to balro a lock at the present attustion.

In a country which hss no Eact-gathoring agencies and consequatily no ye1iable statistics on population, agricultural land axeas, crop production, max keting or other phasea of economy one must apporoch this subject with a great deal of caution to avold unres.listle assumptions and conelustonso The following study is based on rationalizing the vasious interrelated factors so thet such data as appears factual is given due welght and no deviously unreasonate deta or ssaumptions are 1atroduced into the final analyses.

A. Population, I1ving Standerds and Food Congumption:

\section{Population:}

The avallable statisties on population seen to be in disagxacment wh other factor of cultivated acrea, production lovels, 3abor incorne, and dietery

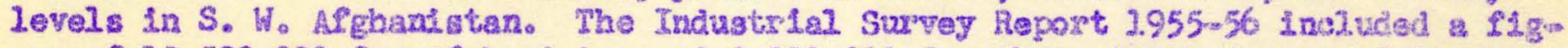
ure of $12,500,000$ for ASghanistan and $3,000,000$ for the waterghed aroa of the his l. mand ginks (Chakansurmsjestar Basins). The Tudor Report (1956) estimated

$2,200,000$ in the Kandaher and Girs shk Provinces with about 602,000 21.ving within that part of the waterahed presentily affectod by the Helmand Valloy developrent progran. Fox the moment one can only assume these flgures and proceed to study othar related phases of the reglonel econony.

\section{Wage Earniags:}

Phrse I of the helmand Valley Industrial Survey reportad about 3,000,000 parsons in $\mathrm{S}$. W. Afghantstan with nn average wage income of only 3500 Afghan:s pe: year or 290 Afghanis per month for the 500,000 assumed to be enployed. In some

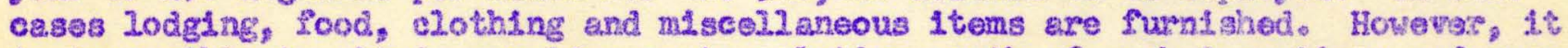
L. Imposible to obtsin axy 1dea as to relative worth of auch 2 seentives and somo Afghans with a more thorough knowledge of conditions state that thege axe vary minor and are not a substantial contribution to living. Housing is so easily con. structed that the 1tem of rent ordinaxily does not enter Into the low 1 reome 13 . ing costa snc so from this gtandpolnt ay be considered as an incentivo.

MRA Afghan enployees in coxtaln wage brackets are givon the privilege of purw chassing whoet for bresd from the company duxing pariode whon besar. pricos are ax cessite. Dre to lack of meriset controls and storage facillties the whest prlces have fluctuated fron around 4 er Afghenis per maund at the pask of harvest to as much as $30-35$ Afghenis per maund during the winter months. Having no capital to buy in largo quantities and no safe place to store wheat, the ordinary workar 1.5

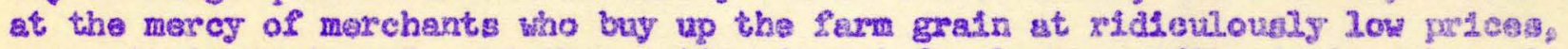
store It In "godown", and then retion it out sor large proflts during the wid

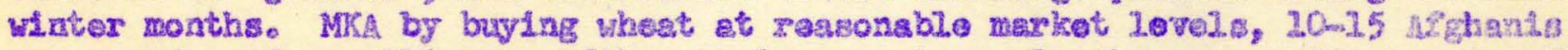
per maund, and resel.ling to Afghan mployes at nearly the sane price has In affet addad at least mother months wges to many exployees earnings.

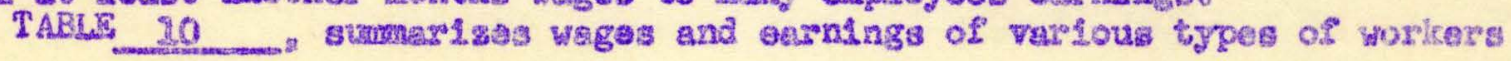


2n So W. Afghan atano These vage tovels are those reported by enplojees and ano ployers during a study made by MRA for Phase I of the Melmand Valloy Industrial Survey, 1955. The wage standards for MKA ASghan caployees as $21 \times 1 \times d$ ky govern ment rogulations are glven for comparison.

Common laborer and apprentlee earnings are about the sane as the raported

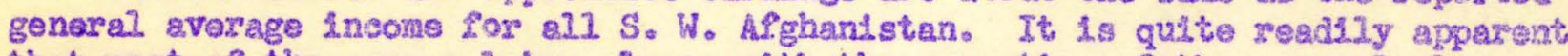
that xost of the cormon labor class, with the exaeption of those regularly onm ployed by the government or MKA, must earn much less than 500 Afghants assured to be the arerage. Skinled labor earnings are cormonly twice to throe tires the average level of a comnon laborer's wages.

\section{Living Cogts}

At the bottom of TABLE -20 is shown for comperison three lovels of

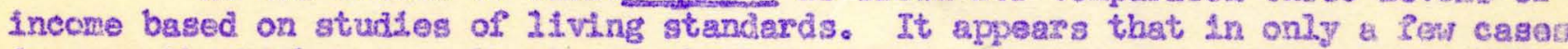

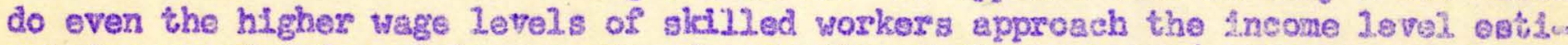
mated as needed for minimura neech of a family of six porsons (eatingtexl average fenly group per wage earner). TARth 11 shows how a femily of six mear dis tribute their earnings at different levels of Incorto. Food, clothing, fuol, shein ter, modiestion, and 11ght would undoubted 3 s asorb the grastest proportion of

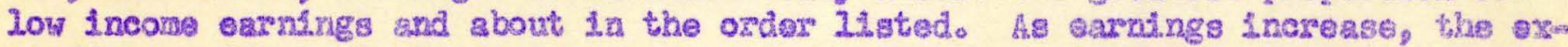
penditures for these basio ttems are Inereased to more dosirablo levele and othor

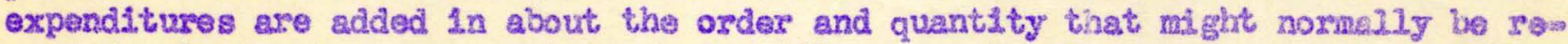
quired. Income tars are not imposed tant11 gross anmuel earnings reach 13,000 Afghanis, however rentals or business taxes are assessed on bazsas quarter"s, and business exrnings starting at about $200 \mathrm{Afghanis}$ and increas1ng with size and 10 cation of the establisbment and volume of buslness.

As can be seen by study of TABLE 21 , nost of the people of S. W. Arehsidw istan 2ive on a wage level balow 3500 Arghanis a year per fomily. About $8.5 \%$ carn onough to eet a sustalning diet, buy enough clothes and expend some money for housing, medication, and schoo2. Another 3.10\% earn whet may bo tormed a reasonable standerc. which affords an adequate and balancod ditet, isuffitefent olothes and utilities, contributes toward school, eduestlon and taxsa and allowe a smoll saving for investrenta amounting to $3.5 \%$ of the incone. Fven at thas level, 50\% of the Incone Is required for food ss conpered to $29 \%$ for the \&verege U. S. Lantly. Less than $1 \%$ have 2 wage sarning comparable on a food Inder basts to $70 \%$ of the averege 0 . S. Incons. Thus only about $1 / 8$ of the population can contribute anch towerd schools, hospitals, goverrment revenue or even onjoy a verg good diet highly diversifled with meats, milk, fruits and vegetables (excert on occsions)。

\section{Riats and Food Consumotion:}

A study of the presemt and potentlal diets reveels the affect of a strictly grain diot on land use and potential land devalopaent in S. W. Afghantgo tan. In TABLS 12, is shown the per caplts and fandly consuration of varjous food 1toms for four types of diets. Afghan bezas patces (TABLES 13 and 14 ) and stateside grocery retall prlees are used to compute compsrath ye costs. D19t \#1. Is one which wilu surnith more than adequate celorie and proteln intake, is fatrly well alanced with respoct to nutrient requirements, vitamins and minerals? and Ineludes only erops groun within S.W.ASghan'stan. The FAO (Indted Nations) Internationa? atandard zoconnend an overall calorle fintake of $2550-2650$ calortes and proteln Intake of about 65 graros dally. The U. S. ATexage, 1945-1955, vas

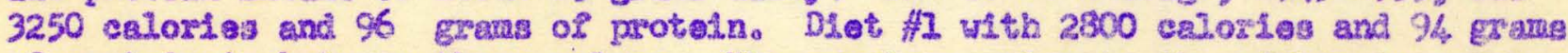
of proteln is betwemn these valises. The purehase peseo to the Afghan is caleu-

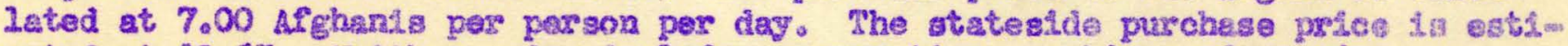
mated at $\$ 0.87$. Hetther profee Includes preparation, eooldng and sarvingo 
"PABLE 20 COMPARISON OF WAGE SCATES IN S. W. AFGIANISPAN -1955

\begin{tabular}{|c|c|c|c|c|}
\hline TYPE OF WORKER & $\begin{array}{l}\text { MONTHEI } \\
\text { MINIMUUM } \\
\text { AIS }\end{array}$ & $\begin{array}{c}\frac{\text { ARNIRGS }}{\text { MAXIMTMM }} \\
\text { AFS }\end{array}$ & $\begin{array}{l}\text { ORHER } \\
\text { INCENR IVSS } \\
\text { AES }\end{array}$ & $\begin{array}{l}\text { POSSIBUE ARNUAI } \\
\text { INCONE } \\
\text { AFS }\end{array}$ \\
\hline \multicolumn{5}{|l|}{ Reported Afghan Scoles } \\
\hline Cormon labor & 200 & 250 & Not possible & $2600-3.300$ \\
\hline Mechanle & 354 & 624 & $\begin{array}{l}\text { Sone food, } \\
\text { lodging, elothe }\end{array}$ & $4700-8200$ \\
\hline Cexpenter & 281 & 515 & $\begin{array}{l}\text { Ing and ing } \\
\text { colleneaus } 1 \text { ters }\end{array}$ & $3700=6800$ \\
\hline Blacksm! th & 354 & 624 & $\begin{array}{l}\text { are furmi ahed. } \\
\text { Tota? is est,j- }\end{array}$ & $4700-6800$ \\
\hline Clerk & 300 & 800 & $\begin{array}{l}\text { mated at } 20 \% \text { of } \\
\text { annual ware }\end{array}$ & $4000-10,500$ \\
\hline Basket maker & 281 & 500 & & $3700-6600$ \\
\hline Metal. worker & 370 & 700 & & $4900-9200$ \\
\hline Pottery worke: & 320 & 600 & & $4200-8000$ \\
\hline Riug weaver & 4,00 & 800 & & $5200-10,300$ \\
\hline Wood worker & 320 & 600 & & $4200-8000$ \\
\hline $\begin{array}{l}\text { (Eat. Average Cash Incone } \\
\text { MKA Wage Scales }\end{array}$ & $(290)$ & $-\infty$ & (No Incent1ves) & (3500) \\
\hline Apprent1ce & 260 & 385 & $30-50$ & $3500-5200$ \\
\hline 3rd Glass & 400 & 500 & $40-60$ & $5300-6700$ \\
\hline 2nd C2ass & 450 & 550 & $60-70$ & $6000-7 / 00$ \\
\hline 1st Class & 500 & 650 & $65-80$ & $6800-5700$ \\
\hline Sub Foreman & 550 & 750 & $40-60$ & $7000-9700$ \\
\hline Foreman & 650 & 1250 & 65200 & $8300-16.000$ \\
\hline High Standard (AII Cogts) & 2500 & Over & (None) & 30,500 " \\
\hline Mod。 Standard (AII Conts) & 1250 & 1500 & (None) & $27,840 \Rightarrow$ \\
\hline Low Standasd (A2) Costs) & 800 & 1000 & (Hone) & $20,800 \mathrm{H}$ \\
\hline
\end{tabular}

* Wage Incorse levels for comparative study。 
$T A B T S \quad 22$

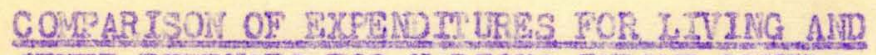
OMATR ERPENGES FOR YARTOUS THCOMS TEVTLS -

S. U. AECHANISTAN, 3255 CONDTPLONS

(FAMZII OF 6)

\begin{tabular}{|c|c|c|c|c|}
\hline cost mex & $\begin{array}{l}\text { EST, AVRRAGE } \\
\text { ANNUR INEONE } \\
\text { S. U. ATCHANISTAN }\end{array}$ & $\begin{array}{l}\text { MINTMOM } \\
\text { STANDARD 2/ }\end{array}$ & $\begin{array}{l}\text { DESIRABI: } \\
\text { STANDRRD } 3 /\end{array}$ & 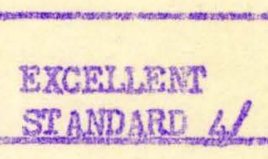 \\
\hline Glothes & 200 & 500 & 1700 & 2500 \\
\hline pood & 3250 & 8000 & 20,020 & 13,000 \\
\hline Pruel & 125 & 300 & 600 & 2000 \\
\hline Reat & $-\infty$ & 400 & 1000 & 2500 \\
\hline Medication & $a$ & 200 & 400 & 1000 \\
\hline $\begin{array}{l}\text { Draft Power or } \\
\text { Srensportation }\end{array}$ & - & 200 & 300 & 1000 \\
\hline $\begin{array}{l}\text { Pexsonal \& } \\
\text { Miscellaneous }\end{array}$ & - & 100 & 600 & 1000 \\
\hline $\begin{array}{l}\text { Teszes (Bustiness \& } \\
\text { Personal) }\end{array}$ & $\rightarrow$ & 300 (Bus. & 700 & 2000 \\
\hline Rellglous Organ. & - & 100 & 200 & 2000 \\
\hline Sehool & 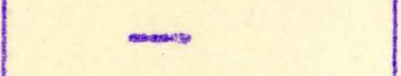 & 100 & 2.000 & 3000 \\
\hline Household & - & 200 & 300 & 500 \\
\hline L\&undzy & - & 100 & 200 & 500 \\
\hline Lights & - & 100 & 400 & 2000 \\
\hline Sarings. & 25 & 100 & -400 & 2000 \\
\hline & 3500. & 10,800 & 27.840 & 30.500 \\
\hline \multicolumn{2}{|c|}{ U.S. Eqvo @ 22.267.1 $\$ 26 / .57$} & $\$ 507.82$ & 838.85 & 12434024 \\
\hline \multicolumn{2}{|c|}{ W.S. Eato (3) L2.534.3. 82.28} & $\$ 253.90$ & $\$ 419.42$ & $\$ 17.05$ \\
\hline $\begin{array}{l}\text { Sst. \% Workers at } \\
\text { each Jerel }\end{array}$ & $\begin{array}{c}\text { (at or bolow } \\
3500) \\
37.55 \\
\end{array}$ & 804 & 3.12 & 0.93 \\
\hline Est. No, workers Id & 437.750 & $-42,050$ & -25.550 & 26050 \\
\hline
\end{tabular}

1 Estivated averago wage earning - Heinand Valloy Indugtrial Surviy keport, 0 tober 1955, Munber of wage esrnars S. W. Afghand stan ast1mated at 500,000。 Note: Later in this report it is polnted out thet the population 19ure is probably $3 / 2$ that quoted here.

2/ Studies conduetsd by DIS and MRA and varimed by nunerous Afghang Indiesto this as about the resnimun lovel.

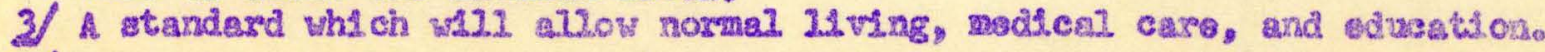
W Equivalent to less than 2955 averege U. S. per csptis Ineans. 


\begin{tabular}{|c|c|c|c|c|c|c|c|c|c|c|c|c|c|c|c|}
\hline CPOPS & $\begin{array}{l}\text { DEG } \\
1955\end{array}$ & $\begin{array}{l}\text { JAlN: } \\
2956\end{array}$ & $\begin{array}{l}\text { FEB } \\
1956\end{array}$ & $\begin{array}{l}\text { MAR。 } \\
1956\end{array}$ & $\begin{array}{l}\text { APR。 } \\
1956\end{array}$ & $\begin{array}{l}\text { MAY } \\
1956\end{array}$ & $\begin{array}{l}\text { JUN。 } \\
2956\end{array}$ & $\begin{array}{l}\text { JuL = } \\
2956\end{array}$ & $\begin{array}{l}\text { AUG. } \\
1956\end{array}$ & $\begin{array}{l}\text { SEP. } \\
1956\end{array}$ & $\begin{array}{l}\text { OCI } \\
1956\end{array}$ & $\begin{array}{l}\text { NOV. } \\
1956\end{array}$ & $\begin{array}{l}\text { DEC } \\
3959\end{array}$ & & \\
\hline Haerat & 14.00 & 17.00 & 13.00 & 15.00 & 16.00 & 14.00 & $1 \% .00$ & 15.00 & 16.00 & 18.00 & 16.00 & 15.00 & $\mathrm{rs} \cdot \mathrm{c}$ & & \\
\hline Suras: & 4.00 & 4.00 & 4.00 & 5.00 & 5.00 & 6.00 & 3.00 & 3.00 & 8.00 & 3.00 & 2.50 & 2.00 & 3.0 & & \\
\hline Alyer Go Gon & 2.00 & & & & 5.00 & 3.00 & 2.00 & 3.00 & 3.00 & 2.00 & 1.50 & 2.00 & 2.09 & $a^{\prime \prime}$ & \\
\hline Alsalí Seod & vensosiman & & & & & & & & & 20.00 & 20.00 & 20.00 & 20.0 & 2 & \\
\hline $\operatorname{Cos} x(g \sin )$ & 8.00 & 8.00 & 8.00 & 8.00 & 8.00 & 8.00 & 8.00 & 8.00 & 7.00 & 12.00 & 11.00 & 12.00 & 12.0 & $?$ & 1 \\
\hline Sorghum (grain) & 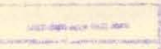 & & & & & & & & & & & & & & \\
\hline Sugar Boets & $\cos 20-1-$ & & & & & & & & & & & & & & \\
\hline Gotton (Int) & 96.00 & 76.001 & 100.00 & 100.00 & $100.00 \mid$ & 100.00 & 100.00 & 100.00 & 90.00 & 90.00 & 90.00 & 90.00 & 85.4 & 60 & \\
\hline Molons & 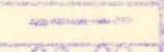 & & & & & & 12.00 & 7.00 & 6.00 & 5.00 & 6.00 & 16.00 & $=$ & & \\
\hline Bice $\quad-\quad-$ & 23,00 & 24.00 & 29.00 & 26.00 & 24.00 & 24.00 & 24.00 & 28.00 & 25.00 & 30.00 & 25.00 & 24.00 & 23.4 & 40 & \\
\hline Grapes Frosh & 10,00 & & & & & & 15.00 & $\theta-10$ & 10.00 & 12.00 & 14.00 & 20.00 & 30.0 & 21 & \\
\hline Crepes DXY & $40-95$ & $50=110$ & $50-110$ & $50-110$ & $50-110$ & $50-110]$ & $|50-110|$ & $50-110 !$ & $150-120$ & $60-80$ & $60-90 \mid$ & $60-75$ & 60.9 & 25 & \\
\hline Meat (Boe? & 44.00 & 44.00 & 44.001 & 04.00 & 30.00 & 30.00 & 30.00 & 30.00 & 30.00 & 45.00 & 45.00 & 45.00 & 40. & 60 & \\
\hline Hides _ & $S$ & & $i 0-25 i$ & aci.j. & Cum 50 & $1-i v 0$ el & o., Evere & keíco & CES sora & Csw- & $\therefore 2 ; 512 x$ & $2630-403$ & Con: & -30 & 200 \\
\hline Wool 140 & 40.00 & 70.00 & 20.00 & 70.00 & 60.00 & 50.00 & 60.00 & 60.00 & 60.00 & 55.00 & 60.00 & 7000 ? & 70. & 21 & \\
\hline Meverseed Su Clov & $-\infty \cdots$ & & & & & 4.00 & 5.00 & 6.00 & & & & & & & \\
\hline Guaver Hay _ _ & $\cos (x)$ & & & & & & & & & & & & & & \\
\hline Clovor Pasture & 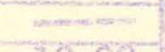 & & & & & & & & & & & & & L & \\
\hline Blackejed Foas & 18.00 & 19.00 & 19.00 & 19.00 & 19.00 & 19.00 & 19.00 & 19.00 & 17.00 & 22.00 & 20.00 & 16.00 & 16.0 & 20. & \\
\hline Botetcos _____ & 8.00 & 9.00 & 10.00 & 10.00 & 10.00 & 6.00 & 6.00 & 8.00 & 6.00 & 10.00 & 8.00 & 10.00 & 10.0 & 0 & \\
\hline Wiater Peas & 18.00 & & & & & & & & & & & & & & \\
\hline 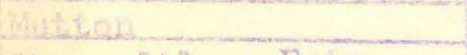 & 70.00 & 75.00 & 75.00 & 76.00 & 70.00 & 60.00 & 60.00 & 60.00 & 60.00 & 70.00 & 70.00 & 70.00 & 70.4 & po & \\
\hline Siace 017 or Fats. & 90.00 & 90,00 & 90.02 & 50.00 & 20.00 & 20.00 & 90.00 & 20.00 & 90.00 & 180.00 & 160.00 & 160.00 & 120.8 & 20 & \\
\hline$m+1 k+\ldots=-20$ & 6.00 & 10.001 & 12.00 & 12.00 & 12.00 & 12700 & 12.00 & 12.00 & $12 \cdot 00$ & $|12.00|$ & 12.00 & 16.00 & 16.9 & po & \\
\hline Wis Jong An Seagon & 3.00 & & & & & & & & 6.00 & 2.50 & 2.50 & 3.00 & 4.0 & 2 & \\
\hline Wome troes & 3.00 & & & & & 15.00 & 10.00 & 10.00 & 8.00 & 4.00 & 10.00 & 10.00 & 10.0 & 0 & \\
\hline Sucet Corn & $-2-1-\sin$ & & & & & & & & & & & & & & \\
\hline Doinas & 300 & 6.00 & 8.00 & 12.00 & 10.00 & 6.00 & 8.00 & 9.00 & 8.00 & 8.00 & 10.00 & 10.00 & 12.0 & 20 & \\
\hline nabla Bests & 4.00 & & & & & & & & & & & & & & \\
\hline Radisbes & 2.00 & & & & & & & & & 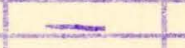 & - & $\longrightarrow$ & 5.0 & 30 & \\
\hline Cadrets & 3.00 & 3.00 & 3.00 & & & & & & & - & $=$ & 4.00 & 400 & 3. & \\
\hline Muscipips & 3.00 & 3.00 & 3.00 & & & & & & & 2.00 & 2.00 & 3.00 & 3.0 & 2 & \\
\hline Squasib & cosencos & & & & & & & & 6.00 & & -1 & & & & 5 \\
\hline Cucumbers & 14,00 & & & & 15.00 & 15.00 & 10.00 & 9.00 & 12.00 & & $\ldots$ & & $\underline{-}$ & & \\
\hline Casibages & 3.00 & & & & & & & & 16.60 & 15.00 & 20.00 & 18.00 & & & \\
\hline Wore plant & $x+2 x=$ & & & & & 10.00 & {$[10.00 \mid$} & 10.00 & 6.60 & 90.00 & 130.00 & 120.00 & 120. & $\infty$ & \\
\hline$\frac{\text { eud fower }}{\text { roen } \text { snop Heane }}$ & 80.00 & & & & & & & & & & & & & & \\
\hline
\end{tabular}




\begin{tabular}{|c|c|c|c|c|c|c|c|c|c|c|c|c|c|c|c|}
\hline CROPS & $\begin{array}{l}\text { DEC . } \\
1955\end{array}$ & $\begin{array}{l}\text { JAN } \\
3956\end{array}$ & $\begin{array}{l}\text { FEB。 } \\
3956\end{array}$ & $\begin{array}{l}\text { MAR。 } \\
1956\end{array}$ & $\begin{array}{l}\text { APR。 } \\
2956\end{array}$ & $\begin{array}{l}\text { MAY } \\
1956\end{array}$ & $\begin{array}{l}\text { JUस } \\
1956\end{array}$ & $\begin{array}{l}\text { JuL. } \\
1956\end{array}$ & $\begin{array}{l}\text { AUG. } \\
1956\end{array}$ & $\begin{array}{l}\text { SeP. } \\
2956\end{array}$ & $\begin{array}{l}\text { O5T. } \\
2056\end{array}$ & $\begin{array}{l}\text { Nov } \\
1956\end{array}$ & $\begin{array}{l}35 \\
19\end{array}$ & 6 & $\begin{array}{l}\text { JAN } \\
195 ?\end{array}$ \\
\hline Dry Raans/Pess & 9.00 & 9.00 & 9.00 & 2.00 & 9.00 & 0.001 & 9.00 & 0.02 & 9.80 & 10.00 & 11.00 & 9.00 & 9. & 00. & \\
\hline Dese' Pl.CWF & 16.00 & 13.00 & 18.00 & 16.00 & 17.00 & 15.001 & 10.201 & 12.50 & -6.60 & 23.00 & 20.00 & 16.001 & 17. & 00 & \\
\hline Sugar & 45.00 & 45.00 & 45.00 & 45.00 & 35.001 & 3.5 .001 & 45.00 & 8.02 & $\$ .5 .00$ & 100.00 & 80.00 & 45.001 & 25. & 00 & \\
\hline Ppineco & 3000 & 3.02 & 3.00 & $3 . \mathrm{c} 2$ & & & & & & $19-1$ & cone. & & 5 & & \\
\hline 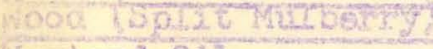 & 3000 & 2.52 & $2 \cdot 50$ & 2.50 & 8.50 & 2.50 & 2.50 & 2.50 & 8.50 & & 00 ats & in wint & ter & & \\
\hline Wustara 013 & sensings & & & & & & & & & & & & & & \\
\hline 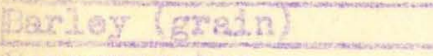 & 10.00 & 9.00 & 9.00 & 9.00 & 9.00 & 9.00 & 9.00 & 9.00 & 9.00 & $10 \cdot 00$ & 10.00 & 10.00 & 12. & $\infty$ & \\
\hline Tomerzaneces & 5,00 & 3.421 & 5.00 & & & & & & & 6.00 & 5.00 & 9.00 & 18. & 00 & \\
\hline Eaches & 10.00 & & & & & & & 10.00 & 10.60 & & & & & & \\
\hline 1.pricots & 20.00 & & & & & 12.20 & 10.00 & & & - & - & - & $\ldots$ & - & \\
\hline Tlume & 20.00 & & & & & 6.00 & E.cos & & & $-\quad$ & - & $-\infty$ & -1 & -1 & \\
\hline Apples & 20.00 & 40.001 & 60.60 & & & & & 10.00 & 10.00 & 10.00 & 18.00 & 20.00 & 32. & .00 & \\
\hline ids $($ try & 20.00 & 40.00 & 40.00 & $362=00$ & & & & & & 50.00 & 60.00 & 50.00 & 50 & 00 & \\
\hline 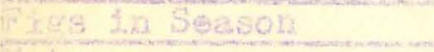 & 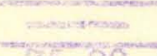 & & & & & & 20.60 & 20.091 & 20.00 & 12.00 & $-\quad 1$ & $-n-1$ & $=$ & -1 & \\
\hline 601 & 75.00 & 75.00 & 33.02 & -5.62 & $-8=0 ; 0$ & $75 .=0$ & 35.00 & $75: 001$ & $78^{5} 22$ & 70.00 & 65.00 & 85.00 & 106 & .00 & \\
\hline Cobaceo & 14000 & 29.00 & 20.00 & 25.00 & 30.00 & 60.50 & $-i 0.80$ & $3 \% .00$ & 40,20 & 30.00 & 30.20 & 30.00 & 35 & 00 & \\
\hline Dates & 60.00 & 40.00 & 50.00 & 80.00 & 40.00 & 40.00 & 40.00 & 28.001 & 50.00 & & & & & & \\
\hline Culicks & 20.00 & 20000 & 25.00 & 25.00 & 25.00 & 25.00 & 25.00 & 25.00 & $\{5.00$ & each & $25 \cdot 00$ & 18.00 & Ee & .00 & e26h \\
\hline Las CCozbage Chesse & $15-25$ & $(5-25)$ & $15^{2}-25$ & $15-25$ & $15-25$ & $15-25$ & $15-35$ & $45-25$ & $15-25$ & $\therefore \cdots$ & $6-8$ & $6-8$ & 6. & 10 & \\
\hline 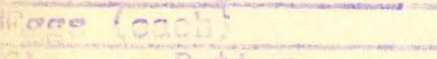 & .60 & .60 & .60 & .60 & .60 & .60 & .60 & .60 & .60 & eact & 0.60 & 0.70 & 0. & 75 & \\
\hline Choo oy Butter & 230.00 & 140,00 & 160.00 & 160.00 & 160.001 & 160.00 & 120.00 & 180.001 & 120.00 & 30.00 & 90.00 & 50.00 & 10 & 200 & \\
\hline Qopoy Seeds & 50.00 & & & & & & & & & 30.00 & 30.00 & 35.00 & है & .00 & \\
\hline A monds & 75.00 & 76.00 & 75.00 & 75.00 & 75.00 & 75.00 & 90,00 & 90.00 & 90,00 & 90.00 & 60.00 & 60.00 & 80 & 00 & \\
\hline Gowt Meat & 50.00 & 50.00 & 50.00 & 50.00 & 50.00 & $50 \cdot 60$ & 50.00 & 50.00 & 50.00 & 50.00 & 50.00 & 60.001 & 60 & 00 & \\
\hline
\end{tabular}

\section{Animal Hixo Rates:}

Donkey logd - Iaffrom 200 yds - t/2 mi. 1.25 to $1 \mathrm{mi} .50$ to 3 mi

Comel houl - Mushk-i - Nokhud to Kandahar 1 I Afg/mile 
2 Mavnd $=10 \mathrm{ft}^{4} \mathrm{~s}$

\begin{tabular}{|c|c|c|c|c|c|c|c|c|c|c|}
\hline & 1957 & & & & & & & & $20 \mathrm{MOLTH}$ & \\
\hline CROPS & JW. & TEB & MAR & ARR. & MAT & गुद् & JUL. & HTCY & 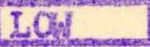 & AVERACS \\
\hline Whes? & 13.00 & 15.00 & 25.00 & 15.00 & 16.00 & 16.00 & 17.00 & 18.00 & 13.00 & 15.2 \\
\hline St5au & 3.50 & 3.50 & 3.50 & 3.00 & 3.00 & 3.00 & 3.00 & 5.00 & 2.50 & 3.45 \\
\hline Alfalia (Hay)(ory) & 10.00 & 10.00 & 10.00 & 20.00 & 20.00 & 10.00 & 20.00 & 10.00 & 20.00 & 10.00 \\
\hline Alialisa seed & 36.00 & 37.00 & 37.00 & 38.00 & 38.00 & 39.00 & 36.00 & 39.00 & 20.00 & 32.00 \\
\hline $\cos n(\operatorname{crs} n)$ & 9.00 & 9.00 & 9.00 & 9.00 & 30.00 & 10.00 & 20.00 & 12.00 & 9.00 & $9 \cdot 2$ \\
\hline Cottor (INat) & 80.00 & 80.00 & 80.00 & 80.00 & 80.00 & 80.00 & 200.00 & 100,00 & 76.00 & 89.8 \\
\hline Melons & $-\infty$ & reses & $-\infty=\infty$ & nowows & comenten & - noses & 8.00 & 26.00 & 5.00 & 8.5 \\
\hline Ploo & 25.00 & 25.00 & 26.00 & 35.00 & 35.00 & 30.00 & 30.00 & 35.00 & 23.00 & 26.2 \\
\hline Grapes (Frash) & menses & $-\infty$ & esersen & $-\infty$ & $-\infty$ & 20.00 & 10.00 & 30.00 & 20.00 & 1401. \\
\hline Gxopes (Dxy) & 50.00 & 80.00 & 85.00 & 90.00 & 85.00 & 80.00 & $\rightarrow$ & 1.20 .00 & 40.00 & $77 \cdot 5$ \\
\hline Mest (Best) & 45.00 & 45.00 & 45.00 & 50.00 & 45.00 & 45.00 & $4,0,00$ & 50.00 & 30.00 & 40.8 \\
\hline Hร des: Sheep & 30.00 & 35.00 & 40.00 & 40.00 & 40.00 & 40.00 & 40.00 & 40.00 & 10.00 & 36.1 \\
\hline Cow & 150.00 & 160.00 & 250.00 & $14,0,00$ & 150.00 & 150.00 & 150.00 & 150.00 & 50.00 & $144 \cdot 4$ \\
\hline CameI & 200.00 & 200,00 & 200.00 & 200.00 & 200.00 & 200.00 & 200.00 & 200.00 & 80.00 & 291.2 \\
\hline Woo2 & 50.00 & 65.00 & 60.00 & 60.00 & 60.00 & 60.00 & $160.00 \%$ & 160.00 & $4,0.00$ & 60.9 \\
\hline Blackeye Pass & 20.00 & 17.00 & 20.00 & 20.00 & 20.00 & 15.00 & 18.00 & 22.00 & 15.00 & 28.6 \\
\hline Potatoos & 20.00 & 10.00 & 22.00 & 18.00 & 20.00 & 20.00 & 10.00 & 20.00 & 6.00 & 10.5 \\
\hline WIntex Peas & 9.00 & 9.00 & 9.00 & 9.00 & 9.00 & 9.00 & 9.00 & 18.00 & 9.00 & 10.1 \\
\hline Mut่ton & 80.00 & 85.00 & 90.00 & $5.0,00$ & 80.00 & 80.00 & 70.00 & 90,00 & 60.00 & 73.0 \\
\hline Sheep 013 or Fats & 255.00 & 255.00 & $2 / 40,00$ & 260.00 & 155.00 & 130.00 & 140,00 & 170.00 & 90.00 & 123.7 \\
\hline Mu. $3 k$ & 24.000 & 16.00 & 14.00 & 14,00 & 14,00 & 14.00 & 16.00 & 16.00 & 10.00 & 12.9 \\
\hline Tonatoes & $-\infty$ & - & $=$ & $=$ & menem & 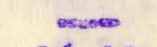 & 6,00 & 15.00 & 4.00 & 9.5 \\
\hline Oxlons & 14.00 & 16.00 & 24.00 & 24.00 & 8.00 & 16.00 & 4.00 & 16.00 & 4.00 & 10.7 \\
\hline Table Beets & 20.00 & 20.00 & 18.00 & 28.00 & 18.00 & coseser & samsers & 20.00 & 4000 & 16.3 \\
\hline Radjshas & .75 & .75 & .50 & $-\infty$ & $\infty$ & - ones & 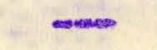 & 5.00 & 2.00 & 3.5 \\
\hline Caxrots & 4.00 & 3.00 & 4,00 & 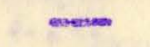 & $\infty$ & $=0$ & 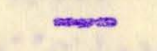 & 4.00 & 3.00 & 3.5 \\
\hline Iuxnips & 4.00 & 4.00 & 4.00 & $=$ & $=$ & $=$ & $-\infty$ & 4.00 & 2.00 & 3.2 \\
\hline Squasi & 3.00 & 4.00 & 400 & 5.00 & nestor & - & $\infty$ & 6.00 & 3.00 & 404 \\
\hline Cucumbet:s & 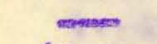 & $=0$ & exress & carses & 2.5002 & $.500 a$ & $.50 e a$ & 15.00 & 9.00 & 12.5 \\
\hline Cabbage & 60.00 & 60.00 & 40.00 & 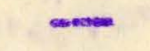 & $-\infty=\infty$ & 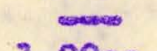 & - & 60.00 & 15.00 & 35.5 \\
\hline Egg Plant & nases & onsoss & 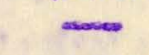 & $\infty$ & neses & 1.0002 & $.25 \mathrm{ea}$ & 6.60 & 10.00 & 9.3 \\
\hline Cauizacwes & $-\infty$ & mos & $-\infty$ & $\infty$ & $\infty$ & men & $-\infty$ & 130.00 & 80.00 & 208.0 \\
\hline
\end{tabular}

Washod \& clesned 


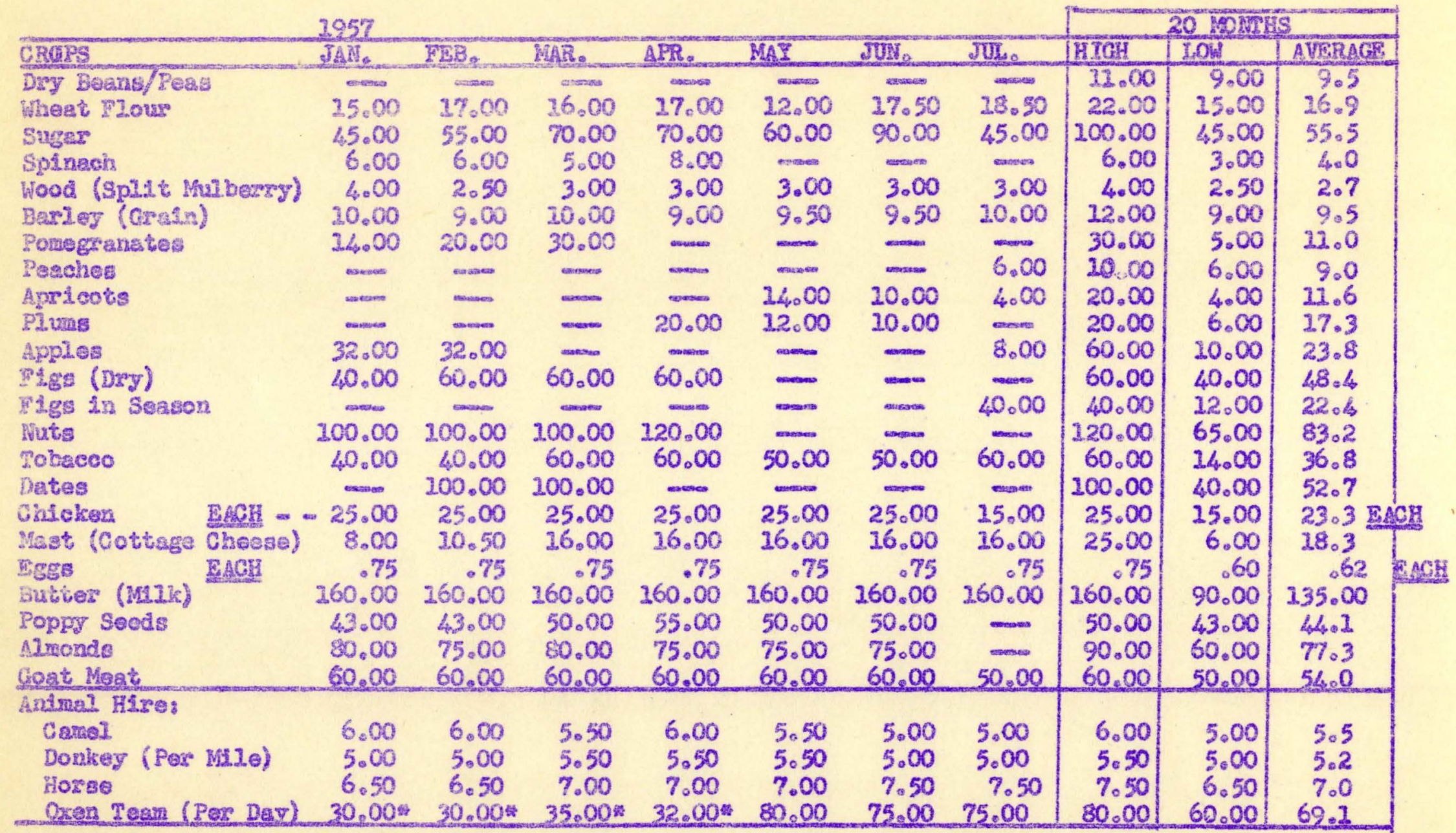

- Jas. April for 1 oxen only - other northe for 1 ox tean (2) plus dx1Fer. 
TAELE

14

December 20,1955

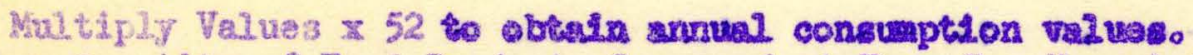

Avorege Qunarity of Food Products Consumed at Home Per Household Per Week by Nonferm Yenil10s. by Annuel Not Monex Income Class, United States, Spring 1962

\begin{tabular}{|c|c|c|c|c|}
\hline FOOD PRODUCRS & 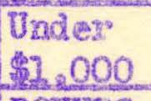 & $\begin{array}{r}\$ 1,000 \\
18,992 \\
19\end{array}$ & $\begin{array}{l}\$ 2,000- \\
\$ 2,999 \\
\end{array}$ & $\begin{array}{c}\$ 3,000 \text { orr } \\
\text { Over } \\
\end{array}$ \\
\hline Mojor Food groups: & POUNDS & POUNDS & POUNDS & POUNDS \\
\hline Milk (total equivalent, excluding butter).. & 18.6 & 27.2 & 29.3 & 33.6 \\
\hline 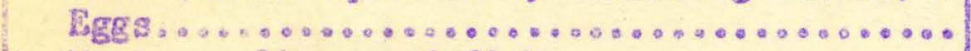 & 1.5 & 2.2 & 2.4 & 2.5 \\
\hline 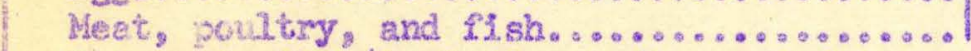 & 401. & 7.0 & 9.7 & 12.1 \\
\hline Fats and oils (including butter and fat euts & 3.2 & 3.8 & 3.8 & 402 \\
\hline 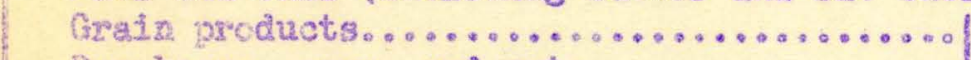 & 17.3 & 10.8 & 10.7 & 23.2 \\
\hline Dry beans, peas, and nuts................. & 1.2 & 1.2 & 1.0 & .8 \\
\hline Potatoes and sweetpotatoes.................. & 7.1 & 9.3 & 9.3 & 9.9 \\
\hline Gitrus frult and tomatoes.... & 408 & 7.9 & 12.6 & 15.0 \\
\hline Green and yellow vegetables... & 4.9 & 6.6 & 8.2 & 9.4 \\
\hline Other vegetables and frutt.... & 6.5 & 9.6 & 13.7 & 13.7 \\
\hline 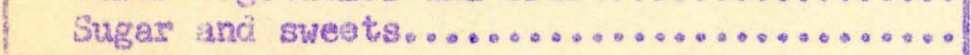 & 2.6 & 3.2 & 3.3 & 3.4 \\
\hline Selected products: & & & & \\
\hline Whole riik. & 10.7 & 17.3 & 20.7 & 23.0 \\
\hline Butter............. & 0.7 & 1.1 & 1.3 & 1.7 \\
\hline Bét............... & 1.3 & 2.4 & 3.4 & 402 \\
\hline Pork and lord & 2.8 & 3.0 & 3.2 & 3.5 \\
\hline
\end{tabular}

POTENT IAI, 0 , S. HUMAN CONSUMPT IOH. PER CAPITA

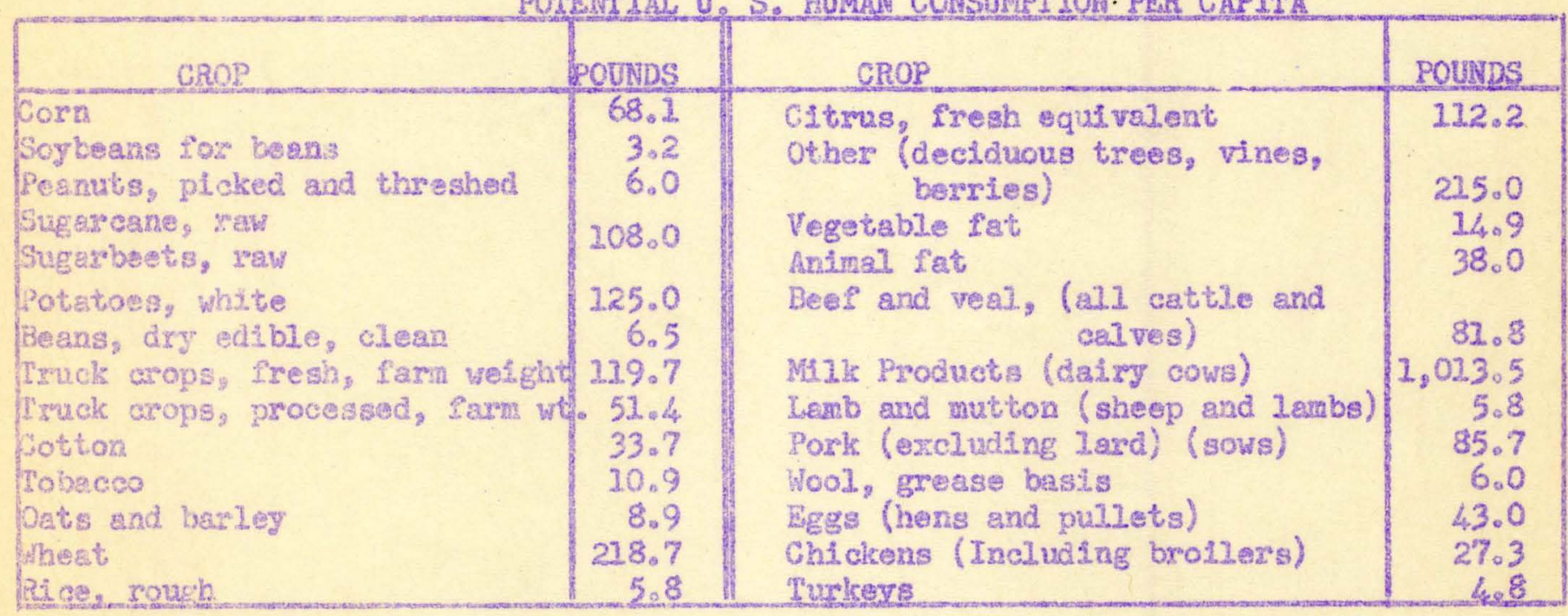


Fron a stuiy of rABLE 21. It can be secn that this dfot can only be ut111zed by those in the upper income brecket of about $3 \%$ of the population.

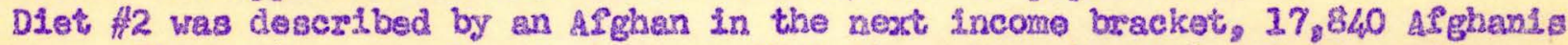
per year. It can be seen at onee howevor that the extrenely high calorie and protein Intake is unnecessexy. The oost also is much beyond the capacity of this in come. It is quite probable that this person, heving previously been on an alnogt wholly grain diet was reluctant to give up the extra "non" (bread) when he reached an lncome level which would allow the substitution of other foodso By geducing the amount of whost consumed to 1 pound per person per day the crlorles and protels 1s: take would be cut to about the proper figure and more money allowed for otber foods and for clothos and other necossities.

Diet $\# 3$ is that most comnon among sfghan laborers colng hard nanual lebor. Great alabs of $\mathrm{n}_{\text {non }}$ or whole grain bread are consuned each day. A 11 thle stow containing a swa3l amount of meat and vegotables is eaten in the evening. Tea, with or without augar, is the common drink when it cen be purchssed. Fresh fraft3, vegotables and rilk are not a regular part of the diet but ase eaten when obtainno able with 11 ttle or no cash outley. It can be seen that there 13 a $32 x g$ ealorie and proteln intake but that defletencles may occur $1 \mathrm{n}$ vitamin and nineral balance and types of food eloments. The cogt of such a diet is within reach of an ordine ary 1aborar earning 250-350 Afghanis per month whon supporting no more then one other person. However, even the highegt paid sk11led workers mugt depend on this diet or a lesser one when the number per family increases to five or more. Since the average earuings are estinated at oxly 3500 Afghanta per year and the steady vage earners repreaent probably $1 / 6$ of the total population, the average diet which can be afforded at $90 \%$ of gross earnings is .306 of that shown or represents 1650 eal. ories and 56 grams of protein per person per day. Food atatistics prepared by the United Nations ahow the following ealome and protein intake levels:

\begin{tabular}{|c|c|c|c|c|c|c|}
\hline India & 1620 & Cal. & $\&$ & 43 & guss. & protaln \\
\hline Indonesta & 1520 & 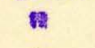 & n & 35 & $n$ & 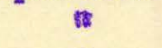 \\
\hline Ph1111pLngs & 2050 & te & * & 42 & * & n \\
\hline Japan & 2100 & $n$ & 经 & 54 & $n$ & ท \\
\hline U. S. Ao & 3250 & n & ต & 108 & it & : \\
\hline
\end{tabular}

Diet H4 Is that of the Everge U. S. non-farm population and requires $29 \%$ of U. S. average varnings. This may be compared to $90 \%$ of the avorage Afghan Income oxpended for a diot contalning only onowalf the calorie level. TABLE $U$, is included to show the proportionate use of various food and faxy products in the U. So

\section{ILing Sthandarda:}

TABC, 15 , sumurizes the comparative costs of the dlats show in TABLI, 12 and Wage Levels shown in TABLES 10 and 11 so as to reflect relative costs of llving, using food requirenents as the basis for compartson. Briefly the sturtion may be stated in this way. The avarage U. S. cit1.m, 11ving on a standard higher than most places in the wor2d, received $\$_{2} 400.00$ in 1955 of which he spent $29 \%$, ox $\$ 405.88$ for a 3250 -ealoz 10 diet containing 96 gxems of prom teln, 160 pounds of neat, and well balanced with respect to frulis, vegetables,

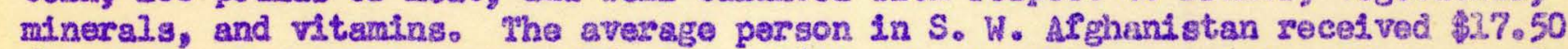
(at $40: 1$ ) of which bo apent $90 \%$, for a 1600 calorie diet contrining 55 graxa of proteln, 15 pounds of mest, and vory 11 tile fruits and vegetsbles. Over $90 \%$ of the onorgy and protoin was from snell grains. MInorals and vitaming and other food elenents were not wollebalsnced. 


\begin{tabular}{|c|c|c|c|c|c|c|c|c|c|}
\hline \multicolumn{4}{|c|}{ Per Capita Anmual cost of rood y } & \multicolumn{2}{|c|}{$\begin{array}{l}\text { Thage Earnings } \\
\text { Spent on Food } 2 /\end{array}$} & 9 & \multirow{3}{*}{ 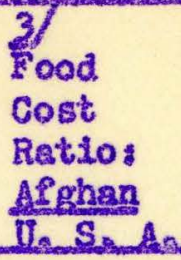 } & \multirow{3}{*}{$\begin{array}{l}\text { 4 Coat } \\
\text { of } \\
\text { L. Iving } \\
\text { Index: } \\
\text { Afghan } \\
\text { I. S. Salde }\end{array}$} & \multirow{3}{*}{$\begin{array}{l}\text { Type } \\
\text { of } \\
\text { Dset } \\
\text { (raBLS }\end{array}$} \\
\hline Asghanist & Prices & 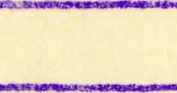 & \multirow{2}{*}{$\begin{array}{l}\text { Stateajic } \\
\text { Cogt of } \\
\text { Same } \\
\text { Food }\end{array}$} & \multirow{2}{*}{$\begin{array}{l}\text { Single } \\
\text { Arghan } \\
\text { Worker }\end{array}$} & \multirow{2}{*}{$\begin{array}{l}\text { Por } \\
\text { Caplts } \\
\text { Afghen }\end{array}$} & \multirow{2}{*}{$\begin{array}{l}\text { Per } \\
\text { Captta } \\
\text { U.S. As. }\end{array}$} & & & \\
\hline Afghanis & $\begin{array}{l}\text { Do11ars } \\
27.27 .1\end{array}$ & $\begin{array}{l}\text { Do.11ars } \\
60.2\end{array}$ & & & & & & & \\
\hline Afs. & 战 & $\$$ & & $\%$ & $\$$ & 8 & & & \\
\hline 2556 & 120.09 & 63.52 & 329.38 & 73.02 & 365.0 & 22.87 & 0.287 & 16.2 & 12 \\
\hline 2594 & 121.22 & 65.33 & $339 .<5$ & 74.21 & 372.0 & $21 \mathrm{H}_{2} 25$ & 0.276 & 1582 & 12 \\
\hline 1989 & 93.44 & 48.92 & 100.38 & 56.83 & 284.0 & 7.27 & 0.709 & 60,2 & 4 \\
\hline 3667 & 177.92 & 21.25 & 205.88 & 204.77 & 52420 & $\sqrt{29.006}$ & 0.234 & $18: 3$ & H4 \\
\hline 630 & 29.60 & 35.50 & 31.79 & 18.00 & $\overline{s 0.0}$ & 2.27 & 0.709 & 40.2 & 45 \\
\hline
\end{tabular}

I/ Based on 1953 es5 basar prices in Afghenistan and retail grocery prices in the Untted States.

2 A single Afghan worker supporting no family can afford a balanced diet at about $75 \%$ of his vage arzings. 2he per capita income will allow at $90 \%$ of the incone, low (1600) calorie, moderete protein (56 grems), diet eonem sisting alnost wholly of gxain produets. The Afghan cogts for thin diet and statestde cogts for average U. S. diet are shown in hesvy outilne above.

$3 /$ Based on cost of sood at each location adjusting exchenge retio to 31 Afohanis 1 Dollax.

4/ Ratio of porcent of por capita incone required to purchase equivalent quartitios of food. 


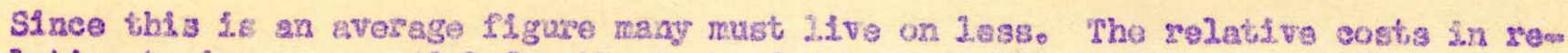
Iation to Income axe $40: 2$ for the type of diet which the Afghan per capits wago oarnings can buy. Only single Afghan workers supporting no famil1es can aftord a balaneed diet such 23 /2 in TARLE 12 . The mumber of such alngle workers is

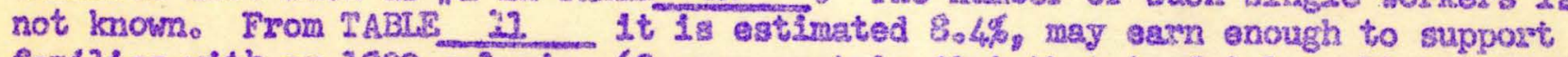

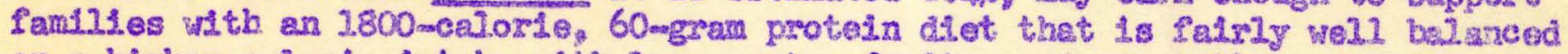
or a higher celorle intale whth 103 moats, frutts, and vegetablos. Another 3.2\% can afford for thelx familisa a wall belanced 2200mcalort, 73 -gram proteln, diet which $1 \mathrm{~s}$ well. In 1 Ine with the internetionel stancierd recomendations of $2500-2600$ calortes and 65 grams of protein as avexage. Less than $1 \%$ can 11 ve sxtremely woll and feed thestr fantlies a wide cholee of wall balanced soodso

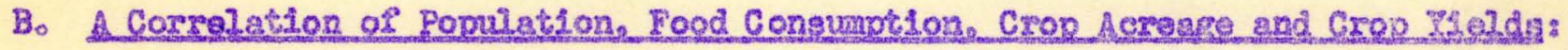

In TABLs 26 , an attempt has besn made to projost present and potont.1al food congumption in terms of the anmul denard Lor various agrieultural products. At present grein products are about $66 \%$ by welght of all food products consumed and $82 \%$ of ald solld foods (Fogetables excepted). A change of living standards to 213.\% a normal calorie and proteln Intake and balanced diet for $90 \%$ of the poople would Increase the consumption of graln products by only $4.21 \%$ but would j.nerease the total Iood consunption by $283 \%$.

In the study of dLets among farmers, Laborers and tomnspople of the Kandahar ares It wes found, ss shorn above, that nearly $80 \%$ of the population consun a dLet alnost wholly of gralns with smell. quantit1os of Ixufts, vogetables and mosts at as? average level of 1650 caloxtes and 56 grams of proteln dally. Whils atngle woritars

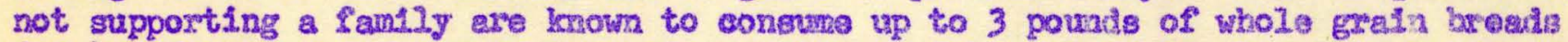
(non) dafly the average of all workers and non-workers is nearer one pound. This $1 \mathrm{a}$ based on observations and mersurenents of difots and compar1son of the natlonel laboz income estimated at an average of 3500 Afghenis par annum with food prices (195455).

Preaent wheat production has been verlously estimatod at 7.5 bushols (Tudor Commttee) 8.3 bu. (average of Stage 1, 1953 Halmand Valley Report and 10 (1955 Report on production Increases in the Helmand Valley).

Acreages In all crops was estimated for the grote irrelgable astrea of $1,158,500$ acres shown on Map LDm $17=$ R4 as 420,000 acres in 1956. Vary 11tt1e graln products appear to bo exported or Ixparted. There is movenent bitween towns within is provis ince and some botween provinces in yoars of low yield. In genera, housver, greins produced within the watorshed are consumed these.

If we asgume that the population of S. W. Afghantatan is $3,000,000$ and avexage whole grasn consuption is near $1 / 4$ per day, 602,540 tons mast be consuned annualiy。 Allowing for seed and for $10 \%$ wastage this wovid require, at the ogtimated lavel of 7.5 bushals par acre (Tudor roport), roughly $2,950,000$ acres. This 1. 24 thes

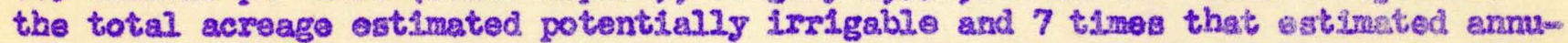
aliy cultivated In the development area. To produoe the above atount an the $4,20,000$ acrsa estinated prosentiy Iarnod In the Helmand-Arghandab aree would regulrs a prea duction of 52.5 bushelif acre. Since the par caplta food consumption flgure 1 well

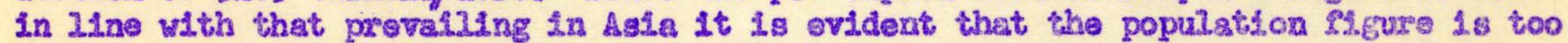
high. All studies Indiate lass than 500,000 aeros prodineing whot in all of tho Helnand-Axghandab areas murveyed or authorized for gurvey. Tho uppor grarnak, upper Arghastan and 211 small upper velloys of tho entire chakensus basin watorshed could

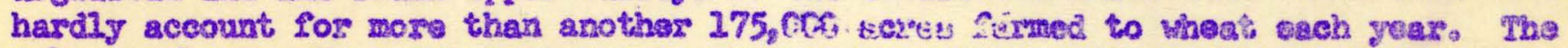
oniy concluston thet can bo drawn 1s that the popilation IIgure of 3,000,000 18 too higho A IIgrase sonewhare noax $1,500,000$ would bs more reasonabla. 


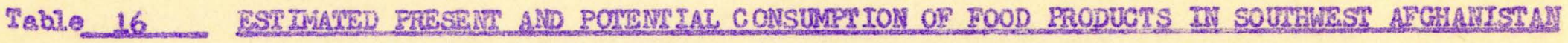

\begin{tabular}{|c|c|c|c|c|c|c|c|c|}
\hline Food Itern & D10 & D104 & Diot & 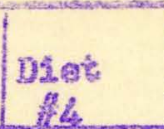 & Dise & $\begin{array}{l}\text { Anmual I } \\
\text { Present } \\
\text { Consumption gong }\end{array}$ & \multicolumn{2}{|c|}{ 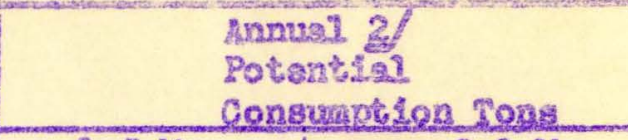 } \\
\hline $\begin{array}{l}17 \text { Use satio } \\
\text { pressut }\end{array}$ & 0.0323 & 0.0841 & 0.0875 & 0.0093 & 0.7880 & $\begin{array}{l}\text { I, } 500_{2}, 000 \\
\text { Population }\end{array}$ & $\begin{array}{c}1.5 \mathrm{IL} \\
\text { Population }\end{array}$ & $\begin{array}{c}3.0 \mathrm{M} \\
\text { Ponylation }\end{array}$ \\
\hline What & 0.750 & 0.750 & 2.00 & 0.450 & 0.615 & 205,360 & 232.320 & 162,640 \\
\hline Bice & 0.25 & 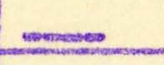 & $=$ & 0.040 & 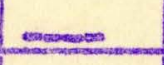 & 1.370 & 21,630 & 43.260 \\
\hline Corrs. & 0.20 & 0.25 & 2.00 & 0.002 & 0.306 & 96.610 & 51.650 & 323,300 \\
\hline Fruits & 1.00 & 0.70 & - & 0.667 & $=$ & 26.335 & 212.620 & 425,240 \\
\hline Meat & 0.20 & 0.12 & 0.120 & 0.466 & 0.037 & 16.450 & 49,460 & 98,880 \\
\hline M215 & 0.90 & 0.28 & - & 1.35 & soreas & 10,000 & 175,000 & 350,000 \\
\hline Fats \& 0170 & 0.20 & 0.05 & 0.005 & 0.275 & 0.002 & 3.570 & 22.720 & 45,440 \\
\hline Vegetables & 2.00 & 1.00 & 0.50 & 0.778 & 0.153 & 87,000 & $39 \%, 000$ & $782_{2} 000$ \\
\hline Sugar: & $(\mathrm{ngg})$ & 0.016 & seseses & 0.252 & - & 770 & 35.800 & 21,602 : \\
\hline Eggs & 0.05 & 0.05 & noseses & 0.120 & $=$ & 8.550 & $39,4.0$ & 76.880 素 \\
\hline $\begin{array}{r}\text { Boan } \\
\text { Dried Poss \& }\end{array}$ & $($ nego $)$ & $m$ & 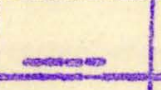 & 0.030 & soseses & 80 & 112300 & $23.600=$ \\
\hline Nucs & $($ ges, $)$ & $=$ & -1 & 0.026 & naseose & 45 & 2,000 & $2000=$ \\
\hline Rotatoes & (neg) & soseses & -5 & 0.428 & - & 1,200 & 58,600 & $217.200=$ \\
\hline Potential & 0.50 & 0.30 & 0.30 & 0.30 & soss & 6532910 & 2.291 .500 & 2.583 .000 \\
\hline I" $\mathrm{FaO}$ & 5.25 & 3.376 & 3.625 & 4064 & 1.793 & 155 & & \\
\hline
\end{tabular}

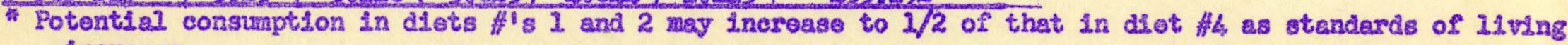
Incraase. 


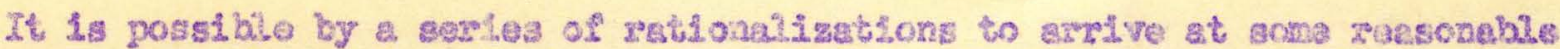
egresuent anong the various sactors of population, food congunpton, food producu

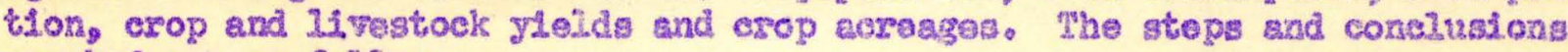
reached are as follows:

1. Suxveys and measurenents of survey maps and acrial. photos give a folriy reliable pleture of orchards, vinegardis and other esop lands lor the Arghendab, Helnand Valley and Chakansur arbas belos the two resarvolrs. This figure was uaed as a bast for projection to other loss kom araas. Acroages agreod fairly well

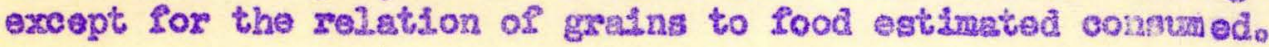

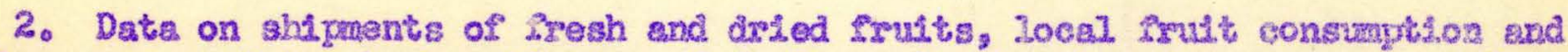
spollage vas used to chock ost1mates of frult production based on acreages and previously asmuna yields. The aeroages and ylelds wore adjusted to agrea fairl7 woll whth the above data.

3. Redueing the population flgure to $2,500,000$ another bertes of comparipons

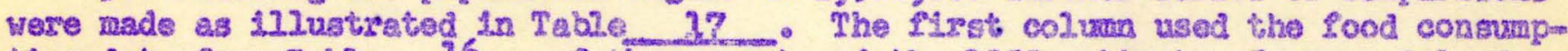

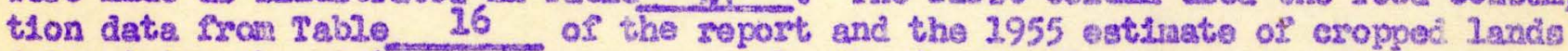
determining the rields nocoswary to wupply the foodstuffs consumed. It ean be readily wan that grain yiolds axe ontrely too high and treo and vine frult ylelds too low. Spollage and exports wrre not 1nclucled, however".

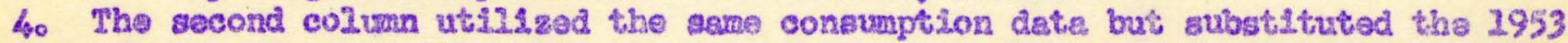

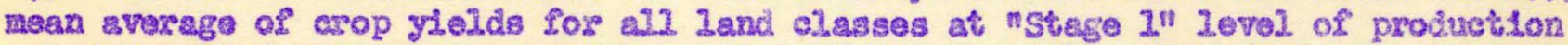
and detarnhnd the acreage necessery to feed $1.5 \mathrm{M}$ poopl.e. Tho of oach land clase

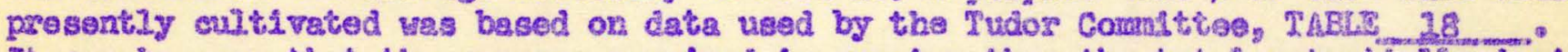

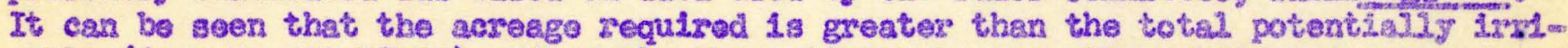

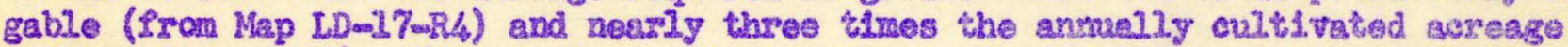
estimated for 1956. It Is quito evident additional edfustmenta are needed to zoconolle the various detao

5. In the 1ast columen the ylelds of al cryps have been adjugted to those ragt comionly observed. The low ylalds assumed for gralne in past astimatos bas regu?t

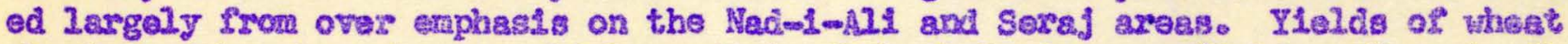
about Kanciahar have boen as high as 40 to 50 bushel. in many 11.

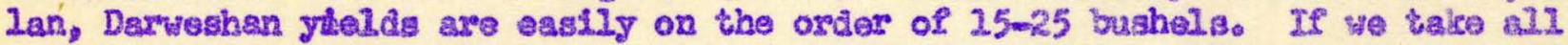
solis and places throughout the watershed Pron Chakansur to elevation abovs 10,000 foot, sonewhere neas the upper 1 inft for wheat, it is not unreasonabie to aseurat a 15 bushal average. Orchard and vineyard ylelds axe adjugtod to the typos of

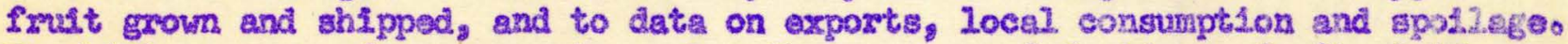

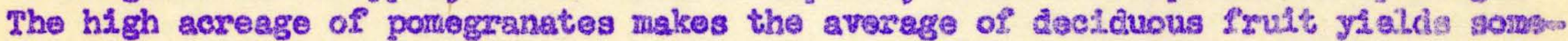
what higho Ilelds of other crops appear to be in IIne with observations ovor ulde aress. Acreages of orcharda, and vinoyards have bsen expanded on a roduegd pest centage basls Irom Helmande-Arghandab datis. The percentage of leguras has baen held about the samo. The acresges of other crops have slraply boen computed as those aeeded to produce foodstufir estimated conaumede.

These sevaral adjugtments 1 in data are all subject to modifleation as na lacts

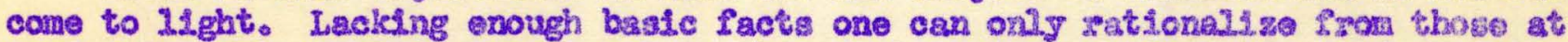

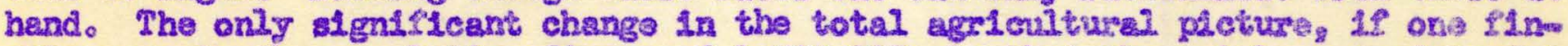

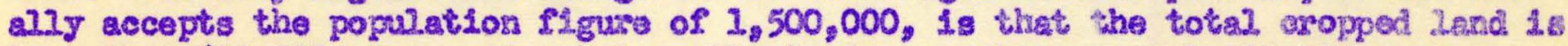
less than 800,000 acrea and totel axable lands sonewhore nas 1,500,000 acres. Very fow small watersheda and upper valleys have boen exanined but one when travale Ing through can observe nuxaroug patchos of gxaln and other crops seattered throughout thase upper: areas. 
Tablo 19

A COMPARISON OF MEXHODS OF ESTIMATING

CROP ACREAGES AND CROP YIFTDS

S. Wo AFGHANISTAN

$7 / 27 / 57$

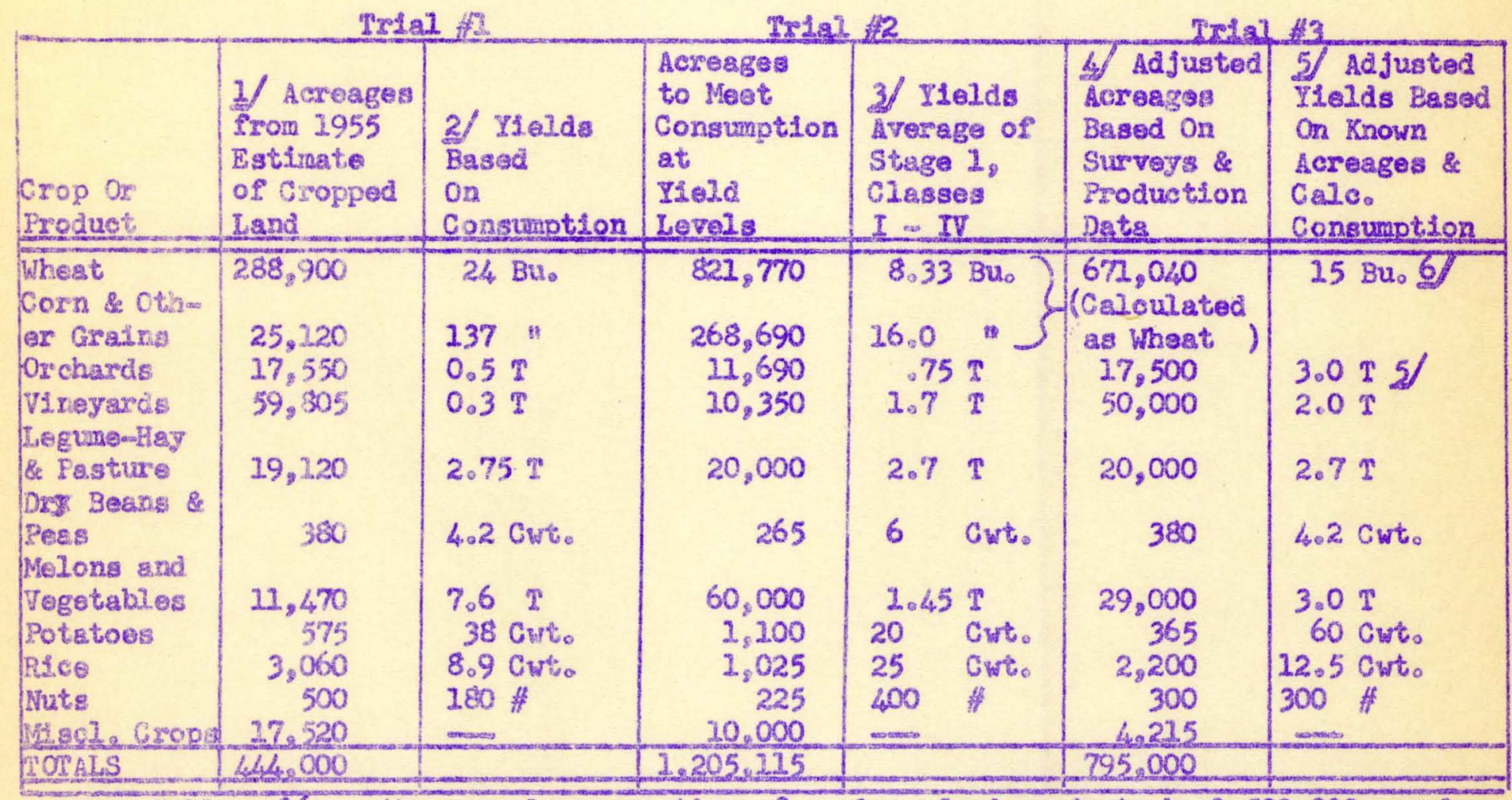

F From Teble 16 the annuel consumption of various food products by $1,500,000$ people at a glven diet lovel furmishes control deta for calculations of acreages and ylelds。

I/ Report of July 7, 1956 to $3 \%$. W. Morrison on acresge annually farmed in Helmand Arghan dab watershedis is estinated seres in other areas from Drawing LDe-17 R4.

2/ Yialds cale. Consunption from Table 16 divided by acres.

3 Yle.lda are a welghted mean of Stage I for all i classes of land. The \% of each wow cropped in neasured projects 1s as follows: Class I $-24,49 \%$ Class II $-31.60 \%$ C1ass III - $29.92 \%$ and Class IV $-13.98 \%$. Note that the acreage 1s then determined by dividing groos consumption by yields.

If The adjusted acreages for all but grain crops are based on expanding the data from survayed projects proportionally to the total 1rrtigated acrage shown on Drasing LD-17 Rh but meking orcherd and vizeyard percentages equal so Helnend Valley。 The acreage of grains 1 bssed on an asswwed grain yield equivalont to 15 bushels per acre of wheat。

5/ The yleids of orchards and vingyards include adjustments for exports and 20-30\% losses in handling. Fonegrenate acreages and yields boost the tonnage for orchaxds。 Other crop yields are approximeted from known date.

6f The Tudor Gormittee estimatad 602,000 people withis the Helmand Valiey development area. Assuming this area lincludes all authorizod and potentil projeots from the two dans to the Chakenaurs the total Lxrygated land messured froro surveys 1 about 315,000 acres and gretn acreage 25 about 235,000 . The calculated yleid necessary is 17.2 bushela per acre for a 1650 ealorle diet. Trudor sstimated an average of 7.5 bushel: per acre which wovld provide only a 720 calorie diet. This is obriously too low and,

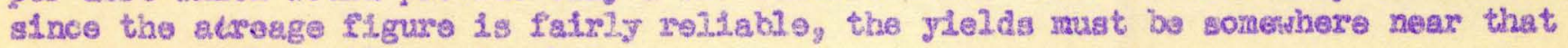
assumed for the entise watarkhedo 


\section{1}

Table 18

ADJUSTED PERCENTACE AND ACEES

$7 / 28 / 57$

IV CROFS FOR ARGAS NON IRRTGATED AND

PEACHABIE BY HITWMAND-ARCHANDAB WATER

\begin{tabular}{|c|c|c|c|c|c|}
\hline \multirow{3}{*}{ GROP } & \multirow{3}{*}{$\begin{array}{c}\% \\
\text { TOSAI }\end{array}$} & \multicolumn{4}{|c|}{ 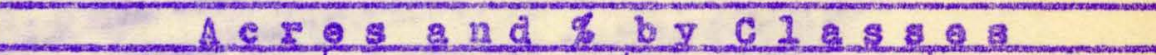 } \\
\hline & & $I$ & II & III & IV \\
\hline & & 24,19 & 31.60 & 29.92 & 13.98 \\
\hline Orehardis & 4.58 & 17,000 & 500 & cossus & nanemos \\
\hline Vineyards & 13.08 & 25,000 & 20,000 & 5,000 & mans \\
\hline Wheat & 63.07 & 33,333 & 78,468 & 37,585 & 42,817 \\
\hline A. Pa:2: Hay & 5.00 & 3,500 & 4850 & 48535 & 5,580 \\
\hline Vegetrables & 6.5 & 6,000 & 7,950 & $7,4<0$ & 3.475 \\
\hline Beans & 0.10 & 80 & 105 & 343 & $-\infty$ \\
\hline foren & 5.0 & 6,700 & 6,000 & 5,900 & 600 \\
\hline Rice & 0.80 & 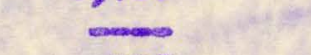 & 500 & 1,500 & 1,060 \\
\hline Potatoes & 0.35 & 225 & 200 & 150 & mensemses \\
\hline Muts & 0.10 & 150 & 120 & 110 & ascosons \\
\hline Cotton & .75 & 735 & 950 & 900 & 415 \\
\hline bthes crops & -1.00 & -935 & $-1,230$ & $\frac{1}{2} 40$ & 539 \\
\hline Totas & 700 & 96.658 & 220,853 & 1140.03 & 53867 \\
\hline
\end{tabular}

Fotal Cultivated 382,390 Acras 
Most of the data so far presented on acreages has been based on surveys of the HeIrand and Arghandab projects below and within comnand of the two dans and the general Helnand Valley Darelopant program. Thoso 13 generally below the fonthilis and nountein ganges. Not all of this area has been studied. It is reascnable to assume that the innumerable small tracts of arable lands Iying In the upper reaches nay bring the watershed totals to somewhere near the figures raeched by the 18tional mothods discussed abovo. If nots the population I1 mure wij] need Iurther reduction.

\section{Livostock Produotion and Ifrostock Products:}

LA vastock and II.vostock products congtitute a major source of Income and are not restiketed to irrigated lands. Sone jetLonelization is nesessary, however, to produse reasonable agreoment anong the various data available on 11 vestock production. A 1953 raport of the MAnistry of Agriculture shows the livestock data quoted In the following table. Prices of various 11vestock products and rates of animal hire are from Kandahar Bazar and farm market prices whleh have baen sampl-o od montily over a two year period.

The total exra draining Into the HeImend ginks (Chaikangur-SLesten Area) is astimated at 125,000 square miles or roughly one-half of the country. 0 this area provious ostimates indiested about 42,000 square miles as range lands, 4,000 square whles of stream valleyt and 15,000 square mlles of aand desert (Reglatan). The rest was constdered rolathvaly too barren, rugged or high for productive use.

If we assume that roughly $1 / 3$ to $1 / 4$ of the livestock are in this one-hals of the country, the foljouring rationalization may be made as to foed and Ivestock product:Ln:

1. Assuming a normel ratio for graging computations of 5 sheep or goats to 1 cow or horse there wowld be $8,000,000$ sheep and gosts f 5 times $1,125,000$ aheep equivilents in terms of boxes, cows, conkeys and canels of a gross of $13,625,000$ sherp units. With $2,000,000$ slaughtered each year this leaves an avarage of $12,625,000$ per gear zound graking sineo 1ittile other foed is avallable.

2. It has been dotermined by verious sources that about $80-90$ mannd.s of dxy feed are nscessary for one sheep one year. A requirenent of 800 \# used in this celeriationo

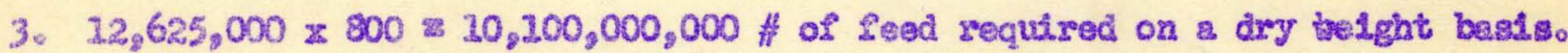

4. Sources are estimsted as follous:

$$
\begin{aligned}
& 1,000,000 \text { acres valley grass and brugh lands 0. } 1,000 \mathrm{H}=1,000,000,000 \text { \# } \\
& 250,000 \text { wheat stubble \& gtraw } 1,000 \text { \# }=250,000,000 \text { \# }
\end{aligned}
$$

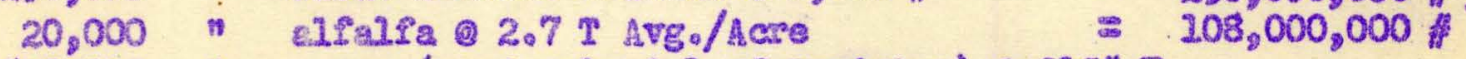

$$
\begin{aligned}
& 27,840,000 \text { " range (used oniy } 0.1 \text { of Regigtan) (2315\% } \\
& 8,742,000,000
\end{aligned}
$$

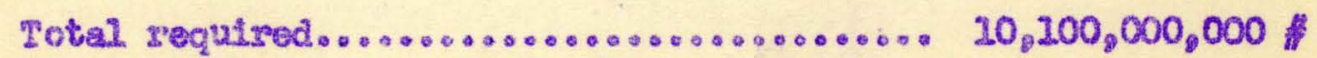

(1/ Whest straw 2: alzo vaed for brick malking, fuel and bodalng)。 


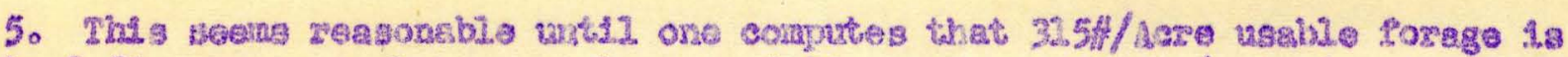

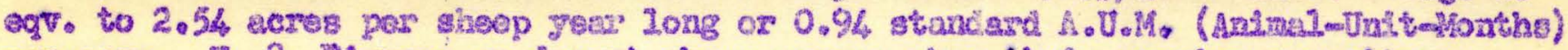

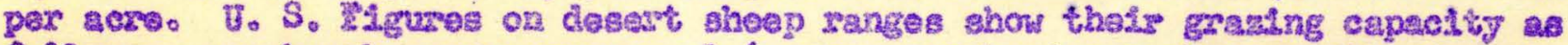
Soliows sagebrush grass ranges -1.6 acres per head par shoep-nonth, desert

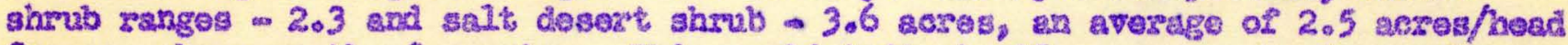

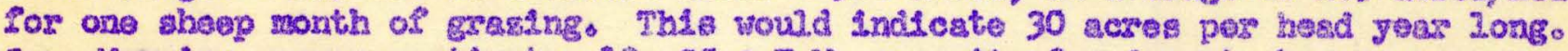

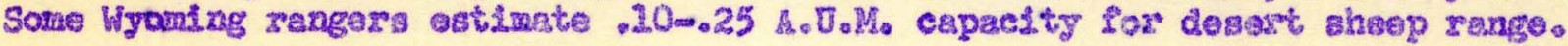

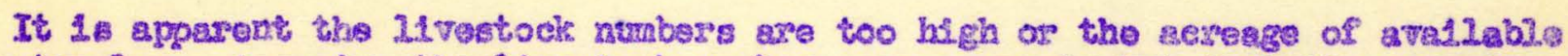
range too 20\%. Assuning the livestock mubers are corsect, but thet the carrying

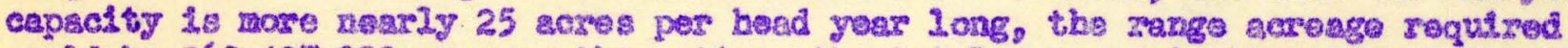
would be $263,437,000$ or over thrre timos the total sorage in the viaterehod. Since

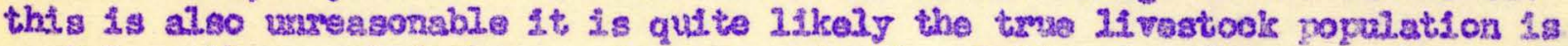

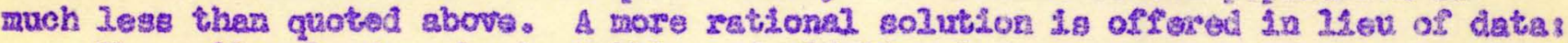

The valley 2 sais, witeat stubble and alfalfa clovor pastures ean suppors st

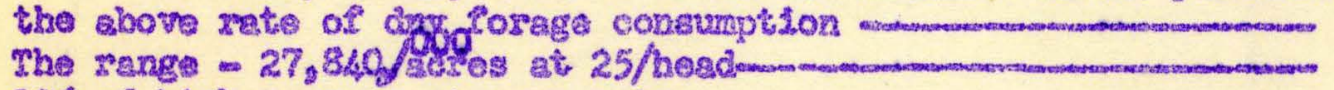
$10 \%$ of higios arese at seme zatem

$$
\frac{1,697,000}{1,213,600} \frac{182,600}{3,000,000} \text { n }
$$

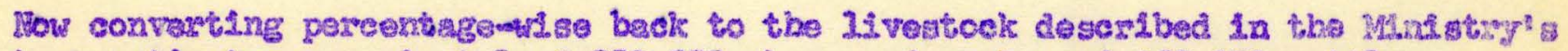

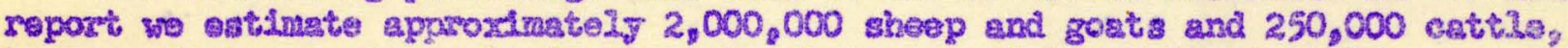

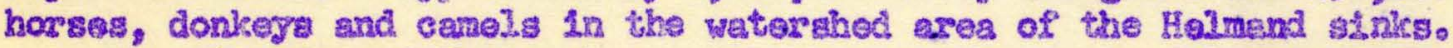

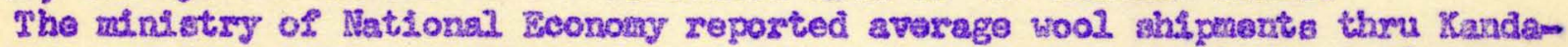

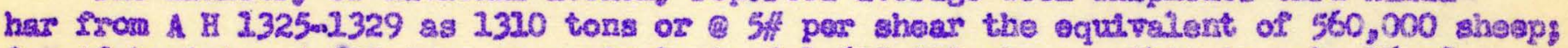

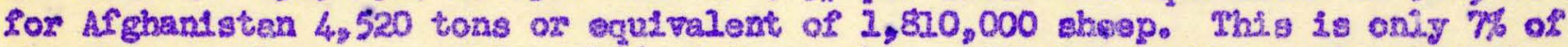

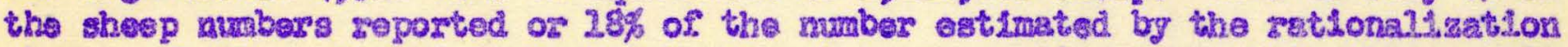

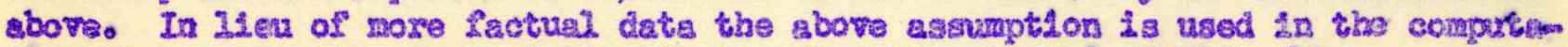

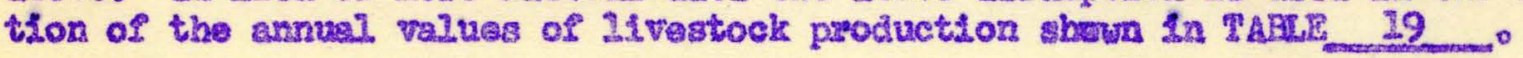

\section{Srmary and Conclustors:}

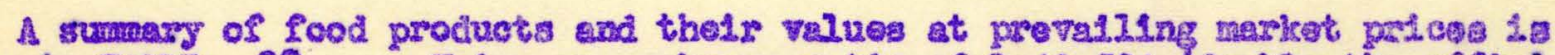

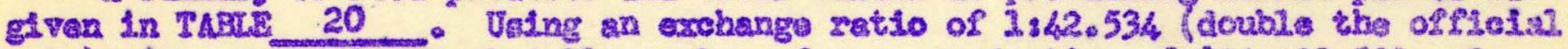
rate) gtros a total anmual dollax value of erop productlon of $24,400,800$. To

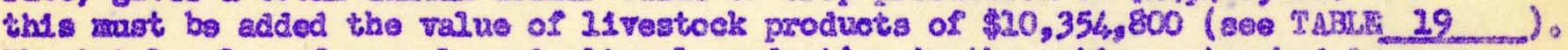

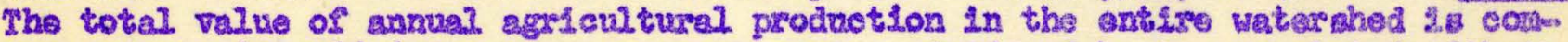
puted to bo $34,766,600$. The per captie value of 985 Afghad a coxrelates vith the

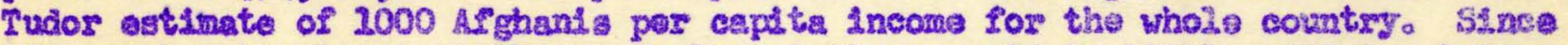

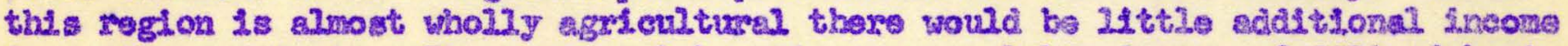

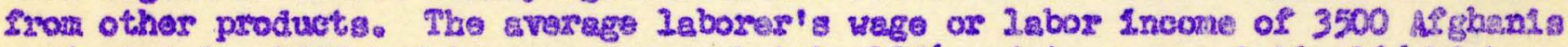
artinated for 1955 had Lnereesed sonewhst by 1956 and 1 aow probably 10 \% highet than the 1955 Ievel. Correspondingly food prices for 1957 are sbout $20 \%$ bigher

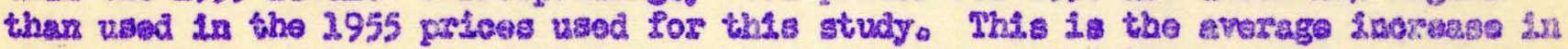
bsreas prices of 12 baste food 1teans. The general cogt of Living ratso protably bas not whifted matex'alis.

In concluston, it mat bo pointed out tbat these rationalisetions may not bo truly factual but are the bagt approach to a zeasonable pleture of present agrel cu?

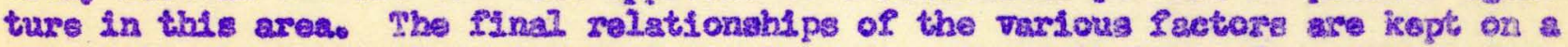

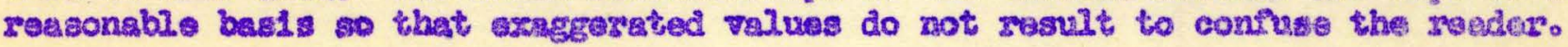




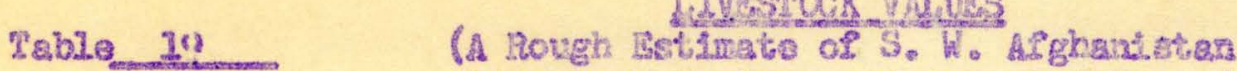
IIVostoek Numbers and Anmues Value of $7 / 27 / 5 \%$ L1 vestocls Products)

I Datas Afghanstsan - (1953 Revort of Min. of Agriculture) $25,000,000$ shoep and goats (1/5 goats)

$5,000,000$ Gamel., donkeys, borasos \& eattio $4,000,000$ Kerakut sheep

$8,000,000$ Sheep \& Coats alaughtored

$1,000,000$ Hides exported

II Calculgtions for All Afghanistian using above dats

\begin{tabular}{|c|c|}
\hline Itrem & Un't Value \\
\hline Hades: & Afphans: \\
\hline Sheep & 30 oach \\
\hline Catt]e & 133 \\
\hline Camal & 277 \\
\hline Horse & 150 \\
\hline Donlesy & 50 \\
\hline
\end{tabular}
ouents ty

Wool:

60 Md。

$$
\begin{array}{r}
8,000,000 \\
250,000 \\
50,000 \\
25,000 \\
-9,104
\end{array}
$$

Totel Value H? dea (Nots: Wool expt. 1947-a1951, 5andro Avg.)

Mege, Eegs, Milk \& Cheese:

\begin{tabular}{lr}
\hline Beef & $40 \mathrm{Md}$ \\
Mutton & 50 \\
Sheep & 70 \\
Sheep Fat & 116 \\
Chicken & 27 \\
Eggs & 0.74 \\
Cheese & 16 \\
Milk & 13.0
\end{tabular}

Total Meat, Eggs, ML1k \& Chsoso

\section{Animal Hire:}

Camele 6 Af/mile $\times 100,000 \times 250 \times$ m.

Donkey 5 क $5500,000 \times 100$ "

Horse 6.5 x $100,000 \times 300$ "

Ox Tmo 40 dasy $\times 500,000 \times 50$ days

Total Valuo Antwal Hire

Gross Annual Afghand Value

of Iivegtock Products

\$alue 승 21.267 = \$1.00

\$VIue 상 42.534 $\$ 2.00$

* Excludes Karakul shep grown In Northorn \& Eastem ASghanistan Total Velue $240,000,000$

$33,250,000$

$8,850,000$

3.750 .000

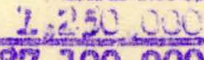

$287_{2} 100,000$

$450,000,000$

$(54,252,000$

$\checkmark \log _{2} 2500$

$300,000,000$

$=600,000,000$

$=2,575,000,000$

$580,000,000$

- $135,000,000$

$=177,600,000$

* $32,000,000$

: $312,000,000$

$=3,711,600,000$

$=150,000,000$

$250,500,000$

$=200,000,000$

$=1,000,000,000$

$=\frac{1}{3,600,000,000}$

$6,048,700,000$

$284,437,200$

$142,208,500$

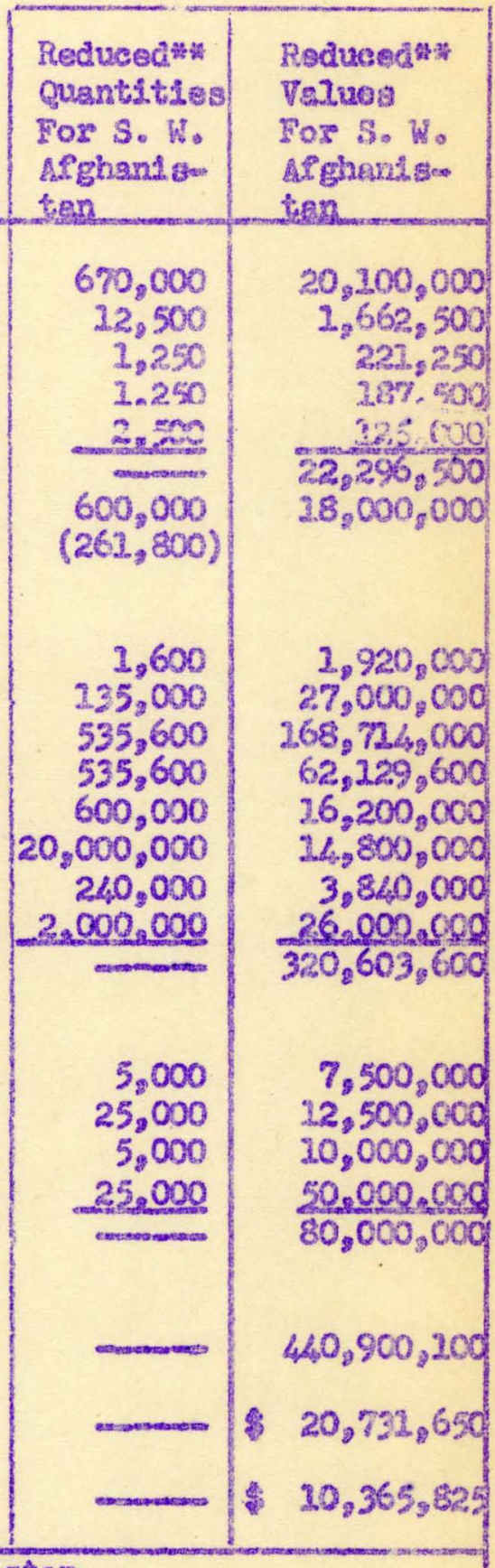

** Based on relationship of arailabla foed to aninal requirements and the screage carl carrying capacity of renge lands in $\mathrm{s}$. W. Afghanistan. 
Tabie 20

EST TMATED PRESENT PRODUCTTON AND

YALUIE OF CROPS GROWN IN $S$. $W$. AFGHANISTAN 1

$7 / 27 / 57$

\begin{tabular}{|c|c|c|c|c|c|}
\hline \multicolumn{2}{|c|}{ Grop } & $\begin{array}{l}\text { Tiolds } \\
\text { in Tons }\end{array}$ & $\begin{array}{l}\text { Price In } \\
\text { Afghanis/Md. }\end{array}$ & $\begin{array}{l}\text { Convergion } \\
\text { Af/ } / 42.534: 1\end{array}$ & $\begin{array}{l}\text { Gross Value } \\
\text { in Dollare }\end{array}$ \\
\hline \multirow{8}{*}{\multicolumn{2}{|c|}{ 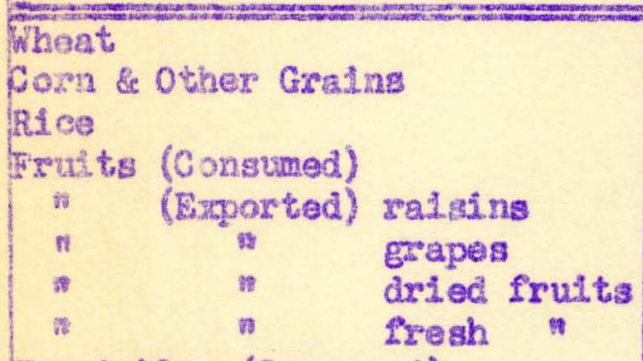 }} & 205,360 & & .02351 & $11,587,230$ \\
\hline & & 96,610 & 8 & & $6,645,370$ \\
\hline & & 1,370 & 24 & ${ }^{n}$ & 154,600 \\
\hline & & 26,335 & 30 & $n$ & $1,238,270$ \\
\hline & & 6,504 & 50 & $n$ & $2,4,84,160$ \\
\hline & & 4,250 & 15 & $"$ & 299,750 \\
\hline & & 1,303 & 60 & $n$ & 395,700 \\
\hline & & 3,824 & 10 & " & 179,800 \\
\hline \multirow{3}{*}{\multicolumn{2}{|c|}{$\begin{array}{lc}\text { Vegetables } & \text { (Consusad) } \\
\text { Lentils } & n \\
w & \text { (Exported) }\end{array}$}} & 87,000 & 3 & $\pi$ & $1,227,220$ \\
\hline & & & 14 & $"$ & 5,270 \\
\hline & & 18 & 19 & " & 1,520 \\
\hline \multirow{2}{*}{\multicolumn{2}{|c|}{$\begin{array}{l}\text { Nuts (Consumed) } \\
\text { Potatoes (Consumed) }\end{array}$}} & 45 & 90 & " & 19,040 \\
\hline & & 1,100 & 10 & 解 & 51,720 \\
\hline \multicolumn{2}{|c|}{ 2. Poppy sead (Exported) } & 68 & 50 & $n$ & 15,990 \\
\hline \multicolumn{2}{|c|}{ Alfelfa soed : } & 21. & 10 & $"$ & 990 \\
\hline \multicolumn{2}{|c|}{ 2/ Tobaces } & 95 & 45 & $n$ & 20,100 \\
\hline 3/ Cotton & ต & 253 & 80 & " & 57,400 \\
\hline \multicolumn{2}{|l|}{$2 / \operatorname{comin} n$} & $n$ & (50) & $\omega$ & 16,690 \\
\hline \multicolumn{2}{|l|}{$\begin{array}{l}\text { COTAL ALL GROPS } \\
\text { AVERACE GLL CROPS }\end{array}$} & $\begin{array}{l}4348307 \\
0.54670\end{array}$ & & & $\begin{array}{l}24,400,820 \\
=830.69 / \mathrm{AS} \\
\end{array}$ \\
\hline
\end{tabular}

If Estimates based on ratio of populetion and food consumption to available acreage and

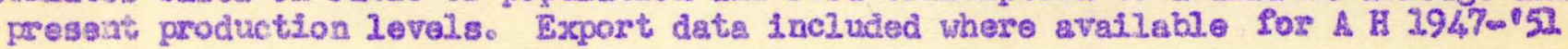

2) Local consuaption not estsmated. Shipnents through Herat, Channn \& Rsbul not ave1]able on exported 1terms.

3 Cotton astimated at $1 / 10$ of hf ghantstan exports.

NOTE: This is $16.4 \%$ of the value of national agricultural products for 1953-154 as show in the Tudor Report. 
It bas bean nccessary in arriving at these final figures to:

1. Reduce the previously eacimated poprilation of $3,000,000$ to $1 / 2$ or $1,500,000$ 。

2. Recuce the IIvastock population previously ostinated at $8,000,000$ sheap and goats and $1,125,000$ other 11vestook to about $1 / 4$ or $2,000,000$ sheep and goats and 250,000 othes anduel.

3. Increase the total presently cropped acres by 1.89 times the 1955 estimate sade for the Helmand-arghandab developnent area.

4. Incresse the estinate of average grain yields to the equivalent of 15 bushels of whest par scre.

A grmwary of erop production and crop values from all U. S. Fodaral Reclamation grojectis for the year $1955 \mathrm{is}$ included for comparian. It w111. be notad thet the present level of gross erop income per gere of the Helmand area is only $1 / 27$ thet of the Coschelle Valley and $1 / 8$ that of the averege of all districts In $\mathrm{S}$. W. Artzona and Southern Calsfornia (axess of sirsilar clinate). The Columbia Basin Broject, a reletivaly now area with about 150,000 aeres exoppod in 1955, had nearily 4 times the gross per scre value of erops produced as did the Helmand Valley. It $1 . s$ not expected becanse of solls and other linitations that the average production of Helmand Valley cevalopment areas w11 seach the above 10velso The potential developuent both in acreage and per acxe ylelds is considerable, however. If attention is pald to Inereasing the efflcieney of sarn production and diverm silylng crops, rether than to increasing acreages under wheat, it should bo possible to prodice the wheat raquired on about I/2 of the present acreago This would rev quile an Increase to is 25.0 bushal average. The 1955 Irrigated whost In all Federal reciametion projects of the U. S. avaraged 42 bushols por acre. The balanco of the wheat lasds could bo released for prodralng other crops which would in turn halp to balance rood production agalngt food requirements and gradually provido a more faworakle diet and Ifving standard for the population. 
Harch 7, 1957

Table 23

CROP PRODUCTYON AND CROP VALUES

FEDERAL FECLAMATION PROJJCTS - $1955 \mathrm{~J}$

\begin{tabular}{|c|c|c|c|c|}
\hline cyoors & Unst & $\begin{array}{l}\text { Per Acre } \\
\text { Yields } \\
\text { (1955) }\end{array}$ & $\begin{array}{l}\text { Average Talue } \\
\text { Per that } \\
2955 \\
\text { (Dollars) }\end{array}$ & $\begin{array}{l}\text { Gross Crop } \\
\text { Value } \\
\text { Par Acre } \\
1955 \\
\text { (Dollars) of }\end{array}$ \\
\hline Baxjey & Buse & $36.7=59.7$ & 1.03 & $37,80-60,87$ \\
\hline Whest & $\mathrm{Buz}$ & $34.7=50.2$ & 1.78 & $67.77-89.78$ \\
\hline Alfelf a Hay & Ton & $2.8-5.6$ & 27.98 & $62.54-123.08$ \\
\hline Pasture & ATM & $32=10,6$ & 4823 & $16.50-44.84$ \\
\hline Suger Beets & Ton & $15.5-20.3$ & 9.67 & $149.89-196.30$ \\
\hline Gotton & Bqlo & $2.0-3.6$ & 723.09 & $2 / 2.33=276.94$ \\
\hline Beans, dxer & Cuts. & $1599=17.0$ & 5.24 & $83.32=13.18$ \\
\hline Patatoos lato & Bus & $175.3-327.6$ & 1.010 & $192.83=360.36$ \\
\hline Tomatoes, Fresh & Lug & $134.1-476.7$ & 2.20 & $160.92=11006$ \\
\hline Lottuce & Crate & 196.7 & 257 & 504.67 \\
\hline apoles & Cute. & $791.1-203.5$ & 3.77 & $708.98-754.99$ \\
\hline Peachos & Cuto & $102.8-1.85 .0$ & 3.47 & $356.72=641.95$ \\
\hline Cranes. Table & Cwto & $900-7470$ & 3.50 & $315,00=514050$ \\
\hline Gitrue Fruits & Crto & $204.7=2232$ & 2.53 & $527.89-564.70$ \\
\hline Qgts & $B u_{0}$ & $40.4=60.2$ & -67 & $24.64=36.72$ \\
\hline Alfalfa sod & Cuto & $308-5.2$ & 18.00 & $32.60-91.80$ \\
\hline clover sead & cut. & $20=38$ & 29,00 & $69.60-98,60$ \\
\hline Fer seed & Crts: & $182-203$ & 4.30 & $78.26-87.29$ \\
\hline Onions dey & cute. & $3394=4042$ & 3.50 & $509220-606,30$ \\
\hline 8190 & $\mathrm{Bu}_{2}$ & 62.5 & 2025 & $11062 \%$ \\
\hline Potetoes oarty & $\mathrm{Bu}$ & $622.0-513.0$ & 042 & $173.02-210.33$ \\
\hline Arricots & Cuts & $195.4-285.0$ & 3,50 & $700,00-1000,00$ \\
\hline Cherries & Cwt. & $57.5-80.0$ & 22.50 & $700,00-1000,00$ \\
\hline Brogneorra & Tons & 0.2 & 1000.00 & 2000,00 " \\
\hline Duts, Pocans & cuts. & $8.0=10.8$ & 125.00 & $1000,00-1350,00$ " \\
\hline Corr. III & Bus. & $49.3=640$ & 1060 & $69.02=89.60$ \\
\hline Savsoh & Cute. & 97.0 & 3,00 & $29 \%, 00$ \\
\hline Carrovis & Ton & 19.6 & 22.00 & 235.20 \\
\hline Cantalounge. & Crate & 2132.0 & -2.08 & 261.36 \\
\hline
\end{tabular}

* Prices obtained from other sources.

1/ From: "Grop Report and Related Deta, Federal Reclamation Projects" " U. S. D. I. Bureas of Reclamation, 8/21/56, Washington, D。C.

2/ Man crop ralue per acre for S.W. Arizona and Southerr Gallfornia districts $=\$ 242.20$. Bighest is Coachella Valleg district w1th \$512.20 exop Falue/acro.

1 Lug Tonetoes a $31 \%, 1$ bu。 $=534$

1 Crete lattuse = 75 \# net wio

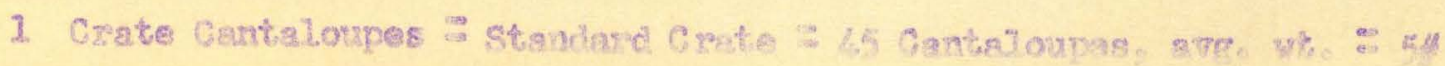




\section{Surfesce Hater Soureos and ourtistigs.}

Wrter sesourcas of the S. W. Afghaxistan Axsa are 1ts several xwers,

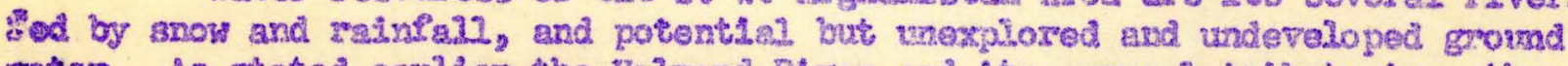

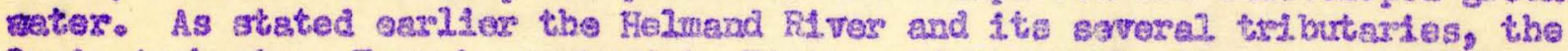

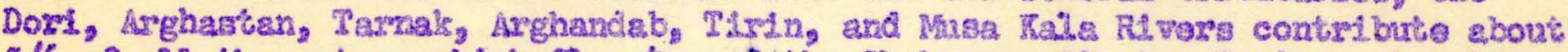

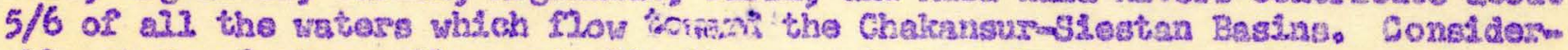

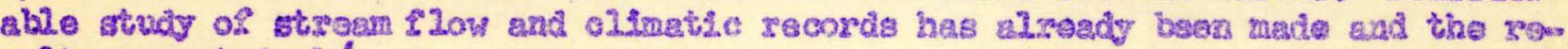
sults seported.

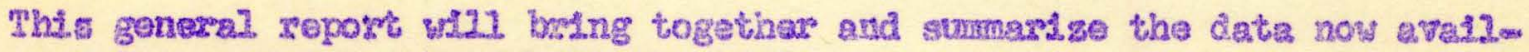
Eble on water rosonzeos throughout the besstn.

2. The Arghandai Sratsmo The Arghandab aysten Lncludes the Dorh to

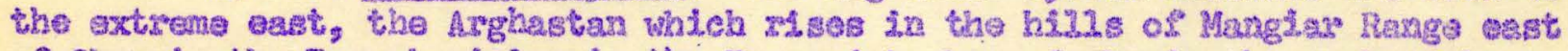
of Charnd, the Taznek rising in the Hezarajat above Jaghort, the Arghandab.

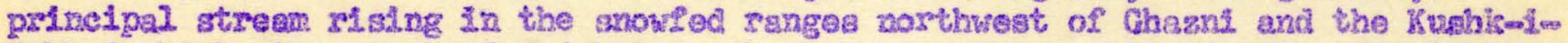
Nakhad thich xises east of Kajainel In the Lower rargeg. Nono of thene Ilou yeas

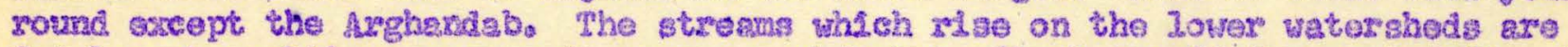

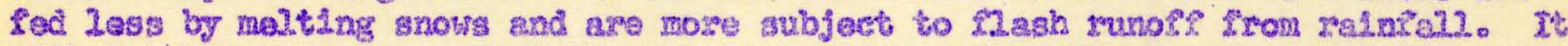
w111 be show, bowsver, that thoy do contribate meanurably to the total Mlos.

The perstod for which gtrean flow has boen measured 1talutes the vater yeare 0ctobar, 1947 to dato. Since the najor Low of the yess has past it is posalbits to present 10 years data, (Table 22), showlng an averege inflow of orar $1,000,000$ acresfeot.

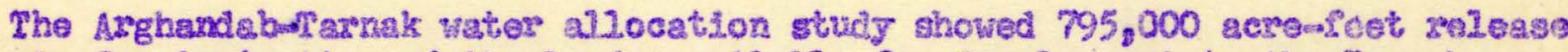
adeguate for Ixrigation of the lands avaliable for developnent in the Texnals Arghandab Area. On this basls 7 of the 10 yos show ample flow and three year: $60-72 \%$ of thet roquired. The Low years occured strigly this allowing easmyorer storage to partaliy offset the water shortage. A coxrolation of raint211 and zunof reace In the above report showed that this relationship could be extenced

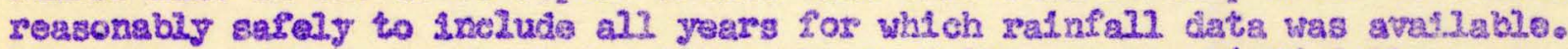

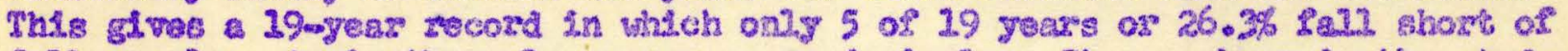

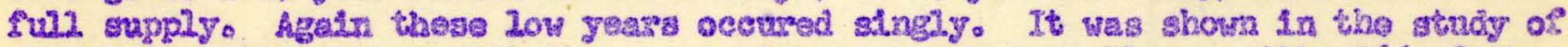
water 217ocetions thet with the regervolr caryover nornaly possibie $96 \%$ of the

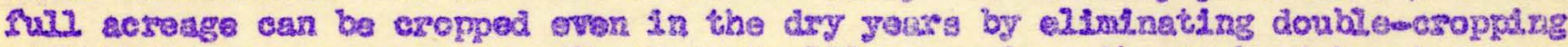
with high use rumer exops. Chaxt Lu D. 332 sturnarize日 the Arghandab water vase

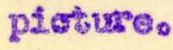

The Arghastan and rarak R1vers pass through considerabie arogs of cultit7stat

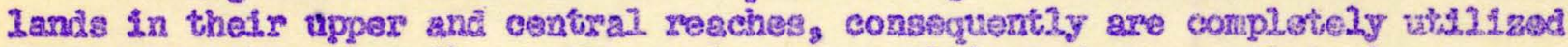

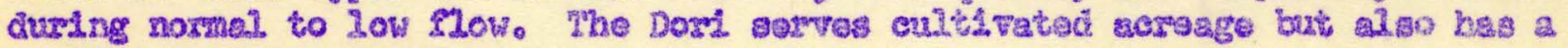
amallex drajnggo axaso

In order to estimate the entributiong of the reveans to waters passtug

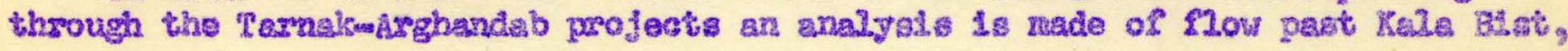

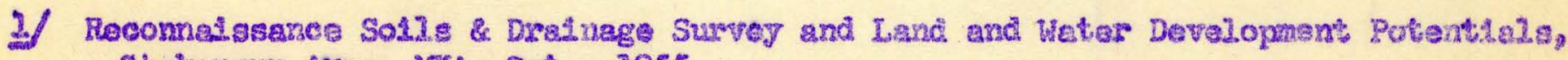
Chaktureus Area, MKA, Octos 1955.

A Study of Arghandebwernals Wetter Allocations, MKA, Julys 1956. 


\begin{tabular}{|c|c|c|c|c|c|c|c|c|c|c|c|c|c|c|c|}
\hline \multirow[b]{2}{*}{ MONTH } & \multicolumn{10}{|c|}{ WATER IEAF } & \multirow{2}{*}{$\begin{array}{l}\text { AVERAGE } \\
\text { LOW YEARS }\end{array}$} & \multirow{2}{*}{\multicolumn{2}{|c|}{$\begin{array}{l}\text { AVERAGE } \\
\text { HIGH YEARS }\end{array}$}} & \multirow{2}{*}{$\begin{array}{l}20 \text { YRS. } \\
\text { AVERAGE } \\
\text { ALI TEARS }\end{array}$} & \multirow{2}{*}{$\begin{array}{l}\text { AVERAGH } \\
\text { INFLOW } \\
\text { CFS }\end{array}$} \\
\hline & $1947-1948$ & $1948-1949$ & $1949-1950$ & 1950-1951] & $1951-1952$ & $1952-1953$ & $1953-1954$ & $1.954 \mathrm{~s}-1.955$ & $1955-1956$ & $1956-1957$ & & & & & \\
\hline por. & 9,540 & 13.500 & $19,74,0$ & 23.780 & 20,980 & 21,030 & 13,250 & 29,227 & 12,530 & 36,740 & 19,930 & 20,0 & 075 & 20,032 & 323 \\
\hline hova & 15,900 & 22,390 & 26,236 & 32,330 & 28,290 & 27,980 & 21,120 & 26.220 & 28,770 & 43,200 & 24.000 & 27.9 & 550 & 26,214 & 442 \\
\hline$M E^{2}$. & $32_{8}, 020$ & 29,510 & 30,740 & 39,870 & 36,740 & 31,630 & 27.440 & 41,830 & 50,700 & 43,190 & 35,160 & 36,8 & 8884 & 36.367 & 589 \\
\hline JAN。 & 24.240 & 30,820 & 95,280 & 38,780 & 39,650 & 31,150 & $44_{2} 850$ & 41,480 & 45,160 & 93,960 & 32,290 & 55.5 & 500 & 48,537 & 783 \\
\hline FEB。 & 24,410 & 34,740 & 70,260 & 47,520 & 68,750 & 93,550 & 289,600 & 33,100 & 77,000 & 119,490 & 50,350 & 85 & 895 & 75,232 & 1,342 \\
\hline MAR. & 145,800 & $293,4,00$ & 135,900 & $14,4,300$ & $16 x, 400$ & 109,300 & 302,000 & 109,800 & 355,500 & $354_{8} 820$ & 121,630 & $249 \sqrt{6}$ & 620 & 221,220 & 3,407 \\
\hline APR。 & 185,900 & 271.100 & 326,800 & 262,200 & $24,2,1.00$ & 79,400 & 339,000 & 63,490 & 536,000 & 697,000 & 209,600 & 382 & 049 & 300,300 & 5,006 \\
\hline MAY & 76,250 & $92,64,0$ & 285,900 & $302_{3} 100$ & 111,370 & 46,360 & 228,000 & 61,560 & 189,100 & $(201,000)^{2}$ & 61.390 & 202. & 445 & 259,430 & 2.572 \\
\hline JUN. & 26,420 & 32,730 & $74_{8} 830$ & 80,290 & 37,910 & 28,860 & 74,000 & 25,100 & 66,300 & $(60,900)$ & 26,790 & 60,9 & 995 & 50,735 & 84,6 \\
\hline jus. & $14_{8} 680$ & 17,570 & 35,420 & 34,010 & 27,930 & $10_{8} 050$ & 45,900 & 9,460 & 233,000 & $(35,000)$ & 13,400 & 61,2 & 260 & 46,300 & 747 \\
\hline AUG. & 9,990 & 21,990 & 25,120 & 20,920 & 22,950 & 7,060 & 22,900 & 7,500 & 64,600 & $(25,000)$ & 8,180 & 29,8 & .070 & 22,800 & 368 \\
\hline pEP. & 5,860 & 10,780 & 18,860 & 18,800 & $18,34,0$ & $7,4,60$ & 20,017 & 5,620 & 30,200 & $(19,500)$ & 6,310 & $19:$ & .500 & 15,545 & 259 \\
\hline TOTALS & $\begin{array}{c}571,010 \\
(\mathrm{I})\end{array}$ & $\begin{array}{c}870,970 \\
(\mathrm{H})\end{array}$ & $\begin{array}{c}1,14,4,976 \\
\text { (H) }\end{array}$ & $\mid \begin{array}{c}1,044_{9}, 900 \\
(\mathrm{H})\end{array}$ & $\begin{array}{c}816,410 \\
\text { (H) }\end{array}$ & $\begin{array}{c}493,830 \\
\text { (1.) }\end{array}$ & $\begin{array}{c}1,328,077 \\
\text { (H) }\end{array}$ & $\begin{array}{c}456,287 \\
\text { (I) }\end{array}$ & $\begin{array}{c}1,673,860 \\
(\mathrm{H})\end{array}$ & $\begin{array}{c}1,729,800 \\
\text { (H) }\end{array}$ & $507 ; 030$ & 1,229, & 883 & $1,013,012$ & 2,388 \\
\hline
\end{tabular}

* Inflow quantities for Arghandab Dam $=I_{0} C_{3} A_{0}$ Records。

$\%$ May-Sept., 1957, extrapolated.

Seasonal Distribution - Low Years: Dec-May $\approx 410,420$ or $81 \%$ and June-Nov。 $=96,610$ or $19 \%$; High a nd Normal Years: Dec-May $=1$, 011, 390

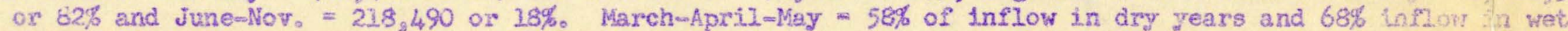

cr rocial years. 


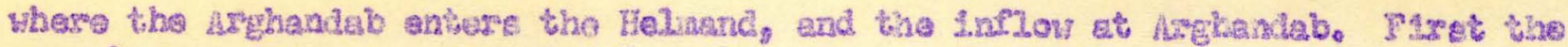

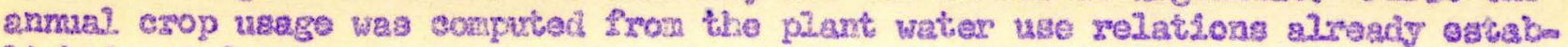

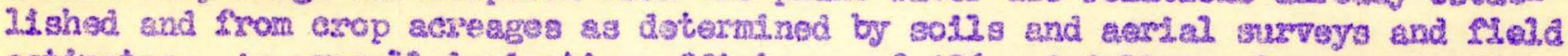

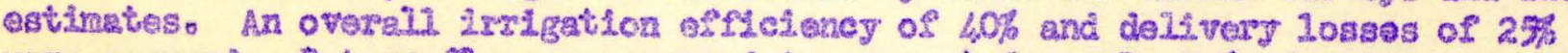
wero assuned. Roturn flow was assuned to account for only 5 \& of vater use. The

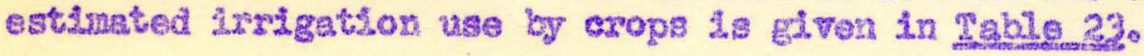

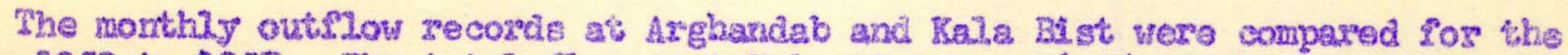

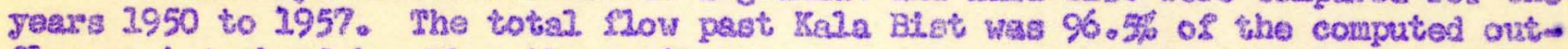

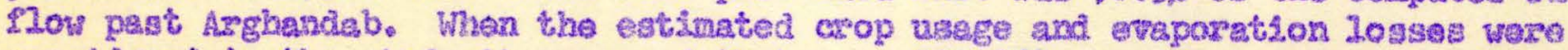

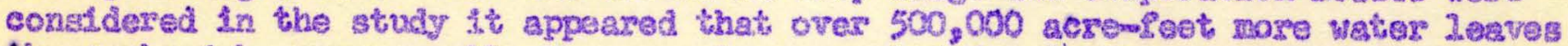
the Arghandab arsa annuelly than can be accounted for by the Arghanciab Mow alone.

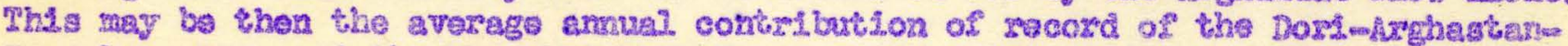

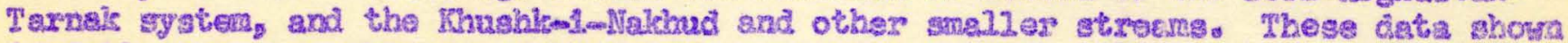
Ir. Table 24, show that the method of conputation acconnts Por 211 hat $5.6 \%$ of the

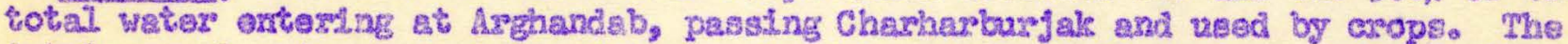

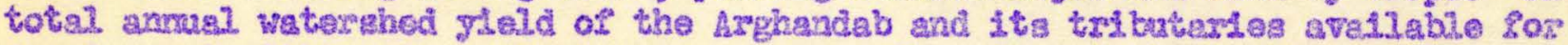
devolopant uithin the project aroas appeas therefore to be $1 \mathrm{n}$ the nelghborbood of $1,300,000$ acrereset.

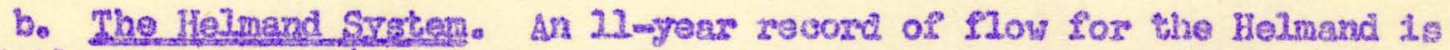
given in Tabio 25. The1946-1947 jocote 19 not m memurement at Kajakn. The last three morths of 1957 wather year are Interpolated. From thege data It can be

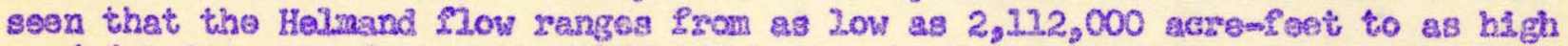
as $8,840,000$ rerenfeet whth $5,100,000$ beIng about the avergge. In the Chakensur Study an attempt was made to ovaluate the 1Low ovor \& Longar perlod of tine. Tho

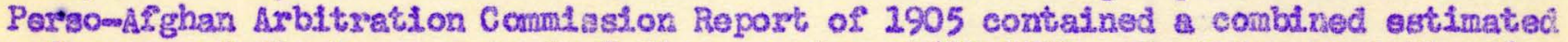

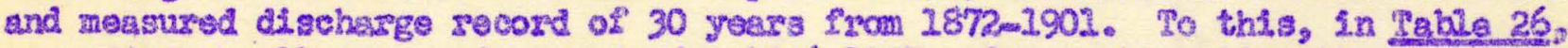
whs added the 11 Jears of recols for $1946-1957$, aftor aubirecting the 7ory vnusuel

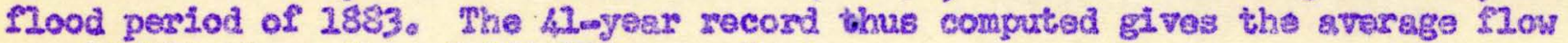
as silighty less than $5,000,000$ scrow feot.

In 1952, Stanley and Charler of MEA made a boat toz:p down the Fielnand from

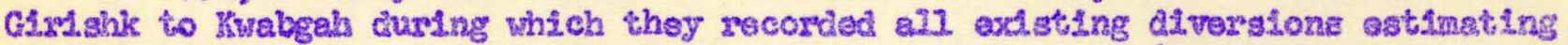

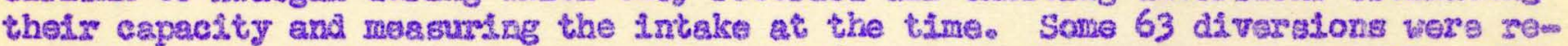
portod. 14 of which were rot operating and 8 were in disrepair and unusable. The comblned capectity at the Intakes was astimated at 3.748 eusas. A total of 31

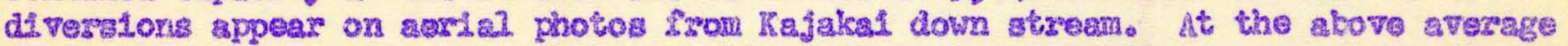
this anounts to 4,473 cuseca total conhined divarion capactisy or enough to di-

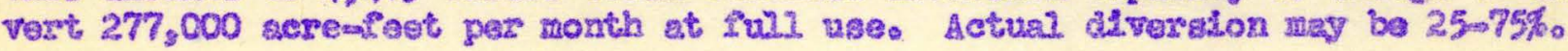

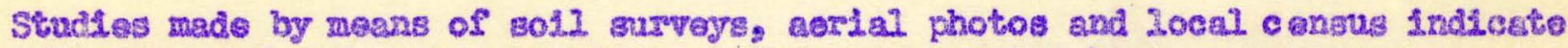
that per acromonth ditresion requirement by crops and total crop acreages aro

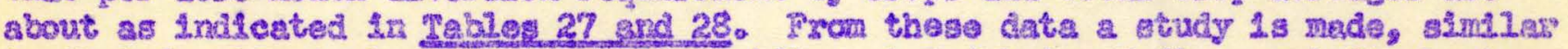

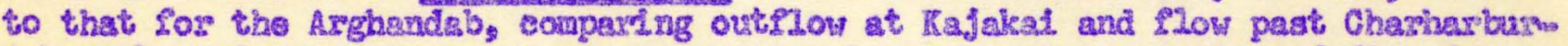
jak with estinsted crop rBe and ovaporation losees. The sumation of flov Irosa Holnand ard othor sourees then conputod monthiy and compared wh th astimatad erop and evaporation 20 sses secounted for 211 but $0.9 \%$ of the total water. Table 29 , showe thet about $2,350,000$ acromfeet of watar enters the Halnand in addition to that measured at Rajakai. It has alresdy been shown $1 \mathrm{r}$ T2bio 24 thet approxt-

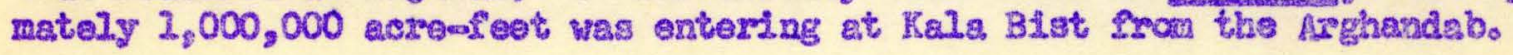


Estingted Water Uso by Crops, 1950-1957*

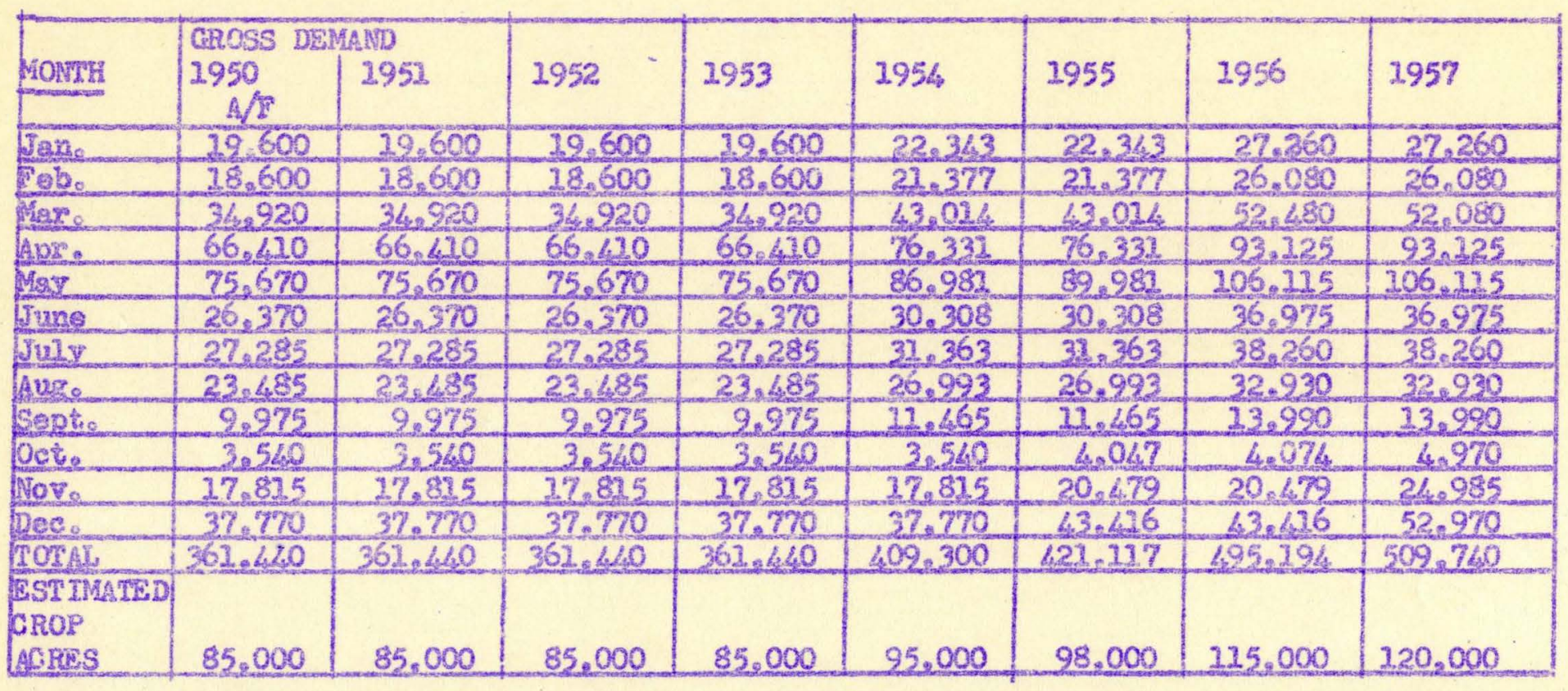

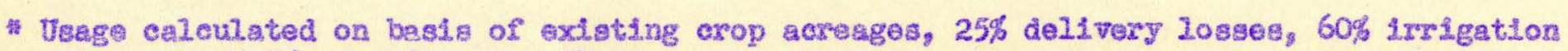
losess and $5 \%$ use of sotura 1 LW 
A STUDY OF WATER FLOW RECORDS AT ARGHANDAB AND YALA BIST WIXH REFERENCE TO CROP USE AND SOURCES OF WATLR 3

\begin{tabular}{|c|c|c|c|c|c|c|c|}
\hline Koar & $\frac{\text { At Arghendab }}{\text { Inflow }}$ & $\frac{\text { Reserzyolx }}{\text { outriou }}$ & $\begin{array}{l}\text { Plow Past } \\
\text { Kaia } 81 \text { ts }\end{array}$ & $\begin{array}{l}\text { Annual Excess } \\
\text { of Kela Blst } \\
\text { over } \\
\text { Arghandab }\end{array}$ & $\begin{array}{l}\text { Est1mated } \\
\text { Crop } \\
\text { Ussge }\end{array}$ & $\begin{array}{l}\text { Difference of } \\
\text { Arghandab } \\
\text { Release and } \\
\text { Crop Urage }\end{array}$ & $\begin{array}{l}\text { Calco } \\
\text { Flow from } \\
\text { other } \\
\text { Sources }\end{array}$ \\
\hline 1950 & $1.158,105$ & No Becore & 1558,463 & 622.521 & 361.440 & 796.665 & 820,233 \\
\hline 1922 & 12.054 .721 & No Record. & 555.350 & 1,485 & 361,440 & 692,281 & 51.775 \\
\hline 0953 & 493830 & 590,400 & 205,320 & 82,250 & 361,440 & 228,960 & 119,600 \\
\hline 2954 & $1,328.077$ & 1.237 .830 & $3,396,310$ & 406,290 & 409,300 & 728.520 & 866.873 \\
\hline 1255 & 466,287 & 591,346 & 148,697 & -2 & 421.117 & 270.229 & 90.729 \\
\hline 2956. & $1,673.360$ & 1.488 .650 & $1,731,510$ & 608,720 & 495.194 & 993.456 & 802.061 \\
\hline $\begin{array}{l}7 \mathrm{MO} \circ \\
1957\end{array}$ & 1.728 .900 & $2,782,670$ & $1.960,000 \%$ & $600,000 \%$ & 509,760 & $1.272 .930 \%$ & $800,000 \% 2 /$ \\
\hline Totals & 7.903 .280 & 7.803 .712 & 7.555 .614 & 2.121 .166 & 291267 & 4.884 .047 & 3.547 .771 \\
\hline AVSo & $12.129,040$ & 2.114 .816 & $3,079.516$ & 303,024 & 417.097 & 697.720 & 505,967 \\
\hline
\end{tabular}

Estimated by comparison with slmilar years.

2/ The flrst three columa of dats are from ICAMMA records. The crop use estlmate 1s based on crop acreage measur from solls and aerial surveys。 Consumptive use tables for the orops grown axe those computed in the report on Arghandab-Tarmair Water AllocatLons, July 1956.

$2 /$ Approxlmately 92,600 Acros of water 1 s not accounted for after subtracting 31,500 for reservolr evaporation 10 s This amounts to about $5.6 \%$ of the total. 


\section{(Kajakal to Rudbar)}

(Total Divarsion in Acrefeet/Acre by Crops)

\begin{tabular}{|c|c|c|c|c|c|}
\hline & $\begin{array}{l}\text { Orchards } 1 / 3 \\
\text { f Vineraris } 2 / 3\end{array}$ & $\begin{array}{l}\text { Whost and } \\
\text { Othor Grolns }\end{array}$ & $\begin{array}{l}\text { Alfelfa } \\
\text { Pasture }\end{array}$ & $\begin{array}{l}\text { Evapotranspir } \\
\text { ation losses fron } \\
\text { brush grasg \& treas }\end{array}$ & $\begin{array}{l}\text { Summex } \\
\text { Crops }\end{array}$ \\
\hline $\begin{array}{l}\text { January } \\
\text { February } \\
\text { March } \\
\text { April } \\
\text { May } \\
\text { June } \\
\text { July } \\
\text { August } \\
\text { September } \\
\text { October } \\
\text { November } \\
\text { December } \\
\end{array}$ & $\begin{array}{l}0.055 \\
0.158 \\
0.313 \\
0.313 \\
0.900 \\
1.087 \\
1.225 \\
1.025 \\
0.663 \\
0.313 \\
0.250 \\
0.187 \\
\end{array}$ & $\begin{array}{l}0.537 \\
1.000 \\
1.350 \\
0.413 \\
0.637 \\
0.137 \\
0 \\
0\end{array}$ & $\begin{array}{l}0.137 \\
0.212 \\
0.625 \\
1.238 \\
1.600 \\
1.938 \\
2.088 \\
0.838 \\
1.325 \\
1.125 \\
0.688 \\
0.350 \\
\end{array}$ & $\begin{array}{l}0.042 \\
0.062 \\
0.189 \\
0.375 \\
0.483 \\
0.583 \\
0.625 \\
0.250 \\
0.400 \\
0.337 \\
0.208 \\
0.104\end{array}$ & $\begin{array}{l}-\infty \\
0.575 \\
0.625 \\
1.375 \\
1.250 \\
1.013 \\
0.838 \\
-\end{array}$ \\
\hline Lears & Acres in Ereh I & rne of Grop & & & \\
\hline $\begin{array}{l}1948-1950 \\
1951 \\
1952 \\
1953 \\
1954 \\
1955 \\
1956 \\
1957 \\
\end{array}$ & $\begin{array}{c}20,000 \\
" ~ \\
" 1 \\
22,500 \\
25,000 \\
n \\
n \\
n\end{array}$ & $\begin{array}{l}50,000 \\
52,000 \\
56,000 \\
75,000 \\
80,000 \\
100,000 \\
105,000 \\
\end{array}$ & $\begin{array}{r}550 \\
700 \\
2,050 \\
7,500 \\
9,000 \\
9,500 \\
10,000 \\
\end{array}$ & $\begin{array}{c}100,000 \\
n \\
n \\
n \\
n \\
n \\
n\end{array}$ & $\begin{array}{c}10_{2}, 000 \\
n \\
11,300 \\
29,000 \\
30_{3}, 000 \\
n \\
n \\
n\end{array}$ \\
\hline Ue & $33^{n}$ & $18.5^{n}$ & $55^{m}$ & $44^{\circ}$ & $25^{n}$ \\
\hline
\end{tabular}


1948-1957 - ESPTMATED WATER USAGE, RAJAKAX TO RUDBAR, IN ACRE FFEET

\begin{tabular}{|c|c|c|c|c|c|c|c|}
\hline MONTI & $\begin{array}{c}\text { GROSS DKMAMD } \\
3948-1.950 \\
\mathrm{~A} / \mathrm{F}\end{array}$ & 2951 & 2952 & 1953 & 2954 & 2955 & $3956-1957$ \\
\hline Januezy & 5825.00 & 5850.00 & 6031.25 & 6937.50 & 7300.00 & 7368.75 & 7437.50 \\
\hline Cebruery & 10177.50 & 20150.00 & 30437.50 & 12000.00 & 12725.00 & 12831.25 & 32937.50 \\
\hline Masch & 53898.25 & 55067.50 & 58062.25 & 72461025 & 76874.50 & 87930.00 & 90930.00 \\
\hline$\Delta \mathrm{ng} 1$ & $97 / 31.25$ & 99672.50 & 205287.50 & 231832.50 & 139450.00 & 160068.75 & 165687.50 \\
\hline Isy & $14,325.00$ & 247262.50 & 255575.00 & 202375.00 & 24350.00 & 262750.00 & 269700.00 \\
\hline รัunge & 92065.00 & 92375.00 & 95787.50 & 120125.00 & 126375000 & 127343075 & 128312.50 \\
\hline TuTy & 106900.00 & 107212.50 & 211812050 & 150593.75 & 358162.50 & 159206.25 & 160250.00 \\
\hline Aucust & 88812.50 & 86937.50 & 91693.75 & 220043.75 & 126012.50 & $124,31 \cdot 325$ & 126850.00 \\
\hline Soptember. & 67300.00 & 67500.00 & 70613.50 & 97406.25 & 102062.50 & 202725.00 & 103387.50 \\
\hline Qctobor & 72325.00 & 36862.50 & 77575.00 & 207213.75 & 212512.50 & 221325.00 & 123950.00 \\
\hline Hovonbor & 59750,00 & 61725.00 & 66612.50 & 81093.75 & 85237,50 & 99033.25 & 202562.50 \\
\hline Decomber: & 22062.50 & 22400.00 & 23428.75 & $28406_{2} 25$ & 32087.50 & 33012.50 & 33875.00 \\
\hline $20 \Omega$ & 823832.50 & 833805.00 & 873905.00 & 1334298.75 & 2394842.50 & 2282423.75 & 308880.0 \\
\hline $\begin{array}{l}\text { DSP.WMATD } \\
\text { GROD ACBS }\end{array}$ & 580550 & $82 \% 00$ & 89350 & 3,36000 & 142000 & 164500 & 270000 \\
\hline
\end{tabular}

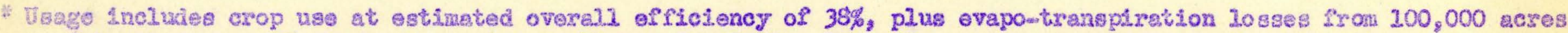
of brush trees and grass along rlver valley. See Tablo 27 for cropsy crop acres and consumptive use. 
A STUDY OF HEIMAND RIVER FLOW AT KAJAKAI AND CHARHARBURJAY WITH HEFEREACE TO CROP USE AND SOURCES OF UATER I

\begin{tabular}{|c|c|c|c|c|c|c|c|c|}
\hline \multirow[b]{2}{*}{ Ygar } & \multicolumn{2}{|c|}{ At Kajleks Relsexyolx } & \multirow{2}{*}{$\begin{array}{l}\text { End }=0 \text { of who } \\
\text { Stor. Acres feet }\end{array}$} & \multirow{2}{*}{$\begin{array}{l}\text { Low Pest } \\
\text { Charharbur jal } \\
\text { Acre-feet }\end{array}$} & \multirow{2}{*}{$\begin{array}{l}\text { Sum of MO } \\
\text { Excess Flow at } \\
\text { Chaxhaxbur jak }\end{array}$} & \multirow{2}{*}{$\begin{array}{l}\text { Crop \& } \\
\text { Other Voge } \\
\text { Uses }\end{array}$} & \multirow{2}{*}{$\begin{array}{l}\text { DIffo of Kajas } \\
\text { kal Pelease \& } \\
\text { ost. Crop Vas }\end{array}$} & \multirow{2}{*}{$\begin{array}{l}\text { Calo Flow } \\
\text { of Water from } \\
\text { ther Sources }\end{array}$} \\
\hline & $\begin{array}{l}\text { Inflow } \\
\text { Acroefoet }\end{array}$ & $\begin{array}{l}\text { Outhlow } \\
\text { Aone- Pest }\end{array}$ & & & & & & \\
\hline 1249 & & No Record & No Record & $5,422,879$ & 689.109 & 820,810 & $4,392,598$ & $1,107.322$ \\
\hline 1950 & & No & 1 & $6,072,872$ & $1.569,704$ & 820,810 & $4.256,462$ & 2.055869 \\
\hline 1951 & & No ReC & No & 5.645 .380 & 112.500 & 828,103 & 5.357 .992 & 498,933 \\
\hline 1952 & $4,816,400$ & No Record & No $R$ & $4,186,000$ & $20,1,00$ & 825,682 & $3,990,709$ & 429,627 \\
\hline 1953 & 46086,900 & $3,393,000$ & & 5546980 & 205,500 & 13.080 .207 & 2.312 .785 & 433,218 \\
\hline $195 \mathrm{~s}$ & $5,821,190$ & 5 & & 6 & $2,702,200$ & 1.179 .252 & 3.984 .692 & $28082 \%$ \\
\hline 2955 & & & 0 & & & 1.253 .588 & $2.520,575$ & 889 \\
\hline 1956 & & 20 & & & 600 & 3,298, & 4.243 .237 & \\
\hline 1957 & & $5.904 .650 \%$ & & 6.555 .000 & 1.445.000\% & 1.305 .877 & $4.598 .773 \%$ & $1.955 .000 * 2$ \\
\hline 0482 & 68.087 .730 & 45.770 .962 & $3,647.256$ & $66,677.051$ & 6.935 .613 & 9.433 .886 & 36.356 .822 & \\
\hline trgo & $5.343,087$ & $5,085,6620$ & $911.81 /$ & $5,16 / 4339$ & 770.626 & 17.045 .987 .3 & $4.037,313$ & \\
\hline
\end{tabular}

Eistimated by comparison with sim11 ax years.

1 The first four column are taken from ICAMKA records. Tho srop use estimate 1s based on crop acreage measurement from surveys and aerial photos and avarage consumptive uae tables for the comnon erops. (S00 Table 27 .

2) Approximately gr, 000 acro-feot of the water, after subtracting an estimsted 150,000 for ovaporation 10 sses, is not accounted for by the assumptions made. This may be additional irrigation wastage and stream bed lossse. It arounts to c. $9 \%$ of the total. 


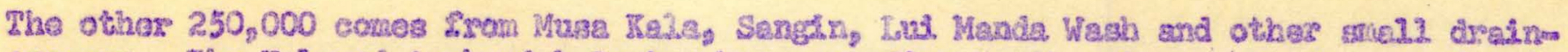

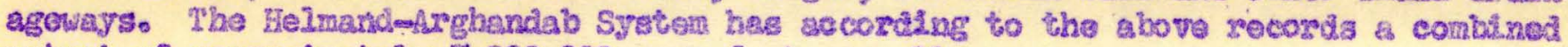
outpur of approzinately 7,000,000 aarem feet amanaliy.

The relationsh? of 1 lows messured at the fvur gavglng gtations studied above

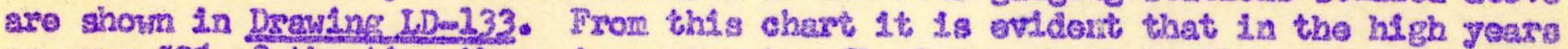
or over $50 \%$ of the time there 2 more weter Llowing past the ortilets of these zivers than pasges the damattess. A grephie story of the water use history of the Halmendm

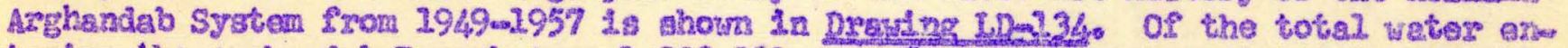

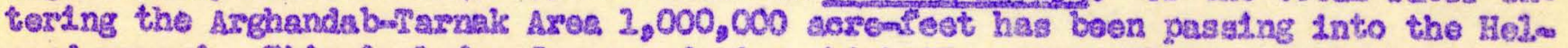
wand unaset. Thin Includes 5 yoars curing which the Arghendrb Resarvols was in oparation. of the combined waters of ell gureams anounting to $7,000,000$ asremseot,

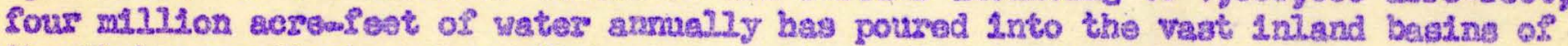

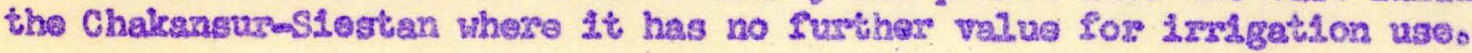

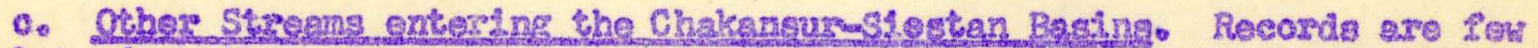
and 1neoxplete for other stroens. Duxing high wator the roads aro Impassable. Masy

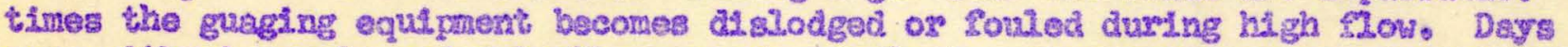

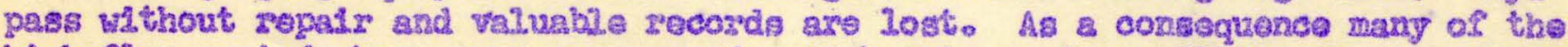

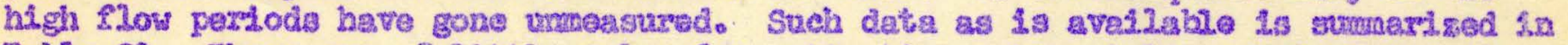

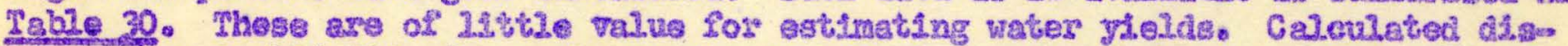

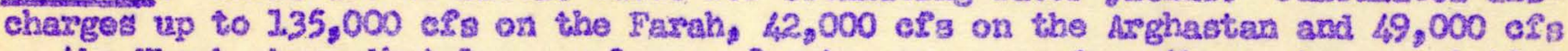

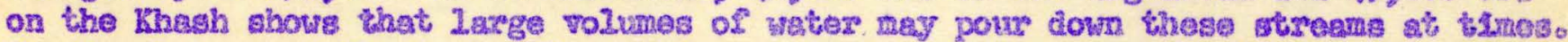

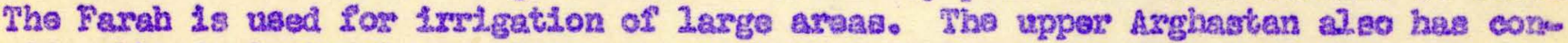
sidarabio Irrigated lard Thore aro scattered viliages and farm lend along the Khash batwesn DLIaram and Chairanarak.

A summery is preasted in Teble 31 of all stream waters in the whterghsis of the Chakansur-S1entan Bssins. These date are party fron strosm geughng reconds,

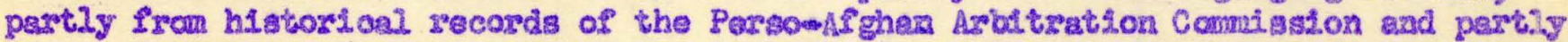
from correlation of watoxhed axses and alevations vith water ylalds per valt axeg. The total indsated 1s on the ordar of $12,000,000$ acre-feets It 1. recogrized that

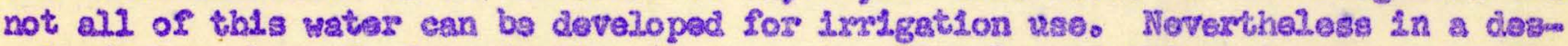

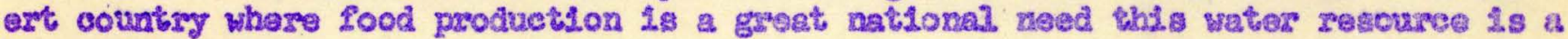
tremendous \&ะset.

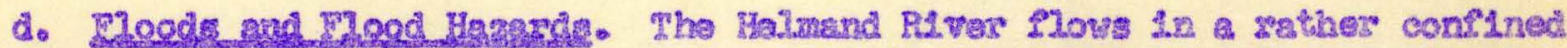

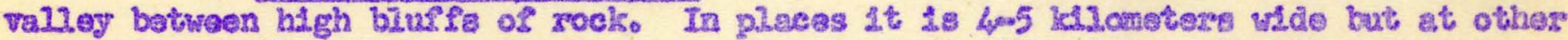

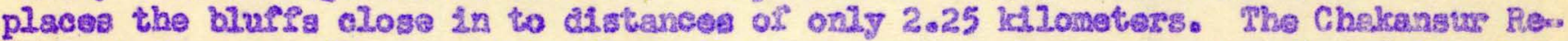

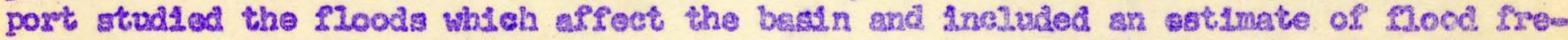

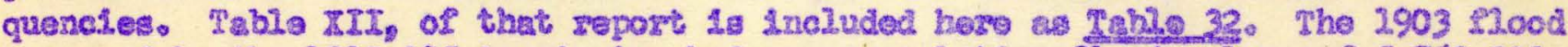
reasured by the $1903-105$ Corantsaton hed an aceurulative 1100d volume of $5,780,000$ acrefeot. The 11ood srequensy graphs show 2loods of the ragnttude of the 1903

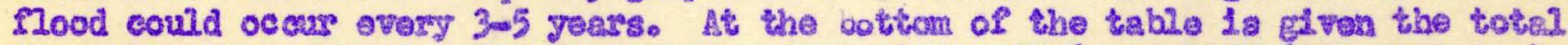
Ilow past Chaxharbuxjak for Lour jeax:, $1950,195 \% 1956$ and 1957 (Intarpolatod). All of these years excosded the 1903 glood in total wolune exherting the bagitse

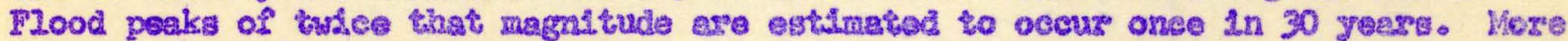

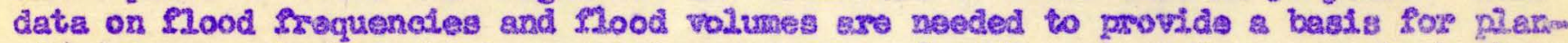

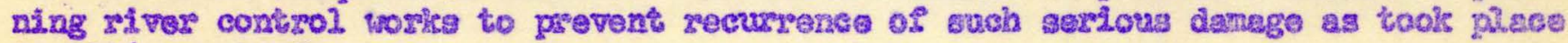
In 1956 and 1957.

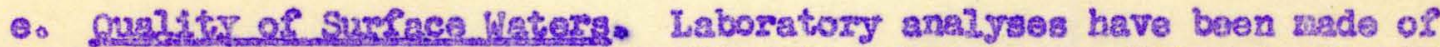

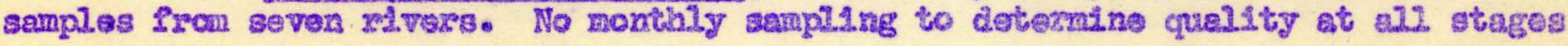




\section{RELATION OF STREAM FLOW AT 4 MA JOR GAUGING STATIONS ON THE}

\section{HELMAND-ARGHANDAB RIVERS}

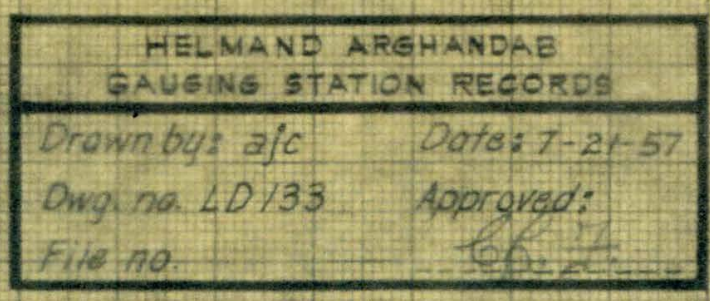

\section{HELNAND RVER}

\section{ARGHANDAB RIVER}

KAJAKAI $0=-0 \quad-0$

CHARHARBURJAK $X-+-+-X$
DAM AT ARGHANDAB ABOVE

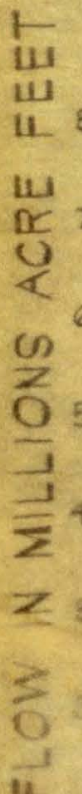
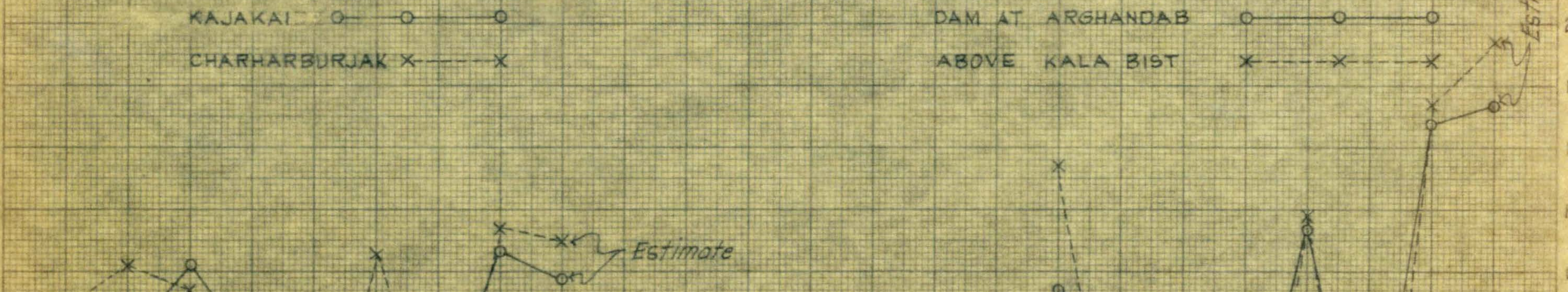

4 w 


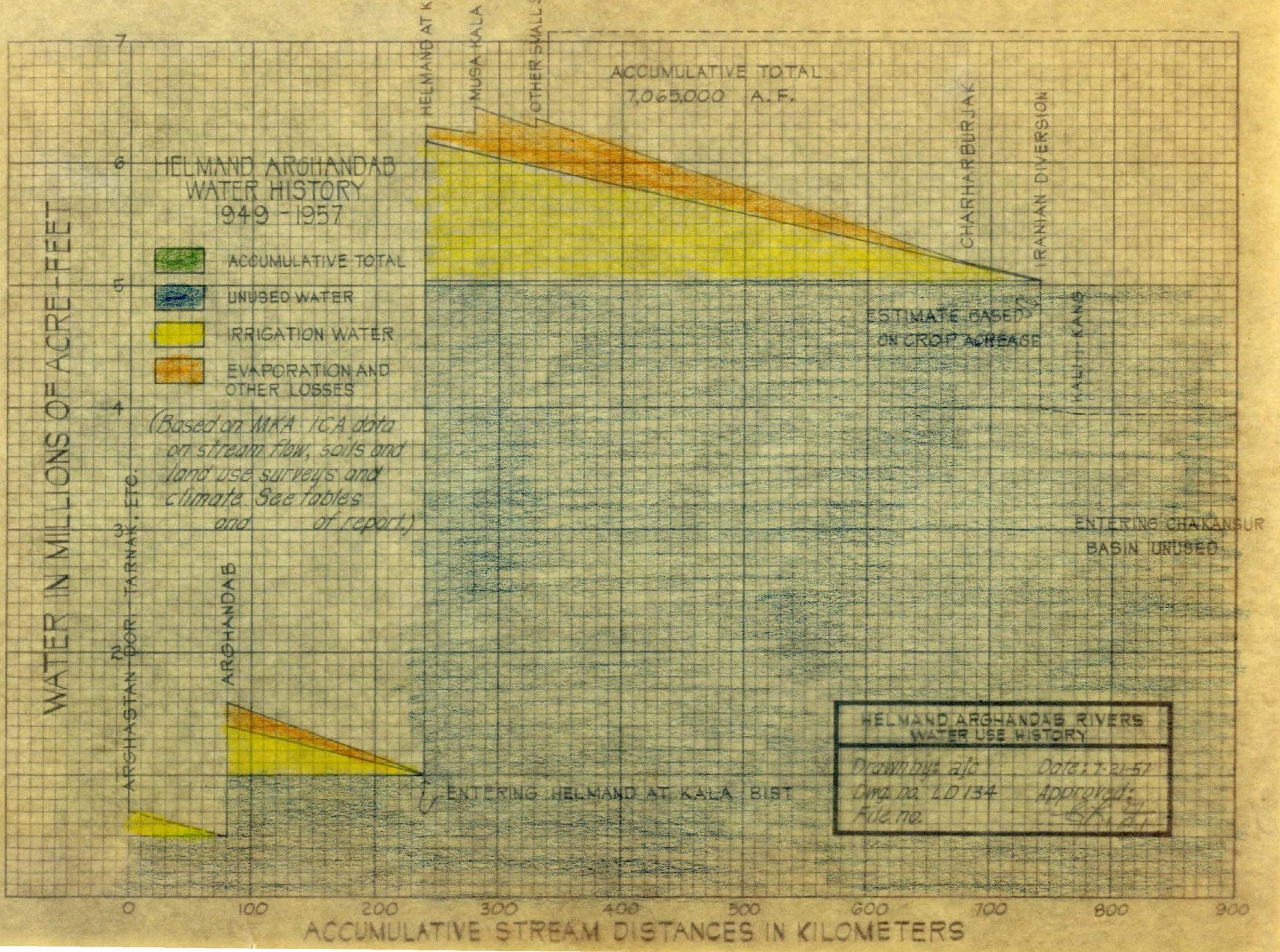


Table 30

SUMARY OF STREAM FLOW DATA FOR OTHER STREAMS $y$

$7 / 22 / 57$

\begin{tabular}{|c|c|c|c|c|c|}
\hline$\frac{Y \text { Toar }}{5010}$ & $\begin{array}{l}\text { Arghastan } \\
6620 \text { Sq. Mi. } \\
\text { Acre- Feet }\end{array}$ & $\begin{array}{l}\text { Tarah } \\
10,400 \mathrm{Sq} . \mathrm{Mi} . \\
\text { Acrea Peot }\end{array}$ & $\begin{array}{l}\text { Chazni } \\
495 \mathrm{Sq} \text {. Mi. } \\
\text { Acre-Feet }\end{array}$ & $\begin{array}{l}\text { Khash } \\
2030 \text { Sq. MMI. } \\
\text { Acreofeat }\end{array}$ & 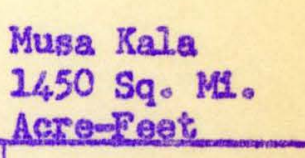 \\
\hline 1949 & $=$ & -1 & & 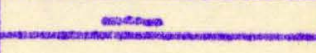 & \\
\hline 1950 & $=$ & $=$ & $\begin{array}{r}(2,42) \\
49,460 \\
\end{array}$ & $=$ & $=$ \\
\hline 1951 & $=$ & $=$ & $\begin{array}{r}(454) \\
65.100\end{array}$ & - & $=$ \\
\hline 1952 & - & $=$ & (317) & $=$ & $=$ \\
\hline 1953 & $\left(\begin{array}{l}11 \\
74,700)\end{array}\right.$ & $\begin{array}{c}(127,000) \\
794,392 \\
\end{array}$ & $=$ & $\begin{array}{l}(26,700) \\
116,600 \\
\end{array}$ & $\begin{array}{l}(6,620) \\
98,870\end{array}$ \\
\hline 1954 & (anses & $(68,200)$ & $=$ & $\begin{array}{r}i 9,380) \\
395,430\end{array}$ & $\begin{array}{l}(7,600) \\
181.51)\end{array}$ \\
\hline 1955 & $\begin{array}{l}(2,780) \\
14.662 \\
\end{array}$ & $=$ & $=$ & $\begin{array}{l}(49,000) \\
330,716 \\
\end{array}$ & $\begin{array}{l}(38,000) \\
100,847 \\
\end{array}$ \\
\hline$\frac{1956}{1957}$ & 410,004 & $=$ & $=$ & $=$ & \\
\hline$\frac{1977}{10 \operatorname{tal} 1.9}$ & 494.458 & $=$ & 114.600 & 872.726 & $\frac{(71.0001}{381.228}$ \\
\hline $\begin{array}{l}\text { cf's Max。 } \\
\text { Discharge }\end{array}$ & $42.100-2 / 13 / 54$ & $135.000-3 / 18 / 55$ & $4.54-5 / 6 / 52$ & $420000-3 / 15 / 55$ & $71.000=3 / 17 / 57$ \\
\hline $\begin{array}{l}\text { Average or } \\
\text { Abore }\end{array}$ & 167,000 & $=$ & 57.300 & 290.908 & 127.076 \\
\hline $\begin{array}{l}\text { Runori } \\
\text { Inches: }\end{array}$ & $.0473^{m}$ & $1043^{n}$ & $3.17 \mathrm{~m}$ & $2.62^{\prime \prime}$ & \\
\hline
\end{tabular}

1/ These are mostly from ICA records. Dlfficulties of travel and maintenance of equipm ment have been such that there are very fow complete records. High Ilows are often not measured because of equipment demage and inecessibility for repalr.

2/ Maximum discharge in cubic feet per second. 


\begin{tabular}{|c|c|c|c|c|c|c|c|c|}
\hline SATTERSYDD & $\begin{array}{l}\text { AREA } \\
\text { SO. MTIES }\end{array}$ & $\begin{array}{l}\text { EST: } \\
\text { ANNUAL } \\
\text { RUNSOFF } \\
(\text { (ano) }\end{array}$ & $\begin{array}{l}\text { NORWAL } \\
\text { RUYYOFF } \\
\text { PERTOD }\end{array}$ & $\begin{array}{l}\text { EST? } \\
\text { REAK } \\
\text { RUNOFF } \\
\text { CUSBSS }\end{array}$ & $\begin{array}{l}\text { AWWAL } \\
\text { YTELD } \\
\text { ACEE/WEET }\end{array}$ & 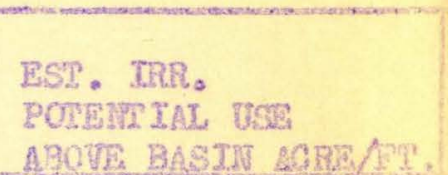 & 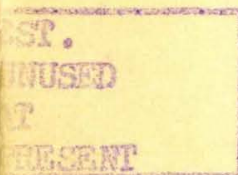 & 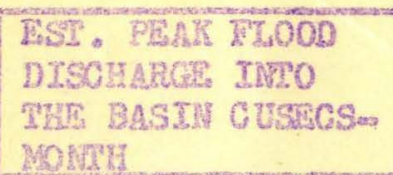 \\
\hline Helroand (total) & 207,189 & $\frac{1}{3.23}$ & Annual & $\begin{array}{l}600,000 \\
200,000\end{array}$ & $7,302,000$ & 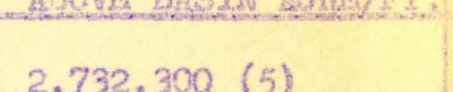 & & 225,000 \\
\hline Arghandab Boloy Dam & $\frac{3.649}{3.321}$ & $\frac{1.00}{1.50}$ & $\frac{\text { JaneMar }}{\text { Febryay }}$ & $=$ & $\frac{87,000}{260.000}$ & $\frac{A 73}{A 33}$ & & $=$ \\
\hline Prarnak & $\frac{3.321}{5.780(2)}$ & $\frac{1.50}{1.00}$ & $\begin{array}{l}\text { Fob }=\text { May } \\
\text { Feb-May }\end{array}$ & 42,000 & $\frac{260,000}{300,000}$ & $\frac{A 21}{A 71}$ & $00 \%$ & $=$ \\
\hline $\begin{array}{l}\text { Arghastan } \\
\text { Dort }\end{array}$ & $\frac{5,780(2)}{3.285}$ & $\frac{1.00}{1.00}$ & rebollay & $-\infty$ & $\frac{300,000}{175,000}$ & Unimoun & - & - \\
\hline Chah Baig1 & 3.180 & 0.15 & Fob-Aor 11 & $=$ & 10,000 & None. & 11 & $=$ \\
\hline Rud-i-Khas & 682 & 0.15 & Fob-Aprit & $=$ & 5,000 & Nono & 11. & 100 \\
\hline Gauspes & 2.607 & 0.50 & Fob-Apre1] & 3.500 & 60,000 & $-50 \%$ & 05 & 2,000 \\
\hline Khash & 5.183 & 1.73 (4) & Jarn-June & 19,000 & 480,000 & A 71 & 08 & $22,500(4)$ \\
\hline Farah & 10.624 & $3.43(4)$ & Jan-June & 135,000 & 950,000 & $60 \%$ & $0 \%$ & 700,000 (4) \\
\hline Harud & 13,072 & $1.02(4)$ & Fob-June & 45,000 & 710.000 & Unknown & $0 \%$ & $45.000(4)$ \\
\hline Musa Kala & 2.580 & 2.00 & Jan-June & 77,000 & 275,000 & $-85 \%$ & 03 & $-\infty$ \\
\hline Sanguin & 3,000 & 1.00 & Fob-l/ay & - & 160,000 & $20 \%$ & $55^{5}$ & $\ldots$ \\
\hline
\end{tabular}

NOTES: (1) HeImand and Arghandab sbove dams based on watershed above dam and 20 yrs. Inflow records.

(2) Area of 6,437 sqo Intles - above Lake Ab-1-Istada is excludedo

3) An estimated 4,056 sq. miles of Registan and Dashtel-Margo do not contribute to ruanfo

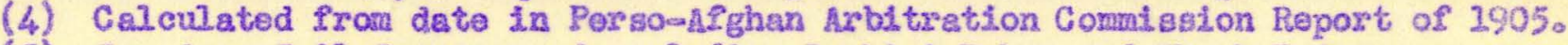

(5) Based on Soll Survoys end excluding Dasht-i-Bakws and Khash Rud Areas. 


\begin{tabular}{|c|c|c|c|c|c|c|c|}
\hline DATES & $\begin{array}{l}\text { Ace. } \\
\text { Vol. } \\
\text { Helmand }\end{array}$ & $\begin{array}{l}\text { Ace. } \\
\text { Vol. } \\
\text { Other } \\
\text { Streams }\end{array}$ & $\begin{array}{l}\text { Total } \\
\text { Acc. } \\
\text { Vol. } \\
1 \text { \& } 2 \\
\end{array}$ & $\begin{array}{l}\text { Evapo } \\
\text { Rates } \\
\text { Eeet/Dar }\end{array}$ & $\begin{array}{l}\text { Acc. } \\
\text { Evap. } \\
\text { and } \\
\text { Perc. } \\
\text { Losseg. }\end{array}$ & $\begin{array}{l}\text { Bst. Acc. } \\
\text { Net Water } \\
\text { Use (Ire.) }\end{array}$ & $\begin{array}{l}\text { Balance } \\
\text { or } \\
\text { Water } \\
\text { Volume } \\
\text { in } \\
\text { Hemuns } \\
\end{array}$ \\
\hline Jan. & 150,000 & - & 150,000 & $\operatorname{Jan}=.007$ & 716 & 24,500 & 124.784 \\
\hline $\mathrm{Feb}_{3}$ & - & - & 250.000 & $\mathrm{Feb}=.004$ & 1.258 & 19.000 & 199.812 \\
\hline Mar. & 530,000 & 225,000 & 755.000 & Mar -.007 & 2.304 & 73,500 & 679.196 \\
\hline Apre & 2.077 .250 & $2,342,300$ & 3.613 .200 & $A p r=027$ & 10.794 & 98,000 & $3,304,406$ \\
\hline $5 / 1-5 / 10$ & $3.089,790$ & $1,994 \Omega 980$ & 5.084 .570 & May $=.036$ & 168,243 & 121.990 & 4.794 .337 \\
\hline $5 / 71-5 / 20$ & $3,811,890$ & 2.659 .180 & 6.27 .070 & $-\infty$ & 401,818 & 78.333 & 5.739 .129 \\
\hline $5 / 21-5 / 32$ & 4.351 .990 & 2.806 .384 & 7.158 .374 & $=$ & 722.739 & 78.133 & 6.297 .379 \\
\hline $6 / 2-6 / 20$ & $4.751,050$ & 3.062 .924 & 7.813 .974 & $\operatorname{Jun}=.055$ & $2,0 / 3,661$ & 746.388 & 6.623 .925 \\
\hline $6 / 71-6 / 20$ & $5,025,250$ & $3,329.184$ & 8.354 .434 & $=$ & 1.396 .736 & 18.133 & 6.949 .565 \\
\hline $6 / 27-6 / 30$ & 5.224 .450 & 3.338 .784 & 8.563 .234 & $-\infty$ & $1.724 \times 211$ & 18.133 & 6.830 .890 \\
\hline $7 / 1-7 / 20$ & 5.353 .110 & $=$ & 8.691 .894 & JuI -0080 & 2.206 .266 & 170.786 & $6,614,862$ \\
\hline$(0 / 21-7 / 20$ & $5.429,130$ & - & 8.767 .914 & - & 2.533 .069 & 18.133 & 6.226 .712 \\
\hline $1 / 21-7 / 32$ & $5,480,852$ & $=$ & 8.819 .636 & $-=$ & 2.951 .066 & 18.133 & 5.860 .637 \\
\hline $8 / 1-8 / 20$ & $5.519,412$ & $=$ & 8.858 .296 & $A u g=0053$ & $3.378,278$ & 195.184 & 5.284 .734 \\
\hline $8 / 11-8 / 20$ & 5.561 .112 & $=$ & 8.899 .896 & $-\infty$ & 3.658 .957 & 45,133 & $5,232.806$ \\
\hline $3 / 27-8 / 31$ & $5.584,366$ & $=$ & 8.923 .150 & - & 3.952 .230 & 18.733 & 40962.787 \\
\hline Sep. & $5.607,946$ & - & $8,946,730$ & Sep $=.020$ & 4.294 .349 & 219.582 & $4,432,799$ \\
\hline Deto & 5.643 .844 & $=$ & $8.982,628$ & Oet $=007$ & 40475.187 & 243,398 & 42640043 \\
\hline $\mathrm{Nov}$ & 5.706 .364 & - & $9,045,148$ & Nor $-(0.006)$ & 48678,042 & 268,378 & 4.098 .728 \\
\hline Dec. & $5,780,578$ & $=$ & 9.119 .362 & $D_{e c}=002$ & 4.827 .034 & 292.778 & $3,999,550$ \\
\hline $\begin{array}{l}1950 \\
1954 \\
1956 \\
1957\end{array}$ & $\begin{array}{l}6,072,812 \\
6,384,400 \\
6,768,900 \\
6,555,000\end{array}$ & $\begin{array}{l}\text { These are } \\
\text { compariaor } \\
\text { can occur }\end{array}$ & 2 rather & high freque & $7 \log ^{2}$ & $\begin{array}{l}\text { - years } \\
\text { of the }\end{array}$ & $\begin{array}{l}\text { own. By } \\
\text { ver basins }\end{array}$ \\
\hline
\end{tabular}

\# Reference - Statement C, Table 6, Volume 2 of the 1903-105 Perso-Afghen Arbitration Comenittee Report.

* 1957 Inflow is Interpolated from May thru September. 


\begin{tabular}{|c|c|c|c|c|c|c|c|}
\hline Location & $\begin{array}{l}\text { Axghandab } \\
\text { Afver }\end{array}$ & $\begin{array}{l}\text { Arghestan } \\
\text { River. }\end{array}$ & $\begin{array}{l}\text { Farah } \\
\text { River }\end{array}$ & $\begin{array}{l}\text { Ghesni } \\
\text { Rives }\end{array}$ & $\begin{array}{l}\text { Helmand } \\
\text { Rives }\end{array}$ & $\begin{array}{l}\text { Thesh Pud } \\
\text { Rjver }\end{array}$ & $\begin{array}{l}\text { Tarnak } \\
\text { Rlygr }\end{array}$ \\
\hline ConduotIvisy: & & & & $2 / 9 / 55$ & & & \\
\hline $\begin{array}{l}\text { ECxi0ㅇ } 25^{\circ} \mathrm{C} \\
\% \mathrm{Na} \\
\text { pH } \\
\text { Dissolved Sol1ds }\end{array}$ & $\begin{array}{r}440 \\
24 \\
8.0\end{array}$ & $\begin{array}{r}2107 \\
49 \\
8.5\end{array}$ & $\begin{array}{r}8.45 \\
33 \\
7.7\end{array}$ & $\begin{array}{r}1930 \\
62 \\
7.3\end{array}$ & $\begin{array}{r}320 \\
20 \\
8.3\end{array}$ & $\begin{array}{l}729 \\
8.1\end{array}$ & $\begin{array}{r}1715 \\
63 \\
7.4\end{array}$ \\
\hline 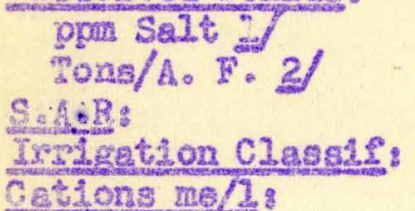 & $\begin{array}{l}321 \\
.42 \\
.80 \\
02524\end{array}$ & $\begin{array}{l}960 \\
2.32 \\
3.75 \\
63=5\end{array}$ & $\begin{array}{l}709 \\
.96 \\
5.25 \\
0.51\end{array}$ & $\begin{array}{r}1300 \\
1.77 \\
6.25 \\
03-52\end{array}$ & $\begin{array}{c}258 \\
.35 \\
.75 \\
c 2=53\end{array}$ & $\begin{array}{l}524 \\
072 \\
2.00 \\
c 2-52\end{array}$ & $\begin{array}{c}1100 \\
1.50 \\
6.2 \\
0.3=32\end{array}$ \\
\hline 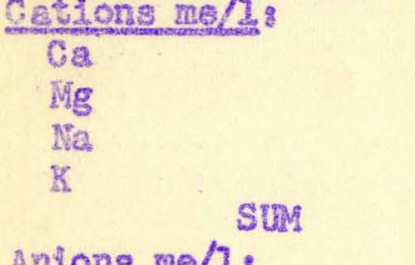 & $\begin{array}{r}2.06 \\
1.20 \\
1.03 \\
.06 \\
4.35 \\
\end{array}$ & $\begin{array}{r}2.02 \\
6.43 \\
7.19 \\
.16 \\
14.80\end{array}$ & $\begin{array}{r}3.38 \\
3.48 \\
3.37 \\
.20 \\
10.33\end{array}$ & $\begin{array}{r}2.50 \\
.4 .54 \\
12.20 \\
.36 \\
29.60\end{array}$ & $\begin{array}{r}1.46 \\
1.26 \\
070 \\
.3 .4 \\
3.56\end{array}$ & $\begin{array}{r}2.14 \\
2.23 \\
3.00 \\
.07 \\
7.44\end{array}$ & $\begin{array}{r}6.44 \\
11.30 \\
.18 \\
17.72\end{array}$ \\
\hline 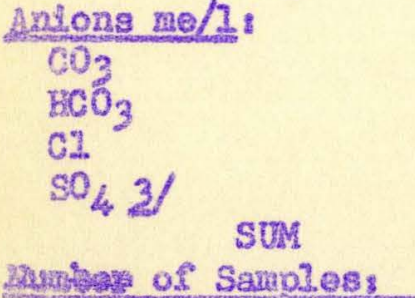 & $\begin{array}{l}.45 \\
3.30 \\
.37 \\
.23 \\
4.35 \\
5\end{array}$ & $\begin{array}{r}1.84 \\
3.65 \\
3.07 \\
6.24 \\
14.80 \\
2\end{array}$ & $\begin{array}{c}.29 \\
5.07 \\
3.29 \\
2.78 \\
10.33 \\
6\end{array}$ & $\begin{array}{c}0 \\
4.95 \\
8.23 \\
6.42 \\
19.60 \\
2\end{array}$ & $\begin{array}{r}.25 \\
2.33 \\
.49 \\
.49 \\
3.56 \\
3\end{array}$ & $\begin{array}{l}.25 \\
4.02 \\
2.07 \\
1.20 \\
7.44 \\
4\end{array}$ & 2 \\
\hline
\end{tabular}

3 Dissolved Solids (ppin) caleulated fros mo/1 z equivalent weight。

2 Tons/A. F。 pors salt $x .00136$.

$3 \mathrm{SO}_{4}$ determined by difference, equals difference botween estions and andons excluding $\mathrm{SO}_{40}$

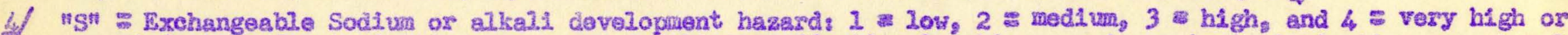

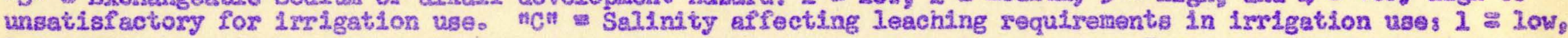
2 mediun, $3 \mathrm{~m} \mathrm{hlgh}$ and not suitable for solis with restriloted drainage, and 4 wery high and ungatigfactory for use except for speclal erops on highty permeable, freely dratned soliso 


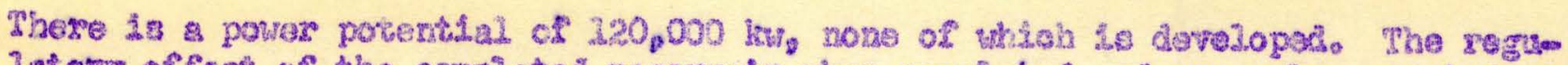

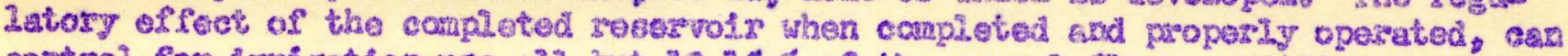

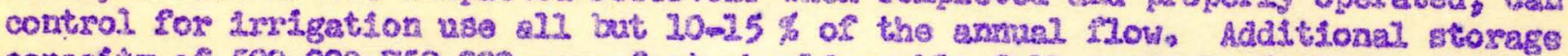

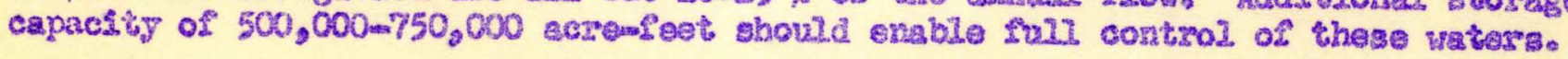

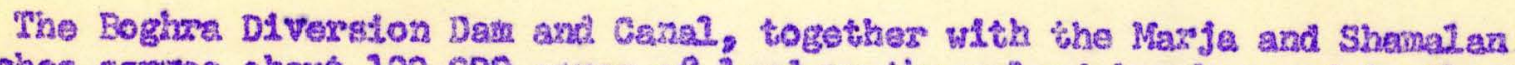
branches sexros about 100,000 abres of Jand on the upland benehes and in the Hel-

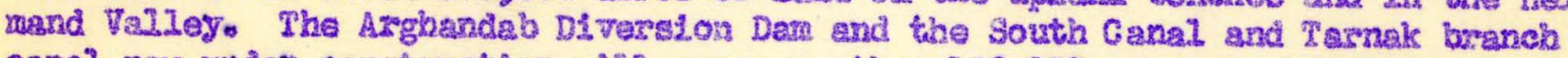
cand now under construction will serve another 120,000 acxes in the uppor

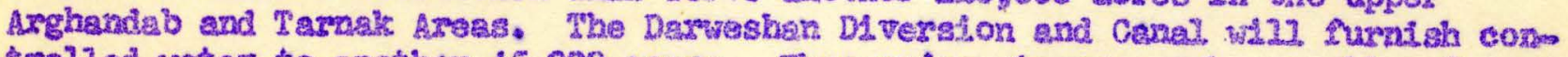
trolled weter to snother 45,000 acres. Thus rajor g'torage works capable of regr. lathing use of over 4,500,000 acrenest of wester and major divargion and cand. งtructuras to imrigate about 265,000 seres of Iands heve boen or are bolng ingtal106.

Development of these Iands to a state whore good crop retuma can be assural

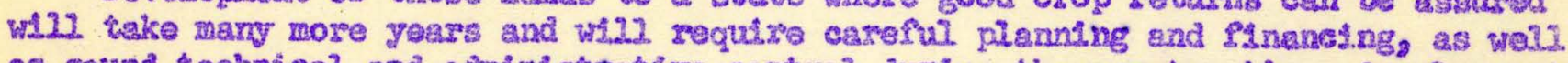

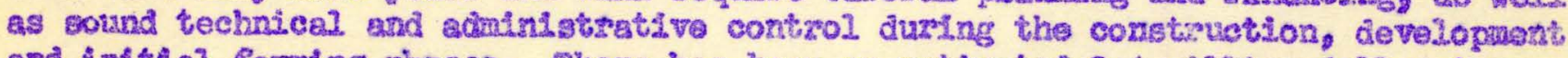

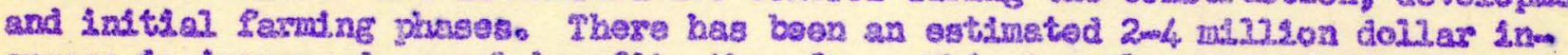

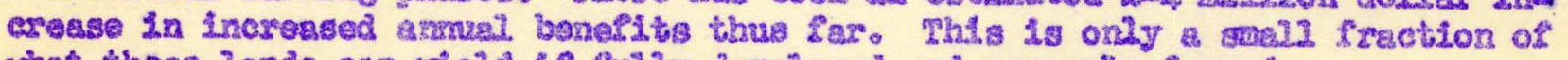

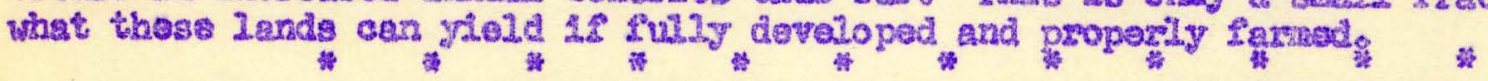

There has been onsidarable difference of optulon over the adrquecy of vetare arpplis for Taxnakefrghandab devajopnent. Wuch of this has resulted beceuse 1955. the year this project devalopnont wss brought forwart for discussion, turned out to

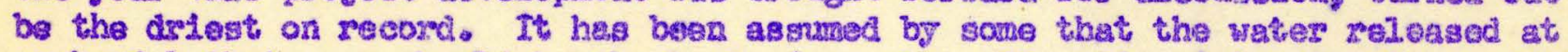
Arghandab thet year should bo the basis for water allocation daterndnatlons. Ihis

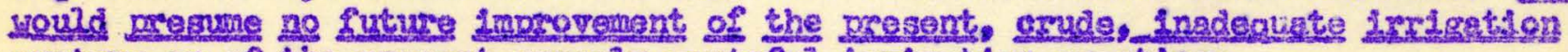

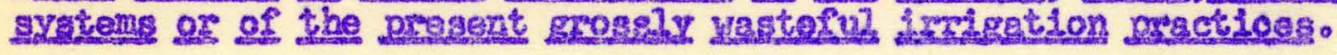

It hes been shown in the above presentation of water resources that 7 yoers out of 10 of wates flow secords and 14 out of 19 of ralnfell records, about $1,225,000$ acrew feet or more then double the dryeyear inflow may be expected. It has also boen ghow that about 500,000 acro-foet of water from other streans anmually nove into and out of the Tamak-A3ghendab area. Thus over 1,500,000 acre-reat is svaliable $70-75 \%$ of the time for development and use on the Iands in questlon. Fiaere Is no arguarent about wator shortage in the dry yeas.

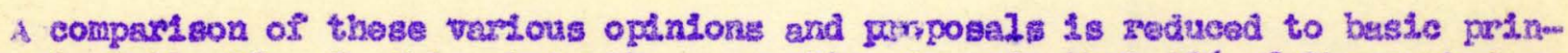
atples in Tabie 35. In this atudy the assunption is made that $20 \%$ of the wasted or unused water" would percolation losses. The soils in gexesel are deap to vory deep loams to s1lty elay lowas of high waterholring capacity and slow to modexate

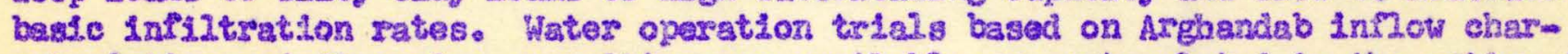

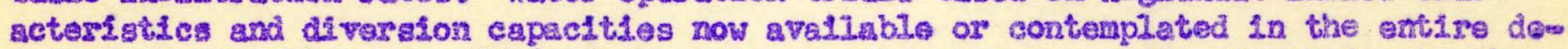
velopaent ahow that ovar $90 \%$ of the wrter on the average can be divertad onto the 1and. After deducting normaly expectad reservols ovaporation losses the distribu tion of use of the avaliabie wato is shown in 2able 35.

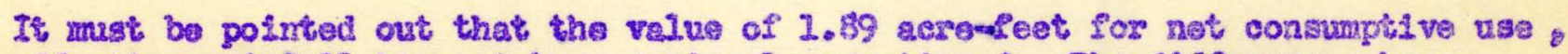
loss effective reinta11, has not ben seriously questioned. The differeaces have

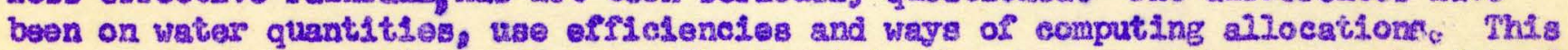
value and total quantities of water Ilowing into the area are taken as baeic data for the conclustons reached in table 35 . 

SRD BY DTHEERENI ANAIYSES *

\begin{tabular}{|c|c|c|c|c|c|c|c|}
\hline 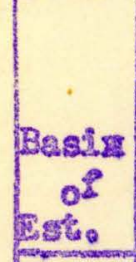 & $\begin{array}{l}\text { Eatirested that } \\
\text { bater is avali- } \\
\text { able for the fol- } \\
\text { lowing situations }\end{array}$ & 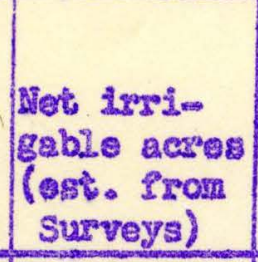 & 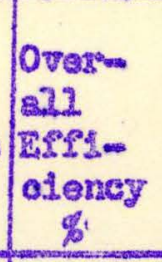 & 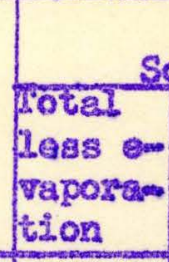 & $\begin{array}{l}\text { Wastage of } \\
\text { ehemes } 4 \text { n } \\
\text { by parcom } \\
2 \text { ation } \\
0 \\
20 \%\end{array}$ & $\begin{array}{l}\text { Water } \\
\text { Aore-fes } \\
\text { By } \\
\text { Runoff }\end{array}$ & $\begin{array}{l}\text { by Vartous } \\
\text { ot per Acre } \\
\text { Grass Wastage } \\
\text { In acre-foet } \\
\text { of runoff and } \\
\text { furether evaporation }\end{array}$ \\
\hline & 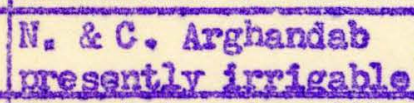 & 126.728 & 15.8 & 120.20 & 2.02 & 18.08 & 1243,000 \\
\hline & $\begin{array}{l}\text { Same butt only with } \\
\text { uschondib wate }\end{array}$ & $n$ & 12.2 & 729 & 1.60 & 6.39 & 745.900 \\
\hline & $\begin{array}{l}\text { N. } 7 \mathrm{G}_{\text {. }} \text { Lower } \\
\text { Arghondab }\end{array}$ & 1222.642 & 26.6 & 2.52 & 1.90 & 7.60 & 232,000 \\
\hline & 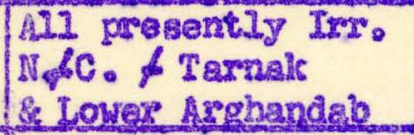 & 177.583 & 29.2 & 4060 & 0.22 & 3,68 & 653.500 \\
\hline 2 & Max. Acreage & 193,000 & 26.0 & 5.36 & 1.07 & 4029 & $828_{3} 000$ \\
\hline 8 & 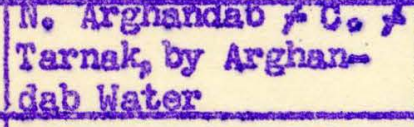 & 185,000 & 30.3 & 14.34 & 0.87 & 3.47 & 642,000 \\
\hline
\end{tabular}

* Basio Data: (8) I, 229,883 acre-feet inflow in 7 years out of 10 with maximum usable divarsion of $1,153,380$ arreieat (Table XXI110, June 2, 1957, revision of Water Alm locations Report). (b) Net mean per acre evapoptzanspiration less ueabie rainfall : I.89 acreniset (Tible XV, above report). (c) Avg. flow measursd at Charharburfak, contributed by other streans (2able 24 of this report).

y Dse of total inflow of $1,500,000$ acre-feet lass 200,000 for evaporation losses and spisi.

2/ Dse of present Iacilities and of Arghandab Infiow Less ovaporation less apil1. 
If only the presently irrigable lands of $N_{0}$ \& C . Arghandab are developed8.00 acrenfeet per asre of watex based on the Arghandab outflow and 10.0 acre-feet/ acrę bssed on total stream flow Into the projects will be wasted as percolation or runoff. If all lands now usable for irrigation in the No \& Central Arghandab, lower Axghandab and Tarnaik (total surveyed areas) were irrigated, 406 acre-seet/acre would st1l1 be wasted considering only Arghandab water and 5.96, considering all apparently available surface waters. If the maximum acreage potentially suitable for irrigation were reclained and developed to Its fullest practical use (150\% doublemcropping) as outlined in the vater a.llocations study 5.36 acre-feet per acre would still be wasted. These various schemes show net overall use efficiencies of $16-29 \%$ disregarding reservoir evaporetion $10 s s e{ }_{0}$

The water allocation study which hes bsen the besis for irrigation design 1 in the Tarnalk Arghandab development takse tho stand that 285,000 acres can be fully Irrigated from Arghandab water 7 yearg out of 10 or 14 out of 19 according to the records. The net overall efflciency, disxagarding reservolr evaporation is $30.3 \%$. It was pointed out in the a.17ocation study that the aljecations were predicated on overy effort being made by the government and the people to achieve sound water use regulationsito Lmprove and modernize oxisting imeigation distribution systems to carry out oducation and demongtration and on-famm-training to encourage efficlent use of water as woll as improved agrieultural methods. Even so it can be seen that 640,000 aere-feet or about one-helf of all the Arghandab water would sti1] 11kely be wasted runoff and further parcolation into low-lying areas, waste drains and stream channels. It was pointed out in the water allocation study that several streans, parallal to and through the entire length of the Arghandab-Tarnak land areas, ... offer opportunities for picking up and reusing this waste flow. For the emire systen, to the proposed Seraj branch canal, over 500,000 acre-feet could be avallable for diversion and reuse. If reused at the same efficlency of $30.3 \%$ the net return flow usage could be $40 \%$ or be equivalent to another 75,000 acres of land.

It appear: utile, therefore to contime discussing the water shortages. Certainly about 1 year out of 4 there will. be a shortage unless additional reserw volr storage is developed. However $75 \%$ of the years can produce their full amount and the land will produce 75095\% even in the dry years. Assuming $50 \%$ yleld in dxy years the income ratio in favor of the larger acreage 1s 1.35:2. The government must deelde whether it wanks to aggravate past wasteful nethods and furthor waterlog and salinize the lentrel and $N$. Arghendab Aress, $4 g_{9} 000$ acres of which is already too saline-alkell to grow erops or spread the water more evenly over larger acreage and thus reduce the dangers of waterlogging as well as encourage more efrleient uss and, in the long mu, reap greater economic retumso

To satlaly those who are further concerned with soundness of these water al20

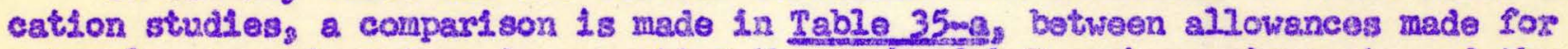
water losses and wastage in computing the Arghandab-Tarnak requirements and the rango of 10 sses and vastes reported by Houk as commonly experienced in irrigation projects of the states.

By comparison it san be seen that the allowances for wastage are generally above the middle of the ranges quoted by Houk and the proposed afflclencies of use well within the ranges he quoted. The use of $5 \%$ return fow is far bolow the minlmum quoted by Houk and in view of the fact that $95 \%$ as much water is passing the Kala BLst station as waste flow as leaves the Arghandab Reservoir, return flow could easily be a much higher figurs. 
It has been repeatedly stated that oven these allowances are predicated on malcing substantial improvenents over a period of years in the Afghan 1rrigation and drainage systems, water management, and Irrigation practices. Every effort has been made to keep these studles on a sound engineering and egronoric basisa 


\section{Durting Delivery}

Average fileld evaporation before topsoil dries Surfice wasto, allowance for large project: Sessonal percolation losses, except on porous solls Losses of flow in farm ditches Deliveries to farms (see Chapter 11)

Cons. use, divarsifled erops (see Ghapter 10) Irrigation efflclencles, cormon farm crops Irrigation officiencies, fruit and special crops

Avg. Irrigation officiencies on large projects

\section{During Converance}

Evaporation from canal surfaces

Evapo-transpiration at canal banks

Canal seepage, large projects, mostiy unlined canala Seepage losses, most canels lined

waste on large projects, ample wator supplios

Waste on large projects, 11nfted water suppl1es

over-all efficlencles, large projects

Diversiona for large projects (see Chapter 11)

2) Roturn flow for large projects

1/From Irrigation Engineering, Volume Is Chepter 12,

Page 392 by Ivan $\Sigma_{\text {. }}$. Houk, Consulting Englneer

Denver, Colorado

2/1bid pages $412-418$
COMMON EXPERTENCE REPORTED I

0.5 inch per irrigation

10 per cent of diversions

$0-1.5$ acreafoet per acre

5-50 por cent per wile

1-7 acro feet per acre

103.5 scre-feet per ecre

20-50 per cent

35-70 per cent

$30-50$ per cent

\section{Negligiblo}

\section{Negligible}

15-45 per cent of diversions

5-15 per cent of diversions

5-30 per cent of divergions

1-10 per cent of diversions

$20=35$ per cent

2-10 acre-feet per sore

I-3 acre-feet/acro, 50 $=65 \%$ rem usable. $25-50 \%$ gross diver.

\section{EST IMATES USED FOR ARGHANDAB-TARNAK AREA 3 During Delivery}

$0.5^{\text {m }}$ in。 per irr。 in hot sesgon

$26.4 \%$ (used as part of farm 1rro 10ss)

0.87 acre-feet (2) $14 \%$ of gross

(heavy to med。 so118) $10 \%$ ( $4 \%$ of gross)

2.71 (.263) 4.17 (avgo): $4099(.737$ )

$2.25 \mathrm{~A} . \mathrm{F}$ /ACre

$35-50 \%$ on diff. soll types

$45-65 \%$ on diff. soll types

$35-65 \%$ all soils, mean above \$ $37.95 \%$

\section{During Converance}

Nogligible

Negligible

Main canal Iined

Used $15 \%$

Restricted supplies 26.3\% of yoars

Used $5-8 \%$

$43 \%(0263): 3405 \%(\mathrm{avg}): 28.8 \%(0.37)$

$3.25 \%(.263) ; 5.21 \%$ (avgo); $6.23 \%(.737)$

$5 \%$ of gross diveraion reusablo

3. From Arghandab-Tarnak Water A.17oca Lons

Study, MKAo, 1956

3/NOTE: The ostinates are based on complote devolopment, rehabilitation of old systems, sownd water management and education and demonstration of inproved irrigation techniques among the farmers. Present overall offleiency oalculated st 16\%. 


\section{SOTH RESOURCES:}

\section{Soll Survez Report and Mapg.}

8. How 2 soll gurroy is made. Solls survey and land classf fleatlon.

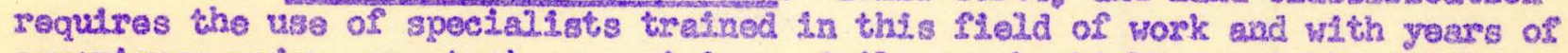
expertence under competent supervision. Solls may be highly varlabie su chasaco ter and change remaskably in short distaneos or by conksest may be quite un form over considerable area and for several foat downard The influences of cllnato, topography and vegetation acking over a pertod of tine on a given geologle-source matorial will produco recogniobile soll chasacterlstics which more or leøs conm sistenty repeet thenselvas and so can bo classiflod. Whthin these broad jxa 12uences, however, wide local vardations occur whi.ch af fect plant adaptation and grouth, and sol1 managonent reçutrements. Since production of erops is the

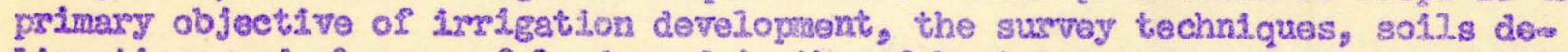
Iineations and c?asses of land used Lin the Afghentstan surveys are necassarliy utilltirlan in objoctive. The standards emplojed and legends used aro adepted from procedures and gtandards of solis survey and land olassifleatLon of tho U. S. Dopartment of Agriculture, Soll Gonservation Sorvlce and tho V. S. Dopartment of Intertor, Bureau of Reclamet1on. Certein modifications are made locally as needed and are explained In the Survoy Marusl for Helrond Valuloy Surm veys。

Bringy, the trained soll surveyor systematheally traverses and exralnes a parcel of land at regular interval depanding on the detell of Invostigation rea quired. Aerlal photos of 1.8000 scale are used for detalled woris and $2.20,000$ for

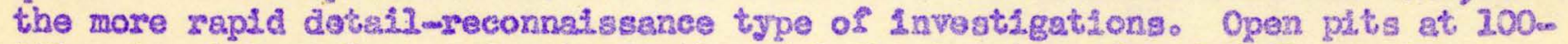

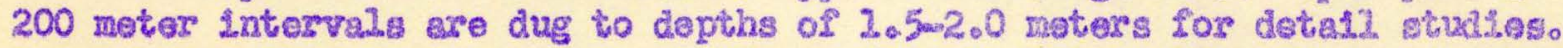
Augers and spades are used to got eloser detall. The soll hortzons oxpowed by

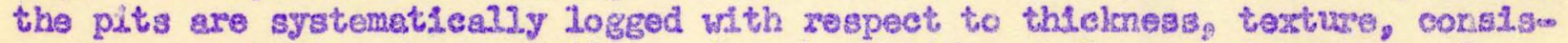
tence, structure and permeablilty of each stgrifseant layor. Notatlons of spocial teatures much as presence of gravel, 11ws, selts, alkais, gypaum, end watertables are noted. Any tendency toward compsction and conentetion 13 ro corded. The growth and character of plants and plant roots la studlod as a key to the soll. ability to grow crops. Surface features, slope, erosion, mresent land use and types and appearanco of vegetation all are considdared ms clues to those cheracteristics of the land which wi13 affect ixr1gation agricultur. Samples of sol1 hor'zons are sent to the laboratory for enalyses and these rom sults are used in conjunction with the field observations to establish a fins? decision as to the solls proper symbol characterization on the mapo

Solis and drainsbility survege are made coneuxrently In Afghaniatan so that

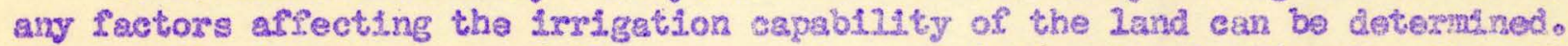
The detall of this phase of the surveys 1 s axplatned under Section $V$. When ths

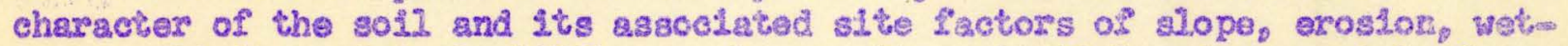

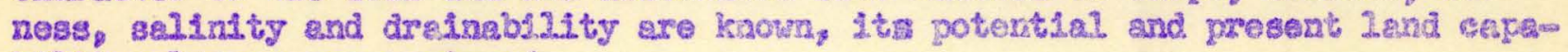
bility classes are asılgned.

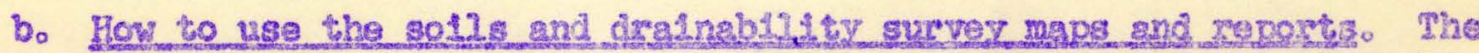

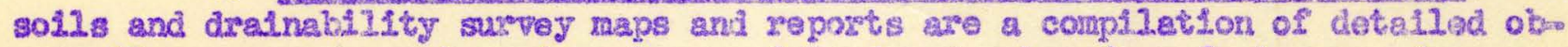
servatLons, measurements and ansiysss of 1and and subsurisce fertures and rege-

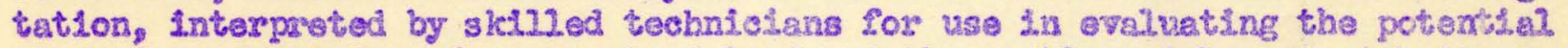
use and productivity of a pareel of land and the problems lnhorent whth ita des velopranto 


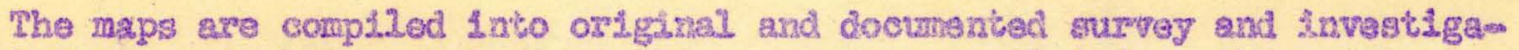

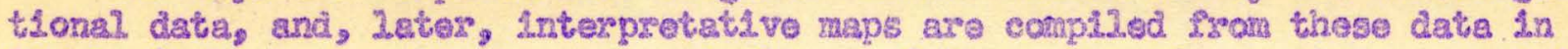
IIght of the known clImate and agriculture of the area and exparience on similar solis and land conditions.

Survey Marrual).

(1) Beate Data (Shown by symbols deseribed In detall In the

(a) The Soll Survey ghowe:

As Base map fogtures.

1. Roads, V1Ileges, Rurnso

2. Drelinage.

(a) stroans clamstried as to perennial or Interzttent character.

(b) Waghes.

(c) Guzlios.

3. Irrigation and treanago struotures (ff cone gtrugted at tho of survey).

4. NTaturea? land fomtux?

(a) Nountelns, hills and rock outerops.

(b) Dunes and sand dreffis.

(c) Narshes, swernps, 1akes.

(d) other significant features.

\section{B. Features shown by Suxver Symbols.}

1. So11s; Depth, texture of sursece soll, subw

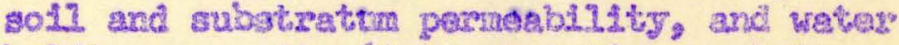
holding aapactiy (intorysetative symbols based on toxture, strzeture, conslstence, porosity and on orgenic msther, grpsum and Iime content of each signifleant horlaon)。

2. Assoglated os glte Iactogs Sal1ntby alkan Intity, presence of gravels and stones, pres. ence and degkh to groundustier.

3. Topography: Degreo of Blope, and degree of Fegularlty or unevanness of slope (actusi. Iand alevation contous's show oniy on topos graphle survag base)。

4. Ezoston sind Frod 1bility: Degres and kinds of

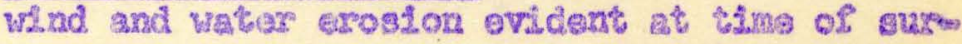
voy - R2so tendency to arode 18 intorgroted. from the composite symbol.

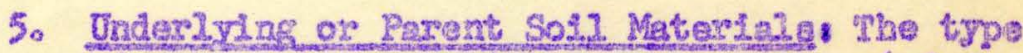
of wnderighng netorials within a 5 or 6 moot depth ax noted as they affect soli character, drasnability and plart grouth. These are gove

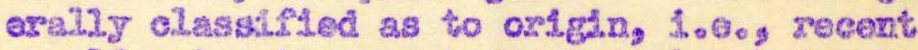

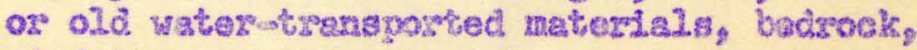

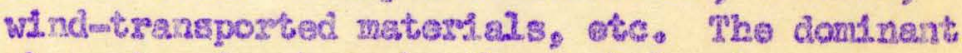
charecte: 1 s shorn by the gymbols, 1. $\theta_{0}$ I = 1.tmstone, $z=$ gravel, gto. 
6. Pxosent hand Vse: The use of the land for PLeld crops, orcherds or vineyards is noted. If in natural vegetation the general type is show. Some lands are barren (fallow) or abandoned. AI1 these give cluss to present soll conditions and are userul In plaming future work.

C. Spscis? Location Symbols.

1. Triangulation points and bench marks.

2. Deep pits for soils and drainage studies and anipling of solis.

3. Location and identificetion of somplos anelyzed in the leboratory.

4. Locstion of fiald tosts such as Infiltiation tests and leaching trats.

(b) The Drainabil1tid Surgey:

The drefrability survey is concernad primarliy with those subsurface festures which dotormine the relative eese or diffj.culty of romoving waters lost by per solan tion and of maintaining groundueter tables ot depths which vill permit agricultural use of the land. In the form of pit logs, meps, grephs, charts and tables the bastc sleld data includes:

\section{A. Logs of Substzatur Materielg.}

A systematic logging of materials to dopths of several neter's to determine the depth, thiclcness and permeability of aquifors, the depth to and character of barylers to downard novenant of wates" the presence or absence of watertables and the hyaraulic conductivity of satureted zones.

\section{B. Ground Water Measurenent:}

By means of plts, open wolls, perforated plpe, the watertable levels are observed periodicaly to der termine fluctugtions with seasonal cond1tfons of irrigation, xainiall and dry perlods. Plozonotars are used where nocessary.

G. Elevation and Topograday Measurements.

The olevations of each pit, wall or $p 1 p e$ and tholr bench maxks and measuring polnts ars accurately des termined and tiod Into the area topographic base rupso 


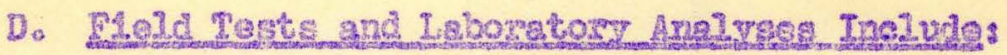

2. Mossurement of hydrzulte conductivity oริ ตgtน rated zones.

2. Chenteal analyses of groundwater.

3. Mechanical \& parmesbility analyses of vartous subatratum horizons.

4. Rate of flow mogsurenexts of extating dradns.

E. AlI of the above dete Is compliled for presentation In the forn of chrits and meps and tablas showing:

1. Depth to and slope of very slowiy parmeable or impervious lagers.

2. Thickneas, deptb to and hydraxile conductivity of possible squifers.

3. Depth to and slope of existing watertables.

4. Thuetuations of watertables w1th seasonal 1motm gation and rainfall.

5. quality of groundwater.

6. Fou of groundwater in extsting drains.

\section{(2) Interpretation of Data:}

Interpretative Hog (Conarally in colors or hschures) shou the broad groupings or classiflestions made for spesisic use purgoses from careful wolghing of all lects assenbled by the aurvey. The following are avaliabio or can be made raom tho soila and dratnebility suxveys.

Ae From the Solis survey Mans (aftor correlation with dadrablisty raps).

1. Gerreral or project selection end layout.

a. Land eapabil1ty classes (naps \& tablaa).

(2) Present.

(2) Potential.

b. Project map showling boundary and Lands which ase

(1) Prosextly irrigeble,

(2) Irrigable when reclalmed,

(3) Wo recommended for development. 
2. Land Dovelogngent Problen Aresso

a. Land clearting map showing

(1) Crop land

(2) Brush and grass land

(3) Barren (abandoned) Iand

b. Land levaling map showing selativo degrees of leveling required

c. Map of wot lands needing drainage now, show ing relative degrees of wetness

d. Map of lands needing leachlng of salts showing relative concentrations of galt

๑. Map of lands needing alkali treatment

f. Map of lands needing deep plowling of sands or other sand control works

3. Irrigation Dasion and Ityout.

a. Water seçulrements map showing TRAM capaeltles and acres por cfs data for subleteral design.

b. Table of farm Ixylgetion layout requirem ments by soll bypos, 1.0., lengths and widths of borders end irrigation bowd for different TRAM and Infiltration conditsons

40 Farm Iayout and Water A1 locgtions.

8. Laad capability clesses (abovo)

b. Crop adaptations meps, charts and tables

c. Tabies of monthly 1rzigation requirementis for crops fitting each major land cless and so12 group and psobablo wator allocam tions by land axeas and types of faxns.

B. From the Drainabj3.1ty Maos and Charts and copogrephte Dats:

1. General project layout of project main and colw lectos dralns.

2. Sub-collector drains and farm drains (typo, depths, spacings, direction and slope of dralus Is worked out Iater in deta11 for each 20cal cons dition as the need for and construetion of draint progresser) o 
3. Slow or difficult areas which mey need special attention or may Justipy being deferred or omitted from project developm ment beceuse of costs and probable low agxicul.turg. jetuxns.

4. Data for predicting the lovel of drainage it is practical to achieve in any given aree (rnay deterrine selection of arops for the solis of the area).

\section{IAND CLASSIEICATION}

Agricultural classification of land is designed to rellect lts sultability for Irrigation for growth of erops and 1ts productivity potentilels and general land values. While several sehemes of classification are in use by different agencies, none of these appeared to quite fit the needs for developruent of lands in Afghanistan. The following schere of classification enjodies the principles used in the severa. land classifications now in wogue, but speciel adaptations have been made to fit conditions which prevali in Afghenistan with respect to physical. conditions of land and climate.

The principle followed is that perinanent, nonmanovable (frorn a practieal stand-s point) asecurrent characteristies of the sols and its associated factors are classifled th the degree to which they Linnt the use capebility of the land. Temporary or rercovable Iimitations such as loose rock, brush, or tree growth, uneven surface conditlons requiring levelling, ase considered ss temporaxy linita tions affecting the cost of developmeat only. These are not permanent land fexm tures affecting land use eapability unless so extreme that land development is impract1cal. However, it is expected that costs of development will be considered for 273 classes of land and their present condjtions In relation to the economie and social need for developing the land and the expected benefits to be derived.

CLASS I (Green color on solls maps): Iand which is suttable for Ixrigation of all cimatically adapted crops with no restrietions in use other than good irrigation farming practiees. Such practices include the use of good rotations with soilbrilding crops. The use of moderate amounts of manures and commereial sertilizar's may be required for high ylelds but falr to good ylelds cen be maintained for a long period of time with minimun fertilith managenent. putine smoothing and Iloat, ing for seed bed preparation and irrigation is a regular practlce. Surface draln age coupled with efficlent use of water should normally meintain the soil in a wellodrained condition. Surface soils should be easlly t111ed with no spectal treatment necessary to control crusting, selts or alkali. Class I sol.ls are deep and roots, ais and water penetrate well; yet the water holding eapect.ty is good. Topographic conditions are commonly such that land development is relathively easy.

CLASS II (Yellow color on soils maps): Land which is sutable for iryigatton of a majority of the cilmaticaily adarted crops but has one ox more permanent limitations which require practlees in adojtion to good ixrlgation farming nethods to maintain productivity. Generaly Class II lands wiIl be less productive, be adepted to a narrower range of crops, be more expensive to develop, or be more costly to farn than Class I lands. Special practices which mey be required include: (1) Wind 
or weter erosion control, (2) Special irrlgation developuant such as bench leveling. and irgigetion methods such as contour irrigetion and restricted use, (3) Special. tillage operations to correct surface crusting on hard pan layors, (4) Correctlon of low fertilyty by spectal application of fertilizers or soli mendments, a nd (5) improvement of surface and subsoll dratnage and removal and control of salts. Such improvements when accomplished should result in higher sustained jields.

CLASS ITI (Red color on soj.1s nags): Land which is suitable for iryigation of a Iimited number of climatically adapted crops and generally reculires special treato ments and continzzus practilees to overcone major defieloncies and maintain ylelds. Generally, these are Iands of restricted suitability gequiring careful management for fair to good ylelds of adapted crops. Major drainage measures such as deep open ditches and open or thle drains may be needed. Recurring recianation practicses to control salinity and alkalinity may be requixed. Other measures nay ineiude special and extensive levelling such as bench terracing and contour lrrigation of steep slopes. Some solis of this class have such lower weter holding capacity and high pexmeablilty that irxigation must be frecuent and with high hesds and short rwus. Solis with low fertility requiring continuous use of large quantities of fertillzers will be placed in this class. Class III ineludes some lands subject to periodic danging overllows but otherwlse productive.

CLASS IV (BIue color on soils maps): Land which is not suitable for contimuous Irrigation of common imrigated crops but mey have lintted use for some of these crops. If properiy developed, it can be irrigated safely and whth fair to good yields when in vegetation such as trees for woodland products or gresses and 20 gumes for hay or pasture. Such lands may be too shallow, too steep, too frequently overflowed or remain too wet, saline or alkaline for prectleal or economie use as regular cropland. Under special situations, such as abundant available water supplies, imLgation to produce treesior Ivel or forage for livestock may be Justio fied, or special exops adapted to the extreme limtitations of the Iand.

CIASS V (Brown color on soils maps): Land which is unsulted for Irrygation of any exops. Such lands include steep or broken areas, nountains, river wash, stipeax beds, extremely rocky or gravelly soils, sanc dunes, narshes, and salt or alkall flats not practical to reclaim. Unusual and spectal uses of weter may have value on some of these lands, however, such as the flooding of marshes to maintain food for wid iffe。

\section{CHARACTERISTICS OF SOUMHUES" AFCHANISTAN SOIIS WHICH AFFECT DEVTIOPMENT. USE AND MANAGCNENT DE IAND RESOURCES.}

A large proportion of the potentLajy Irrigable lands have been exanined. General or exploratory recomalssance solls surveys have covered well over 2.5 milion acres in search of possible Iands for development. Reconnaissance soil. and drainage surveys have covered 678,135 acses, sem-detalled surveys have covered 464,335 and detaj1 sed swreys 577,786 acres as measured from maps on Plie.

It is impossible to glve more than a very general picture here of the solla end land conditions found in these surveys and studies. Supplemental zeports covering each project area in more detail have been prepared and are avallable to those who wish to study these areas in detail. A general sumaxy of soll condlitons is presented here.

$a_{0}$ General osigin and development of soils. The solis of nost of the potentially arable lands are developing from alluvilil and aeollan materlals. The original bedrock sources are the uplifts of the Hindurush and Its westuard ranges the Koh-i-Baba and 
Parapoifsus. These sre rugged, genera.1y barren rocks rifing to 25 , coo feet in the extreme northeast and dropping gradualiy to $8000-12,000$ 2eet in the western part of the country near Herat. Extrome tilting, folding and wamping in them is evidence of the pressures exterted during the uplift. Glacial and postmglacial movement of materials from these uplifts cover upwards of 60,000 square miles to the south and southwest of the mountains and foothilis.

(1) Desert Plains So13.s - The Dasht-1-Hargo Iyjing north of the great 20op of the Helmand (see Map D-17 R 4 ) consists for the most part of very thin reddish desert soils over outwash grevels highly impregnated with ine. Gypsum beds occuse only a few inches below the suriace in many places. A few areas in this vast, relatively barren desert, have accumulated a surfictently thick nantle of solit to afford some promise of agricultural. use. The deeper desert solis have in many places a very compact, reddish brown, sendy elay loam lower subsoil which is slowly permeable. Over-irrigation of the more permeable upper horizons has resulted in perched water tables and salinizing of these lands by capillary movenent of saline waters to the suriace. Compection and cenentation in all degrees is found in these desert soils. Cementing agencies appear to be calcium carbonate, silleates and in a. few places iron oxides. Cenented layers vary widely in thickness, textrure and density. Caliches, Iime-cemented sandstones, shales and a layer of conglomerate, (slitica and lime cemented outwash grevel and cobble), is common at depths of lon neters under the surface. This material is so dense it resembles concrete and when rewoved often breaks across the natural rock rather than through the cementing matrit: These relatively impervious rocks pose a sertous drainage problen for most desert 3011.30 far examined. Only where these rocks lie sufficientiy deep and more open gravels and sands occur above them have drainage of the irrlgated lands on the desert plains been reasonably adequate.

Considereble agricultural use $1 \mathrm{~s}$ being made of these solls with varylag degreas of success. The Marje project 27,000 acres, Nadei-Ali or Boghra Pro ject 18, 500 acres and parts of the Seraj project 60,000 acres, North Arghandab 25,000 acres, and Tamak project 28,000 acres are red desert solis on outwash plains materials and underlain at varying depths by cement/8\% compacted 2ayers, herdpans, or conglonerate. The Bakwa area Iying between the Khash and $F$ arah Rivers at the base of the KohmolBaba range is underlald by conglomerate throughout a large part of the area surveyed. In general here, however, the soils are thicker and more continuously deeper than in the deserts projects mentioned above.

Textures, depth and permeablilty vary widely. The highest proportion are thin solls with graylish brown or weak reddish brown silt loam, loan or fine sand loam surface solis over thin to moderately thick reditsh brown loan to sandy clay loan subsolls contalning varying amounts of gravel. Iime in soft concretions is common. Some soils have thick lajers of caleium carbonate of vazying degrees of harcinesi. Often slight wises or knoijigin an otherwse smoothily sloping lendscape will consist of thin, gravelly and comnonly highly saline solls over beds of crystalilne gypsum interspersed with gravels and sands. The "gotch" pockets are very rapidily permeable and have little capaclty to hold water. Consequently, irrigation and ditch waters are quiekly lost by percolation. Salts are common in the gravelly desert solls, the concentrations varying from $0.5 \%$ - $3.0 \%$ in the surface foot of area/examined. These are chiefly chlorides, sulphates, and bicarbonates. Very few desert soils appear to be strongly ajkaline. Soluble carbonates are low.

In the surveys selection of potentlaliy arable lands has been difficult because of the substratum drainability. Solis selected for adequate depth, molsture retention, 


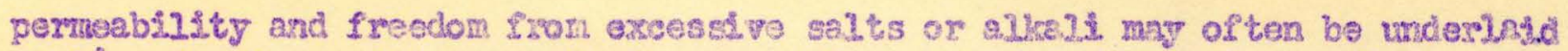

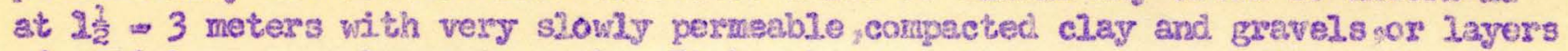
of caliche or conglomerate rock. It has been necessary concurrently with and. following the solis surveys to wake intensive subsurface explorations by means of open pits hand dug to rock or to depths of 3-4 meters. Solis having slowly drainable substratum conditions are $11 k e l y$ to be difficult and costly to develop. Maintenance of suffleient downway novenent of weter through the soil and into outlet drains to counteract capillaxy rise of saline groundwaters is necessary for successful erop production. Unless such conditions can be met within reasonable costs, classiflcation of such soll areas is made to reflect these problems of development.

Another problem of development less serious as a whole but locally vexy important in these desent plains is that of wind-erosion. At certain periods of the year strong winds sweep across the deserts, causing considerable movenent and sorting of soli particles. Vast dunes are footioose on the barren deserts where they have aggregated from wide areas. The general dune movement varies with the relative shifing of the wind directions. The strongest and most continuous winds sweep down across the Chakansureniestan basin in a south-southwest directlon. Some influence from the wountain ranges southward in Baluchlstan and the winds woving ine ward from the Perstan Guaf cause a major shift in direction so that the and movement shifts more esstward across the lower Dasht-1-Nargo and the Reglstan, a vast dune-covered desert south of the Helmand, and continwes eastward until the 6000 . 8000 foot ranges in Paklstan force the winds to rise and drop their sands near the Afghan Pallistan border. The winds seem to move nomheasterly here and the finer sediments are dropped in the upper plains and valleys such as the upper Tarnak plain near Mulux. Here s116s, apperent.y of aeolian origin, are many feet in thickness over a large area. Other wrtters have described this grading and sorting process which is so strongly evident from study of aerial photographs of the lower Helmand, the Chalsansur, and the Reglstas.

The hazards of project developnent are culte apparent where dunes are fin novement on the windward side of irreigation and drainege structures. This is a serious probiem in parts of the lower Marja, the central Darweshan, lower Shamalan, Garmsel and Chakansur areas. More detailed studies are needed to determine the rate of movement of sands, and costs of maintaining structures where choking of canals or drains occur. Means of control will be discussed in the chapter on ixrigation farming practices.

Soll fertility is another desert soll problex. Many of the sandier types and thin, more gravelly soils are low in avallable phosphate. Tests repeatedly show this to be true in the Nad-1-AlI area. Organic and nitrogen are bypically low in most desert solls but these can be maintained at a fair level, by good rotations, use of legumes and animal manures. The supplying of phosphate fertilizers constitutes a definite problem for the future, however. Preliminary minerel surveys have failed to reveal sources within the country. This is one investigation that should be conitingt as an improved and sustained productivity of these desert soils will require the use of phosphate fertlilizers.

(2) The soils of the recent tercaces and valley fills.

By far the more promising lands for imigation development are the deep valley fill and river terrace solls lying between the Arghandab and Dorl rivers, along the Arghandab and Helmand valleys and to a lesser extent in the valleys of the Farah and Khash. Eximaliva areas of silts of mixed loessial and aliuvial origin oceur in the 
uppe: Tarnak plains near Mukur but are not included as a part of the Helmand Vai.loy Development program.

The Valley Iill solis represent the gradual accumulation of olluvial sediment together with wind-laid materials at the lower extremtitios of long outwash slopes and fans and above the more recent stream terraces. The Arghandab and Ternak Areas are the laxgest of these. 2wo narrow but steep, rugged uplifts zun southwesterly along the sest side of the present Arghandab and vestside of the present Tamak channels. These uplifts together with the hills and high bluffs of the Reglitan Iying south of the present Dor'-Arghandab channels have slowed down waters woving outward Irom the desert Ians and slopes Iong enough to have built up large areas of thick slits, fino sands, and clays. Those solis becone thinner toward tho upper slopes uat1.1 thoy bocone indistinguishable from the true rodish desert out-m wash plains sol1s. In the upper reaches the compact reddish brown subsolls of the desart plains sol1s extend uaderneath these later, less weathered deposits. Irri. gation with silt-laden waters during high runofi has through the centuries built thiel leyers of silts and I1ne sands ovar the original soll. S. Strat1fication of thin soil Iayer: ig cormon in these older irrigated sections.

In genaral the valley SIII solls are deep, noderately 11 ght brown to very pale brown ailt loams and fine sandy loams with silt loen to silty clay loam sub solli. Soll structure varies depending on the manner in which the soils wero latd down and devaloped. Whore stratifled with thin lenses of compact, massive, silty clays, the pernesbility is low, The more uniforn profilos, perticularly those with woakly grismatic to nuclform structure are nore permeablo and better drained. UnderIydng materdals vary from the red desert solis and outwash gravels to more recent 2lluvial gravels and sands. In some areas, as in the low flats extending southwest fron Kandahar, deposits of silty clays and silts extend to over 4 meters in places. Drainability varies widely from place to plece. A part of the lower benches of the N. Arghandab project, the long, low flats through the Central Arghandab and a part of the central and Lower slit plains of the Tarnak and Central Arghandab, adjacent to the Tasrak 1ver, have such thick a11t deposits that drainage will be a serious probilem if excess waters are wastod in and above these areas. In addition to the

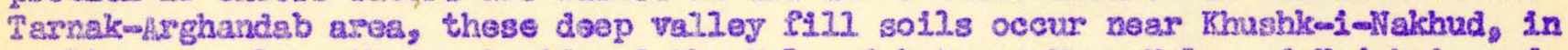
आrall aress along the west side of the Helmand between Mrse Kala and Kajaka1, and ajong the upper Farah. There are no doubt other places not yet surveyed or ob maxved.

The more recent series of terraces and benches along the various rivers con stitute fraportant agricultugal aress. Dominanty the solis are deep, lightwcolored slit, loans, loans and very Iine sendy loams. Along the Helnand considerable areas of unifornily sandy s012s, sandy looms to loamy fine sands, also occus. Some of the older tarrecas have accumulated, through past uss of silt-laden waters, several feet of silts, fine sands and clays. 0ld pottery shards occur extensively under the Shameilan terrace soils at about one mater depth. Pert of this deposition is prob abiy due to a period of beavy Llood deposition, sinee the shards do not contimue up ward through the profile. Some payts of the terrace benches along the Arghandab and Holnand are heavy silty clay loams and silty clays severel feet in thickness. These do not drain woll and in many cases are now baxren and highly saline-alkali. Genorally, however, the stream terraces are moderately to well drained at preant and appos to bo woll madapted to inrigation developuent. 
(3) Recent aymin along the several. streams is so subject to inundation, scouring and deposition during flood periods that very little has renained. long in cultavation. Some few areas are farmed along all the rivers, but the agrleulture 1s hazarcious, unpsedictable and generaliy of little permanent value. With the installation of reservolrs, diver'sions, and new canals, and with extensive control works, some of these lands may be brought into use. For the most part they are loamy fine sands to loems, uniform to stratifled profiles. The surface is very Irregular, numerous old strean channels meander throughout the areas, wind eroston has left much of the land in badly burnocked condition. Scouring and redeposition has resulted in frequent grevel and sand bars. These areas for the most part, are covered with farru grass and salt cedar. Some bermda oceurs in smooth sites: maxshy areas support cattai2.s, rushes, plume grass and giant reed veldt grass, and some willows. The land has water tables varying from a few inches to $3-\mathrm{m}_{4}$ meters below the surface. Salinity is generaljy high,

In the lower Darweshan, the Garnsel and Chakansur areas, berren shifting sand dunes are moving across these lands ontc the strean termaces or upon to the generaliy high desert plains. In these areas reclanstion of recent alluvial solls would be a most discouraging task. In the upper Helmand and Arghancab drainage and leveling can be Palry successful on the loamy fine sands to sandy loans. The danger of $100 d$ damage to structures is everopresent, however.

\section{i. Principel Physteal Properties of S. W. Afghanistan So11s}

\section{(1) Permeability}

Since permeability affects Irrigation design, farm irrigation efficiency, percolation losses and drainage, it has been mapred in the fleld survey and determined by $\mathrm{lab}$ and field measurements.

Table 36 sumexizes the fleld infiltration tests made during the surveys. They were made with double rings, $22^{\prime \prime}$ outer and $15^{n}$ inner, set several inches into the solls. Water was maintained at about the same level in the two rings and the rates determined on the basis of the imer ring. The wetted soil pattern was determined by excavating after allowing $2-3$ days for the moisture to nearly reach equilibrium. In filtration rates were measured also during leaching trlals of basins and in irrigation efficiency measurements. Init1al intake rates ranged from as low as 0.5 inches per hour on 2 strongly saline-a.2kall sllty clay to as high as 4.07 inches per hour on a coerse sandy loam. Final inflitration rates af'ter solls had been saturated for $10 \mathrm{~m}$ 100 hours ran from as low as 0.02 inches per hour on a highly saline alkall. sility elay to as high as 1.5 inches per hour on a sandy loam. No loany sands or sands were Included in these tralals, but a loose very gravelly soll rax 20 inches per hour. The duration of the tests varled from 10 -200 hours depending on the soll.

Table 37 sunmariges the rates by soil textures and subdivides these into surface and subsoils. The effect of high exchangeable sodium with or without gypsun was studied as a clve to reclaimability. The solls with high exchangeable sodiun and low gypsun content had signiflcanty lower IInal Intake rates than normal solis. This is characteristlcally common In subsol.2s because of the tendency for the clays to der flocculate and "jell" or seal of the normal soil pores transmitting water. However, only the silty cleys dropped below 0.10 inches per hour, which is consicered as pow tentially reclatmbio. Those soils contalning moderato to high anounts of gypevin renained perneabie. The normal besic rates for the general textural groups are anty 


\begin{tabular}{|c|c|c|c|c|c|c|c|}
\hline \multirow{3}{*}{$\begin{array}{l}\text { Name of } \\
\text { Pro ject } \\
\text { Ares }\end{array}$} & \multirow[b]{3}{*}{ Location } & & \multicolumn{3}{|c|}{ - Infiltration Data } & \multirow{2}{*}{\multicolumn{2}{|c|}{$\begin{array}{c}\text { Averege of } \\
\text { Texture }\end{array}$}} \\
\hline & & & Initial & FInal & Hours & & \\
\hline & & $\begin{array}{l}\text { Soll } \\
\text { Sxmbol }\end{array}$ & $\begin{array}{l}\text { Rate } \\
\text { in./hro }\end{array}$ & Rate & Test & $\frac{\text { Repres }}{\text { Top Soli }}$ & $\frac{\text { sented }}{\text { sub-soi }}$ \\
\hline Tarnak 1956 & Shamshier Area & $(1 M 33)$ & $\frac{210 / 010}{2.25}$ & $\frac{1.10200}{0.20}$ & $\frac{468}{45}$ & S1 io & S1.C.LA \\
\hline no/gyp. & Photo $24=3711$ & IH12-PS5 & .50 & 0.06 & 40 & Sico. & S1.C. \\
\hline wop. & $n \quad n$ & " & .70 & 0.10 & 44 & " & \# \\
\hline no/gyp. & $n$ & $1 M 32-P S 5$ & .90 & 0.25 & 30 & Si.L。 & S1.Joor Lo \\
\hline w/gypo & ๓ & is & 1.15 & 0.30 & 30 & " & $n \oplus n$ \\
\hline no/gyoo & $n$ & 2Hב2 PS5 & 0.60 & 0.05 & 43 & Si.C. & Si.c.or co \\
\hline$w / \mathrm{ggp}_{\mathrm{p}}$ & n & n & 0.70 & 0.04 & 110 & $n$ & $\pi n$ \\
\hline no/gypo & m & $1 M 22=P S 5$ & 0.90 & 0.15 & 45 & S1.L。 & S1.C.L. \\
\hline w/вyp。 & $n$ & ๓ & 0.60 & 0.20 & 37 & $n$ & $n n n$ \\
\hline $\begin{array}{l}\text { no/gypo } \\
\text { w/gypo }\end{array}$ & $25-3876$ & 11.33-PS5 & $\begin{array}{l}0.95 \\
0.75\end{array}$ & $\begin{array}{l}0.15 \\
0.18\end{array}$ & $\begin{array}{l}32 \\
27\end{array}$ & L.S. $_{n}$ & $L_{n} \operatorname{Lor}_{n} \mathrm{~S}_{n} \mathrm{Cod}_{n}$ \\
\hline no/gypo & n & 1M23-PS5 & 0.95 & 0.19 & 32 & S1.L. 0 & Si.C.L。 \\
\hline$"$ & $n$ & ${ }^{n}$ M3 $-P S 5$ & $\begin{array}{l}0.95 \\
1.20\end{array}$ & 0.12 & 57 & $n$ & n " n \\
\hline$w / g y p$ & " & 10. & 0.85 & $\begin{array}{l}0.13 \\
0.20\end{array}$ & $\begin{array}{l}46 \\
32\end{array}$ & $n n$ & N1.0. \\
\hline no/gyp。 & $25-3930$ & MM23-PS5 & 1.15 & 0.18 & 29 & $n n$ & Si.Cl.I. \\
\hline$n$ & n & " & 0.90 & 0.18 & 50 & $n n$ & $n N$ \\
\hline$n$ & $n$ & n & 0.60 & 0.08 & 85 & $n n$ & $n n n$ \\
\hline$n$ & n & $n$ & 0.60 & 0.06 & 138 & $n n$ & $n \quad n$ \\
\hline$n$ & $26=4,001$ & 1M34-PS5 & 1.50 & 0.04 & 80 & $n n$ & Si.L. \\
\hline w/gypo & n & $n$ & 2.00 & 0.04 & 80 & $n n$ & $n$ \\
\hline no/gypo & $n$ & 1H22PS5 & 2.00 & 0.05 & 80 & S1.C.or SCL & Si.co \\
\hline no/gyp. & $26-4002$ & 1 H23XPS5 & 1.5 & 0.05 & 120 & S1.C. & Si.C.L。 \\
\hline $\begin{array}{l}\text { w/grpo } \\
\text { no/grpo }\end{array}$ & $26-4003$ & $\stackrel{n}{1 H 12 \mathrm{PS} 5}$ & $\begin{array}{l}1.5 \\
2.0\end{array}$ & $\begin{array}{l}0.06 \\
0.05\end{array}$ & $\begin{array}{l}120 \\
140\end{array}$ & $\begin{array}{ll}n & n \\
n & n\end{array}$ & si. \\
\hline 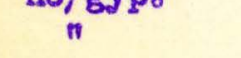 & $26-4004$ & 1M23PS5 & 2.0 & 0.10 & 85 & Si.L & Si.C.L。 \\
\hline$n$ & $n$ & $1122 P 55$ & 0.75 & 0.04 & 140 & Si.C. & $\mathrm{Si} . \mathrm{C}_{0}$ \\
\hline$n$ & $26-4069$ & 1H22PS5 & 1.90 & 0.03 & 145 & " $"$ & $n \quad n$ \\
\hline w/gyo. & & n & 1.50 & $n \times 2$ & 200 & $n n$ & $n n$ \\
\hline no/gyp。 & $26-4,125$ & IM33PS5 & 1.30 & 0.05 & 140 & S2. 1.0 & S1.L。 \\
\hline syp. & H & $n$ & 1.70 & 0.06 & 140 & " n & n $n$ \\
\hline no/gyp. & $n$ & 1M23PS5 & 1.25 & 0.12 & 60 & $n \quad n$ & Si.C.L。 \\
\hline $\mathrm{w} / \mathrm{ggp}$. & " & 甲 & 1.50 & 0.12 & 60 & $n n$ & $n \quad n$ \\
\hline no/gypo & $26-4127$ & 1H22PS5 & 1.50 & 0.02 & 250 & Si.C. & SioC。 \\
\hline & " & 1M33PS5 & 1.70 & 0.20 & 100 & S1.L。 & S1.I.0 \\
\hline$w / g y D_{0}$ & $23-27$ & n & 2.25 & 0.35 & 75 & $n n$ & $n \quad n$ \\
\hline
\end{tabular}

Note: Above tests were run on barren severely saline-alkali land with no land preparation. The amount of active gypsum was not properly computed and the amount added was far below gypsum requirements. All tests were made with double rings replicated $3-4$ times Tarnak 1953

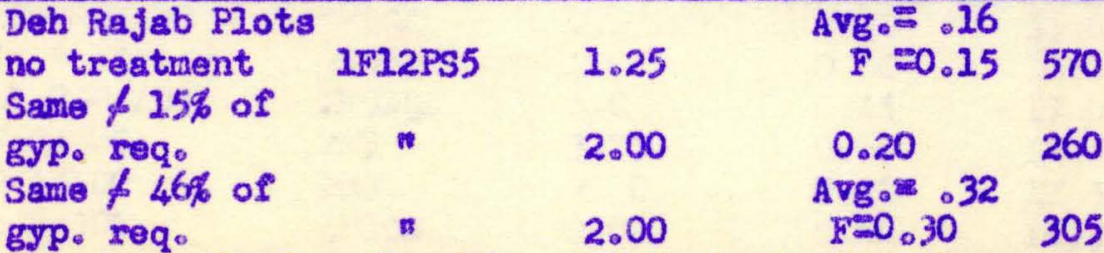

The above is from leaching trials in bosins plots replicated 4 times in both basins and double rings. 


\section{$8.5-$}

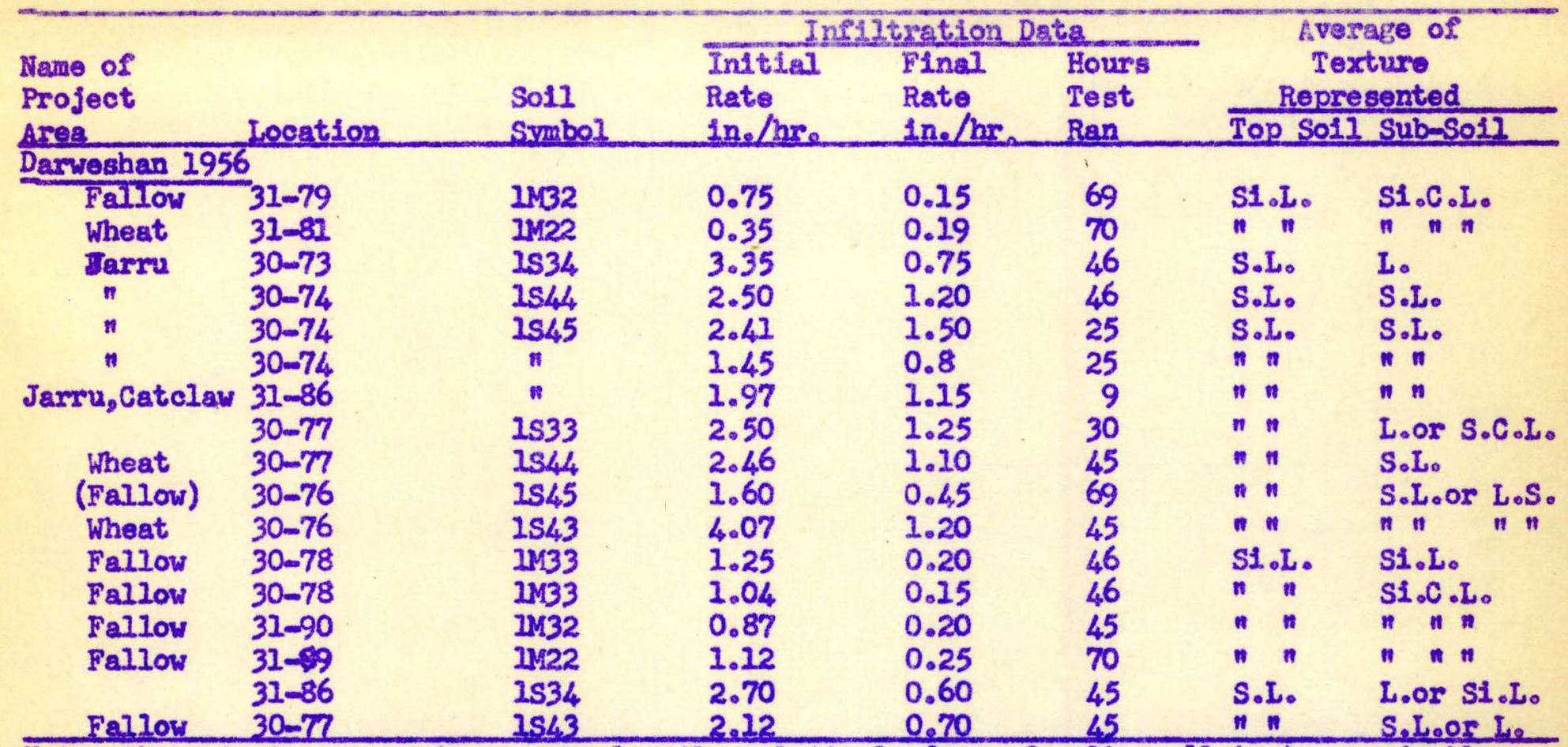

Note: These tests were made on noxmal soils relatively free of salts, all tests are double rings replicated \& times

Seraj 1956

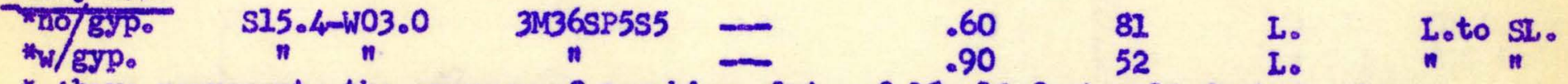

* Above represents the average of leaching plots of 18,12 foot $x 12$ foot, issins.
HI. Photo $32-98$ 2M2s
0.85
$.40 \quad 120$
Si.L. Si.C.L.

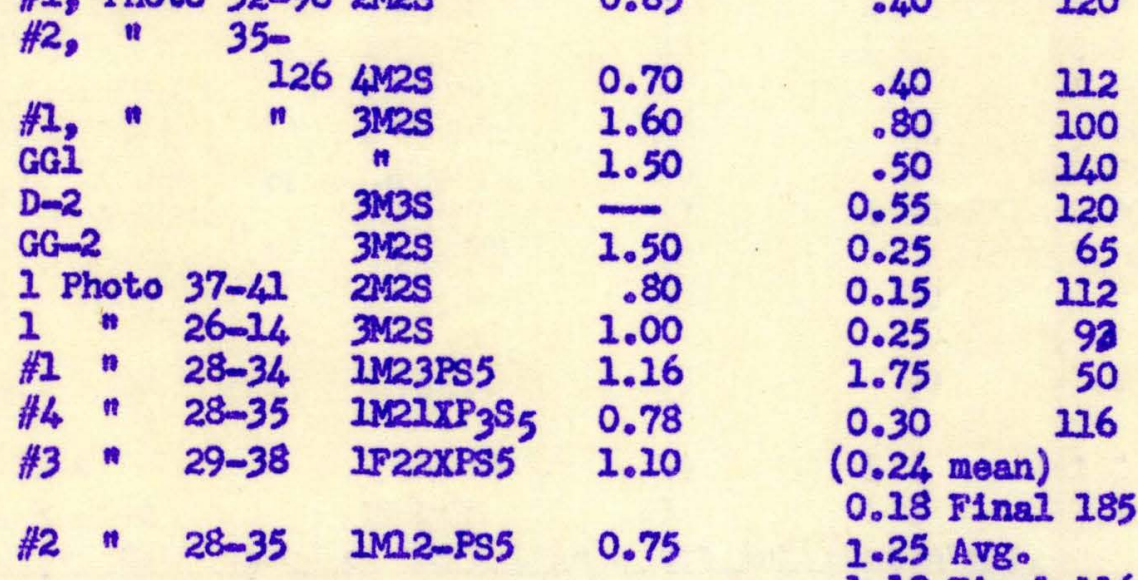

1.10 Final 116.5

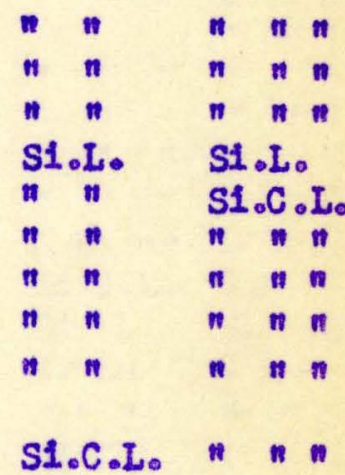

Si.t.

Si.c.l.

Note: All except first two are double-ring infiltrometer tests with 3-5 replications. Lab. data avallable on leaching treials and on last 4 infil trometer teats.

\begin{tabular}{|c|c|c|c|c|c|c|c|c|c|c|}
\hline 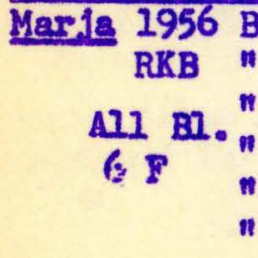 & 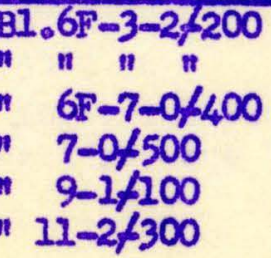 & $\begin{array}{l}5 M 3 Q Z \\
3 M 53 Q 2 \\
2 M 34 Q Z \\
2 M 3 \\
2 M 3 \\
4 M 3 Q Z\end{array}$ & $\begin{array}{l}2.4 \\
2.0 \\
4.0 \\
3.75 \\
2.00 \\
2.00\end{array}$ & $\begin{array}{l}0.99 \\
0.60 \\
0.45 \\
0.60 \\
0.40 \\
0.60\end{array}$ & $\begin{array}{l}15.0 \\
16.0 \\
17.0 \\
17.5 \\
17.5 \\
16.5\end{array}$ & 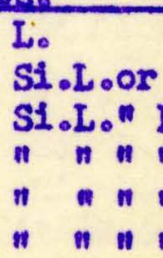 & $\begin{array}{l}I \\
L \\
\text { L. } \\
n \\
n \\
n\end{array}$ & $\begin{array}{l}\text { Loor } \\
\text { Soc } \\
\text { S1. } \\
n \\
n\end{array}$ & $\begin{array}{l}\text { S.L. } \\
\text { or L. } \\
\text { L. or } \\
n \\
n \\
n\end{array}$ & $\begin{array}{l}\text { I. } \\
\text { in } \\
n\end{array}$ \\
\hline
\end{tabular}


Nime of

Project

Area

Marja 1956

RKB

$1952 \quad 546-452$

$536 \times 1544$

$540-W 52$

$540=154$
CPS

Infiltration Data

Intia Fins? Hours

Rake

Sol1

Symbol

B1.6/13-1/800

- 13-24500

" $19-24500$

" $19-3,-200$

Test
$2 g S 3$

$2 \mathrm{M} 56$

$2 \mathrm{N3}$

$5 S 5 Q Z$

2543

21443

3550783

$4 \mathrm{ML2OZ}$

2Mk in. $/ \mathrm{hr}$.

4.00

2.50

2.40

5.00

3.20

2.2

2.7

2.2

1.35

1.05
Rato

In./hro Ran

0.50

0.60

0.40

1.80

0.90

1.0

1.9

1.25

0.27

0.70

22.0

20.
Average of

Texture

Represanted

Top So11 Sub-So11

S.I.

17.5

17.0

12.0

25.0

24.0

22.0
L

SiLorL SILorSCL

S.I. SLorLS

S.L. S.L.

Silorl S.L.orsCL

$S$ Sor L.S.

Lor S1.I SLor SCL

" " " " "

Note: 1952 tests are averages of 2 replications, 1956 tests are averages of 3 replications. Both are made with double rings.

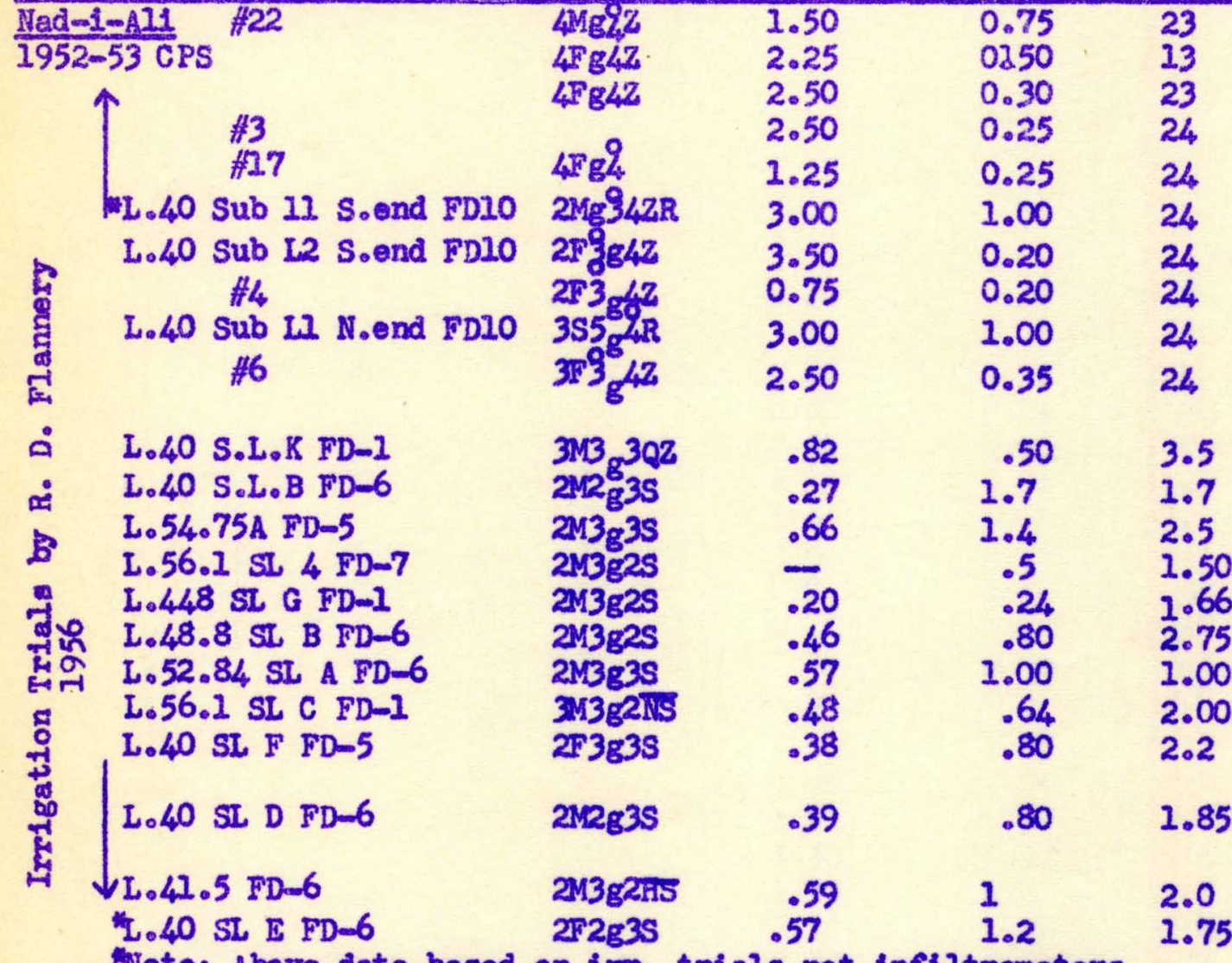

Note: Above data based on ir. trials not infiltrometers.

Chiseled 80uscre Dr. Plots 2M3425

-1.7
$-\quad 0.9$

Disced

"

0.9

$-$

1952

N. Arghandab

1953 E57\$750-S-36

$\frac{\text { IM32 }}{\mathrm{A}_{\mathrm{x}}} \mathrm{PS}_{5}$ wo/Eyp. .09

$-$

(Leaching trial-Mishowar)

S.Canal Barrel seepage tests " 1956

"

C.Argh。 Plot 1 Photo $16-58$

$w / g y p$.

"Compacted Silts"

Loose

$n$

.20

0.12

Gravelly soils

1956

16-57

IM32 PS5

0.85

3.60

20.3

IM23PS5

1.10

0.15

0.55

190

$\left(2.5^{n}-62.5^{n}\right.$ range)

Si.L. Si.C.L。

n $n$

Sil or I L or SCL

SIC.L.CL " $"$ "

$n$ * $n$ ท $n$

* $n$ แ $n$ n

Sil or L GroLorsil.

SICL MLL SL or CL

" $"$ "

S.I. S.L.

SiC.L。 Si.L。 or or C.L. S.C.L.

I.Or SII I or SII

" " SCL or CL

" $"$ I to C.L.

$n$ ก $n$

n $n$ " $n$ n

$n n \mid n$ " $n$

" $n$ n $n$ n

C.I. or I to

S1.C.I. C.L.

Si. I. SI C.I. to

or L. CoL。

n $n$ n $n$

Si.C.L.

or C.L. " "

I to SIL I to SCL

" " " " 
TABLE 37

FIELD STUDTES OF WATER INTAKE RATES OF S. W. AFGHANTSTAN SOTIS

\begin{tabular}{|c|c|c|c|c|c|c|c|}
\hline \multirow{3}{*}{$\begin{array}{l}\text { Group } \\
\text { (Textural) }\end{array}$} & \multirow{3}{*}{$\begin{array}{l}\text { Textures } \\
\text { Included }\end{array}$} & \multicolumn{2}{|c|}{ Normel soils I/ } & \multicolumn{4}{|c|}{ High Sodium Solls $2 /$} \\
\hline & & \multirow{2}{*}{ Mean } & \multirow{2}{*}{$\begin{array}{l}\text { Moan } \\
\text { Final 6f }\end{array}$} & \multicolumn{2}{|c|}{ With Grosum 3/ } & \multicolumn{2}{|c|}{ Without Giposum $4 /$} \\
\hline & & & & Mean Initial & Mean Final & Mean Initial & Mean Fin。 \\
\hline $\begin{array}{l}\text { Mod. } \\
\text { Coarse } \\
\text { rextured IJ } \\
(36)\end{array}$ & $\begin{array}{l}\text { Loany Sands } \\
\text { to } \\
\text { Sandy Loams }\end{array}$ & $\begin{array}{l}\text { Morso }=2.45 \\
\text { Max。 }_{0}=4.65 \\
\text { Min。 }_{0}=2.30\end{array}$ & $\begin{array}{l}\text { Norm=1.00 } \\
\text { Max. }=1.84 \\
\text { Min. }=0.58\end{array}$ & No & 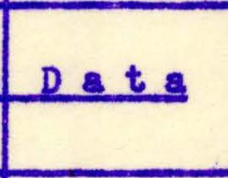 & & \\
\hline $\begin{array}{l}\text { Yed. } \\
\text { reartured } \\
\text { Solls } \\
(144)\end{array}$ & $\begin{array}{l}\text { Loams, } \\
\text { Sandy clay } \\
\text { loams, } \\
\text { Silt Loams }\end{array}$ & $\begin{array}{l}\text { Morm=2.15 } \\
\text { Max. }=3.65 \\
\text { Min. }=0.95\end{array}$ & $\begin{array}{l}\text { Norm }=0.45 \\
\operatorname{Max}_{0}=1.50 \\
\operatorname{MLn}_{0}=0.25\end{array}$ & $\begin{array}{l}\text { Norm=2.15 } \\
\text { Max, }=2.25 \\
\text { Min, }=0.60\end{array}$ & $\begin{array}{l}\text { Norm }=0.30 \\
\operatorname{Max}_{0}=1.75 \\
\operatorname{Min}_{0}=0.04\end{array}$ & $\begin{array}{l}\text { Norm }=1.00 \\
M a x_{0}=2.50 \\
\operatorname{Min}_{0}=0.60\end{array}$ & $\begin{array}{l}\text { Norm }=0.25 \\
\text { Max. }=0.25 \\
\text { Min。 }=0.04\end{array}$ \\
\hline $\begin{array}{l}\text { Mod. } \\
\text { Heavy- } \\
\text { rextured } \\
(62)\end{array}$ & $\begin{array}{l}\text { Clay losms, } \\
\text { SIlty Clay } \\
\text { loams }\end{array}$ & $\begin{array}{l}\text { Norma } 1.55 \\
\operatorname{Max} .=3.25 \\
\operatorname{Min} .00 .60\end{array}$ & $\begin{array}{l}\text { Mory }=0.28 \\
\text { Max。 }=0.65 \\
\text { Min。=0.18 }\end{array}$ & $\begin{array}{l}\text { Norm=1.15 } \\
\text { Max, }=2.00 \\
\text { Min。=0.60 }\end{array}$ & $\begin{array}{l}\text { Norm }=0.20 \\
\operatorname{Max}_{0}=0.55 \\
\operatorname{Min}_{0}=0.06\end{array}$ & $\begin{array}{l}\text { Norm }=1.00 \\
M a x \cdot=2.00 \\
M i n_{0}=0.60\end{array}$ & $\begin{array}{l}\text { Norm }=0.10 \\
\text { Max }_{0}=0.19 \\
\text { Min. }=0.05\end{array}$ \\
\hline $\begin{array}{l}\text { Heavy } \\
\text { rextured } \\
\text { Soils } \\
\text { (24) }\end{array}$ & $\begin{array}{l}\text { Silty C1ays } \\
\text { to } \\
\text { clays }\end{array}$ & No & - & $\begin{array}{l}\text { Norm }=0.75 \\
\operatorname{Mex}_{0}=1.50 \\
\operatorname{Miln}_{0}=0.70\end{array}$ & $\begin{array}{l}\text { Norm }=0.06 \\
\text { Mex. }=0.20 \\
\text { Min. }=0.03\end{array}$ & $\begin{array}{l}\text { Norm=1.50 } \\
\text { Max. }=2.00 \\
\text { Min。=0.50 }\end{array}$ & 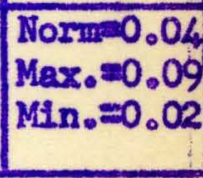 \\
\hline
\end{tabular}

Footnotes: Data is taken from double-ring infiltration tests, besin leaching trials and irrigation trials.

1 Normal soils containing generelly less than $15 \%$ exchangeable sodium。

$2 /$ Contalning more than $15 \%$ exchangeable sodium.

3/ Gypsum added or present in fair to high quantities.

Lf Generally no gypsum added - may or may not be present in soll.

5/ Rate during first few minutes to one hour.

6) Stsady rate achieved after several hours run.

If Numbers in parentheses indicate the mumber of tests or combinations of tests used in computing the values given in the table. 


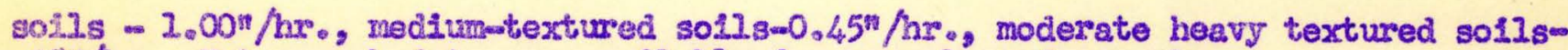
$.281 / \mathrm{hr}$. Not enough data was avajlable for normal sands or clays.

Parmeability is determined in the solis laboratory as a regular procedure using the prepexed samples under constant head as described in V.S.D. A. Handbook No. 60. Draving. .D 121, sumarizes the finol or basic pormesbility as determined by this nethod. Compared with this technique the field estinated permeability, shown in dsshed lines, gives higher values for light-textured and lower values for hesvy textured solls.

\section{(2) Saturation Porcentages and yotor-holding Capacits}

Ability of the soil to retain water for plant use is highly important in imigation farming. The total readily avallable nolsture that a soll will release before any section of the root zone of a growing crop begins to suffer determines the fraguency of irrwigation and the irrtgation design necessary. Severel thousand isoli samples have been analyzed. The surmary of these with respect to saturation parcentage, textural. grade and available molsture in inches por foot is given in Dreving ID 115. For conventence the fleld permeability index as ostimated from Field examination of soils is glven. From these relationshlps and soil dopths and volume weighis, the total readily avallable molsture at field capacity has been computed for 0.11 solis mapped. Values ranged from less than 1.0n for very shallow, vory grevelly or extremely coarse sendy sol.1. to over 9.0" for very deop, medlum to moderately heavy-textured solis. All soils with less than $1.5^{\prime \prime}$ of readily available nolsture espacity wore classed as non-irrigable.

c. Associated or Site Factors affecting Use, Present and Potential Use Capa-

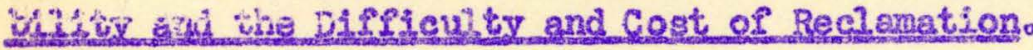

Site factors refer to those conditlons that are not necessarily a soll property but modify the behaviour of the sol2 or the particular soll site. These face tors include solinity and alkalinity, grourd water tables, topography, flood or eroston conditions and hazards, and presence of 100 se stones and cobble. Tamporary or removable conditions, such as a hunmociry condition renovable by leveling, or loose stones or walts which ray be renoved by leaching, are considered as "teinorary limi-tationg" and af hand flood hazards, or the constant threat of erosion, or a recurrent salinity condi-n tion caused by a non-iemovable high water table would require not only immediate ato tention but consistent and careful application of one or more special practices or nossures to control thase conditions. Such site factors do limit the potential use capsbility of the land and are so considered. The varlous site factors considered and their extent are discussed below。

\section{(1) Leveing}

ESflelent use of water Lnvolves spreading it evenly over the land to be irrigated. This means more uniform erop growth and yields. High spots dry up beSore other parts of the fleld noed water. If the solls have a teadency toward temporary, perched water tablos, these high spots are focal points for salts to accurnulate. These in turn create greater moligture stress and plants suffer for molsture even though the soil may have more than a nonoseline spot nearby. Low spots receive too mach water, the plants suffers for lack of aeration, the soils puddle and bake, and poor growth results. 
All fields need annual levallng and moothlng for best results. Because this

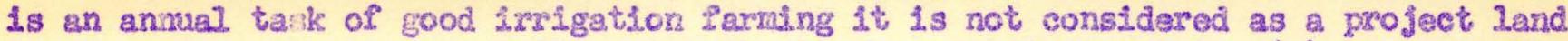
developnent tas: In the soll survey the lands wore divided into, (a) those having relatively smoo h slopes so that the farmer could do most of the work oxcept for general planing and moothing for the initial 1rregation layout, (b) those areas requiring 1ight to moderate cuts and 1111s, (c) those areas requiring heavy cuts and f1.1s and Iikel to be costly to develop, and (d) those considered too rough for practical development.

The survey shows that most of the avallable lands aro relatively mooth and generally of lo.ig slopes ranglng from .0005 to .005 in grade, the nore common belng $.001-002$. Ext onsive areas along the Helmand Velley are bumocky, and covered with salt ceder or tough grasses (jarru). These wlil require extensive elearlng, heavy

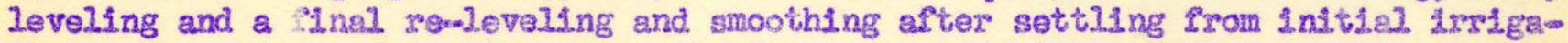
tion. The exte at of leveling and relative costs have been studied by ACU. Leveling needs of the ve:Lons project areas are sunnarizad In Table 38.

\section{(2) Soreading and Deep Plowing Sands}

In so ne areas such as the Marja, the Daxweshan, Carnsel and Chakansur Irclamation and control of lands w111 requite the spreading of sand drifts and incorporating the se sends Into the soll by deep plorlng. This job requixes casetul. surveys and suyervision by solls expexts during the actual oparations. The correct depth of plowing mat be determined by study of the coarseness of the sands and tho textures and thleknesses of underlyling soli horlzons. Otheruise costly plowing and re-leveling may be wasted effort.

\section{(3) Brush cloaring and Grubbing}

Hummock valley soils are covered by salt cedar (tamarix gallica, to Indica, t. sallna) which has tough, deep roots and a heavy crown Claaring is geaerally by weans of a brush cutter with a bar on the front of a renodeled geraper which undercuts the heavy roots and brings them to the surface. This helps accompliah rough leveling as it knocks down and pertially spreads the sands and silts piled about tho brush. Jarru grass areas noed deep, coublemdiscing with serrated dises to tear up the stubborn root crowns which make leveling difflcult. The extent of brush cleratw ling is shown in Table 38 .

\section{(4) Drainage}

The most exticel and yet the most neglected phase of Irregation agreculture In Afghanistan is that of drainage. Through long centuries of petlence, to11 and experience the Afghans have learned Ingenous mothods of carnylng water to the land. The karez as a water systen 1s known only in this pazt of the globe. Despite the Innumerable ovidences of 1 rrigation not one drain can be found except a very few recent ones of crude and jinadequate desLgn.

As discussed abovs the desert plains solls are generally in need of drainago. Some of these lands have such shallow depths to bedrock or tightly compacted clays, adequate drainage vili almost be lmpossible. The valley 1111 and terrace benches are somewhat better situated in that the solis are usually deop and drainable materials occur from 204 meters below the surface. In many places the aculfors aro slow or strat1fied, however. Ground water is now 2 - meters below the surface in. most of these areas. Additional wastage of irrigation water through over 1 mrigailon or leaching will add to the water table and cause it to rise to dengerous levels un. less drainsge is provided. 
"Table 32, will be forwarded later. The Vexious sources of date from field in= restigations cannot be compiled in time for this roport. As goon es the drain= age investigations are far enough along and the data is compilled. Table 39. will be computeden 
The effects of these various influences have been the salination of extensive areas and abandoment of laxge tracts of formerly irrigated lands bacauss of high salinityo

(6) Alkalinity

Where the salts thus deposited are high in sodiun salts in relation to to calcium and magneslum salts which remain soluble through wetting and drying, the clay fraction of the soll absorbs godium lons in exchange for calcium and megriesium jons. This sets up a condition which may be unfavorabie for plant growth and may make reclangtion somewhet more difficult. In some casea where the soluble salts gradurily leach out of the upper 18yess of 3011 the clays high in exchangeable sodiun may disperse, 1030 structure and become susponded or move downward with the gravitational Slow of water, and thus seal up the nsturel solil pores. In extreme cases the solis may be alnost Lnporvious. Numerous 1ab. and fleld lexching trials have boen caryied on to determine the extent of this condition in Afghanistan solis. A summation of lab. studies is given in Table 40. It will be noted that only a sunall porcent (1.4\% $-5.4 \%$ deponding on range used) of the soils are now "alkali" solis or in a pooz physleal and chemical condition for present use or reclamation. "Saline-alkali" soils are the nost common (32.8\%m/2.1\%)。 In these solis a high percentage of soluble salts including soluble calcium salts are found in association with high exchangeable sodium. Extensive tests have show that the exchangeable sodlum decreases on leaching at a somewhat slower rate than the soluble salts but nevertheless does nove out. The soll pormeability has rem mained sufilclently high, except in the heavy to silty clay and clay solls, to permit cont1mued leaching. Most of the solls contain varying anounts of natural. crygtalline gypsun as well as large quantities of calcuun carbonate. The presence of gypsum improves the permeability of soll and elso decreases the exchangeable sodium at. higher rates. Such soils have given little difeiculty in leaching trials. The addition of gypsum to leaching plots has been effective in the heavier solls of low initial gypsun content but has not made much difference on other salinom alkali soll conditions. It appears that given reasonable dreinage nost of these solls can be reclaimed for use. In the interegt of project development, however, the majority of the highly saline-alkali solis have been rejected and only about $1 / 5$ deferred for Iuture reclanation. (See Table 4 ). These areas lie over more perneeble substrata and are commonly solis of modorately 2 ight to medium texture and fals to very good permeability. Chapter $V$, Section 3, d1scusses in detail the necessery steps involved in reciarcation of these solls.

\section{(7) Boron in So27s}

Boron may cause Injury to sowe plants when concentrations are above 3 pya and is toxic to most all plants at concentrations sbove $100 \mathrm{ppm}$. (Soe To,blo 49 . Chapter V, Section 3.) Analyses of a mmber of solls in the projects show boron present. About $7 \%$ of the samples anslyzed had boron in concentrations greater than $15 \mathrm{ppm}_{2} 25 \%$ between 5 and 15 pprin and $68 \%$ less than 5 ppr. Most comon field crops grown here are not seriousiy affected by concentrations below 5 ppom.

Leaching trials show boron salts move out more slowly than the other soluble salts but more rapidly than the rate exchangeable sodlun decrsases in a salinealkali soil. Whare l-2 acreafeet of leaching water per foot of soll ugueliy suifices for normal leaching, high boron soils may require 3 es acresfeet per foot and thus require louger to reclaim. (See Chapter V, Section 3 on treatment of high boron solls.). 
The following sunnary is based on the characteristic of meline and alkels solis ss

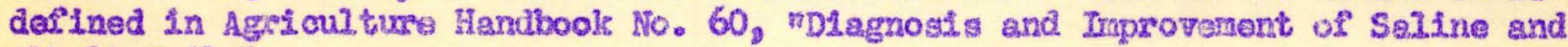
Alkal1 golis:

The seale of conductivity and E.Sop. has been adjusted to lnclude the ordinary ASghan field crops which have a higher rolative tolarance of salts:

$$
\begin{aligned}
& \text { Saturation Extract - Loss than } 10 \text { mi11imhos/em } \\
& \text { Non-Saline - p " } " \text { " " " } 8.5 \\
& \text { E.S.P. (Excho Na peto) Ioss than } 20 \% \\
& \text { Saline - Satusation Extract - Greater than } 10 \text { m111 Imhos/cra } \\
& \text { Fl" " } " \text { Loss then } 9.5 \\
& \text { LoSoP, II - Less than } 20 \%
\end{aligned}
$$

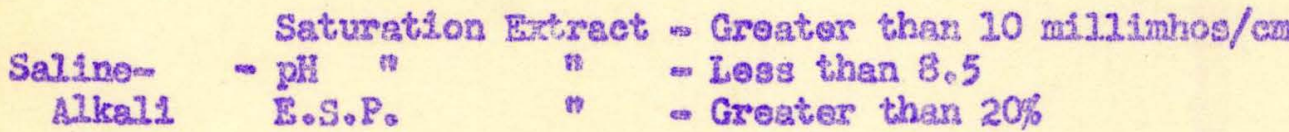

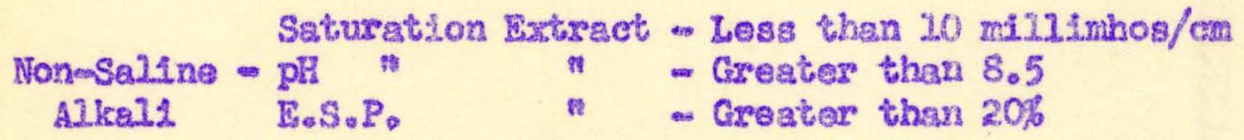

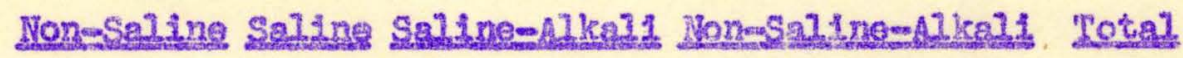

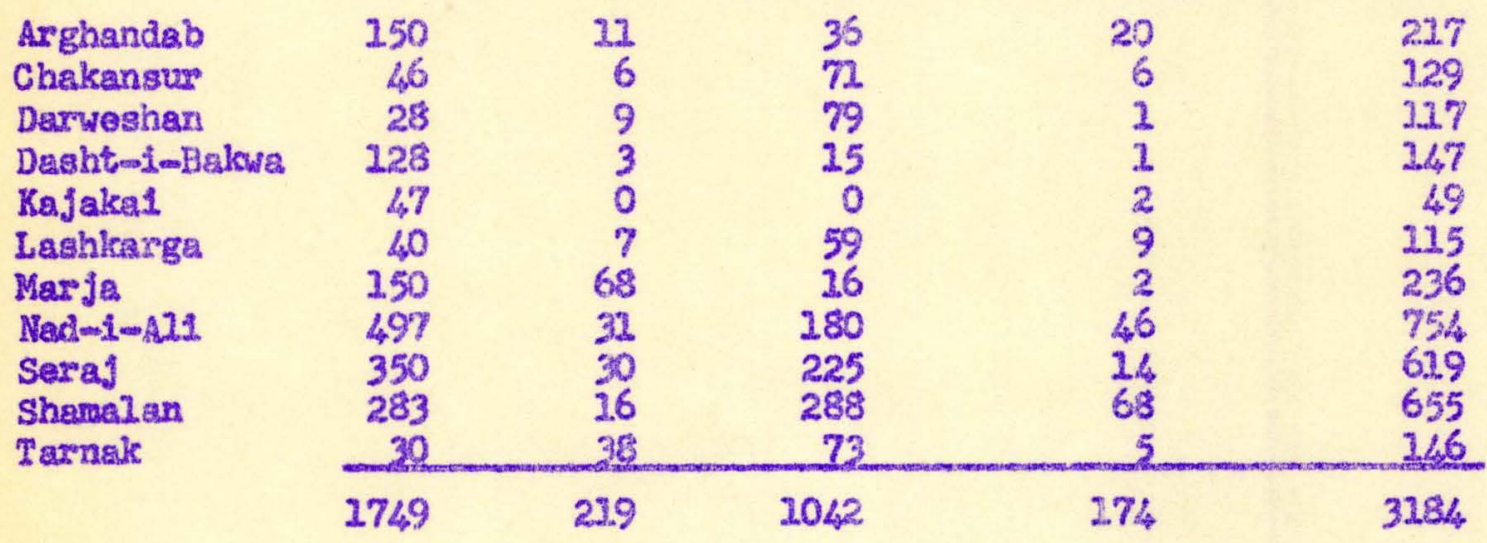

Percent of salinfty or alkalsinttg when scele of conductivity is edjugted to 10 mil.1. mahos/cm and the E.S.P. to 20\%: Non-Saline

$$
\text { Saline }
$$

$55.0 \%$ of all axples

Saline-Alkals $6.8 \%$ Alkals

Percent of salinity or alkalinity when scale of conductivity is adjusted to 4 millitrabos/en and E.S.P. to 15\%:

Non-Saline

Saline

Salinomalkeal.

Alkals
$35.0 \%$ of all samples

$21.5 \%$

$42.1 \% "$ " "

$204 \% " 1$ 
March 5, 1957

Talbie 41 A STUDY OF THE RELATION OF SOIL SAIINITY AND ALKALINITY TO CLASSIFIC ATION OF SOILS MAPPEIJ IN HELMAND BASIN

\begin{tabular}{|c|c|c|c|c|c|c|c|}
\hline \multirow[b]{2}{*}{$\underline{\text { Ares }}$} & \multirow[b]{2}{*}{$\begin{array}{l}\text { Total } \\
\text { Surveyed } \\
\text { Area }\end{array}$} & \multirow{2}{*}{\multicolumn{2}{|c|}{\begin{tabular}{|l|l|}
\multicolumn{2}{|c|}{ Lands Irrigable Now } \\
To salninty & Srignt w \\
ox & moderate \\
alkalinfty & salinity \& \\
affecting & alkalinity \\
crops & crops do \\
& well \\
\end{tabular}}} & \multicolumn{2}{|c|}{$\begin{array}{l}\text { Landis Irrigablo After } \\
\text { feasible reclamation }\end{array}$} & \multicolumn{2}{|c|}{$\begin{array}{l}\text { Non-Irrigable } \\
\text { or not reconmended }\end{array}$} \\
\hline & & & & 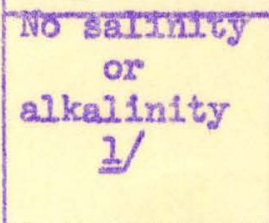 & $\begin{array}{l}\text { Sarninye } \\
\text { alkalinity } \\
\text { moderate } \\
\text { to severe }\end{array}$ & $\begin{array}{l}\text { Toline- } \\
\text { alkal1 } \\
3 /\end{array}$ & $\begin{array}{l}\text { por. co } \\
\text { Very } \\
\text { severe } \\
\text { saline- } \\
\text { alkali }\end{array}$ \\
\hline$\underset{1}{\text { Tarnak }} \underset{\%}{\infty}$ & $\begin{array}{c}110,656 \\
100\end{array}$ & $\begin{array}{r}23,270 \\
21.11\end{array}$ & $\begin{array}{r}36,507 \\
32.90\end{array}$ & 20 & $\begin{array}{c}20,1683 \\
9.19\end{array}$ & $\begin{array}{r}22,590 \\
20,42\end{array}$ & $\begin{array}{r}18,121 \\
16.38\end{array}$ \\
\hline${ }_{n}{ }^{\text {Darweshan Acres }}$ & $\begin{array}{l}73,910 \\
100\end{array}$ & $\begin{array}{l}32,060 \\
43.4\end{array}$ & $\begin{array}{c}10,708 \\
14.5\end{array}$ & $\begin{array}{c}2,243 \\
3.0\end{array}$ & $\begin{array}{l}4,320 \\
5.8\end{array}$ & $\begin{array}{c}17,237 \\
23.4\end{array}$ & $\begin{array}{c}7,342 \\
9.9\end{array}$ \\
\hline N. Arghandsb Acres & $\begin{array}{l}67,685 \\
100\end{array}$ & $\begin{array}{l}28,425 \\
42.0\end{array}$ & $\begin{array}{l}7,018 \\
10.4\end{array}$ & $\begin{array}{l}689 \\
1.0\end{array}$ & $\begin{array}{l}7,602 \\
13.2\end{array}$ & $\begin{array}{c}17,730 \\
26.2\end{array}$ & $\begin{array}{l}6,221 \\
9.2\end{array}$ \\
\hline C. Arghandab Acros & $\begin{array}{c}132,220 \\
100\end{array}$ & $\begin{array}{l}48,607 \\
36.7\end{array}$ & $\begin{array}{l}29,478 \\
22.3\end{array}$ & $-\infty$ & $\begin{array}{l}9.340 \\
7.0\end{array}$ & $\begin{array}{c}26,400 \\
20.0\end{array}$ & $\begin{array}{c}28,395 \\
14.0\end{array}$ \\
\hline${ }_{n}^{\mathrm{Nad}-I-\alpha 21}{ }_{\%}$ Acres & $\begin{array}{l}25,000 \\
100\end{array}$ & $\begin{array}{l}21,366 \\
45.5\end{array}$ & $\begin{array}{l}3,594 \\
14,4\end{array}$ & $-\infty-\infty$ & $\begin{array}{l}5,664 \\
22.7\end{array}$ & $\begin{array}{c}1,553 \\
6.2\end{array}$ & $\begin{array}{l}2.8234 \\
11.3\end{array}$ \\
\hline$\underset{\pi}{\operatorname{Maxja}} \underset{\&}{A}$ & $\begin{array}{l}49,902 \\
100\end{array}$ & $\begin{array}{c}15,120 \\
30.2\end{array}$ & $\begin{array}{l}3,502 \\
7.0\end{array}$ & $\frac{1,881}{3.8}$ & $\begin{array}{l}9,166 \\
18.4\end{array}$ & $\begin{array}{c}10,225 \\
20.5\end{array}$ & $\begin{array}{c}10,552 \\
21.2\end{array}$ \\
\hline $\begin{array}{l}\text { Shamalan Acres } \\
"{ }_{\%}\end{array}$ & $\begin{array}{l}65,000 \\
100\end{array}$ & $\begin{array}{c}23,352 \\
35.9\end{array}$ & $\begin{array}{l}10,375 \\
16.0\end{array}$ & $-\infty$ & $\begin{array}{l}10,645 \\
16.4\end{array}$ & $\begin{array}{c}(5.000) \\
7.7\end{array}$ & {$\left[\begin{array}{l}15,628 \\
24.0\end{array}\right.$} \\
\hline${ }_{n}^{\text {Sere.j Acres }}$ & $\begin{array}{l}105,908 \\
100\end{array}$ & $\begin{array}{c}32,063 \\
30.3\end{array}$ & $\begin{array}{l}24,937 \\
23.4\end{array}$ & $\begin{array}{c}1,01.5 \\
0.9\end{array}$ & $\begin{array}{l}7.229 \\
6.8\end{array}$ & $\begin{array}{c}28,042 \\
26.5\end{array}$ & $\begin{array}{c}12,822 \\
12.1\end{array}$ \\
\hline $\begin{array}{l}\text { Lower He Imand } \\
\text { \& Chakansur Acres } \\
\text { " \& } \quad\end{array}$ & $\begin{array}{c}554,335 \\
100\end{array}$ & $\begin{array}{l}75.197 \\
13.6\end{array}$ & $\begin{array}{l}35,250 \\
6.4\end{array}$ & $\begin{array}{c}18,708 \\
3.4\end{array}$ & $\begin{array}{c}18,270 \\
3.3\end{array}$ & $\begin{array}{c}84,534 \\
15.2\end{array}$ & $\mid \begin{array}{c}324,376 \\
58.6\end{array}$ \\
\hline $\begin{array}{l}\text { Garmsel Acres } \\
11 \%\end{array}$ & $\begin{array}{c}154,827 \\
100\end{array}$ & $\begin{array}{c}3,829 \\
3.0\end{array}$ & $\begin{array}{c}13.529 \\
9.0\end{array}$ & $\begin{array}{l}217 \\
0.2\end{array}$ & $\begin{array}{l}38,175 \\
24.06\end{array}$ & $\begin{array}{c}13,298 \\
8.6\end{array}$ & $\begin{array}{l}84.314 \\
54.6\end{array}$ \\
\hline TORALS & $1,339,443$ & 293,289 & 174,698 & 24,756 & 120,579 & 226,609 & 500,594 \\
\hline$\%$ of total & 100 & 22.90 & 23.10 & 1.80 & 9.00 & 16.82 & 37.38 \\
\hline $\begin{array}{l}\text { \% of Irrigablo } \\
\& \text { Deferred }\end{array}$ & $(613,322)$ & 47.82 & 28.49 & 4.04 & 19.65 & $-\infty$ & - \\
\hline
\end{tabular}

1) Solls deferrod for leveling and drainage but having no seil ine-alkali problems.

$2 /$ This includes 9,065 acres of potential Classes I \& II \& 1,103 of potential Clasa III.

3/ Generally includes shallow, rocky or steep broken areas, sand dunes and gravel bars.

4 Areas in villiages included hero.

5/ Estimated proportion in sand dunes and gravel bars.

6/ Based on Chakansur Solls \& Drainage Survay Report showing the naxdmum useable land without major $1200 d$ and dralnage structures and erosion control. 
F. 0. Youngs in a report on the Helmand Valley Development Progrem, June 23, 1956, sald of the problems ahead, Many difficult problens confront those interested in developing the Helmand Valley into the productive and prosperous agricultural area it could and should be. It cannot be stressed too strongow Iy that at present success and failure are in the balance. Only a concerted effort on the part of all agencies dealing with the development, as well as farmers and land owners, will swing the balance in the direction of success. HVA, ACU, MKA and ICA should work in the closest harmony and should give as much aid as possible to the farmers in developing the land. Difficulties are of several kinds. Some of them are inherent in the character of the soil and the laymof-the-land. Others result from settling nomadic people with little or no knowledge of or experience in the complexities of irrigation farming and with meagre or no resources of money, equipment, seed or livestock" 。

Youngs devoted many years to agricultural problens of the southwest Asian deserts. With clearcut thinking he realized that the development of successful agriculture is the ultimate job of the farmer on the land. All the letterdesignated agencies can do in the long run is work in the closest harmony and ....... give as much aid as possible to the farmers....... Earlier in this report summaries of survejs and investigations are discussed which point up some of the jiysited. jobs to be done on the land. Problems of training equipping and guiding the farmers are beyond the scope of this report. That the eventual success of the development 1.s largely dependent on the human factor rather than soils or climate, is clearly recognized, however.

Among the physical land development problems all calling for skill, equipm ment and financing are land clearing and leveling, drainage, removal and control of salts and alkali, erosion and flood control and fertility management. Each project area has one or more of these tasks to do in the process of development. Some of the problems involved in each and the principles which may be used in their solution are briefly discussed here.

1. Land Clearing and Leveling. A sumary of project surveys, Table 38 , shows that 18,900 acres of land need clearing, 85,000 acres need 1 ight to moderate leveling, \& 8,000 aeres need heavy leveling. ACU estimated they would need to d1so 47,000 acres and land plano 118,400 acres In addition to the above tasks.

The acreage in each of the above categories is constantly changing because there are no means of keeplng abreast of what the farmers do for thamselves。 Irrelgation In the Shamalan has about doubled the annual acreage croppede None of this Increase was due to ACU, HVA or ICA efforts. Over the ent1re Arghandab Helmand systam it is estimated that 130,000 more acres of land are being farmed now than before development started. of this acreage $12_{8} 500$ in the Nad-i-Ali and about 6,000 in the Marja are direct results of the government's program.

The common brush to be cleared is salt cedar. A heavy cutter bar on a sultable fram is pulled beneath the surface deep enough to cut off the heavy roots and bring them to the suxface. Salt cedar will re-invade an area quickly, however。 Control of salt cedar as well as other plants will be a continuing job for the farner after the land is under irrigation. The salt cedar withes are woven into mattes and baskets, the tough stumps and roots are used for firewood. 
Considerable discussion has been given to the problem of leveling because of the costs involved. Actually, leveling equipment for finishing the farm ilelds into shape for efficient irrigation is lacking. Most of the leveling work done so far has accomplished only the major leveling into different levels or lands. The surface is left with quite irregular micromrelief that must be gmoothed and floated before water can be spread evenly. No attenpts have been made $e_{9}$ except on a for governnent tracts, to level to a finishod grade with 53 centimeters, tolerance.

The assumption has been that leveling need only be enough to provide water for Irrigating the smalf check basins so commonly used by Afghan farmers. Grading is done in planes with 8 $8 \mathrm{~cm}$. tolerance. It is expected that the farmer will eventually level and swooth the soll within each basin. Unfortunately, this is not always accomplished. Over irrigation of sone basins is a common practice while others recelve little water.

More attention needs to be paid to the depth and texture of solls in deterw mining safe cuts and fills. Much of the Nad-I-All and Marja Iand 1 s composed of relatively shallow solls. Cuts over $4^{n-6} 6^{n}$ may leave the remaining soll so thin it is not suitable for 1migation. In such areas swoothing and layout of smaller contour chegl basins may holp to get better distribution and with minimum leveling. Moderately'to deep soils of the desert plains soil (Seraj, Marja, Nad-i-Ali, Upper Tarnak, Upper N. Arghandab) w11l allow leveling for contour border or check border Irrigation. In all cases effort should be made to see that feeder ditches leading into borders or check basins can put the amount of water needed into each border or border-check in minimum time in order to decrease percolation losses. The deep and very deep river terrace and valley fill soils will ordinarily stand fairly heavy cuts. Generally grass or brush-covered land will be quite humnocky and heavy leveling will bo needed.

The type of irrigation layout best suited to an area will vary with the soll and general slope as well as the types of crops to be grown. No single set of rules will suffice for a large area. For guidance of design based on soil characeteristics, layout data is given in Chapter VII "Tillage and Water Use Practices" for the msjor soils.

2. Drainage. The extent of land areas affected by drainage was discussed in Chapter IV Section 3 . It was pointed out that this phase of land developaent is probably the most serious one in the Helmand Valley program. Same of the prinm ciples of dratnage as they affect erop production or briefly discussed here.

a. Plant tolerance to ground water - plants vary widely in growth reo quirements. Many common fleld crops and trees do best on deep, well-drained permeable solls which allow free root movement and permit air to the roots at considerable depths. Some plants have shallow root systems or may readily adapt a shallow root system permitting higher water table levels. Some plants will grow directly in water and have the ability to take up aj.r as needed from the water or through other paxts of the plant above weter. In rice culture, once the seedlings are established, the plants may stand in 3 "wn of water throughout the growth parfod. The problem of dralnage becomes, therefore, one of adjusting the factorg of drainobility and costs of drainage agalnst the expected beneflt? from crops adapted to different levels of dralnage. 


\section{bo TEMATIVE DEGREES OF DRA INABTLITI FOR USE IN CLASSIFYING \\ LANDS AS TO SUITABILTTY FOR IRRIGATION}

In order to assign a Use Capabllity Class to any parcel of land, Its rela tive drainsbility must be carefully determined and woighted along with other major characteristics such as so11, slope, erosion and climate。

The followlng degrees of drainability are so described ulth respect to limitations lmposed by these conditions that, otber fretox's not IImiting, they correlate with land use capability classes: L.o, very good F" and so on through the five degreas of drolnability doscribod.

The flve degrees of dralnability are described with respect to dopth to barriers or very alowly permeable layers, the permeability of the saturated or aquifer zone, the stratification of the soll and substratum, the depthy cono tinuity and character of aquifers, and the natural grades arailable for drains. Suggested limftations for drein depths and spacings are given for esch class or set of conditions.

Limitations of each factor have been compared with dralnage experfence and drainage recommandations in other areas. Ability of Afghan farmers to copo with drainage cannot be measured at this time. A few Iimited observations in dicate they can, where the cost of land and water is no factor, successfully apply thelr own labor to land of poor drainability, although major developo ment costs may not be economically justifled by a benefit? cost ratio based on construction costs by contractors and on Afghan market prices for production from the land. The physical ability of the land to meet the minimum use requirements of the land class aftar complete treatment is the primary criteria used. The economic justification of developing a parcel of land may vary wldely from locale to locale regardless of land class and can only be conputed where all cost, and production factors are known。

\section{di. -.. VERT COOD DRATNABILITY}

Barrierg wo barriers exist, or, if they do exiat, are found below 9 feet and are overlaid by very rapidly permeable aquifors permitting a freely drainIng solum of ovar $5^{\circ}$ in sandy or medium soils and $6^{\circ}$ in heavior solis, with up ward capllary movenent from the normal watertable broken by coarse materials。

Hydraulic Conductivity and Perperbility os The solls must have not less than $0.25^{\mathrm{m}} / \mathrm{hr}$-nor greater than $2.5^{\mathrm{m}} / \mathrm{hs}$ 。 permeability in the upper horizons and must be more open dowmerds so that, oven with 20 , percolation losses from Irrigem tIon, no perched watertables will occur. The aquifer zone should have on hydraulic conductivity of $15.0^{\mathrm{m}} / \mathrm{hr}$ 。 or greater。

Stratification - The solls should have little or no stretiffcation and be more open dowmards so that gravitational water will disappear from the uppor 5-foot zone within 3-5 days or less after an irrigation.

Aquifer Thickness \& Continuity - The aquifer zones should be $6-10$ feet thick and contimous at depths of $3-9$ feet or deeper below the surface. In general the squifers should be edequate to lower the watertable at a rate of 1 foot per day without farn drains but with lateral deep drains spaced not less than $0.3 \mathrm{mile}(0.5 \mathrm{Kro})$ aparto 
Drainage Gredient - Should be greater then .001 in the deep open drains。

21. Depths \& Specings - Genere.17y farin drains should not be needed on the small (5-10 acre) farms anticipated. Deep, open ditch or t1le, accumum lator dxalns at a minimus of $0.3 \mathrm{mile}(0.5 \mathrm{~km})$ may be requirad.

$$
22-\text { GOOD DRAINABH. WYY }
$$

Berrelere - If barrlers to downward water movement are present they should be deep enough to allow a freely draining soll section of not less than $3 \frac{1}{2}$ feet in sandy, $4 \frac{1}{2}$ feet 11 mediun and $5 \frac{1}{2}$ feet In moderetely heavy soils. Upward caplllaxy movement from the groundwater table should be broken or greatly retardod by coarser matorials.

Hydreulic Conductivity and Permosbility - whe solls must have not less than $025^{\mathrm{m}} / \mathrm{hr}$ o nor more than $5.0 \mathrm{~m} / \mathrm{hr}$ 。 permesbility in the solum. In general the soil horizons and substratua ahould be more open downwards and the upward capdi. lary movement be broken or retarded by coarser materlels.

Slower lenses or strata may cause ainor temporarily perched watertables following irrigation but these should disappear by $\frac{1}{2}$ the time between 1 rrigations during the peak season. The aquifer zones should havo a hydraulie conductivity of not less than 5.0 n per hour.

Stratification o There nay be modarately stratified variations in soil and substratru permeability but permeability should genera]. Iy Increase downard. Trapped or perched water above the $4^{\prime}$ level should disappear with normal wator use and drain spseing in the slygt helf of the interval botween ixrigations in the peak irxigation sesson.

Aquifer Thicknesg and Coxtinulty - The squifers may be $2-6$ feet thick, and Ife approxinately 3-6 feet below the surface but should be continuous and should allow the removal of free water to below the $4^{\circ}$ level in $4-5$ days following Irrigations, provided nosmal water managemont practices are used and drains ars properly installed.

Drainage Gradient - Should be not lass than .001.

Drein Spocings \& Depths - Normally these solls should drain with tils or oper ditches at not less than 150 foet apart. Minirum depths would nornally be $4 \frac{1}{2}$ feet for sandy, $5 \frac{1}{2}$ feet for medium and $6 \frac{1}{2}$ feet for heary textured solis.

$$
\text { d3 - PAIR DRAINABTI THY }
$$

Barriers - Barrier depths should be such as to allow a freely drafining sol1 section of not less than $2 \frac{1}{2}$ feet in sandy, $3 \frac{1}{2}$ foet in mediun and $4 \frac{1}{2}$ feet in beaviar solis when drainage facliltias are installed and reasonably fair water management is practiced.

The barrler must be over 1 foot lower and may be several feet lower than above depthe depending on hydraulie conductsvity and grade. 


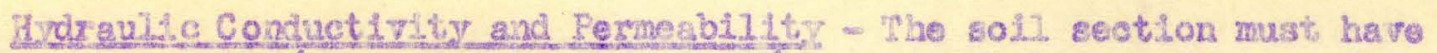
greater than $0.14 \mathrm{~m} / \mathrm{hr}$, and less than $5.01 / \mathrm{h}$ \% permeablilly. The aquifer zonew should have an hydraulic conductivity of not less than $0.5^{\mathrm{M}} / \mathrm{hr}$. Gravitational water should move through the soll profile in less than one-half of the time interval botween ixrlgations in the poak use season when reasonably careful water mangement is practiced and proper dralnage facilities installed.

Stratification - May be stratified io both soll and substratum provided sost of the perched free water can move out of the upper foot within 3 days and down to the desireble drawdown level within one-half of the irrigation period In the peak Ixrigation season.

Aquifer Thiekness and Continuity - The aquifer zones may be 1 foot to 3 feet thick but should bo $3 \frac{1}{2}$ feet or more deep. They may be semi-contimous. They must permit the desirable drawdown within onewbalf of the lirifgation cycle in peak season, assuming congervative water management and drains at a minimus spacing of 75 feet.

Drainage Gradient - Should be over 0.00075 unless pumping and/ox use of artifichally graded drains is feasible。

Drain Spacings and Depths - The minimum spacing of tile or open farm drains is 75 feet for this class. The winimum depths should be $3 \frac{1}{2}$ feet for sandy, $4 \frac{1}{2}$ feet for medium and $5 \frac{1}{2}$ feet for moderately beavy soils, respectively.

$$
\text { dS - POOR DRAINABTIITY }
$$

Barriers - Barrier depths should be over $2 \frac{1}{2}$ feet deep in any soil; should be $3 \frac{1}{2}-4 \frac{1}{2}$ feet deap or deeper with moderately restrictive horizons and moderate Iy permeable soils and $4 \frac{1}{2} 6$ feet deep or deeper with moderately olow aquifers and moderately slow restrictive layers above. The minimum freely draining soll depth should be not less than $1 \frac{1}{2}$ foet.

Permesbility and Hydraulic Conductivity on The soll section may have a minimum permeability of $004 \%$ hroprovided the soil and aquifer zones are more open downwards and no restrictive layers are present. Aquifer permeability may be highly variable but in combination with the soil and barrier depth should perrajt a contimuous transmittal of water through the soll and into the outlet drains such that the upper $18^{n}$ will drain in $\frac{1}{2}$ the irrigation cycle at peak use or 3 days whichever is the longer. Generally the bydraulic conductivity of the aquifer zones must be over $0.1 \mathrm{~m} / \mathrm{hr}$.

Stratifleation $\infty$ Both soil and substratum may be stratified and have perched watertables following lirrigation, provided that perched free water within $18^{n}$ of the surface will move downward within $\frac{1}{2}$ the irrigation cycle or 3 days and, provided that the continuous movernent of water through the soil profile and into the drains is adequate to maintain a favorable salt belance for growth of tolerant legumes and gresees.

Aquifex Thickness and Continuity - May be discontinuous and less than $16 \mathrm{~m}$ thick. A minimum continuous squjfer of $6^{\mathrm{n}}$ of very rapidly permeable fover $5 \mathrm{~m} / \mathrm{hr}$.) materials may be permitted if other conditions axe favorable. Perched watertables or blocked water movement may exist but the upper 18\% of soll should drain out in $\frac{1}{2}$ the irrigation cycle or 3 days whichever is the longex. Moderete growth of water and salt-tolerant grasses and legumes, or trees and shrubs on over $75 \%$ of the area laust be feasible with careful water manegement and drains at a minimum spacing of 33 feet (10 meters or 1 normal border width)。 
Dralnage Gradisnt a Should not be Less than .0005 unless pumping and/or use of artilicially graded drains $1 \mathrm{~s}$ fossible.

Drain Spacings and Depths - A minimum of a normal border width of 33 foet or 10 meters is assumed the closest specing practical under any circumstances. A minimum depth of tile or open ditch of $2 \frac{1}{2}$ feet is assando With these minlmum conditions Imposed the solis and squifers should be sush as to a.llow a

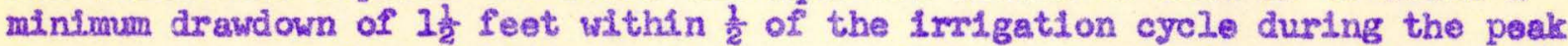
use season or 3 days, whichever is longer. The movement of water through the so11. Into the drains and substratun mut be such that a salt balance favorable to moderate production of salt and water ctolerant grasses and legumes can be maintained。

\section{Q5 - VERI POOR DRAINABILITT}

Barriors - Less than $2 \frac{1}{2}$ foet with any soll condition above: sad generally less than $3-4$ feet with moderately slow permesbility above or loss than 5 foet with slow permeability above。

Pexmeability and Hydraulic Conductivity - Less than $0.04^{\mathrm{m}} / \mathrm{hr}$. soll per meability or $0.1^{\prime \prime} / \mathrm{hr}$. substratum permeabli1ty, or any gtratified condition that w1Il not perwit removal of watertable below $1 \frac{1}{2}$ feet within the irrigation cycle during the peak season of use or 3 days, whichever is the longer, when minimun ditch spacing is used.

Stratiflcation - Extreme variation in hydraulic conductivity of soll and substratum lenses within 3 feet or less of the surface such that the abovondesm crlbed drainage requirements cannot be moto

Aquifer Thickness and Continuity - No apparent aquifers or less than $6^{n}$ thickness of permeable materials in discontinuous strata.

Dralnage Gradient - Less than .0005, witk purning and/or artificially graded drains not feasible. deptho

Draln Spec1ng and Depth - Less than 33 feet spacing or less than $2 \frac{1}{2}$ feet

Note: Again it must be emphasized that the above drainability classes are based ox the physical criteria considered necessary to meet the requirements of the land canablilty classes, and do not reflect economics of development except as applied to a particular situation where all cost and production factors are known。 
c. Drainability Class Limitso The drainability class limits summexized in Jablo 42 are based on consideration of the adaptation of crops to different levels of drainage as well as to the physical factors affecting drain spacings, and depths. Comparison was made with a number of $U$. S. publications on drainage standards. The criteria assumed for Class I drainability may bo sonewhat too strictly drawn. Highly productive solls of Class I quality may require somewhat closer drains than indicated. At the other extreme the limits for cless IV lands parmit the growth of water tolerant legumes and grasses or such crops as rice for which sub-surface drainage may not be necessary. The minimum drain depth of $2 \frac{1}{2}$ feet is 11 sted in several U. S. publications. The minimum mid-t21e drawdown of $18^{n}$ conforms to the soll depth limitations for Class IV lands. Similar considerations were used in arriving at class limits of the other two classes. Ilustrations of various drainability conditions are given in drawings following (Cablos 43, 44, and 45\%

d. Quantities of Weter to be Romoved by Droins. The quantity of perco lation waters that must be removed by drains is largely a function of 1rrigation efficiency. Factors affecting irrigation efficiency are the capecity of the soil to hold water, the rate of intake, the care with which the field is leveled and laid out for uniform 1rrigation, the time and rate of application of 1xrigation water, and the percolation losses in the distribution system. The intake rates and storage capacittes of the major solls are discussed in Chapter IV. In Chapter VII on Water Use Practices the differences in solls and their affects on planning efficient Irrigation layouts will be given further tbeatment.

Israelson states that punping $1 / 3$ of the total irrigation water used in the Salt River Valley, Arlzona, continues to lower the water table. Houk quotes data on ground water seturn flow including South Platte - .0036 efs/acre, N. Platte (Whaten Dam to N. Platte) $=0042 \mathrm{cfs} / \mathrm{acre}$, Californis daltas - .006, San Joaquin Valley - .015, Rio Grande - .005, and San Luis Valley, Colorado - .003 efs/acre, or generally .003 .006 $\mathrm{css} / \mathrm{acre}$

Table 46, shows the rate of drain removal required for different amounts of 5.xigation, percentage losses and time of drawdown. As long as the vater recedes to the normal depth by $1 / 2$ the irrigation cycle some plants can stand louger drawo down periods than indicatod.

C. Economics of Drainege. Several inter-related factors enter into the economic considerations of drainage. Madimum production value with minimum capitel Investment is of course the ideal but not always attainable goal. Where private captal is being invested for a purely profit notive careful consideration world be given to all costs and to expected returns. Where public velfare is the primary and long-tern objectlve, the political and soclal rage to develop land and water resourcos may accept difficult and extraordinary tasks as feasible. The people of the Netherlands have struggled against the seas through wars and typhoons to reclaim lands from under the salty waters. Eight to ten years are required after the sea waters are pumped out bafore the lands are quite ready for use.

A piece of land may grow certein water tolerant gresses and legumes and return a relatively low Income as pasture with little or no expense for drainage. On the other hand drainage properiy installed and maintained may allow the production of high value crops that will over a period of years offset the costs of drainage. 
SUGGESTED DRAINABIL XIY LIMTIS FOR LAND CLASSES IN IRRIGATED AREAS

\begin{tabular}{|c|c|c|c|c|}
\hline $\begin{array}{c}\text { Land Class } \\
y\end{array}$ & $\begin{array}{l}\text { Drain } \\
\text { Spacing } \\
\text { (foet) }\end{array}$ & $\begin{array}{c}\text { Drawdown } \\
2 /\end{array}$ & $\begin{array}{l}\text { Depth } \\
\text { to Tile } \\
\text { (feet) }\end{array}$ & $\begin{array}{l}\text { Grade of } \\
\text { rile or } \\
\text { pitch }\end{array}$ \\
\hline Class I & $\begin{array}{l}\text { No farm } \\
\text { drains reqo } \\
\text { Lateral doep } \\
\text { drains over } \\
\frac{1}{2} \text { Km. way be } \\
\text { needed. }\end{array}$ & $\begin{array}{l}\text { A11 areas } \\
\text { freely drained } \\
\text { to below } 5 \\
\text { in mediun \& sandy } \\
\text { \& below } 68 \text { in } \\
\text { besvy solls. }\end{array}$ & $\begin{array}{l}\text { Oniy wide } \\
\text { spaced laterea } \\
\text { als required. } \\
\text { Depths over } \\
\text { 8' deslred. }\end{array}$ & $\begin{array}{l}\text { bpen ditches on greater } \\
\text { than } 001 \text { grade. }\end{array}$ \\
\hline Class II & Mino of $150^{\circ}$ & 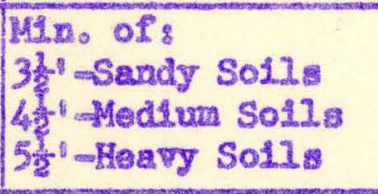 & 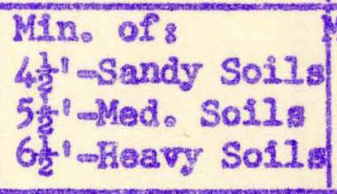 & pino of 001 gresde \\
\hline Class IXI & Mino of $75^{\circ}$ & 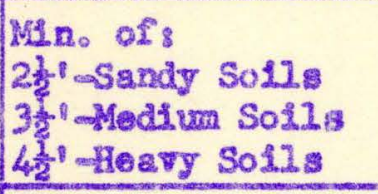 & $\begin{array}{l}\text { Min of } \\
3 \frac{1}{2}-\text { Sandy So118 } \\
4 \frac{1}{1}=\text { Med。 So11s } \\
5 \frac{1}{2}=\text { Heavy So11s }\end{array}$ & $\begin{array}{l}\text { Min. of } 00075 \text {, unless } \\
\text { pumping and/or use of } \\
\text { artificially greaded } \\
\text { drains is feasible. }\end{array}$ \\
\hline Class IV & Min, of $33^{\circ}$ & Min。 of $1 \frac{1}{2}$ & $M d n_{0}$ of $2 \frac{1}{2}$ & $\begin{array}{l}\text { Min. of } 0005 \text {, unless } \\
\text { pumping and/or use of } \\
\text { artificially graded } \\
\text { arains is feassiblo. }\end{array}$ \\
\hline Pless V & $43 \%(10 \mathrm{M})$ & $0 \frac{1}{2}$ & $22 \frac{1}{2} 8$ & $\begin{array}{l}\text { Fo005 (pumping and/or } \\
\text { use of graded } \\
\text { drains is not } \\
\text { feasible. }\end{array}$ \\
\hline
\end{tabular}

1/ These reinirum requirements are ccmputed from physical conditions which are noces sary to conform with the land capability class definitions. They reflect econe omfes of development only where costs and production are known quantities.

2f Drawdown is generally assumed to be the normal depth to groundwater. However it is calculated at the point midway between tile lines or point of least recession. The time interval assumed for calculation is $\frac{1}{2}$ of the tine interval bow twenn successive irrigations at peak 1rrigation demand, or a minirum of 3 days. 
Example of d-2 Dratnablitty

$28.3=07$

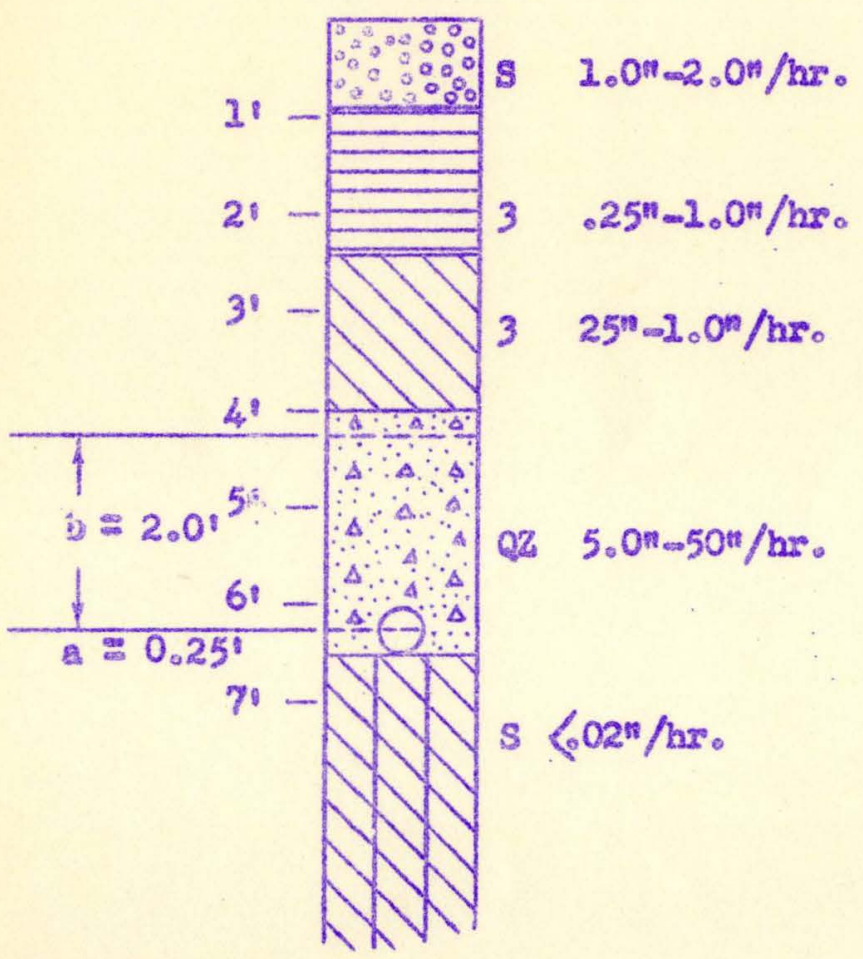

Colouiations:

TRAM $=4.0{ }_{3}$ Ixr。Frog. 15 days。

$Q=.002$ ess at $10 \%$ \& .006 efs at $30 \%$

Assume drawdown = $4 \frac{4}{2}$

a $: 0$ ox $025^{\circ}$ is $\approx 2.0^{\circ}$

$S=\frac{\sqrt{4 \times 9\left(2^{2}-.25^{2}\right)}}{.006} \approx 154$

$s=\frac{\sqrt{4 \times 5.0(22-0)}}{.002} \cdot 630^{\circ}$
Exarnples of des Drainabillty 31325

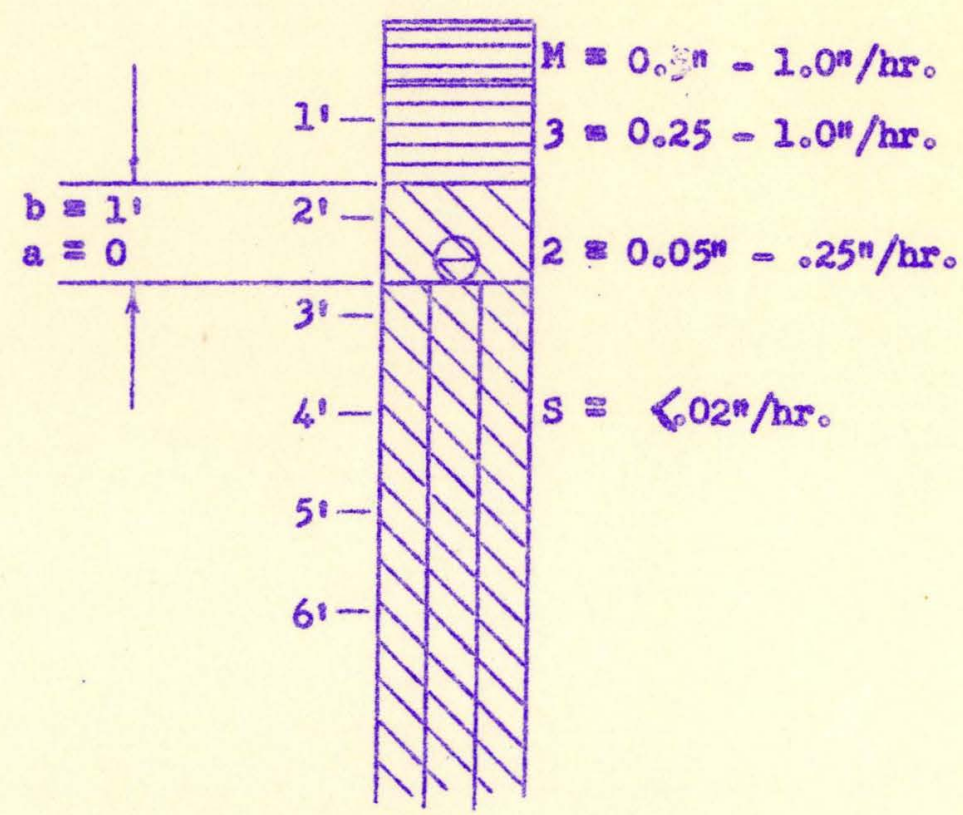

\section{Calculations:}

TRAM 2.5 Irr. Frog。 $\$ 8$ days。

$Q=.0026 \mathrm{cfs}$ at $10 \%$ and .01 cfs at $30 \%$

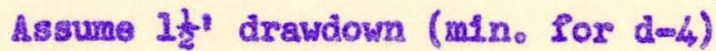
$s=\frac{\sqrt{4 x .2 \times 1^{2}}}{.0026}=17.5^{\circ}$
$S=\frac{\sqrt{4 \times 02 \times 12}}{.01}$
$9.0^{\circ}$ 


\section{Table 44}

\section{Example of des 3 Drainability $243 q^{3}-25$}

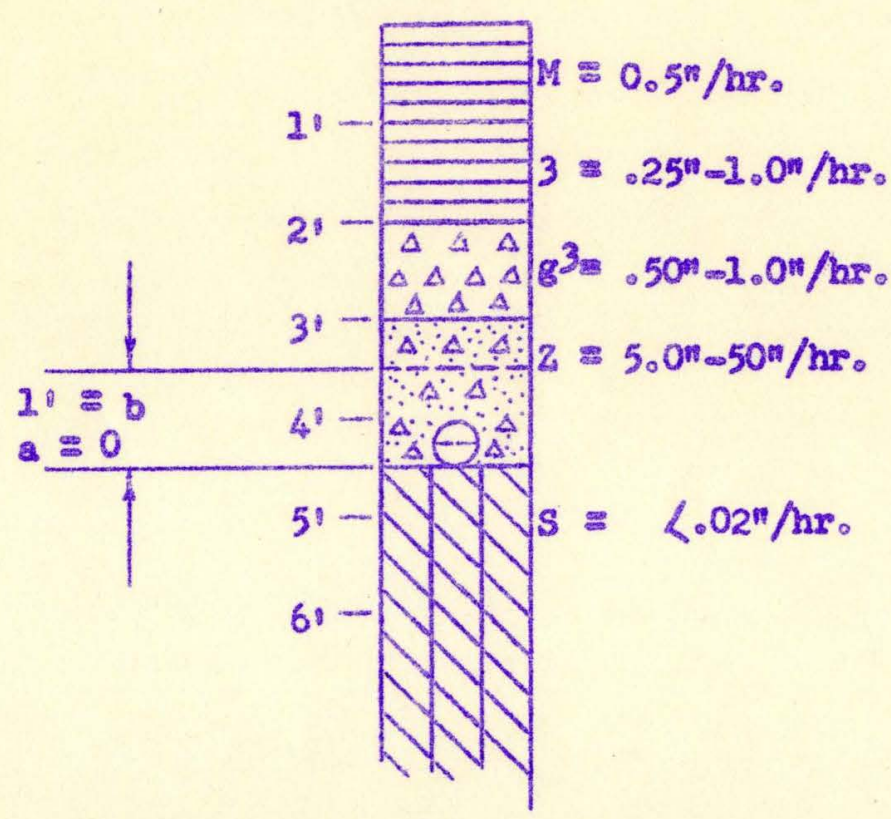

Calculationg:

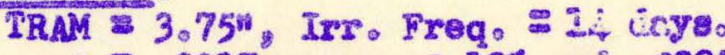
$Q=.0027$ cusecs $2.10 \%$ and .0095 cugecs (2) 30\% 10ss

Aรsune $3 \frac{1}{2}$ drawdown:

$$
\begin{aligned}
& s=\frac{\sqrt{4 \times 5\left(1^{2}-0^{2}\right)}}{.0027}=87^{\circ} \\
& s=\frac{\sqrt{4 \times 14\left(1^{0} \times 0^{2}\right.}}{.0095}=75^{\circ}
\end{aligned}
$$
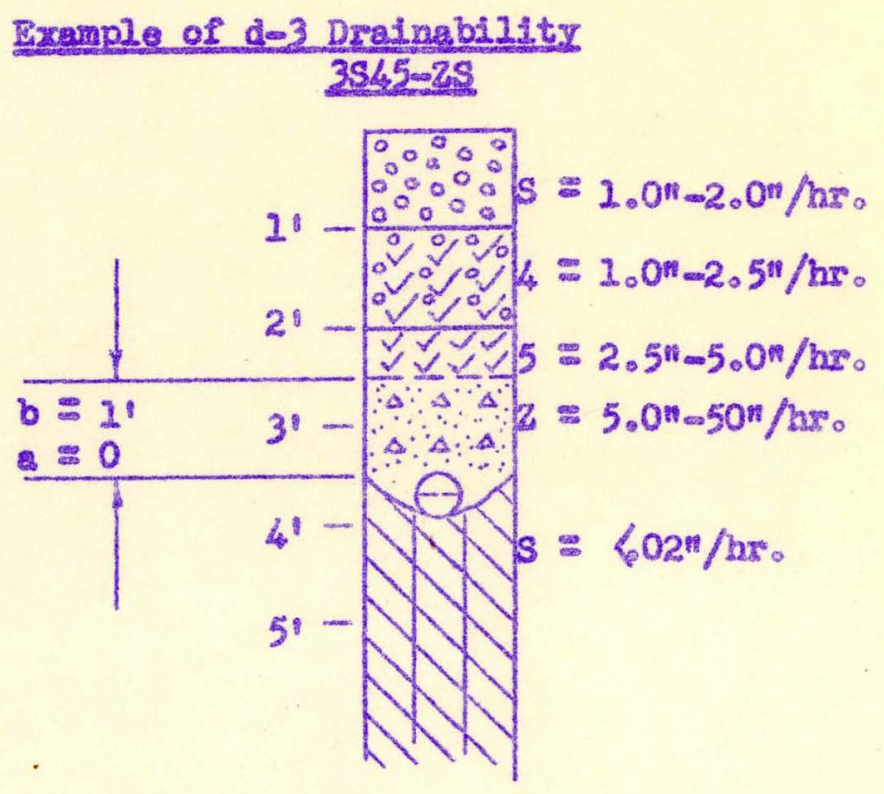

Calculations:

TRAM $=2.5^{m}$ Ixr。 Freq, $\$ 8$ day.

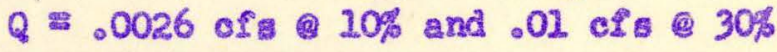

As $2 \frac{1}{2}$ dxwewdown:

$$
\begin{aligned}
& s=\frac{\sqrt{4 \times 5\left(1^{2}-0^{2}\right)}}{.0026}=88^{\prime} \\
& s=\frac{\sqrt{6 \times 14\left(1^{2}-0^{2}\right.}}{.01}=75^{\circ}
\end{aligned}
$$


Takle it5

Examplo of deb Drainability

$$
2532-5
$$

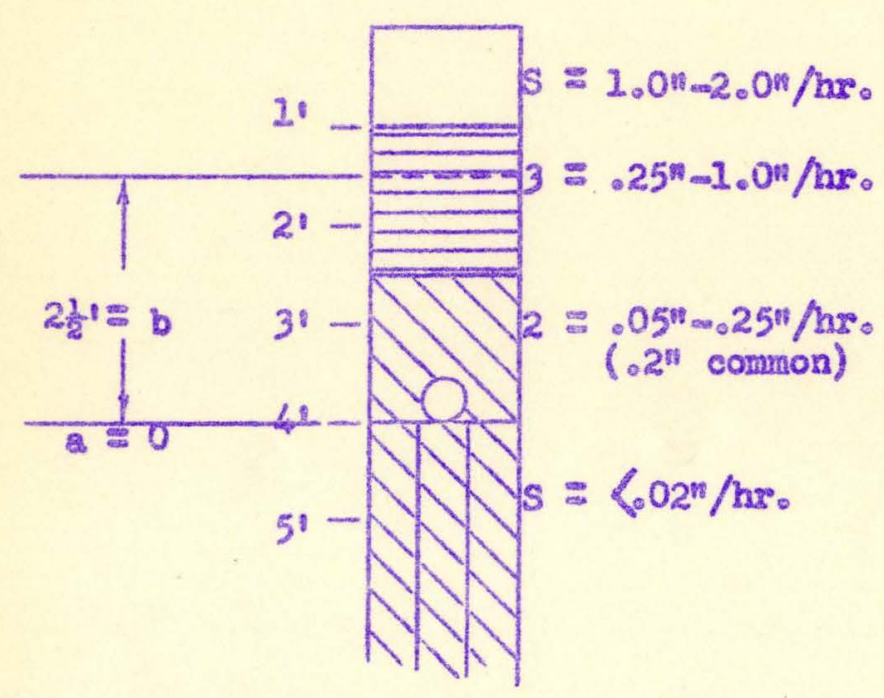

\section{Calculat1ons:}

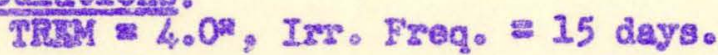

$Q=.002$ ef at $1.0 \%$ and .006 of a $x_{j}-\Delta=0$.

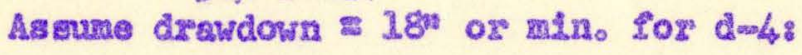
$a=0, b=2 \frac{1}{2}$

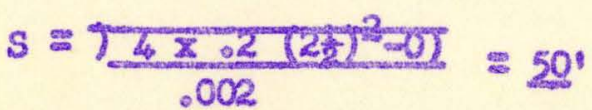
$s=\frac{\frac{\pi .5(2 \pi)^{2} 0}{.006}}{0.030}$

Example of dods Drainability

$4 M 3-0 Z S$

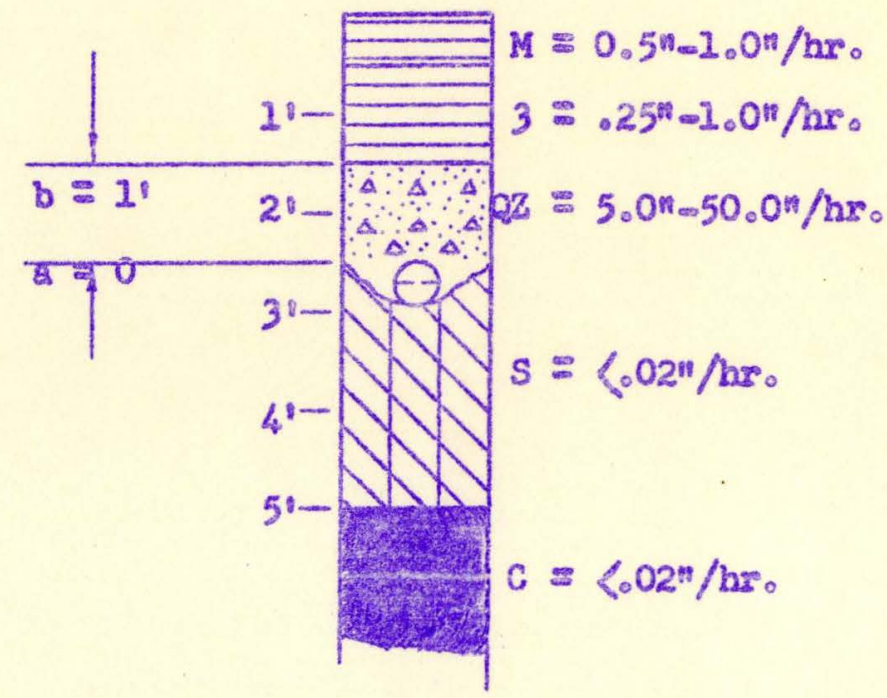

Calculations:

TRAM \& 1.8", Max.Irr. Freq。 = 5 days。

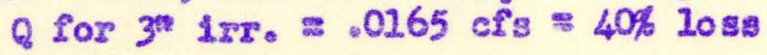

Assume rin. drewdown of $18^{7 n} \mathrm{~g}$
$a=0, b=1^{\prime}$
$s=\frac{\sqrt{45\left(T^{2} 0\right)}}{.0165}=34$ 
Novesaber 15,1956

\section{DRAINACE TERYS AND EOUIVALENSS}

(Parcolation, Infiltration, Permoability, Hydraul1c Conductivity)

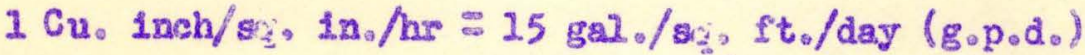

$$
\begin{aligned}
& \text { " } 2.31 \times 10^{-5} \text { cu. } \mathrm{ft} / \mathrm{se}, \mathrm{ft} / \mathrm{sec} \text { (crs, Cusec) } \\
& =2.54 \mathrm{cc} / \mathrm{cm}^{2} / \mathrm{hr},\left(\mathrm{cc} / \mathrm{hr}^{\circ}\right)
\end{aligned}
$$

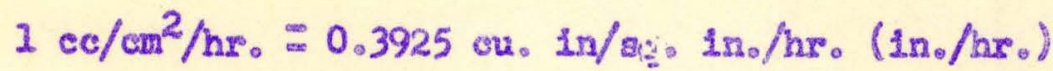

$$
\begin{aligned}
& =5.9 \mathrm{gal} / \mathrm{sg} \mathrm{g}_{\mathrm{s}} \mathrm{ft} / \mathrm{day}\left(\mathrm{g}_{0} \mathrm{p}_{0} \mathrm{~d}_{0}\right) \\
& =9.1 \times 10^{-6} \mathrm{cu} \cdot \mathrm{ft} / \mathrm{s}, \mathrm{ft} / \mathrm{sec} \cdot(\mathrm{cfs})
\end{aligned}
$$

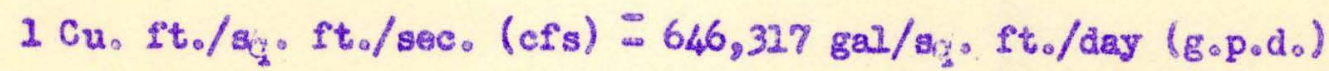

$$
\begin{aligned}
& =43,200 \mathrm{in} / \mathrm{s}_{0} \mathrm{in}_{0} / \mathrm{hr}_{\circ}\left(\mathrm{in} / \mathrm{hr_{0 }}\right) \\
& =109,728 \mathrm{cc} / \mathrm{sq} / \mathrm{cm} / \mathrm{hr}_{\circ}\left(\mathrm{cc} / \mathrm{hr}_{\circ}\right)
\end{aligned}
$$

\begin{tabular}{|c|c|c|c|c|c|c|c|c|}
\hline \multirow{2}{*}{$\begin{array}{l}\text { rx. Rate } \\
\text { Inches }\end{array}$} & \multirow{2}{*}{$\begin{array}{l}\text { Allowable } \\
\text { Dreudowa } \\
\text { time } \\
\text { In days }\end{array}$} & \multicolumn{7}{|c|}{ Cis./acre drain removal required at varying percolation Iosses } \\
\hline & & $5 \%$ & $10 \%$ & $15 \%$ & $25 \%$ & $30 \%$ & $40 \%$ & $50 \%$ \\
\hline \multirow{3}{*}{3} & $3(72)$ & $\frac{\mathrm{CP}_{\mathrm{s}}}{0021}$ & $\frac{\mathrm{cfg}}{2}$ & $\frac{\cos }{0063}$ & $\frac{\mathrm{cfs}}{\mathrm{s}}$ & อน์ & $\frac{\mathrm{cfs}}{676}$ & cfs \\
\hline & $5(120)$ & .0013 & .0025 & .0038 & .0063 & .0075 & 0100 & .013 \\
\hline & $7(168)$ & .0009 & .0018 & .0027 & .0045 & .0054 & .0072 & .009 \\
\hline \multirow[t]{3}{*}{4} & 3 & .0029 & .0055 & .0083 & .0139 & .0266 & .022 & .029 \\
\hline & 5 & .0017 & .0033 & .0050 & .0083 & .0100 & .0133 & .0167 \\
\hline & 7 & .0012 & .0024 & .0036 & .0060 & .0072 & .0095 & .0220 \\
\hline \multirow[t]{3}{*}{6} & 3 & .0042 & .0084 & .0125 & .021 & .025 & .033 & .042 \\
\hline & 5 & .0025 & .0050 & .0075 & .0125 & .0150 & .0200 & .025 \\
\hline & 7 & .0018 & .0036 & .0054 & .0089 & .0108 & .0244 & .0178 \\
\hline \multirow[t]{3}{*}{8} & 3 & .0055 & .0111 & .0167 & .0278 & .0334 & .0445 & .0555 \\
\hline & 5 & .0033 & .0067 & .0100 & .0167 & .0200 & .0266 & .0333 \\
\hline & 7 & .0024 & .0048 & .0072 & .0119 & .0143 & .0190 & .0238 \\
\hline \multirow[t]{3}{*}{10} & 3 & .0069 & .0139 & .0208 & .0278 & .0415 & .0555 & .0695 \\
\hline & 5 & .0042 & .0083 & .0125 & .0208 & .0250 & .0333 & .0415 \\
\hline & 7 & .0030 & .0060 & .0089 & .0149 & .0178 & .0238 & .0298 \\
\hline \multirow[t]{3}{*}{12} & 3 & .0083 & .0167 & .0250 & .0333 & .0500 & .0667 & .0833 \\
\hline & 5 & .005 & .0100 & .0150 & .0250 & .0300 & .0400 & .0500 \\
\hline & 7 & .0036 & .0072 & .0107 & .0278 & .0244 & .0286 & .0357 \\
\hline
\end{tabular}

Table 46

IRRIGATION DRAINAGE REQUIREMENTS - CFS/ACRE

Based on rates \& frequency of irr. and percentage percolation losses。

T.F.S./Acre $\times 1.9835=\mathrm{cu} . \mathrm{fto} / \mathrm{sq} . \mathrm{ft} \cdot / \mathrm{day}$

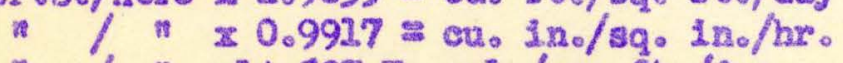

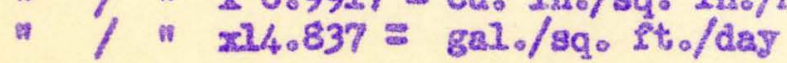


In the Helmand Valley it appears certain from studies made so far that produetion levels of most solls of the projects will be coupled with how well these lands are drained and the drains maintained. Estimates of drainage costs have ranged from as low as $\$ 30.00$ per acre to as high as $\$ 300,00$ par acre for various

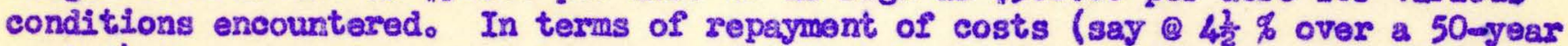
perdod) Hissge require a net inerease of 1 bushel of wheat per acre on the first soll and 10 cushels per acre on the second. Unfortunately some of the loast productive soils, as in the case of the Nad-1-Al1, Marja and Serej desert bench, may require the greatest expenditures for drainage. For some of the more difficult areas the best choice appears to be the growth of special crops adapted to waterlogged, saline situstions.

The failure of some of the tile lines in Nad-i-Ali caused by plugging with plant roots, silting of tile or other causes has led to a bellef that open dreins will be best for Afghan farmers. This may well prove to be an unfortunate cholce. In the flrst place open drains dug at proper depth and side slope are more expensive to install than tile drains. Maintenance will be much greater in the long run. The tile that were plugged with willow roots were placed not over 20 feet from fair sized willows. No water-loving trees should be within 100 feet of tile Iines. The plugging of some tile by camel thorn was a cause for general disnay and a cry of failure. A fow years of consistent spraying with the proper chemicels would elininate camel thorn or any other such obnoxious plant and at very low costs. Open ditches will telke land out of production at the rate of $1.5 \%$ for every line installed. Thus 100-meter spacing deletes 15\%, 50-meter 30\%, and 25-meter $60 \%$ of the land area. As the cost of drainage goes up, the acreage which should bear the cost of developanent goes down and the gross product also goes down. In the Nad-1-Als, starting with an initid al arable area of 18,500 acres, assuming the same unit price and comparing open dreins vso closed dreins on a costs production ratio, the open drains would cost (300 meter spacing - 1.4 times t1lo drains, (3) 50 meter spacing - 2.03 times, and at 25 moter spacing - 6.3 times the cost of tile drains. The number of usable acres reduces to $85 \%$, $70 \%$ and $40 \%$, respectively, of that available. Since some lands in the Nad-i-Al1 will require less than 100 meter spacing it appears impracticel to consider open farm drains as a long-time solution. The extra costs for other structures and the greatly increased costs of maintenance and operation amidst this maze of open drains was not considered in the above comparison. A I1ttle common sense direction in the correct installation of t1lo drains and the use of a fow dollars worth of cheni-m cal sprays can save millions of dollars lavested in an unsightly and less proc ductive ares. Farmers can bo taught how and difected to install t1le drains. provided tile, gravel and technical assistance are furnished. The cash outlay could be greatly reduced and the land saved for crops which is after all the goal of the whole development program. 
In the Halmand Valley large areas of solls are presently either unproductive or of low productivity because of an excess of salts, alkal, boron or a combination of thess. The program of project development must concern itself eventually, therefore, not only with irrigation distribution and drainage syoterns but with measures to remove and control salinity and alkelinity, include Ing the adoption of crops and cropping practices which will maintain as high a level of production as the non-renovable alkalinity end sallinity will allow。

Physical Factors affecting the successful reclamation and managenent of such soils include (1) depth and permeability of soll, (2) presence or absence of groundwater tables and character of groundwater, (3) permeability of the sub = stratum and drainability (Including outiots) of the area in question, (4) total concentration and quality of the salts present, (5) bese exchange capacity and degree of sodium saturetion of clays, (6) quantities and distribution of gypstus or other calelum salts in the soll and in secesaible nearby deposits, (7) total salts of each kind and percent of sodium salts in irrigation waters, and (8) climatic factors affecting adapted crops, ratos of evapostransplration and rates of drylng out of solls which conduct water upward from groundwater tables.

Fconomic or Soclal Fretors determining the feasibility of reclaining saline or alkaline soils include, in general, the cost-benefit ratios and the national or provincial sociomeconomic and sociompolitical necessity or urge for bringing such lands into production. The latter may overweigh unfavorable cost-banefit ratios which are based primarily on agricultural production and marketing costs compared with net income Irom sale of agricultursI products. In Afghanistan, labor is cheap and there are severel months of 1dle time for a wheat farmer to spend or dralnage work. If he can be properly directed, as for instance by the HVA and FOA toams, the actual cash outiay for on-farm dralnage could be reduced by providing only the tilo, gravel mantio, and engineoring services. It is estio mated esch farmer could lay his own tile field in $3-5$ years or dig narrow open drains in loss time. It is urgent that this progran be given serious attention, since it is obvious that dralnage is a prerequisite to a sound development prow gram in this area.

Leaching of salts and other reclamation practices also can be carried out by the farmer if he is given careful supervision and guidance. The network of major project drainage will require the best technical sleills for planning, layout and construction, however.

The following discussion of reclamation, treatment and managenent of saline and alkall solls $1 \mathrm{~b}$ based on data from various parts of the world. It is arrang= od In such a way that treatrents generally applieable to a given soli condition can be determined from the solls maps and laborstory data on completion of doe tail surveys and final classifieation of a given area. Each tract of land wijl require careful atudy and appratsal to determine tho most pregetical and economic methods to use but the following will serve as a general guides 
a.j Drainges:

Salinity and alkalinity of the soil horizons are generally results of, (1) upward and latoral movernent of solutes from groundwaters, or (2) deposition by evaporation of saline runoff waters in flelds or in naturel eatchmont basins, or (3) weathering and redeposition from geologic forwations, or (4) resuits of irrigation or flooding with saline waters those solls which have inadequate drainage, or (5) continued irrigation with Iimitad anounts of seline waters so that no deep percolation occurs and aelts accurnulate at or near the surface. In any case, success in reclamation treatment and management depends to a great extent on the adequacy of dreinage.

1. Natural drainage. Deep perneeble solls having no deep groundwater tables allow salts and alkali to be removed below the normal plant root zone by natural leaching or by treatment with heavy irrigations. Salts will not reo accumulate as long as there is no groundwater sufficiently high to establish captllary movement to the surface. Permeable solls over reapidly permeable substratum, such as sand and gravel which of fer opportunity for rapid removal of percolation waters, have ideal natural drainage. Generally such soils are not now seriously affected by salts or alkall. Where there is inadequate natural. drainage, artificial drainage must be applied.

2. Artificial drainage consists of two main types, suriace and subsurface. The use of these singly or in combination depends on the conditions to be met.

a. Surface drains generally are designed for removal of excess irrigation waters and storm runoff. Their design and construction is based on meetIng these two requirements and they are commonly needed on most irrigation developments.

(1) Surface flushing drains for inftial reclemation and manago ment of saline or saline-aikali solls constitute a special treatment where, (a) solls have such slow topsoll or upper subsoll permeability as to linit use of deop subsurface drains, or (b) have a permanent non-removable watertable of salins waters at depths which cause recurrent capillary rise of salts, or (c) have a very heavy salt encrustation at the surface, part of which can be renoved by surface flushing before starting leaching. Generally such drains are constructed in a network equal to the individual irrigation borders. Each irrigation border may be surrounded on three sides by flushing drains. These third class drains are usually 3 to 4 feet in depth with minimur cross section. The exceam rated soll material is used to build border dikes or excess soll may be spread onto the land and leveled.

For soils having slowly permeable upper horizons and heavy salt encrugtam tion at the surface the general procedure would include use of maxdmum nonerosive heads of water. Prior harroving to loosen and break up the salt crust and harrowing during the movement of water down the border with rapid removal of the rater through the Ilushing drains is necessary. Oniy the dissolved salts and some suspended materials may be moved off the fleld. The water which percoe lates below the dopth stidred by the harrow is ineffective in removing salts. 


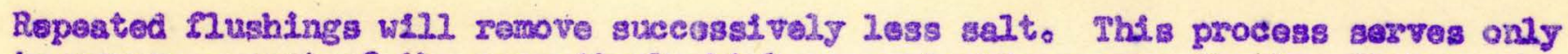
to remove a part of the oxceedingly high concoxisations near the lmadiate suxface. Following flushing by looding, the land should bo allowed to dry and crack, then be roughanplowed or ripped and cross ohecks Inetalled for leaching. Gypgra should be applied to alkall axeas at this thmo

Laaching way roquire some timo if the subsolls are slowly parmeable. After standing for long porlods, water should bo drained off allowing for dxying and cracking to take place. Then fresh water mey be added. If rice 1 grown as reclamstion erop, stagnant waters must bo drawn of 1 into the surface drains and Iresh water added as noeded for rlce culture.

b. Subsurface drainage Includes three general types: open drains, covered or tile drains, and punps. Cenerelly all main outlet drains for an area will be of the open type. The use of open 2 nd and $3 \mathrm{rd}$ class (on-farm) drains Is less dosirable then tile drains becauss of, (1) greater excavation coøts, (2) grezter difficulty and cost of maintenance, (3) Incroased costs for surface dip. tribution syatems, rosds and other surface structures, and (4) removal from cultivation of constderable land which could otharwise be in crops. On the other hand open farm drains may be necessary where (1) slowly permeable Iayers alterm nate with parneable layers in such a vay that an open drain would be more offoce. t1vo, (2) surface flushing and partial subsurface drainage must bo conbined, or (3) the cost of tile drainage exseeds the combined costs of open drains desm cribed above, or (4) tile cannot be had and farmers do not underatand t1le installation or maintenance of tile drains including control of plants which clog drains by deep root growth. Each set of $20 \mathrm{cal}$ conditions must be carefully welghed before recommending the type of dralns or combination of types to be usod.

c. Pumping for drainage. (1) Pumping as a means of lowering groundwater tables may bo feasible, (a) where deop, slowly permeable ailts oxtend be low practical t1le or open drain depths but have no barxlers and extend to good aquifers in the groundwater table, (b) whare arteslan pressures can be ranoved snd, (c) where 1 migation by punp water is feasible and can help offset the costs of drainage by this method.

(2) Artesian water can also be released by gravel sumps into deep open drains or t1le dralns. In aome cases rock may limit the practical depth of excavation and yet may confine water under pressure. Wherever flssures occur this water wlll be forced upward into the soll creating local wet areas whlch are not relieved by open drains or tile. In such eases it may be possible to blast thru the rock in the botton of the ditch and construct a gravel-packed "well" or sump into the equifer below the rock. Water will then rise and flow in the open diteh or tile drain and help relieve the hydrostatic pressure. Attempts should be made to locate any sources of arteslan water guch as canal leakage or wagtage of water farther up the slope whlch can be relieved at the source.

d. Reduction of water percolation losses. One of the nost urgent needs In 211 projects and one that will greatly reduce the cost of construction and maintenance of drains is the careful control and use of 1rrigation waters. Studies of farmer Irrigation in Nad-1-Al1 in 1956 revealod an average eff1ciency of 20-30\%. Not much of this waste water ran off the surface so that $60-70 \%$ of all the water used by the farmers was entering into the groundwater table. The ratio of con- 
duetivity of 2rrigation weter and drainage (groundwater) Indieatos that $10 \%$

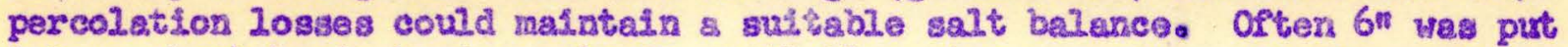
Into a check-basin having only $2^{\text {" }}$ available water capacity. Studios made in the dry year of 1955 by ICA showed the Patow Canal to be teking in 300-400 cusece at the upper and after whest harvest and when $100-150 \mathrm{cusecs}$, with reasonable effleiency, would have axply served 211 erops.

Measurements on a 19-kilomotor stretch of wa isity Canal in 1953, before lining, showed losses of 50 cusecs out of 300 cusecs entering the upper and of the messured section. Some irrigation ditchos run day and night when not a farmer is in the f101d. All of these 11lustrate the intolerable wastage of vater which aggravatos the drainage and salt probiens of the Helnand Valley. Proper allocation and distributson of weter on regular rotation irrigation schedules would do much to reduce water wastage. IIning of canals, puddling clay into sub-laterals and form ditches and using better leveling and Irrigation techniques would all naterially lessen the burden of drainage, reclanation and maintenance necessary for successful use of the land. This is a contribution to Afghan agxiculture that cen be schieved only gradually but thru patient teachIng and demonstration, and through organization of responsiblo local authority with adequate technical guidanco.

The Afghans have in only very few instances shown that they understand the noed for drainage. In the Seraj, where a fow farmers have dug relatively shallow open ditch drains, some formerly barren, highly saline-alkall lands have been put into cultivation. Generally it appears from observation and mapping that irrigated tracts are boxdered by non-1rrigated tracts where the salts can accumulate. If waterlogging forces abandonment the farmer moves to another site. However, it also appears that uniess the watertable remains too high maxy aline solls can be leached and crops raiged. Therefore the chief cause of failure appears to be inadeguate drainage rather than extreme difficulties of leaching and removal of alkali. Once the drains are properly Installed the farmers can under guidance of HVA and IIA proceed to do reclamation work with their own labor as the principal cost itew. The results of several reclamation trials conducted to date on very severely saline-alkali lands indicate that all but the heavy very slowly permeable clays can be leached of excess salts and the exchangeable sodium redueed enough to allow crop production. See Tablo 47.

$$
\text { bosching: }
$$

Leaching constitutes removal of soluble galts from the root zone by movew ment of water thru the soll prof1le. Preferably, water should move into under ground aquifers or drains which carry the salts away from the area permanently.

1. Salt Balance. More salts must move out of an area than are added by aruface irrigation if the leaching program is to be successful in permanentiy rem moving salts. For excample I acre foot of Arghandab rivor water, considered of excellent quallty, will add 0.1 tons of harmful salts to a soll. The average annural application is about 31 acrefeet por acre. The harnful salts added would be .34 tons per acre of soil. To maintain a favorable salt balance, assuming $20 \%$ overall percolation losses, the groundwater moving out of the area must carry at least 380 parts per million of harmful salts or about 5 times as much 


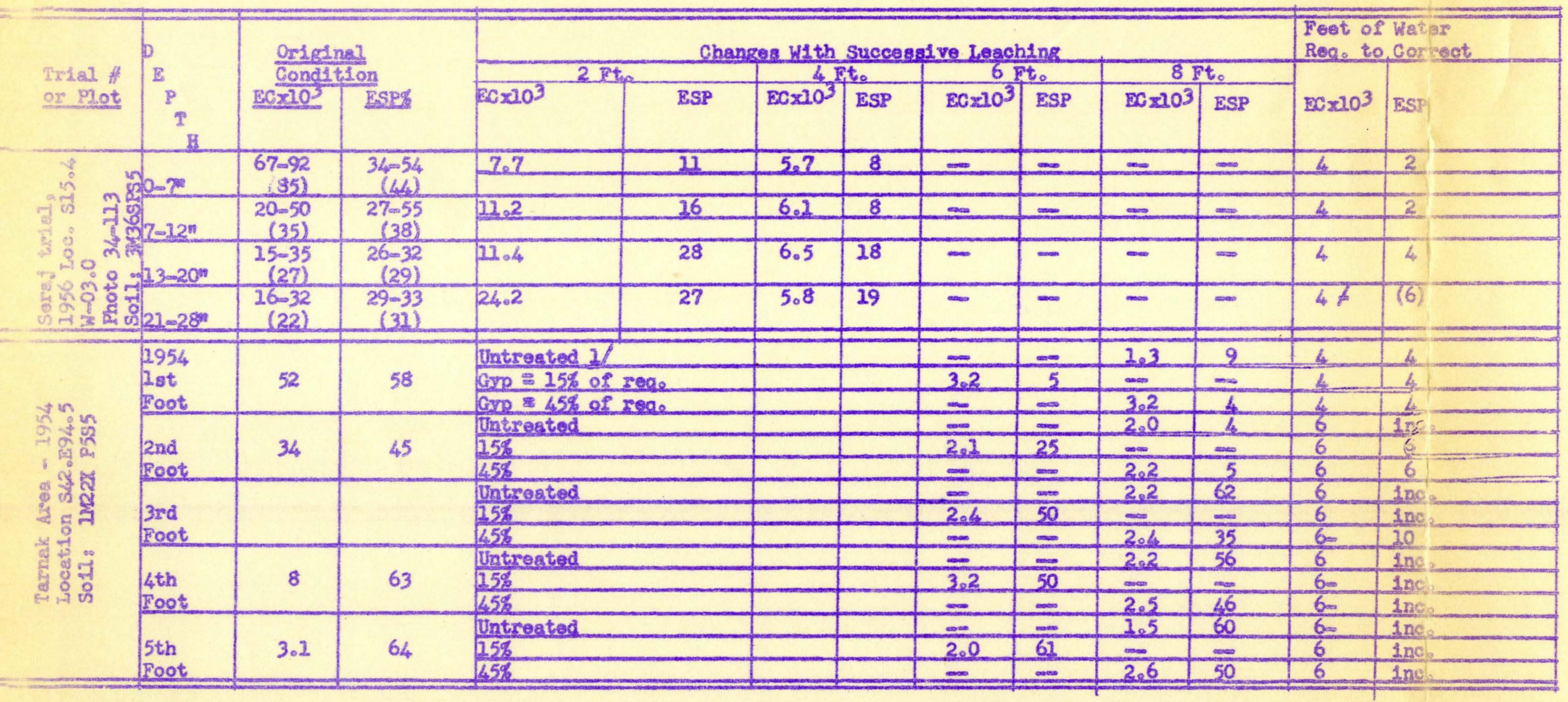

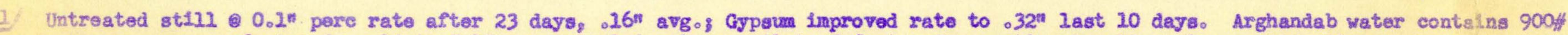
Eypsum per acrefoot and would 1n 5 w0 years reclalm above soll to 5 feet。 In mesntime leaching alone would allow crops to growo 


\begin{tabular}{|c|c|c|c|c|c|c|c|c|c|c|c|c|c|c|}
\hline \multirow{3}{*}{$\begin{array}{l}\text { Trial } \\
\text { or Plot }\end{array}$} & & \multirow{2}{*}{\multicolumn{2}{|c|}{$\begin{array}{l}\text { Original } \\
\text { Cond1t1ons }\end{array}$}} & \multicolumn{8}{|c|}{ Changer With Successive Leachings } & \multirow{2}{*}{\multicolumn{3}{|c|}{$\begin{array}{l}\text { Feet of Water } \\
\text { Reqe to Correc }\end{array}$}} \\
\hline & & & & \multicolumn{2}{|c|}{ (2) Feat. $\mathrm{H2O}$} & \multicolumn{2}{|c|}{ \&. Fest, $\mathrm{H2O}$} & \multicolumn{2}{|c|}{6 Feet H20 } & \multicolumn{2}{|c|}{8 reet 120} & & & \\
\hline & & $56 \times 10^{3}$ & ESP & $100 \times 10^{3}$ & ESP & $50 \times 103$ & ESP & $50 \times 10^{3}$ & ESP & $90 x 10^{3}$ & ESP & $5 C \times 10^{3}$ & ESP & \\
\hline \multirow{5}{*}{ 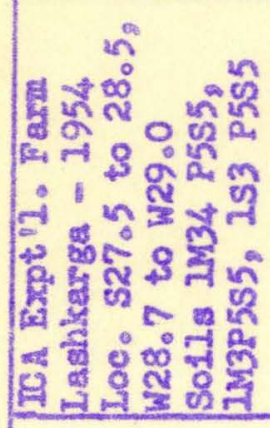 } & $1 \mathrm{Ft}$. & 53.5 & 65 & 1225 & 22 & 7,00 & 21 & 5.31 & 10 & 5.08 & 10 & 46 & $4=6$ & \\
\hline & $2 \mathrm{Ft}_{\mathrm{s}}$ & 27.2 & 58 & 118.8 & 39 & 6.04 & 36 & 4042 & 21 & 3.80 & 15 & 46 & 8 & \\
\hline & $3 \mathrm{Ft}_{\mathrm{s}}$ & 23.2 & 45 & 20.5 & 43 & 5.90 & 63 & 4.82 & 35 & 4.39 & 34 & 66 & (inc) & \\
\hline & $\angle F t_{0}$ & 8.8 & 38 & 16,3 & 12 & 8.64 & 62 & 5.04 & 37 & 4.54 & 46 & 86 & (Inc) & \\
\hline & Note: & $\begin{array}{l}\text { Whilo }] \\
\text { satiof } \\
\text { have no }\end{array}$ & $a b$. & $\begin{array}{l}\text { bility } \\
\text { ive re. } \\
\text { ive }\end{array}$ & & Iow ra & & d perme & asp & $\begin{array}{l}\text { In the } \\
\text { - equiva } \\
\text { final }\end{array}$ & al & $\begin{array}{l}\text { ts cont1 } \\
100 \text { gms } \\
\text { tion rat }\end{array}$ & $\begin{array}{l}\text { aed at } \\
\text { but see }\end{array}$ & \\
\hline \multirow{6}{*}{ 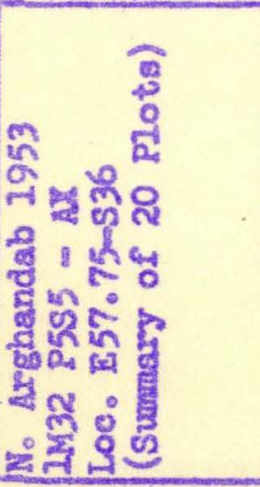 } & 1 Ft。 & 24.9 & 63 & $\frac{4.2}{8}$ & 50.0 & 4.2 & 37 & 3.2 & 40 & 9.0 & 50 & 2 & (Inc) & \\
\hline & & & & 7.8 & 24 & 2.1 & 24 & 5.9 & 27 & 7.6 & 21 & (6) & (6) & \\
\hline & 2 F. & 6.9 & 27 & $\frac{3.8}{1.2}$ & 50.0 & 4.25 & 22 & 520 & 27 & 7.0 & 32 & 2 & 4 & \\
\hline & 3 Ft。 & 3.5 & 16 & $\frac{4.2}{3.2}$ & $\frac{30.0}{25.0}$ & $\frac{6.1}{3.1}$ & $\frac{36}{(62)}$ & $\frac{5.6}{5.0}$ & $\frac{27}{17}$ & $\frac{408}{3.3}$ & $\frac{30}{13}$ & $\frac{2}{2}$ & $\frac{(6)}{6}$ & \\
\hline & & & & 32 & 20 & 3.6 & 20 & 3.7 & 19 & 325 & 22 & 2 & $(6-6)$ & \\
\hline & Note: & \multicolumn{12}{|c|}{ 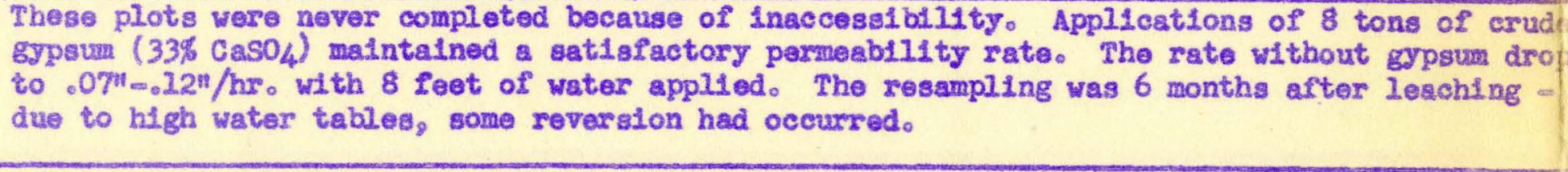 } & when \\
\hline
\end{tabular}


harmîl salts as the irrigation waters bring in. Where seline areas are to be leached the drainage waters are $11 k e l y$ to be unsuitable for remse for a number of years unless diluted by remixing with divarsion from the main supply. Analyses of drein water effluent from the Nade-1-Ali project have been made since 1953. These drains are carrying 2 to 12 tons of salt per acre-foot while the Irrigation water entering carries about $0.39 \mathrm{Ts} / \mathrm{A}_{0} \mathrm{~F}$. On $8 / 7 / 55$ a measurement of drain flow was made above the Marja bridge erossing and samples taken for anelyses. Studies from these data and irrigation water entering in Auguat Indicated 60 tons of salt ( 13 tons sodium salts) entering the project and 385 tons (210 tons of sodium salts) beling carried away dally. A large part of the

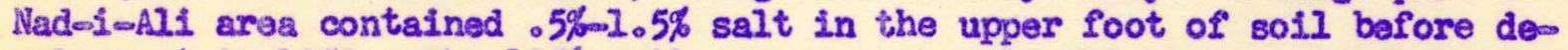
velopwent in 1952. The 1956 soll survey showed 12,500 acres relatively free of salts. Thus some improvement has occurred with a minimum of drains and a high watertable. When the farm drains have been properly installed it is expected that the rest of the area can be reduced in salts and a favorable salt balance be maintalned. That several times as much sodium salts are noving out as are coming in is a fevorable situation. It is noted also that the concentration of salts in the tile effluent has dropped about $50 \%$ since the trains were installed. (See Chart I.D 135).

2. Levels of leaching and plant tolerance. A comon mistake in reclamamtion of saline or seline-alkali solis is the sssumption that diking and adding water 1 all that is necessary. This is far from the facts if a successful job 18 to be accomplished. Solls vary from conditions which are extremely costly and difficult to reclaim to those from which excess salts can be reduced and cropping started simply by giving one heavy pre-irrigation in prepe. aration for nornal cropping. One can save time, worry and disappointment by having 211 the facts at hand before attempting to reclaim an area. A detall soil survey accompanied by laboratory anelyses and field inflitration and leaching trials will help to stablish the kinds and quantities of salts to be removed, the probable amount of water and time required for leaching and the necessity for soll anendments during the leaching process. A detall drainability survey is needed to determine the extent of drainage facilities rew quired to handle the leaching water and prevent waterlogging the erea. When the conditions pertaining to a given area have been evaluated the extent to which reclamation may be accomplished by difierent techniques may then be welghide against probable cost and returns.

8. Land drainability and reclaimablifty. Not all land can be leached and drained completely. Shallow soils over impervious materials will normally have a high watertable under irrigation regardless of how close the drains may spacod. Deep soils underlain by thick layers of silts and fine aands may continually concentrate salts at the surface by capillary movement from rather deep watertables. Since agricultutal production is the primary goal of land development, the solls in S. W. Afghanistan have been divided as I0120ws with respect to reclamation:

(1) The salt content may be reduced and malntained at low lovals and the groundwater maintained sufficlently deep below the surface that all crops climatically adapted can be grom. 


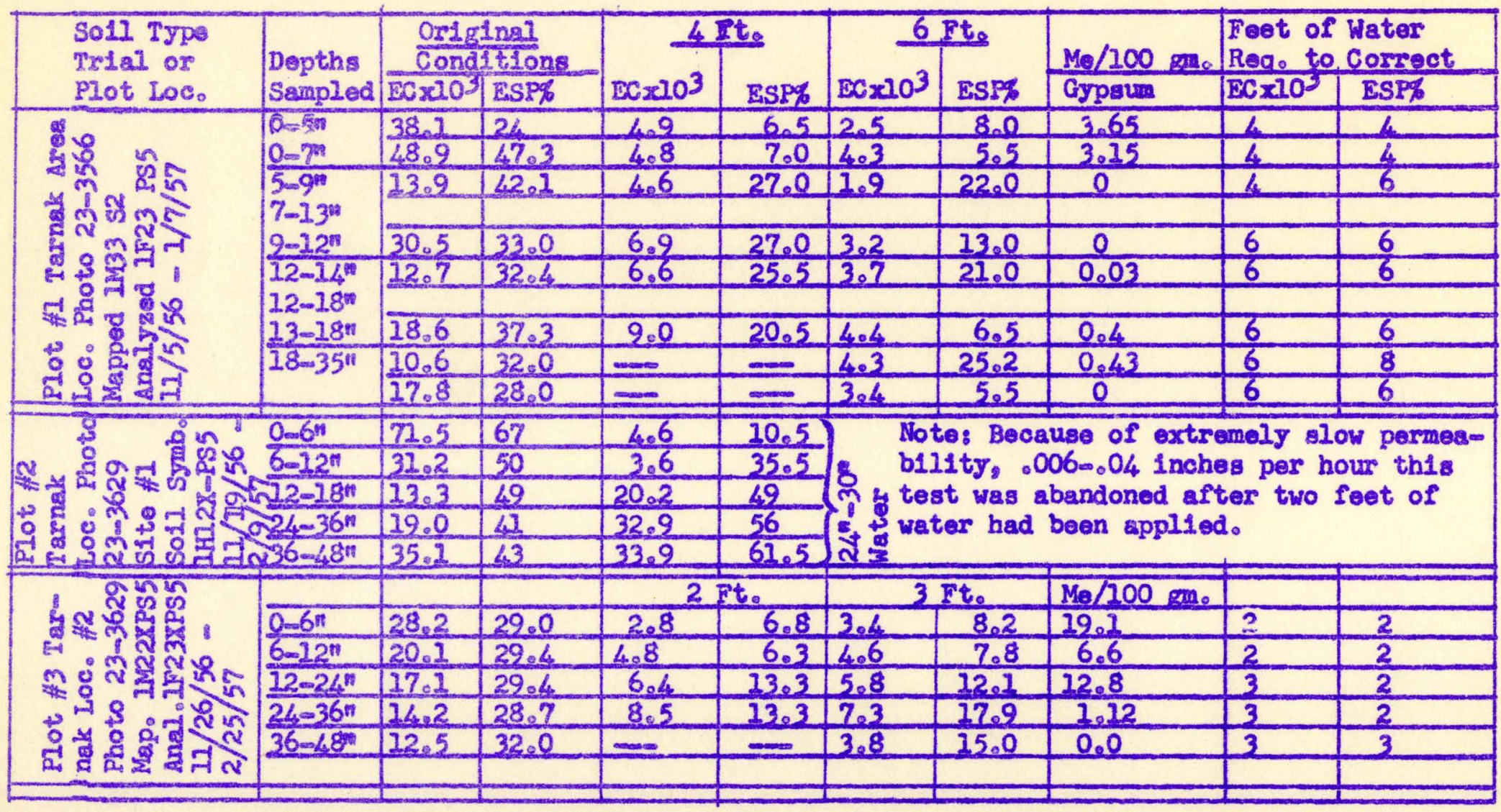


Effect of Continued Irrigation and Drainage an Sa

1.000

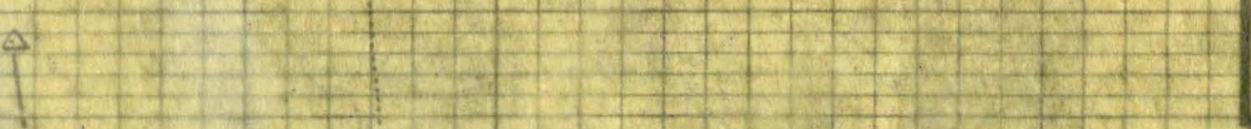

NAQ-AL AREA

DRAN WATER ANA LYEES

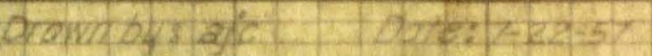

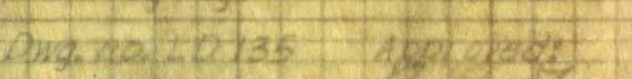

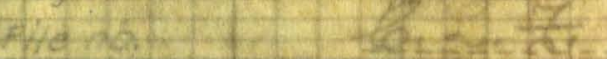


(2) The watertable may ba lowared and the sallnity and alkaIintty reduced and hold at a level pormitting good production of most of the comon field crops and the more tolorant deciduous fruits and vines.' Deep routed trees and sensitive crops may not do well.

(3) The watertable level and/or salinemalkals conditiona of the soll con be lowered and maintained at levels permitting the growth of tolerant fleld crops such as wheat and clovers. Few sengitive crops would grow well.

(4) Only crops which are very tolerant to both high watertables and salts would do well. Crops of mall grains grown in rotation with tolerant grasses and legumes would be a typical use of this group of solls.

(5) Certain conditions may pormit the growth of spocialized crops even though subsuriace dralnage might be impossible or Impractical. Certaln varioties of rice have beon grown in heavy clay solis of low parmecblility and vary poor drainability. This crop can be transplanted into \& field covered with water and kept that way during its $30-5$ month growing period. Transplanting minimizes damage to energing seedilings by salts and alkall. There is need of surface drainage to provide the slow movement of fresh water through the basins. The surface must be drained and allowed to dxy to facilltate harvest. Excess selts at the suxiace may be reduced by rom peated Ilushing and drainage. Dates have been grown on solls having 1-2\% salts and have been irrigated with sea water. Certain varieties of barley have been grown in soll solutions of $1 \%$ selts. It is possible, therefore, that conditions considered hopaless for reclanation for ordinary farming may have special uses. Generally auch lands are not recormended for present developnent in the Helmand Valley, however.

\section{ce Lesching Techniques and Procodures - Land Treatment:}

\section{i. Land Preparation.}

a. Carefully level oach basin so that no high pleces permit selts to rise by caplilarity, and to get uniform leaching.

b. Frepare broad stable dikes of $8^{m-15^{n}}$ aettled height if the solls are heavy and a long period of leaching is contemplated.

c. Deep chisel to break up hard pans or sodium pans, at the same tine mixing in gypsum, sulfur or other amendments, if needed. Sometimes natural shallow gypsum layer may be mixed with the soll by deep plowing. This would hesten infiltration and is especially helpful if the topsoll is alkaline but the next layer has excess gypsum.

d. Solls of high clay and calcium content and of slow pormeabilsty should be alternately leached $\left(1^{\prime} \mathrm{m}-2^{\circ}\right.$ of water) and allowed to thoroughly dry and crack. Such soils should not be plowed when wet.

2. Application of leaching water.

8. The water should preferably be low In sodium salts but contain 
ample anounts of calcium salts which would promote soll structure, remove alkail and improve permeability. Soils of naturally good permeability affected oniy by normal salts do not need the high calelum water. Finely ground gypsum if needed can be introduced into the 1rrigation water at the head gate nearest the block to be leached or mey be mised Into the soll as in 1 (c) above.

b. The amounts of leaching water required and the time required to losch vary widely with the soll texture, sodivm saturation percentage, permea bility, presance or absance of high salts and gypsum and the rate at which groundwater can be removed. A test plot on the Seraj leached with two feet of water and required only 3-4 days. Another test plot in the Tarnak required 8 feet of water and 90 days of application. In the Tarnak leaching experiment the use of Arghandab water alone was enough to reclain the land to a point where cropping could begin. The grpsum did ald in lowering the alkali and maintained a more open soll, however. Since bnly the construction of basins and application of leaching water over periods of $1-3$ months is all that is necessary to prepare the land for its first crop, assuming installation of drains, it does not appear that this program is beyond the abilities and resources of most gettlers when given proper guldance. Where alkall conditions appear, they nay be improved by gypsum which is commonly locally available. In extrene cases several years of alternate lesching and drying and growth of reclamation crops is necessary. The polders of the Netherlands are said to require $8-10$ years before they are safely reclained from the sea to crop production.

Table 47 shows the results of severel leaching trials in the Helmand Valley. Reasonable initial reclanation of some rather difficult soils was accomplished without gypsum and without artificial drainage. It must be pointed out, however, that drainage and careful irrigation to control groundwater levels is an essential part of mointaining and continuing to use these reclaimed lands.

The U.S.D.Ao Salinity Laboratory has stated that soils which can transtrit water continuousiy at $0.04^{n}$ per hour or higher can be reclatmed. Table 48 summarizes water intake rates from infiltration, leaching and Irrigation trials of S. W. Afghanistan solls. Over 250 casas are 1neluded. The data show that some high sodium elays and silty clays fell below this level but 211 other tex tures remained sufilelently permeable for reclanstion with or without gypsux. Losching roquired from as Iou as 24 hours to 570 hourso A heavy silty clay soll of the Tarnak dropped to $.006^{n}-04^{n}$ per hour on lesching. Such a soll is not recontuended for use.

c. As long as the rate of Intake stays above ..2\%/hro (.25ec) leachIng should be continued. If the rate drops below this it is advisable to discontime leaching, allow the soil to thoroughly dry and crack and if possible chisel deeply bofore resuming leaching.

do Boron in Solls. Solls tested In several of the project areas were found to contain soluble boron salts. Boron 1 s essential for plant growth In minute quant1tios but becomes torcic to some crops when in concentrations anounting to 3 parts per willion or highes。 Relative tolerances to boron are not wall astabis shedo 
TABLE 48

\section{FIELD STUDTES OF WATER INTAKE RATES OF $S$, W AFGHANISTAN SOILS}

\begin{tabular}{|c|c|c|c|c|c|c|c|}
\hline \multirow{3}{*}{$\begin{array}{l}\text { Group } \\
\text { (Textural) }\end{array}$} & \multirow{3}{*}{$\begin{array}{l}\text { Textures } \\
\text { Included }\end{array}$} & \multicolumn{2}{|c|}{ Horma $5017 \mathrm{~s}$ IL } & \multicolumn{4}{|c|}{ High sodiun Solls $2 /$} \\
\hline & & \multirow{2}{*}{ Meas } & \multirow{2}{*}{$\begin{array}{l}\text { Mean } \\
\text { Final } 6 /\end{array}$} & \multicolumn{2}{|c|}{ W3 th Grosum 32} & \multicolumn{2}{|c|}{ L Without Grogum 4 C } \\
\hline & & & & Mean Initial & Man Final & Mean Injtigi & Mean Fino \\
\hline $\begin{array}{l}\text { Modo } \\
\text { Coarse } \\
\text { pextured y } \\
(36)\end{array}$ & $\begin{array}{l}\text { Loamy Sands } \\
\text { to } \\
\text { Sandy Loame }\end{array}$ & 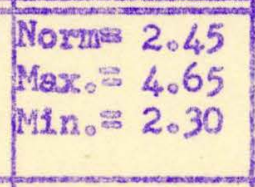 & $\begin{array}{l}\text { Norm }=1.00 \\
\text { Max。①.84 } \\
\text { Min。.2.5\% }\end{array}$ & No & Dats & & \\
\hline $\begin{array}{l}\text { Yed. } \\
\text { Textured } \\
\text { Soils } \\
(144)\end{array}$ & $\begin{array}{l}\text { Loens, } \\
\text { Sandy clay } \\
\text { loams, } \\
\text { Ssit loans }\end{array}$ & $\begin{array}{l}\text { Norma2.15 } \\
\text { Max.93.65 } \\
\text { Min。=0.95 }\end{array}$ & $\begin{array}{l}\text { Norma } 0.45 \\
M 2 x_{0}=1.50 \\
M 1 n_{0}=0.25\end{array}$ & $\begin{array}{l}\text { Norm=2.15 } \\
\text { Max }_{0}=2.25 \\
\text { Minow0.60 }\end{array}$ & $\begin{array}{l}\text { Norm }=0.30 \\
\text { Max }=2.75 \\
M 1 n_{0} \equiv 0.04\end{array}$ & $\begin{array}{l}\text { Norws: } 1.00 \\
\text { Max. }=2.50 \\
\text { Min。 }=0.60\end{array}$ & $\begin{array}{l}\text { Norm }=0.15 \\
M_{0}=0.25 \\
M n_{0}=0.04\end{array}$ \\
\hline $\begin{array}{l}\text { Mod. } \\
\text { Heavy } \\
\text { Textured } \\
(62)\end{array}$ & $\begin{array}{l}\text { Clay loans, } \\
\text { Silty Clay } \\
\text { looms }\end{array}$ & $\begin{array}{l}\text { Morm: } 1.55 \\
\text { Max. } \approx 3.25 \\
\text { Min. } \approx 0.60\end{array}$ & $\begin{array}{l}\text { Normo.28 } \\
\text { Max。0.65 } \\
\text { Min。0.38 }\end{array}$ & $\begin{array}{l}\text { Norma2. } 15 \\
\operatorname{Max}_{0}=2,00 \\
M n_{0}=0,60\end{array}$ & $\begin{array}{l}\text { Norrn }=0.20 \\
M_{0} \approx 0.55 \\
M i n, \approx 0.06\end{array}$ & 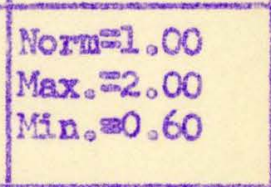 & $\begin{array}{l}\text { Norm }=0.10 \\
\operatorname{Max} \approx 0.19 \\
\text { Min, } \approx 0.05\end{array}$ \\
\hline $\begin{array}{l}\text { Heavy } \\
\text { rextured } \\
\text { Solls } \\
\text { (2L) }\end{array}$ & $\begin{array}{l}\text { Silty Cisys } \\
\text { to } \\
\text { C.ays }\end{array}$ & & $=\infty$ & $\begin{array}{l}\text { Norm=0.75 } \\
\text { Max。=1. } 50 \\
\text { Min. }=0.70\end{array}$ & $\begin{array}{l}\text { Norme0.06 } \\
\text { Max. }=0.20 \\
\text { Min。=0.03 }\end{array}$ & $\begin{array}{l}\text { Norm } 1.50 \\
\text { Max. } 1.2 .00 \\
\text { Min。 } \equiv 0.50\end{array}$ & $\begin{array}{l}\text { Norm }=0.04 \\
\operatorname{Max}_{0}=0.09 \\
\operatorname{Min}_{0}=0.02\end{array}$ \\
\hline
\end{tabular}

Footnotes: Data is taken from doublewing infiltration tests, besin leaching trials and frrigation trials.

I Noxral solls contelning genorally less than $15 \%$ exchangeable sodiuno

2) Contalning more than $15 \%$ exchangeable sodiuta

3/ Gypsum added or present in falr to high quentities.

Lf Genarally no gypsum added o may or may not be present in 3011 .

5 Rats during first few minutes to ane hour.

Steady rate achieved after several hours mun.

Nunbers in parentheses indicate the number of testis or corbinations of tests used 1. computing the velues given in the table. 
Experiments in the Coachalla Valloy, Californta (Reeves otal, Hilgardis Vol. 24s Sept. 1955) showed that oats began to be affected around 5 ppm and were reduced $50 \%$ in yields at $15 \mathrm{ppm}$. Anelyses of solls in the Shamalan Valley which ware heavily infested with serub salt cedar (Temarix gallica, T. [IIspida and others) ran as high ss 100-120 parts per million of boron. Shown below is the distribution of boron in various Helmand Valley solls as compared to the relative tolorance of cownon afghan crops interpreted from analyses and fleld observations.

Tablo 49

Boron Content of Solls Tested

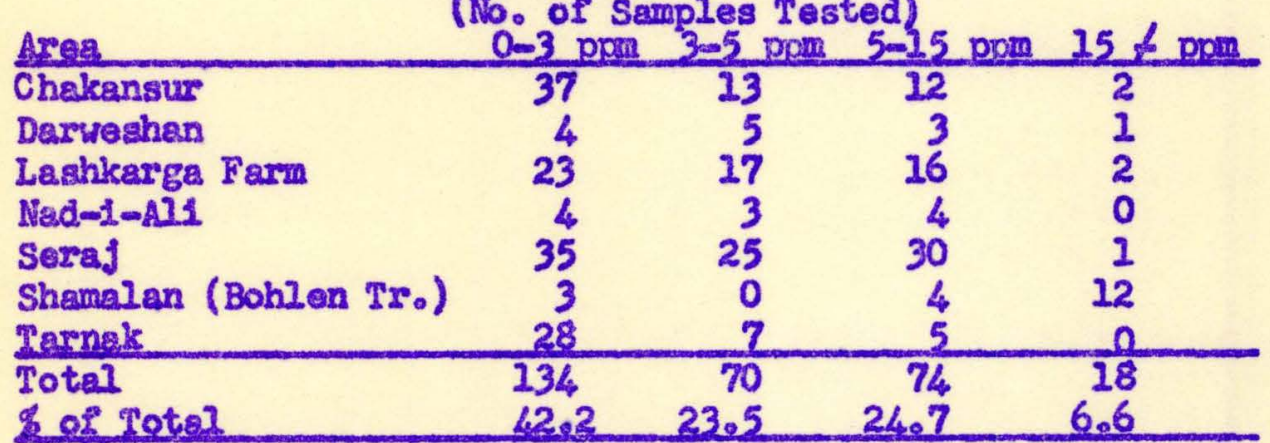

Relative Plant Tolorance to Bogon Salts

\begin{tabular}{|c|c|c|}
\hline Tolerant. & Sens-Tolexant & Senstive \\
\hline $100 \mathrm{pom}$ & $18 \mathrm{prm}$ & $5 \mathrm{prm}$ \\
\hline Athol (temarix gall1ca) & Sunhoung & Walnut \\
\hline Ghas (tamex 1x aphyl1a) & Cotton & Garden Peas \\
\hline Toona C1liata & Tomato & Snap Beans \\
\hline Asparagus & Navy Bean & PIun \\
\hline Date Paln & Barley & Apple \\
\hline Berruda Grass & Wheat & Grape \\
\hline Tal1 Wheat Gsass & Sudan & FIB \\
\hline Beets & MIIO & Pesch \\
\hline Alfalfa & Guar. & Apriscot \\
\hline Melons & Corn & Orange \\
\hline Tall Fascuo & Oets $-(15)$ & \\
\hline Clovers & Prupiefn & \\
\hline Egg Plant & Squash & \\
\hline Broad Bean & Ponegranate & \\
\hline Onion & Flold Beans & \\
\hline Lettuce & Peppers & \\
\hline Carrot & Swoet Potato. & \\
\hline 18 & 6 & $3 \mathrm{ppm}$ \\
\hline
\end{tabular}

Dpper plants most tolerant in each colvan, lowest least tolerant。 Concentrations in parts par million estirested roughly to cut growth or ylelds 50\%. This is based on very inadequate date and can only be a general guide as to crop gelection. 
Leaching trials Indieate that boron solts move out of the soll during leachIng slower than do the noxtal salts which oceur in saline lands. For this reason areas containing high boron nayy noed $1-3^{\prime}$ more water than nornal for the leach Ing process. Tests at Lashkexga Farm plots showed that soils with an average of 16.6 ppa boron (range of $904=2 \%, 0$ ) had after 6 feet of loaching water an average of 2.7 ppon in the 1st foot and 409 in the second foot (range of 2.00402 and 1.5 9.5. Pespectively). After 8 leet of water the first loot averaged the same but the 2nd foot average was reduced to 3.9 with a range of $2.206 .0 \mathrm{ppm}$ 。

The following graph is inserted to show the behavlour of one group of solls on leaching. Soluble selts move out quiekly so that I foot of water per foot of soll is normally adeçuate. The exchangeable sodium percentage dropped less rapidly in the first two feet and sometimes increased in the 2nd and fourth feet。 To reduce the first two feet to a safe level required 8 feet of water or 4 feet per foot. Boron was lowered at about the same ratio as exchangeable sodium, 1.0, , $30-4$ feet of water per loot of soil was required.

\section{$\mathrm{d}_{0}$ - Gropping and use of Saline Lands:}

1. Initial Cropping. One does not have to watt until the salts are reducod to less than 4 millimhos conductivity and to a sodium percentage less than $15 \%$ and to a pH less than 8.5 - all desirable levels - before beginning to grow crops. As a natter of fact growing certain crops hastens the reclamation, improves the soil and brings some returns to the farmer during the reclamation period. Some of the plants which may bo grown are?

a. Early stages with high salts and alkal1 - atriplex (saltbrush), cyperus laevigatus (saltreed), cynodon dactylon (Bormuda grass) or any other im ported or local plant that will grow. This adds organic matter and opens up the soli by root channela. The fleshy leafed saltbush plant renoves condiderable salts in the plant foliage if harvested and carried off the lando

b. After the flrst heavy salt concentration is removed, such crops as barleys bermude grass, tell wheatgrass or any crops that will permit the application of large amounts of water can be grown. Rice is especially good for this purpose since a very vesful and highiy prized grain crop can be grown while the land is being lesched. However, since rice requires $3-5$ months of inundation, solis of even $.04 \mathrm{~m} / \mathrm{hr}$. Infiltration rate can percolate 7 to 12 feet of water. This crop only needs be grown for reclamation purposes on the deeper, heavler solls of slow permeability. Ries will grow bottex if the soll contains excess quentities of gypsum or gypum is added. erops can be grown:

c. After the saits and alkali are reducod to where soll building

(2) If atill affected by high watertables, use strawberry clovar, trifolinu alexandxium, birdssoot trefoll, sunhemp or any soil building erops tolerant to saline-alkali conditions and high groundwater. 

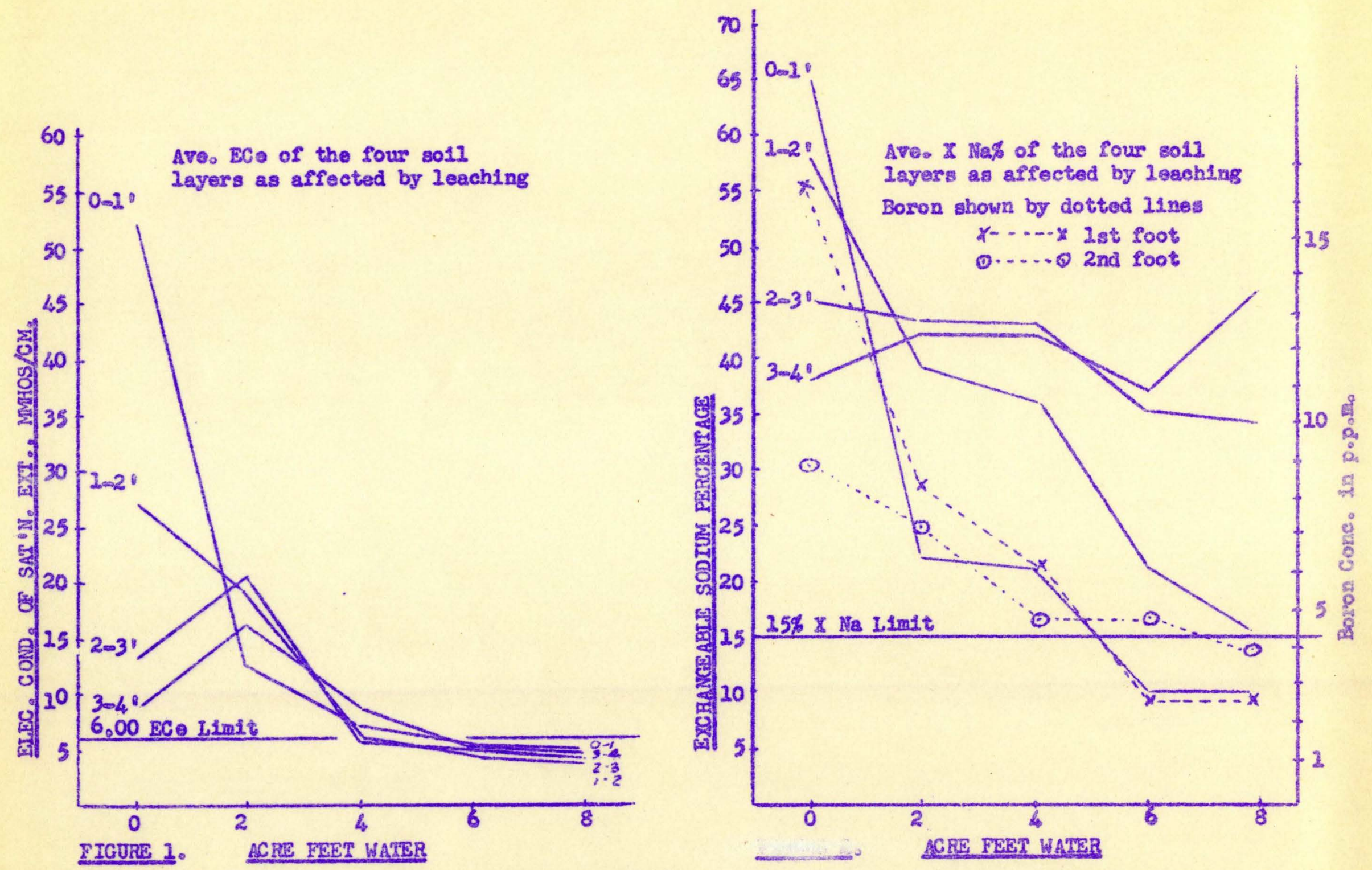

ICA RECLAMATION PLOTS AT FOA DEMONSTRATION FARY LASHKART BAZAAR 


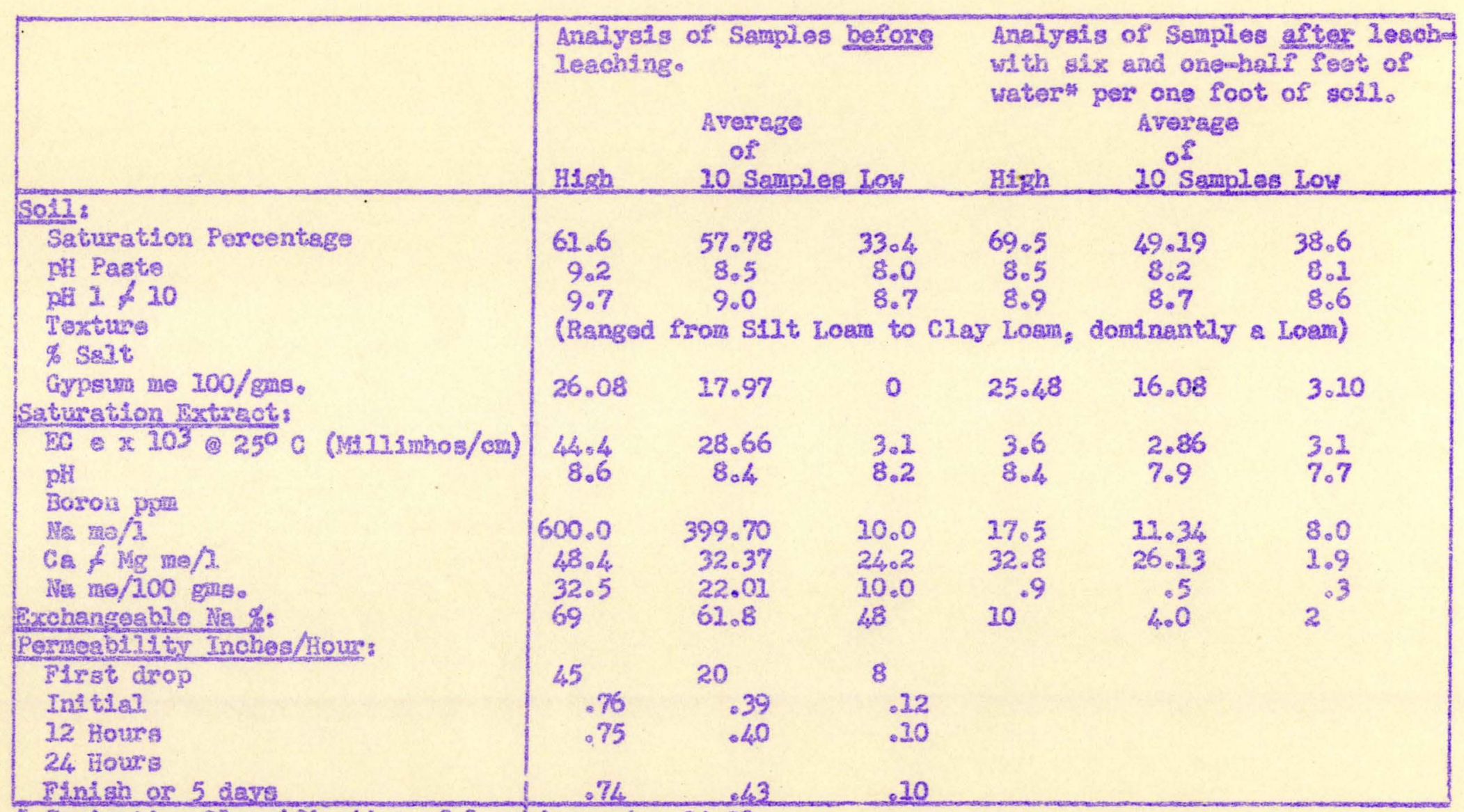

Trugation Classifieation of Iegching water c4mse. 
(2) If watertable recedes, grow sweet clover, alfalfa, vetch, sesbania, guar or similar crops. The purpose of these crops is to provide organle matter for soll conditloning and to add nitrogen to the soli. If avaliable, barnyard manures and chemicel fertilizers should be used. The soll will be low in soluble nutrients following heavy leschings and the use of high phosphate fertilizers of foli to low nitrogen content will greatly stimulate the growth of green manure crops. Such erops should be turned under at lush growth to promoto rapid decay and soll improvernent.

2. Regular Cropping. Once the common fleld crops can be satisfectorliy grown a regular rotation should be selected for the land. The erops which can be grown in South Afghanistan are arranged in the following table in order of their relative salt tolerance. The laboratory analyses for this projoct show the kinds and amounts of selts and alkall found. (Table 51)

In all cases it should be determined at what levels salinity, alkalinity and watertables can be reduced and maintained. If good drainage and complete removal of toxic saline-2lkall conditions proves too difficult and costly a lesser degree of reclamation may bo found desirablo. In any case the crops selected should be those of the highest productivity and income value for the conditions to bo maintalned.

\section{$\theta_{0}=$ Other Practices Used on Salino-Alkall Solis:}

2. Other practices which may be usefur, depending on the success of leach ing and conditions of the soll, includer

a. Selection and growth of salt and water tolerant plants in accordance with the extent of reclamation achieved and maintainsble. Callfornia Mariout barley which is adapted here has been shown to yield $80 \%$ even at 13 -16 who/an conductivity provided germination was alded by keeping the ground molst and the salt concentration bolow 5000 ppa in the soll extract.

b. Seeding on molst soll and keeping solil molst until emergence (using light frequent wottings)。

c. Using surface mulches of straw or manure to aid seedling ernergence and prevent crusting.

d. Using cover crops to shade ground durlng emergence of fine seeds 1.60 , whest with alfalis.

B. Using large seads that produce strong aeedlings and emerge oasily to plant with soeds which have difficulty in emerging.

P. Arolding sealding plants by hot weather leaching.

2. Loo2 Practices Used. The APghans have learned by oxperlence many ways to grow crops in seline-2lkali soils although they ghow very little understanding of the use of subsurface draingge 
It is a combon occurence to find fazwers, who bave gome dependeble souree of water, xaising crops of grain in the nidst of extremely salinewalkali areas.

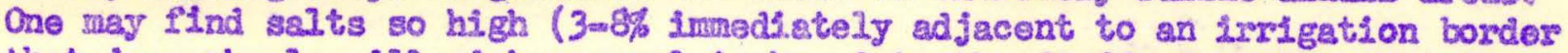
that jeep wheels will sink several Inches into the fluffy topsoli. Yet the laboratory tests on solls inside the wheat flelds ahow normal?y no nore than slight $(.1-02 \%$ to moderate $.2-3 \%$ ) arlinity and comparable alkalinity. One flinds also evidences of abandonwent on a large scele. However, this may have been caused by a fafluxe of water supply or other reasons as well as by waterlogging and salinizing of the so11.

Thelr auccess in growing melons, squash, cucumbers, grapas and other erops adjacent to raised bods is illustrated in the sketch of salt movement (Chart LD 136 ) Careful location of the seed or cuttings avolds those zones where selts will accumulate. While this may not permit full cultivation of all the land and is not a permaneat subst Ltute for reclamation by leaching and drainage, It does point out that presently highly salino-alkali areas are not necessarily useless wasteland and may, when and if a dependable water supply is made avail able, be subjested to some use.

By the Helmand Valley solis and drainability surveys $5 / 6$ of all salinom alkall lands have been found clessed as not recommended for reclamation. About 1/6 were deferred for future reclamstion the areas having been cerefully sel. ectød for suitable subsoll permosbility and substratum drainability. Such areas commonly occur interspersed with the presently irrigable landso

The precaution was taken to provide a olassiflcation showing first, those lands that can bo used now, and second, those lands that are suitable for use when reclaimed and show promise of feasible reclamation. Those lands which will be very difficult or slow to reclain were pleced in the general category of unsuituble lands along with definitely non-irrigable types such as graveliy or stony solls and sand dunes. Some of these lands are being farmed in small patches as described above. It is felt, however, that such lands do not justify consideration as project lands at this time and, unless population pressure becomes much greater than now, may nover warrant expendituxes of public funds for thelr reclemetion and development.

As to the diffleulty and costs of reclanation of the selected lands, careful differentiation must be made between an alkali soll, and saline to saline-alkali conditions found in the soils selected. The principal factors affecting reclamation as stated above are soll permeability and substratum drainability. As long as a soll in place transmits water (the U.S.D.A. Sallnity Laboratory, agys continuous transmittal of 0.04 inches/hro will allow declanation) vertically and laterally and excess water can be renoved by dralns, even seriously saline-alkali solis can be reclaimed. Whether spectal soll anendments are required to maintain permeability and keep the pH bolow toxic levels (gonerally below pH 8.7 in the saturation extract) depends a great deal on the nethods used and the original gypsum and the lime content of the soll.

Solls clasafied as suitable for reclemation in Afghanistan generelly have a basic water trangmittal rate of over 0,1 inches per hour and have moderately falr or better aubsurface drelnage. 


\section{BED AND FURROW IRRIGATION OF SALINE SOILS}

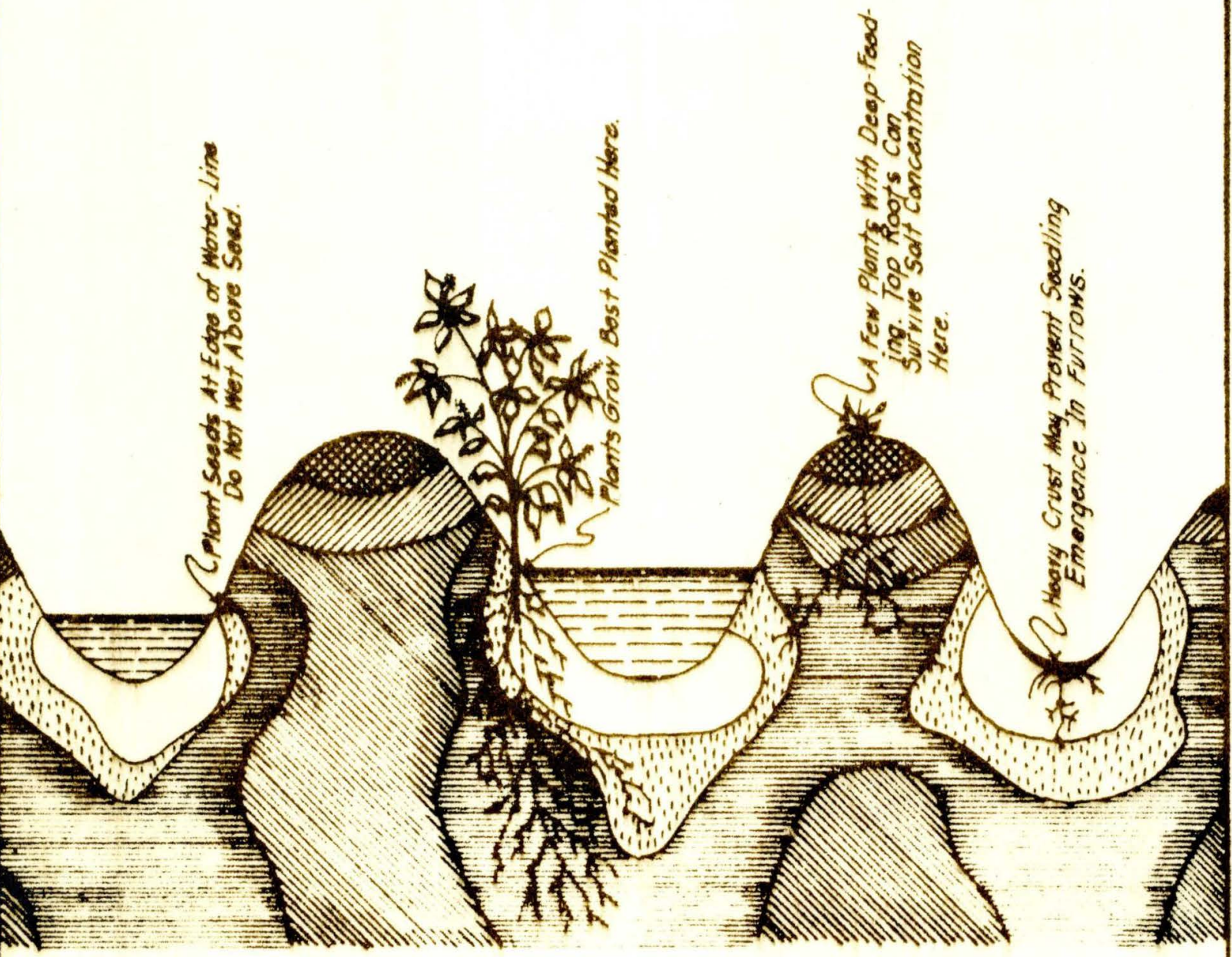

AN ILLUSTRATION OF SALT MOVEMENT IN IRRIGATED RIDGES \& FURROWS

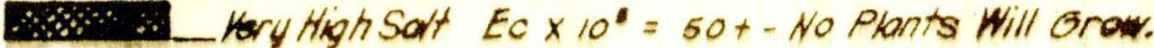

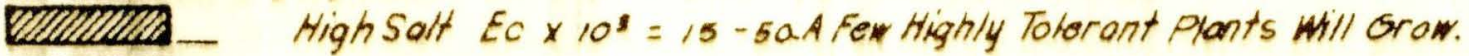

Hod High Salt EC $\times 10^{3}=-15$. Tolorant Plons will Grow.

-... Lad Solt EC $\times 10^{\prime \prime}=4$ - Most Common Craps will Grow.

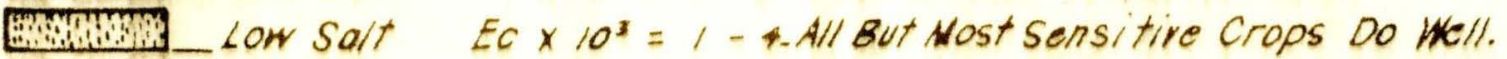

very Low Solt EC $\times 10^{2}=\langle 1$. All Crops will Grow Well. 
Ix. sost eases those solls contain enough natural gygoum and 1 mo to materlally asmit In reductng the exchangeable sodfum parcontage to safe levels.

These solis have show by actual leachlng trials that in most cases tho salts, exchangeable sodium and boron can be satisfactorily reduced to where cropping can begin without adding sulfur, gypsun or other special amencinenti. Where one or more years of crops must bo deforred or if low yilelds occur duro Ing the reclanation process, the government may provide some assiatance in the form of subsidies or other incentivas。

4. Hind Frosion Control. The possible effect of winds on water use by plants was discussed in Chapter II, and average wind veloclties for several stations are given in Table 6. Wind velocities for the period, June-September, appaar much higher in the Chakansur Area than in the desert and upper valley projects. Wind movement as a soll forming agency was discussed briefly in Chapter IV.

Wind erosion is a serlous hazard in the developnent of certain paxts of the Marja, Shamelan, Darweshan, Garmsel, and Chakansur Areas. Drifting sand on the ground surfise produoes small humbocs around desert shrubs and bunch grasses. Small dunes occur scattered over the surface of otherwise irrigated solls. Large active dunes and spersely covered sand hills occus to the windward side of altes for structures in the central and lower Darweshan, So. Marja and So. Shamalan. The generel direction of sand drift is S. E。 In the Chakansur, east in the Garmsel and east to slightly N.E. in the upper Holmand Valloy。 Countering winds partially reverse and hold in check the general movement. Stretches of loose sands which occur on the windward side threaten the $11 f e$ and usefulness of strucm tures. Considerable cleanout of deep drains on the Harys has been caused by drifting sands. On the east break of the Darweshan terrace are numerous patehes of loose drifting sands and anes to which the abrupt slope offers some obstruction and control.

The menace of drifting sand during periods of strong winds which are con mon to the lower areas is threefold: (1) filling of ditches and drains ereatIng an annusl high cleanout cost; (2) damage to young and growing cropis by physical danage including a dessicating effect and smothering of plants; and (3) a source of discomfort and unhesithy living conditions for gettlers and for other people working in the area.

Erosion control measures which may be required in these areas are of three general types: (1) temporary or energency measures to be applied duxing the construction and land development phases; (2) permanant wind erosion control practices and measures; and (3) anmul field control practices.

\section{a. Temporasy or Emergeney Wind Erosion Control:}

(1) Start land development on the winduard side - If the general drift of sand is north eastward this would mean starting on the firat block of land west and south of the sand drifts. This would protect the main outlet drain from drift and give protection to the next land block。

(2) Listing or deep plowing - Where suitable soils occur tracts to the windward of irrigable lands can be ridged in parallel high ridges and deep furrows normal to the prevaliling direction of sand drift. Loose sands will catch in these barriers and be held against drifting unt1l the furrows are nearly filled. 
Ridges made 10-20 meters apart with a 2-foot moldboard or lister on a D-7 or D-8 w111 give a lot of protection to the area. Later if necessary another series of ridges could be made between these. Th1s is an expensive procedure but may be required to faclititate land developwent and help in establishing protective shelter belts. Some tracts inside the projects may require similar treatment.

(3) Mulching of dunes - In places mall dunes which are barren or only partially stabilized by small shrubs and grasses lie on or along-side tracts of Irrigable land and are a hazard to land developmento Where possible, the smaller ones should be spread out over the imrigable lands in the leveling process and plowed under with a laxge moldboard plow. Careful study of texn tural grades and depths is necessary to insure good usable land after plowing and smoothing. (Søe F1gree 2 sor deep plowing speciflcations). Deep plowing to turn under sands tand bring up surface soll of finer texture has been profitable in trials made in the states and has achieved effective wind arosion control. Where impractical to level, these dunes may be temporarily stabilized by spreading straw or brush $2^{\prime \prime}-4^{n}$ deep over the surface and anchoring it by packing with a sheeps-foot roller. Seeding of sand stabilizing grasses and forbs should be made in the mulch just ahead of the winter rains. Where practical, plantings of shrubs, grasses and trees should be made on the windward side of active dunes early in project developmento

\section{b. Permanent or Long-rime Wind Frosion Control Measures:}

(1) Range Control - Observation of range cover in the lower Helmand and Chakansur Areas show a mumber of grasses and shrubs capable of growing on deep sands or on sandy solls. Eight species of grass, 5 different shrubs and several annual and perennial forbs were found on a single field trip over sand areas in the Chakansur, near Yakchal, in the Shamalan and in the West Marja areas. Complete restriction of grazing or use for fuel in these areas would allow the plants to remseed and allow the maximum accumulation of vegetative growth for wind erosion control. Artificial seeding and planting of indigenous shrubs and grasses should be undertaken on the more barren axeas. Other sand stabilizing plants could be brought in and Increased by seeding and transplanting methods。 Complete restriction of grazing and harvesting for fuel, and a system of range improvement will probably be the most economical and beneficial of any control measures which can be devised for protection of irrigated lands from sand encroachment. Areas of sufficient size should be declared public domain, and grazing and fuel harvesting prohibited until control of drifting sands could be established. Strict regulation would be necessary afterwards to prevent deterioration of the protective cover。

(2) Tree Windbreaks or Shelter Belts: - Essential to control of drifting soil and to protection of growing crops from hot winds as well as sands is a complete system of windbreak tree and shrub plantings throughout each prom ject and on its windward perimeter. Russel K. Smith, FOA Forester, studied species adapted to the area and made recommendations which were included in the Supplementary Project "Afforestation Program", September 6, 1953, and in his "Report on Afforestation in Helmand Valley", October, 1953. C. W. Corson gave an extensive list of usable species in his August, 1956 Report on the Forestation Program (ICA)。 In these reports a mumber of adapted species were recomnended from which various planting combinations can be made. In addition the mmerous local shrubs which appear to grow on sands under natural environment should be seleeted and used in windbelts for checking and holding sands。 
(PRACTICE S-5) SPECIFTCATIONS FOR TURNING UNDER S.ND DEPOSITC (ACP-S,C,S, SPQCIFICATIONS - FLOOD RECLABAATION, 1951-1.952)

(DEPOSITS MUST BE COARSER THAN FINE SAND. AT LEAST $8 "$ OF OLD SOIL, FINER THAN FINE SAND, MUST BE PIACED ON TOP BI PLOWING)

- Figure 1. Mintmur Plowing depths in Inches.

\begin{tabular}{|c|c|c|c|c|c|c|c|c|c|c|c|c|c|}
\hline $\begin{array}{c}\text { Texture } \\
\text { of }\end{array}$ & & & & & TH $\mathrm{O}$ & SAND & COVES & NG IN & $\mathrm{INCH}$ & & & & \\
\hline $\begin{array}{l}\text { Underlying } \\
\text { Sold }\end{array}$ & $4^{n}$ & $6 n$ & $9^{\prime \prime}$ & $12^{11}$ & $25^{\prime \prime}$ & $28^{\prime \prime}$ & $22^{\prime \prime}$ & $24{ }^{\prime \prime}$ & $27^{\prime \prime}$ & $30^{\prime \prime}$ & 33 & 36 & 39 \\
\hline Heavy $(\mathrm{H})$ & $12 *$ & $H_{6} \neq *$ & $27 * *$ & 20 & 24 & 28 & 32 & 36 & 40 & 48 & 56 & 64 & - \\
\hline $\begin{array}{l}\text { Moderately } \\
\text { Heavy }(\mathrm{F})\end{array}$ & 12 & $u_{4}$ & 37 & 22 & 27 & 32 & 36 & 40 & 48 & 54 & 60 & - & - \\
\hline Mediun (M) & 12 & 14 & 38 & 24 & 30 & 36 & 42 & 48 & 54 & 60 & - & - & - \\
\hline $\begin{array}{l}\text { Moderately } \\
\text { Light (S) }\end{array}$ & 12 & 14 & 21 & 28 & 35 & 42 & 49 & 60 & - & - & - & - & - \\
\hline Light (I) * & 12 & 28 & 27 & 36 & 45 & 54 & 63 & $\infty$ & $\infty$ & - & - & - & $=$ \\
\hline
\end{tabular}

Coarse $(C)$ * *Plowlng less than $22^{\prime \prime}$ deep not recommended; nor is plowing recommended where texture of underlying soil is coarser than loamy fine sand. **At least $8 "$ of old soil must be turned to provide adequate thickness of soil for a seedbed and for tillage operations.

Figure 2. Maximu practical depths in inches of sand plowable by moldboard type plows of deslgnated size.

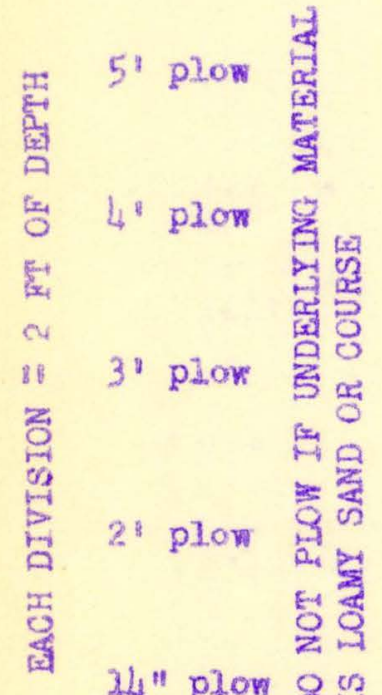

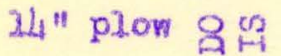

P3ow

Bottom

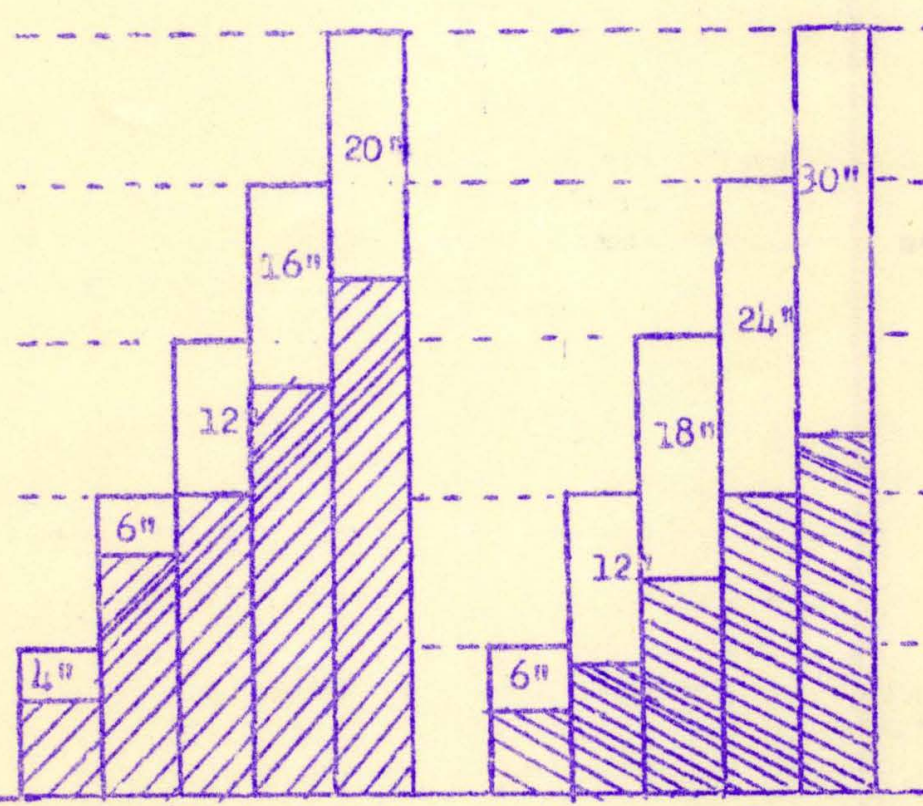

Coarse (C) to Light Textured (1.) solis
Medium to moderately sandy (M\&S) soils

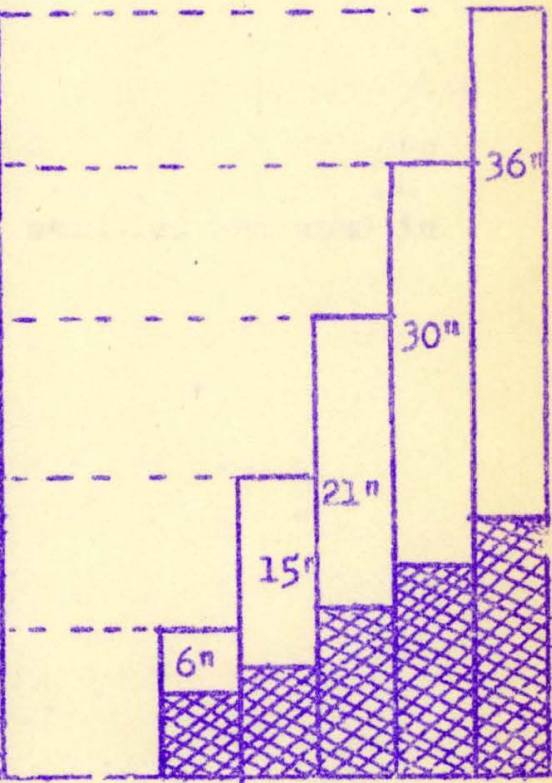

Moderately heavy to heavy (F\&H) soils

Prepared by: Claude L. Fly - Stat e Soil Scientist 
The type of plantings which ean be made Include:

(a) Woodlands. Areas of Class IV and V lands would afford woodland areas of sowe use. The recent alluvial soils could be adapted to this purpose. Woodlot plantings such as recommended by Russel $\mathrm{K}$. Smith should be used.

(b) Perimeter Windbelts are needed on the windward side of large areas. If strips 70 to 100 meters wide could be utilized, several shelter belt strips with intervening spaces would serve to afford protection of irrigated lands.

(c) Sand pune Stablilyation Plantings of local shrubs and grasses found to do well on the sands should be planted on and axound dunes which are so large as to be ineconomical to level and plow uxder. Where farm ditch and border waste water can be used, plantings of trees and shrubs around the margins of dunes w111 help to check drffting and allow local gxasses and shrubs to establish themselves on the edges of the sand ridges. The hay method of seeding gxasses should be used; 1.e., hay cut at maturity of seed should be spread over the dunes and packed with a sheeps-ioot roller as described above. A layer of mulch (hay, straw and brush) $2^{\text {"Nol" }}$ thick will, when so packed, effecifvely holdsthe sand in place until seedlings have a chance to establish themselves. Every effort should be made to procure seeds and seed hay of sand grasoses during a season when they have made abundant and viable seed production. Seed plots and cuttings from sandiemadapted shrubs should be started so as to prom vide planting materials needed for January to March plantings. Protection of these areas from grazing and fuel harvesting is essential to establiahing and maintaining protective cover, and preventing the danger that the sands may become unstable and start drifting into irrigation and drainage ditches and into Ilelds where they will seriously interfere with cultivation and may smother or kill growing crops.

(d) Project Shelter Belts of 3 to 5 rows of trees and shrubs should be planted in areas subject to high winds in hot summer months, to the west of northsouth laterals and sublaterals and to the south or north (Chakansur) of eastwest laterals and sublaterals. This will give growing crops protection from the westerly and southwesterly winds which are most damaging in the area. Five row belts are preferred along main lines while two and three-row belts may be used elsewhere. Spacing under Irrigation may be in rows 2 meters apert with trees planted 2 meters and shrubs I meter apart in the rows. Plantings should be staggered between rows so as to present a solid front toward the winds. All plantings should be at least 5 irrigation borders (120') windward of the irrigas tion ditch or deep drain protected so that sand drifts passing through the belt may not drop directly into the ditch but can be disposed of by leveling and deep plowing or other means. All plantings must be planned and laid out so as to least interfore with project irrigation and orrinage structures, particularly with tile drains.

(e) Individual farm plantings may be needed to give complete protection. The plantings may afford protection at farm intervals of $220,440,660$, or 880 feet with the closer spacings being on the sandier, more erosive solls. The distance between wind barriers may be further shortened by single jows of trees on farr boundaries in a north-south or east-west direction. Low-growing fruit or nut trees or a combination of shrubs and Internediate trees could be used.

As projects become older and permanent orchards, vineyards and village plantings become well established changes in spacing of tree belts by elimination of some of the closer spaced tree rows may be made. In many places there 
is a large proportion of Class $V$ lands around and in a project area. These lands should be utilized as Euch as possible for windbreak plantings and for fuel production. In places it will be necessary to use lands of irrigable classes to insure satisfactory tree belts in the proper locations. If/water table develops, the tree rows may draw a considerable portion of their water requirement from farm Irrigation and ditch percolation losses rather than from direct irrigation. Such transpiration may in turn help to lower the trater table.

\section{c. Annual or Farm Wind Erosion Control Practices:}

Annual or farn wind erosion control practices should be scrupulously adherod to as wind erosion can do considerable damage in a short time. One uneontrolled fleld can quickly block a main lateral with sand and cause damage to erops below this polnt by cutting off the water supply. Drifting sand mothers, desicates and physically damages young plants. Since irrigation water w11l be avallable at all seasons of the year, a few simple and easy to follow practices will affect control of wind exosion. These should be taught and demonstrated eariy in the settlement program and every effort made to see that they are followed.

(1) Maintain a vegetative cover at all times except when preparing the land and seeding another crop. Complete renoval of wheat stubble as practiced In Afghanlstan will be dangerous on sandy soils unless followed inmediately by seeding of a cover crop of some sort. Preferably, the new crop should be seeded in the stubble of the harvested cxop so as to give some protection to seedlings. This means both surmer and winter crops should be grown.

(2) Blow so as to leave the surface rough and cloddy to check the soll from blowing until ready to sead. The clods will slake easily on wetting and the seed bed can be harrowed as seed are broadcast.

(3) Add organic matter to the sol1 through use of green manure crops, stubble and animal marnures. A legume used as a green manure erop at frequent intervals will help assure good crop yields.

(4) Plant tender plants which are easily damaged by wind and sand in single borders between borders of taller growing, more resistant plantso Thus a border of maturing wheat may protect an adjacent spring crop or several rows of sorghum may protect an adjacent border of late sumner or fall planted crops。

(5) Make protection plantings of tall resistant plants in single or dovble rowe to further protect tender plants if needed.

(6) If wind erogion starts, the blowing area should immediately be plowed dry to form clodse or watered and then harroved or plowed while still moist. In no case should blowing be allowed to rach a stage where shifting hummocks are formed as these will fill canals and windbreaks and are difficult to check.

5. Control of Vegetation in the Main Canals and Drains. Growth of vegetation along the banks and in the canal will, if uncontrolled (1) retard the normal velocities and decrease canal capacity to deliver water, (2) cause silt and clay deposition, resulting in decreased capacity and in channels of uneven Now which may damage canal banks, (3) clog turnouts, checkgates and other structures, (4) make bank inspection and maintenence disficult, and (5) reduce the effectiveness of drains. 
a. Control of vegetation falls into two categories accorilng to type. Bank growth, auch as tules, cattalls, bamboo, willows and tamarisk, can be con-trolled by:

(1) Cutting or Mowing: The best time to gemove the entire plants including the root crown and rhizomes would be in the winter months when the canal is dried up for maintenance repairs. Once this has been done, vigilant patrol of the banks should be maintained during the growing season and the young $p$. ts cut off or removed before they have had a chance to develop a strong root system.

(2) Burning: Mobile weed burners such as used on a stateside "railroad right-of-wayt can be devised with a long flexdble flame nozzle to extend down to the water surface. Weeds which have most of their growth above the surface can be kept under effective control by this method.

(3) Soreying with selective weed poisons: Where no livestock are allowed to browse on the poisoned plants, the use of chemical sprays may be practical. Quite a number of selective sprays have been developed. Selection w11I depend on the plants to be controlled and upon the mechanics and cost of use. Data is obtainable from the states on the developments in weed control by chemicals.

b. The control of pond weeds is more difficult. These root and grow within the canal and have most of their vegetation in and below the surface of the water. Three principal methods of control are In use:

(1) Mechenical Removal: Draglines may be used equipped with sultable excavators having teeth to break loose and drag out the weed growth; two tractors may be used to drag a heavy chain along the bottom of the canal and break loose the floating-type weeds. These would be washed down to checks or other structures and be raked out of the canel or may be flushed out through wasteways. A scraper shaped to the canal bottom section can be constructed for the same type of operation and would serve to cut loose the roots as well. Drainage ditches can be cleaned by this method.

(2) Chemicals or Weed Poisons: Aquatic plants are more susceptible to some chemleals such as napthas and "Benechlor", than are land plants. When these chemlcals are enulsified in ditch-water, aquatic plants are killed. The great danger Iles in use of the water by people and Ilvostock. There is also some danger to field crops if the water is diverted immediately for irrigation. Rapid progress is being made in development of selective chemicals so that a safe control may be in the offing. The latest information on chemical control of aquatica should be obtained and be made available.

(3) Berlodic Drying and Burning: When opportunity permits, the canal should be completely emptied and the bed allowed to dry. Repairs and cleanout can be made at the same time. When the weed growth is dry, it can be raked and removed or burned. The burning will help to destroy seeds, spores and rhizomotous roots. The best times for this work on the main canal would be in January when no water is needed. for irrigation and immediately after the last wheat Irrigation (approximately May 15) before the heavy demand for summer crops begins. Only two or three days of hot sunshine would be required to dry out the water plants at this time of year.

There is no one method that is cheap and infallible. Weed control is a congtant expense that must be reckoned with in ditch operation and maintenance. For the Boghre it would appear that, after the initial cleanout, the combined use of hand labor to control ditch bank weeds and periodic drying and burning to control. 
aquatic woeds would prove feasible and economical. The initial cleanout of the worst sections prior to major water demands in the Marja and Shamalan may require use of dragline or other heavy equipment in the upper reaches of the Boghra.

6. Flood Control. Sevêre damage occurred to flelds, bridges, canals and outlet drains along the bottom lands of the Helmand River in May and June, 1957. In Cbapter III, Water Resources, it is pointed out that such floods may occur every three to 5 years. Had it not been for the effect of the Kajakal dam the damages would have been much greater.

The only flood control device of any real value to the Helmand Valley development is the Kajakal dam and reservoir. Unfortunately the full value of this structure for flood control has not been utilized. From data given on inflow in Table 25, Chapter III, it can be seen that 75\% of the total flow of the Helmand comes down in 4 months or 2.7 times the present active storage capacity. If the reservoir was almost empty at the beginning of March and the gate valves held wide open ( 8,500 cusecs) for the next three months, the reservoir would fill and spill 300,000 acre-feet on the average. Since the remainder of the year would jield another 867,000 acre-feet the total of $2,267,000$ would be 4 times the present use demand. It is not necessary that waters be held in the reservoir prior to the annual high flow Even the lowest runoff year on record would 1111 the reservoir to $90 \%$ of capacity in the four months of March to June. Damages to structures along the river can be greatly reduced by taking every advantage of the storage capacity of this large reservoir without in the least affecting the late summer irrigation requirements down stream.

Additional storage and controls would be needed downstream if the Chakansur area is protected from annual flooding. As pointed out in Chart ID 134 Chapter III, about $4,000,000$ acre-feet annualiy can be expected to enter the basins each year. The following chart is extracted from the Chakansur Report to show the accumulative flood volume expectancy from all rivers emptying into the Chakansur Basin and the accumulative effect of various storage and flood control devices up toc ithe riaximum that could be provided by any practical means. A flood of 150 year frequency would exceed the maximum protection indicated。 (Chart ID-175)。

Protection for such river valley Irrigation structures as the Shamalan Canal are needed but w111 be subject to frequent damage and possible destruction unless the reservoir is so operated as to utjlize its major capacity for reducing the high flow peaks which are of sather frequent occurence. 


\section{9}

\section{CHAPTER VI}

\section{WATER REQUIREMENTS AND FERTIIITY MANAGEYENT}

\section{Crops}

It was pointed out in the discussion of climate, Chapter II, that a la variety of crops can be grown in southwest Afghanistan. Growing seasons $r$ from 250 - 300 days. Freezing temperatures seldom last more than a few $h$ temperatures below $20^{\circ} \mathrm{F}$. are relatively infrequent. No 24 whour perior occurred at Kandahar. Common fruit trees willl stand temperatures recent publieation stated that the following species would stand? temperature without in juxy of Pecan: $50 \%$, carob: $15^{\circ} \mathrm{F}$., Japanesi olive: $15^{\circ} \mathrm{F}_{0}$, sour orenge: $28^{\circ} \mathrm{F}_{0}$, date paims $15^{\circ} \mathrm{F}$ 。

Table 16 shows that on a tonnage basis the present anmua products is wheat: $45.20 \%$, corn: $22.25 \%$, vegetables: $19.10 \%,{ }_{0}{ }_{2}$ o products: $8.45 \%$, and all others: $0.20 \%$. Thus grains constiturte $\%_{s}$ ? produets consumed.

Table 18 estimates that of the land in crops the distribution is: orehards: $4.6 \%$, vineyards: $13.1 \%$, wheat: $63.1 \%$, alfalfa: $5 \%$, vegetables: $6.5 \%$, corn: $5.0 \%$, and ell other crops: 209\%. The extremely high percentage in grain crops, part1eular2y wheat, correlates with the high grain diet. Considerable fruit is exported. Animals are ralsed chiefly on desert renge, so the acreage figures do not necessarily correlate with consumption.

A traffic survey conducted October 16, 1952 to October 15, 1953, indicated that exports moving through Kandahar to Chaman consisted of fruits: $76 \%$ (tonnage basis), cotton: 11\%, wool and skins: $12 \%$, anise: $0.48 \%$, others: $0.52 \%$. The total tonnage wes 56,860 and the dollar value at 42.534 :I was estimated at $\$ 7,000,000$, or $\$ 125.00$ per ton.

The Helmand Valley Development Program July, 1953 suggested a shift toward the higher value cash crops, such as fruits and nuts: 16\%; cotton, sugar beets, oll seed crops and other fiber crops: $17 \%$; with 23\% in legumes, hay and pasture. By growing a greater amount of legumes, soil fertility could be improved and yields ita creased. More animal products would be available for sale and mamures could be rew turned to the soll. Less land would be required for wheat as the ylelds would be boosted.

In setting up land settlement programs among the farner applicants HVA has suggested the following: vineyard 2.

Class I - 15 jiribs ( 7.5 acres): alfalfa $2, \operatorname{cosn} 6$, cotton 4, garden and house $2_{2}$

Class II -20 jiribs (10 acres): alfalfa $2-5, \operatorname{cosn} 6$ or cotton 4, wheat $5-10$, garden and house 1, vineyard $1=2$. 
Class III -25 jiribs ( 12.5 acres) : 5 alfalfa, 4 cotton, 406 corn, 8-10 whee garden and house 1 , vineyard $1-2$. house.

Class IV - 30 jiribs (15 acres): 5 alfalfa, 20 wheat, 3 corn, 2 garden anc

This sort of program would still overstress grain pioduction. It would allow fruits and vegetables for an average family but would provide three tf the grain necessary for a well-balanced diet. More land should be donated soil-builiding legume crops for iraproving crop ylelds. Less land need be $\dot{i}$ to low value grain products and more to products of fering higher econom" such as fresh and dried fruits, nuts, fiber and oil seed crops and sugar

The ratio of acreages allowed for farms of different land classes reflect the potential productivity of these lands but is an arbitrar. by Afghan authorities. When the lands have been fully developed and (see Stage 3 of Physical Stages of Soil Development, Chapter VIII) th duction values for Classes I - IV, using the above acreages in crops, good farm management in the ratio: $-I=1.00$, II $=0.955$, III $=0.812 \mathrm{~N}$ For equal gross production values then, the farm sizes should be nearer $I$ II $=21$ jistbs, III $=31$ jixibs and IV $=49$ jIribs. It has been pointed out in previous studies that these. low acreages may barely sustain a family in the early stages of developtnent or even fail to do so. Even after full development the in centive for doing an efficient job of farming may be stifled by overerowding on small acreages. Public revenue accrued through taxation of marketable farm surplusses is needed for retirement of public indebtedness for the overall development. Much good can come through a study of ways and means to raise more per family than the family can consume and to find suitable markets.

Several crops which may be introduced or expanded in S.W. Afghanistan are the following types:

A. Fiber Crops - Cotton, hemp, flax, ramie, and silk. Silk culture while an old and established enterprise in Asia, has received new impetus in this country through efforts of the $U_{0} N_{0}-F_{0} A .0$. experiments at Baghlan. Some notes on this crop as furnished by the $F \cdot A_{0} .0$. expert follows

\section{Sericulture - A new moner crop for Afghanistan}

1. Graft onto native mulberry stock a non-fruiting Japanese varlety of mulberry which produces leaves relished by silkworms. (This has been done on some $40,000-$ 60,000 trees in Baghlan. Nearly two million mulberry seedlings growing to be grasted.)

2. Introduce high silk-producing strains of silkworm. (Silkworms from eggs brought in are now producing silk at Baghlan.)

3. Prepare land by growing a green manure crop of legumes, turning it under and thoroughily diseing the soil ahead of planting trees.

4. Plant trees 1 meter apart in row 3 meters apart so that inter-tilining can be done. This spacing can be varied to grow 1250-2000trees per acre.

5. Grow winter vetch or clovers between tree rows and turn under as green manure, a regular practice in sericuiture. 


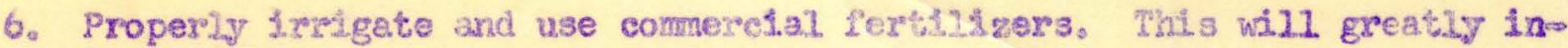
cresse leaf glelds.

7. Results of some tests at Baghland showed that a yleld of 14,400 1bs. le produced, $720 \mathrm{kllos}$ of cocoons (100 seers) valued at $180 \mathrm{Afs} / \mathrm{seer}$ or $18,000 \mathrm{~A}$ Acre or $\$ 4.23 .20$ at 42.543 AIs. $\$ 1.00$.

b. Fruit Crops - dates, citrus, olives, flgs, The production of suitabi and packed frults for export could be an increased source of income even thr several milition dollars' worth of fruits are exported amually now. Consids care should be taken in selecting base stock for citrus and olive piantinf more winterhardy types will be needed. Native olives are growing in the provinces. Some of these could well serve as a root stock for fo "ting types. The country needs other sources of edible olls and fats tipg
(roghan-l-gosphand).

c. 011 see/crops - olive (above), cotton (seed for oll and prot bean (011, edible food, animal sood, numerous comnercial products) 011, soli buliding cxop), castor beans (medical, Iubricating and 1 sesame, and others.

\section{d. Nut Crops - Pecan, walnui, plstachio, almond.}

0. Hay and Pasture Crops - Many kinds of legumes and grasses can be grown.These need to be increased considerably, not for livestock production so mach as to provide organic matter, build soll structure and add nitrogen to the soil. The practice of removing ail vegetation from the land is comon here. The soils have become so low in nitrogen, organic natter and readily available phosphorous that crop ylelds have reached a low level. Turning under a green legume crop has quadrupled grain yields on some solis in the Nad-1-AII area. Because commercial fertilizers are not available hexe, it is even more urgent that legumes be grown for soil building. The lack of fuel forces the burning of animal dung, thus destroying one of the most valuable soll builders available, Many soils, especially of Class IV lands, are better suited to livestock production rather than to eash grains. Legumes and grasses which can produce fair returns on wet, saline solls are needed in many places.

In general every cash crop should follow a green manure crop unless commercial. fertllizers and animal manures are used. The mild winters make it possible to grow winter legunes such as vetches or winter peas, following a summer crop. The growth can be pastured some during winter and early spring and turned under for green manure a few weeks before the next sumer crop is planted. Ionger-growing deep-rooted legunes such as alfalfa, along with deep-rooted grasses, should be grown in the sotation as often as practical.

\section{Water Requirements of Crops.}

2. Plant Growth Habits Affecting Water Use - Plants Partheir growth habits and in the use of water for growth. Irrigation is concerned with supplying water to each erop in a manner caleulated to control its growth and production habits for greatest economic returns. For instance, if forage is desired, water application may be liberal and frequent; if seed production is desired, a stress period may be introduced. Some plants if watered too heavily at fruiting time may produce 
extra vegetative growth rather than set and mature fruit. Grapes and pomegranat watered too liberally during ripening period may burst and spoil.

\section{(1) Root distribution and moisture use.}

Many plants draw most of their water from the 6" $-18^{n}$ layer of soil. $0^{4}$ as deepmrooted trees may feed to several feet. Walnuts have been reported the soll moisture to near the wilting coefficient up to 12 feet before shr in juxy.

Table 52 shows graphically the rooting habits of various types of this graph crops may be selected for adaptation to different effectiv Nost crops do best on deep, well-drained soils, but many are capable. to a wide range of soils depths and textures. Grapes, as lilustrater were found at Indio, California to draw $66 \%$ of their moisture from feet, $29 \%$ from the next three feet, and $5 \%$ from $6=9$ feet or lower. with a water table at 1 meter have been observed in several Afghar Mesquite and athol roots have been known to penetrate $30-40$ feet i Alfaifa is a deepermoted crop feeding $6-8$ feet or deeper. Where $h$ or hardpan exist, it has been observed to produce fair ylelds wit" root system.

In Table 52 the normal rooting habit in a deep, we) The irrigation water requirements for each crop are cal the rooting habit is more restrictive than soil depth.

\section{(2)}

\section{Planting and cultural methods may affect wat}

The consurptive use requirements of several types gation requirements at selected levels of irrigation ef. the study of Arghandab-Tarnak water allocations, July, ? must be lweps in mind in evaluating water requirements. Octobar through Jaruary so that a portion of the land a portion will be planted after winter rains and will As ilttle as $8^{\prime \prime}$ of Irrigation water has been used in ranges from $1_{4}^{n-18 n}$ 。

Cotton, orchard and vineyard lands may be giver oariy spring irrigation to completely 1111 the root rapid growth begins in May. The deciduous fruits paars, peaches, pomegranates, ligs, plums and nectai. are spaced too closely and are never pruned. Exces: expansion of orchards should bo along lines of good $c$ Including economic use of water.

VIneyards present a different situation. The $v$ trenches 1-11 meters deep which are 8-12 feet apart. meters apart in the rows. The excavated soll is th strip to make a large xidge and the vines are trelis using it as support. Irrigation is done by watering 2. Inquiry among many farmers Indicated $8-12$ waterings of । as a cormon practice. $A$ bout $18^{n_{-}}-24^{\text {n }}$ total water wes ap. 
In setting up water requirements it is assumed that surface plantings may eventually be used on part of the land and a normal consumptive use for this system was included. Research studies show that deciduous fruits and vineyards can be stressed heavily following harvest of fruit without serious damage to the tree or vine. This principle is used to conserve water in late surmer and fall when water supplies are Low.

\section{(3) The effect of reducing water supplies on yields.}

It is well known that for most crops the increnent of yield obtained for an added increment of water above that necessary for bare survival is greatest for the flrst increments added. There is a variable decrease in increment of yleld per added increment of water as maximum yields are approached and, for many crops a decrease in yields if the optimum is exceeded. This latter often results from a combination of causes such as waterlogging the soil, diseases and insects, and vegetative regrowth. Certain legume and hay crops such as alfalfa show relatively the same Increase in yields up to sevaral feet of water, while wheat shows rapidily decreasing ratio of yield for water applied from $1 \frac{3}{2}$ to 2 feet of water and rapid decline in ylelds when over 2 feet are applied. Drawing LD 140 11luctrates these relationships for several common crops including heavy water ugers such as cotton, alfalfa and fruits. In the case of Acala cotton $80 \%$ of full water application gave $95 \%$ of full yield, $66 \%-89 \%$ and $50 \%-74 \%$, respectively. Reductions in yields caused by a $20 \%$ reduction in optimum water supply are shown in chart as: Cotton $\approx 5 \%$, Wheat $=5 \%$, M1lo $=4 \%$, Fruit $=12.5 \%$, and Alfalfa $=15 \%$, respectively. This presumes timely and efficient use of the water received. Over the period of record less than $30 \%$ of the years would appear to have low supply from the Arghandab inflow. Helmand flow is more than ample for all lands now suitable for use. 


\section{b. Crogoing Practices for Erflcient Water Ü3.}

Axlzona, California and New Mexico 1 rrigation research on the basic crops have established sound working princlples by which ixrigation schedules for each crop can be maintained. Brlefly, irrigation should be designed, where water supplies are ample, to maintain the plant at seasonel growth rates consistent with maximum yields whether it be of fruit, grain or forage. This should be done with a minimum of wastage through percolation and runofr. Where water supplies may be lacking, applications of stress at the least critical times is necessary so that reduced molsture supplies will result in the least reduction in crop ylelds. On normal solls when field crops have reduced the molsture to near wilting percentages in the upper $1 / 4$ of the root zone there are increasing anounts of unused water in the successively deeper portions of the root zone. In solls with variable textures and depths, layers other than the top $1 / 4$ of the goot zone may be deploted first. Maximum growth results from refining the plant root zone to near fleld eapacity each tine before the liniting layer reaches the wilting point for the erop being grown. In this manner no portion of the roots feeding water and nutrients to the plant are danaged by drying out. In actual practice with variable water supplies it is not always possible to attain such ideal conditions.

Following are some of the practices found useful for some comnon crops.

\section{(1) Cottons - Californis Method.}

(a) Pre-irrigate in late March or early April (as soon as water supply is known) to depth of 5 feet, if in deep soils, or to known effective soil depth if less than a 5 - foot root zone.

(b) Plant without further irrigation on sldes of lister ridges bes tween April 10th and May 1.

(a) Stress $6-8$ weeks or until squares start to form unless, on medium depth or saline solls, anotzer lrrigation is necessary to prevent permanent wilting :

(d) Irrigato during fruiting period so squares form along lateral branches about $4 "$ apart and no blossoms appear in top branches until late - this may require irrigation every $3-6$ weeks during July and August. In crit.jes.lly hot periods, light ixrigations every 7 days may be needed for cooling offect.

(e) Reduce 1migations after full boll formation and discontime after about September 15.

(2) Azizona Method.

Steps (a) and (b) are the same.

(c) Keap ground fairly moist (near 50\% of watorholding capacity to July 31, or unt11 squares start to forin.

(d) Reduce watering during frviting but not enough to throw squares.

(e) Irrigate as in step (e) above.

(3) Variations for different water yegrs (pre-irrigate in 211 caseg). 
(a) Planting April 15ullay 5.

(b) lst Irrigation: Wet year June 25-july 5; normal year July $1=25$, dxy yeax July $15-25$.

(c) Second Irrigation: 3 to 6 weeks later.

(d) Later Irriggtions: Wet years 2/2-weeks apart and 2/3-weeks apart; normal years $2 / 2$ nfeels apart and no more unless serious w1Iting occurs; dry years 1 July irrigation and 1 Augugt may suffice or irrigate during fruiting poriod only.

\section{(4) Grspes}

filil root zone。

(a) Pre-irrigate during dormant season or very early growing season to

(b) Stress eariy growth unt11 upper root zone is neariy dry.

(c) Irrigate from then ab early blossom time until fruit is woll filled but not spo. Keep root zone well akove wilting polnt.

(d) Do not irrigate or irrigate only lightly during ripening and until fruit is harvested.

(e) After harvest, early grapes may need one or more irrigations to prevent Loss of all leaves before frost. Grapes may be stressed heavily after harvest without harm to the planto

Present vineyard irrigation practices vary widely depending on water supply. Some lrxigate every month of the year as follows: la-6" irrigation each cool month, then 2-6n 1rrigations each warm month, and 3-6n 1mrigations each hot montho Some irrigate only once in the winter months and twice in the fall months. Since the custom of planting grapes in deep trenches is variable in depth and spacing, it is difficult to reconcile farmers' statements with actual vineyard requirements.

\section{(5) Orchards}

(a) Certain trees such as olives, figs and almonds withstand dry soll conditions much better than others such as peaches and apricots. While a general irrigation schedule has been set up for deciduous frusts, it is recognized that water application rates and time of application will vary by species.

(b) Research by Viehmeher and Hendrickson indicate that many trees can obtsin water equally woll at any moisture content between fileld capacity and fleld wilting percentage and that some trees can exist at or nesr the wilting percentage for several weeks without serious injury, particulariy after fruit harvest and in dornant periods. Keeping the moisture content at a high level by frequent irrigaw tion produced no more or better fruft then psacticos which allow molsture depletion noarly to the field wilting percentage before ro-irrigation. If

(c) Deciduous trees may drav water unifornily from the soil to 5 or 6 feet. Welnuts have baen known to extract moisture to 12 feet in a uniform loan soll. Peach treas may show slgns of wilt when the molsture in the top 2 or 3 feet is exhausted. The behaviour of erch species in a given 3011 must be known in order to set up a sound irrigation schedule.

If F. J. Viehmeher and A. H. Fiendrickson, Proceedings Am. Hort. Soc. Vol. 55, 1950 
(d) Whlle deciduous trees may do better if they have readily availabie molsture at all seasons, the fall irrigation may be redveed or onfted with less danger of Injury should lack of water supplies make this necessary. Citrus fruits need enough water throughout the year to keep the soll root zone above the wilting point.

(e) Winter or early spring imiggtion to full effective soil depth is desirable but care should be exercised to prevent waterlogging soils over permanent watertables or slowly permeable substrata.

In the Arghandab-Tarnak Area because of conditions imposed by the water supply the following practicas are necessary - (a) Irrigate so that in January to May inclusive the growing requirements are net and the soll within the root zone Is brought to full capacity at the end of May; (b) June, JuIy and August irrigations plus soil storege should meet consumptive use requirementis: (c) in September trees may be allowed to nearly deplete soll stored moisture, since most of the fruits except pomegranates will have been harvested; and, (d) October-Decembsr ixrigations may be kept to the minimum necessary, to prevent coraplete loss of leaves bom fore frost.

\section{(6) Wheat}

Wheat is planted from October through Fobruary. Both fall and spring wheats are grown. Irrigations are made usually as follows: (a) pre-1rxigation, (b) onea in fall months, (c) at 5-leaf stage, (d) at early boot stage, and (o) at milk stago. Fall whest planted by mid-October on fallowed land appears to give the highest yields. On the other band, lack of water for Iall planting has led to the practice of planting spring wheat using winter and spring reins, spring runoff and limited diversion from the river to complete the erop. In the plans for the Arghandab-Tarnak Area, water for $1 / 3$ of the area is provided for fall planted wheat. Provisions are made for full 1rrigation through to the 15th-20th of May when imigation should be discontinued to allow ripening of the graln. Variations in percent of fall and spring wheat and in watar applled may be necessary in dry Jears.

\section{(7) Winter Cover Crops and Legunes}

Provision is made over and above orchard and vineyerd irrigation for grow Ing winter cover crops and also for winter legunes seeded on cotton lando The winter cover crop might be delayed unt12. Novernbar in dry years or omitted altom gether.

\section{(8) other Surmer Crops}

Truck crops may be planted in spreing, sumer or fall. It is not expected that the acreage will bo high as marisets and shipping facilities are not available. The average of severel species in each group was used to compute ixrigam tion needs. Summer legumes would bo pianted os about $1 / 3$ of the wheat land each year there was axple wator but would be omitted in years of short water supply.

\section{c. Methods of Computing Water Use by Plants.}

(1) The Blaney-Criddle formula comparison was made in Chaptor I Section 2, of the Blaney-Criddle formula and the Neyer formula for determiniag irrigation water requirements. The Meyer formula uses wind velocity and free water evaporation data along with temperature and muidity. 
Because the Blaney formula has boen used widely and Is generally accepted it is used herv. Omly in the lower Darwoshan, Carmsel and Chakansur Areas would consideration of wind velocities apparentiy make substantial difference. In the supplemental reports for these areas the wind velocity factor will be shown.

The consunptive use formula, as used by Blaney and Cxiddle, expressed mathomatically, is $U=K F=$ Summation of monthly KF where...

0 - Consumptive water use of a crop (or evapo-transpiration) in inches for any persod.

$F=$ Sum of the nonthly consumptive use factors for the period (sum of the products of the mean monthly temperature and monthly percent of daytime hours of the year).

$\mathrm{K}=$ Empirical consumptive water use coofficient (for the irrigation season or a given growing period) based on research studies in similar climates.

$t=$ Mean monthly temperature in degrees Fahrenhelt.

$p=$ Monthly percent of daytime hours of the year.

$f=\frac{t p}{100} \mathrm{monthly}$ consumptive use factor.

k = Monthly consumptive use coefficient.

$\mathrm{u}=\mathrm{kf}=$ Monthly consumptive use in lnches; and

$R$ - Sum of effective monthily preclpitation for growing period or irrigation season.

$I=0, R=$ Irrigation requirement for year or growing period.

$\mathrm{E}=$ Field-Irrigation efficiency.

r Monthly precipltation in inches.

$I 0=\frac{\pi-R}{E}=$ Irrigation requirement at head of fleld for year or Ien $=\frac{u}{E}$ for

month. ooohas been used in devaloping 1rrigation requirements.

The values for $K$ used in this study are those suggested by Blaney and Griddle with modifications based on data from other comparable areas.

Monthly water consumption by crops was determined and an lmolgation requirem ment for each crop was developed in Table 55. Selection of crops to be used in a rotation, based on their peak demand periods for water may be made from the table. Irrigation is commonly by the check border or contour basin method. With properly controlled application, deep percolation and surface runoff losses can be minimized. Farm efficieney which is practical to obtain $w a s$ estimated to average 40 s $60 \%$ for vine and frult crops. All others were valued al/50\% irrigation efficiency. According to Blaney-Criddle, and Israelson.e these assumed Irrigation efficiencles are within practical linits. These levels should be easily attainable when farmers are given some training in the importance of careftul water mansgenent. 
(2) Climatic Aress. The watershed area has been divided Into three najor clinatic areas for water use requirements studien. The Tarnak-Arghandab Area has been studied and reported in a separate report. I/ The central Helmand Valley and Lower Helmand-Chakansux Areas are hotter, have longer growh, seasonal and somewhat different latitudes.

Tables 53, and 54, show the computed "I factor for the cantral and lowex Helmand Areas as compared with Kandahar. The correction factors shown are used to adjust crop requirements from Chart 55 to the area concerned.

\section{d. Water Requirements of Crops Grown in S. W. Afghanistan.}

The series of large charts, Table 55, (4 pages) brings together the combined effects of climate, growing seasons and water use babits of the crops which may be grown. For each crop the nornal land preparation and seeding period, actively growing perlod and perlod of harvest, dormency or fallow are given. The consurpm tive use In acre-inches per month of active growth are indicated. For some crops the variations in percentage of total water used is shown by months, The range of seasonal consumptive use and conmon or average use is given at the right of each crop together with the seasonal variation and averages of the consumptive use coefficients.

The chart allows the choice of rotations for a given soll to be so selected as to allow one or several crops a jear. The consumptive use of each crop can be quickly computed. By application of known or assumed water delivery and farm 1rrigation efficiencies the amount of water necessary to divert and deliver/the farm head. butes each month can be determined. As explained in the footnotes to the chart there are many local variations that must be worked out by the farmers themselves for full knowledge of the absolute requirements of all crops would require years of research. These data based on all avallable information will servo as a gen eral guide, however.

Conversion factors for the central and lower Helmand areas are given on page 4 of the chart. These are based on differences in average monthly temperatures and monthly percentages of total sunshine hours as given in Tables 53 and 54 . Consumptive use calculated by these conversion factors compare Lower Helmand with such areas as Mesa and Tueson, Alizona. When the wind velocity factor from Table 8, Chapter I is applied, exaggerated use coeffleients 160-180\% higher rasult. Until fleld experfence fruxishes some evidence of the effect of the high sumer winds of the Chakansur on Wator use by orops, the Blaney-Criddle formula will serve as a reasonable guide to consumptive vir.

Water use requirements by crops and by projects are included in the supplementary reports. A sumnary of these for the Arghandab-farnak projects has been reported on in the water allocations study. The calculated crop use gfarm delivery and diversion requirements for Helmand projects under command of Helmand River water are summarized in Table 56 . 


\section{COMPUTATION OF CONSUMPTIVE USE FACTORS FOR CENTRAL HIBLMAND VALIET APRA}

\begin{tabular}{|c|c|c|c|c|c|c|c|c|c|}
\hline \multirow[b]{2}{*}{ Yonth } & \multicolumn{4}{|c|}{ Mean Annual Temperatuse - $\Gamma^{\circ}$} & \multirow{2}{*}{$\begin{array}{l}\text { \$ } \\
\text { Totel } \\
\text { Sunshine } \\
\text { Hours }\end{array}$} & \multirow{2}{*}{$\begin{array}{l}\text { Isactor } \\
\text { stp/100 }\end{array}$} & \multirow{2}{*}{$\begin{array}{l}\text { Corro } 1 \\
\text { factor } \\
u^{\prime}=\frac{u \rho^{0}}{2}\end{array}$} & \multirow{2}{*}{ 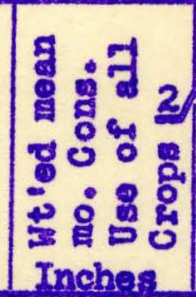 } & \multirow{2}{*}{ 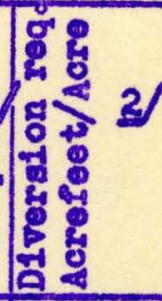 } \\
\hline & & $\begin{array}{l}\text { Chah-1- } \\
\text { Anj1 }\end{array}$ & $\begin{array}{l}\text { Lash- } \\
\mathrm{kar}- \\
\mathrm{ga}\end{array}$ & $\begin{array}{l}\text { Weighted } \\
\text { Mean }\end{array}$ & & & & & \\
\hline Jan. & 46.7 & 45.8 & 16.5 & 16.24 & 7.220 & 3.34 & 1.0536 & 1.01 & 0.19 \\
\hline Febo & 53.3 & 52.1 & 52.5 & 52.14 & 6.990 & 3.64 & 1.0769 & 7.08 & 0.20 \\
\hline Mare & 62.5 & 60.2 & 67.3 & & 8.370 & 5.14 & 0732 & 1.47 & 0.28 \\
\hline Aore. & 73.0 & 75.0 & 56.9 & 67.73 & 8.740 & 5.92 & 2103 & 2.50 & 0.47 \\
\hline Mas & 83.8 & 83.2 & 79.5 & 82.20 & 9.600 & 7.89 & 0867 & 4.49 & 0.85 \\
\hline June & 87.7 & 89.2 & 85.5 & 87.72 & 9.500 & 8.39 & 1.0825 & 4.02 & 0.76 \\
\hline Ju18 & 93.0 & 92.2 & 89.0 & 91.26 & 9.745 & 8.89 & 1.0775 & 4.97 & 0.94 \\
\hline Auge & 87.2 & 85.4 & 85.6 & 85.77 & 9.270 & 7.95 & 1.0525 & 4.11 & 0.78 \\
\hline Septse & 80.6 & 77.9 & 77.4 & 78.18 & 8.340 & 6.52 & 1.0724 & 2.21 & 0.12 \\
\hline oot. & 66.3 & 66,4 & 62.9 & 65.22 & 7.950 & 5.18 & 1.0237 & 0.93 & 0.18 \\
\hline Nor. & 58.5 & 55.2 & 56.6 & 56.22 & 7.130 & 4000 & 1.0498 & 0.48 & 0.09 \\
\hline Deco & 49.3 & 48.8 & 47.9 & 48.58 & 7.080 & 3.44 & 1.0990 & 0.87 & 0.16 \\
\hline rotals & 847.9 & 832.8 & 800.7 & 822,65 & 200.00 & 70.30 & 12.7570 & 28.14 & 5.33 \\
\hline Means & 170.1 & $69 \mathrm{~d}$ & 66.6 & 68,55 & - & $=$ & 1,0631 & D- & $=$ \\
\hline
\end{tabular}

If Relation of Marja-Chah-1-Anj1rs-Lashkarga area to Kandahar 1s expressed by oquation $u^{\prime}=\frac{\text { uf }}{\mathrm{f}}$ where $u^{\prime} f^{\prime}$ represents the area and uf the Kandahar data。

2f This camparison is based on the weighted mean value of consumptive use of all crops adjusted to the total area of 185,000 acres of the Arghandab-Tarnak area。 The figure is valid only if the same cropping pattern and irrigation efficlencies are used. (See Arghandeb-Tarnak Area Water Allocation Study - 7/56)。 
TABUE 54

COMPUTARION OF CONSUMPTIVE USE FACTORS FOR LOWIGR GMTMAND AREAS

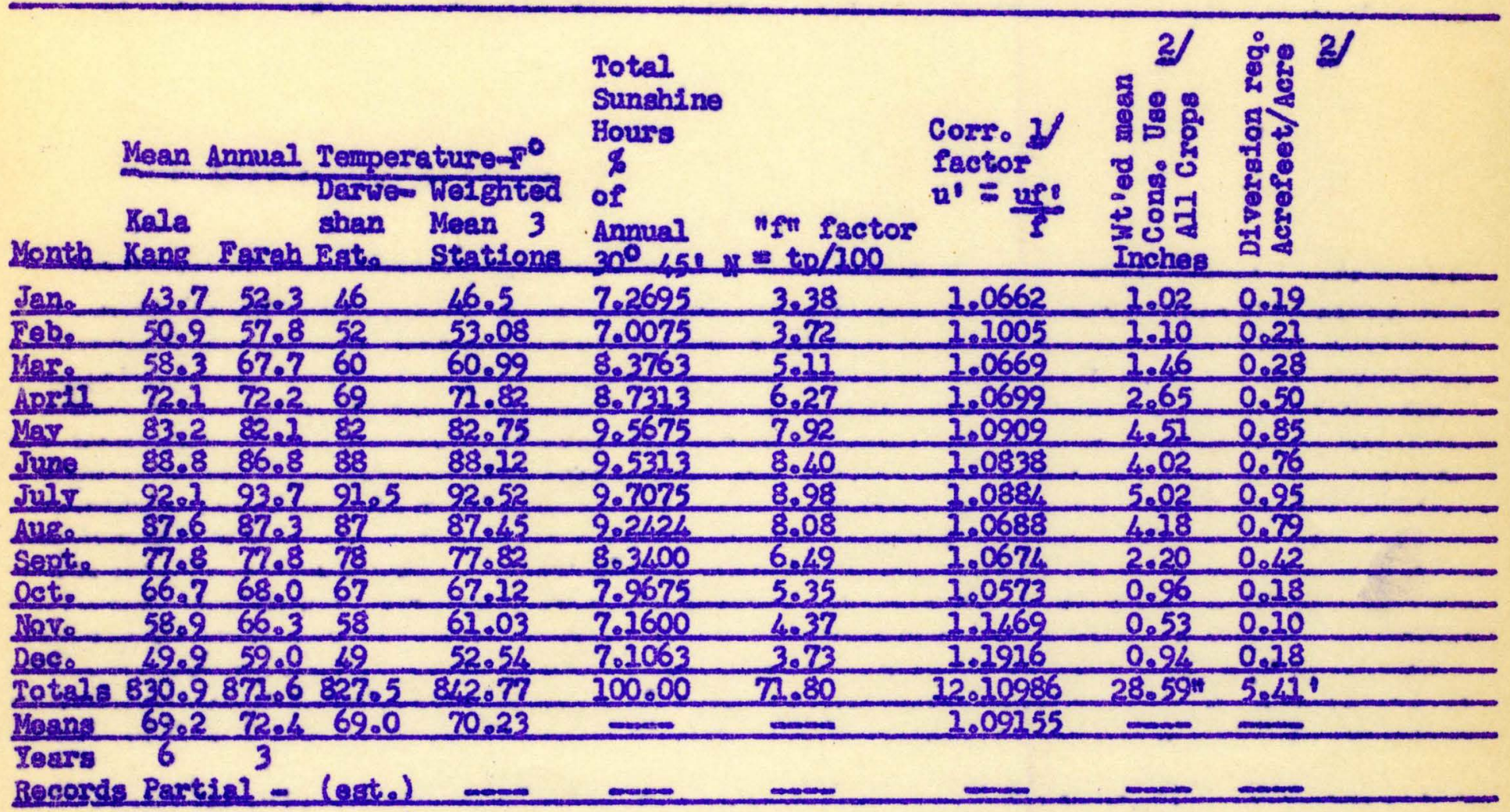

If Relation of Lower Helmand Area to Kandahar Area is expressed by equation ul $=\frac{\text { uf }}{\mathrm{I}}$ where
u'f' represents the area and uf the Kendahar data. 2/ This comparison is based on the welghted moan velue of consunptive use of all crops adJusted to the total area of 185,000 acres of the Arghandab-Tarnak Area. The Ilgure 1s valid only if the aane cropping pattern and irrigation officiencies are used. (See ArghandabTarnalk Area Water Allocation Study $7 / 56$ )。 


\section{Fertiliners}

A brilef report on the need for and cost of fertilizers for S. W. Afghanistan was made in $1955 \mathrm{I}$, and a study of possible fertilizer production was in cluded in the Industrial Survey Report 2/. Geologic and mineral surveys, all of a general nature, have thus far failed to reveal fertilizer raw materials in Afghanistan. Some small guano deposits of relatively little significance were located,

Many Afghanistan solls heve been used over several centuries. If present agriculture reflects past usage little or nothing has been done to restore or improve soil fertility other than by fallow methods which so far as observed con sist of periods of abendoment of $1-5$ years. This is one reason other than water shortage why one observes only $1 / 2-1 / 5$ of the laad annually cropped. Contlmuous cropping to wheat at Nad-i-Ali resulted In yields from the first year to foux years out of desert of $28,12,8$ and $(5-3)$ bushels, respectively. All atrau and whoat is completely removed and the land left berren after harvagt. It can be wald that the fertility levels of most of the land over the Helmand/at a minimum leval. Neas villages and large towns the use of animal mamxes and night soll has maintained a few acres at higher levels.

Small amounts of nitrogen are added to the soil by rainfall and Irrigation water. Non-symbiotic bacteria (1ive without host plazt or legumes) may take from the air several pounds of nitrogen. A few leguninous plants such as camel thorn grow in fallowed fields and help Iix nitrogen. Thus by lesving the land idle one or two years sufflclent nitrogen may be recovered to produce another meagre cropo

Much can be done without fertillzers to bulld up soil productivity and tilth. The following 1llustrates the nitrogen regime in an irrigated soil:

Table 57 Additions to Nitrogen

Removal of Nitrogen

Irrigation and rainfall

1 ton of straw turned under

Wasted seeds

Legume crop turned under

Non-symbiotic fixation

Nitrogen additions

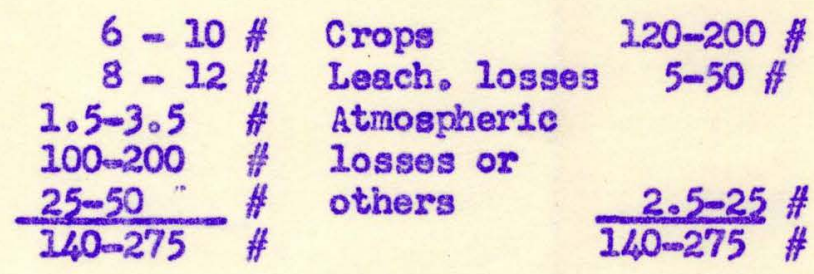

Thus without fertilizers but with proper attention to grouth of legume crops and turning these under at the right stage will provide nitrogen to produce sevm era? times the yield now being produced on the average Afghan Iarm.

Table 58, gives the anounts of plant food nomally removed by different crops at the levels of production expected at different stages or levels of lrrigation development and Ixrigation farming. It can be seen that high production will reo quire ut1liaing every means possible to bulld and maintain a bigh fertility level. The cheapest most available sources mist be used at firsto of these, as shown above, leguminous crops are good sources of nitrogen. The value of the crop ficr green manure is not greatly reduced if grased moderately and the animal dropplngs allowed to return to the soil. Table 59, shows the fertilizar value of excrement and bedo ding from different animalsa The fertilizer value per year at present commercial

$1 /$ Fertilizer problems in Southern Afghanistan - 3/18/55, MRA Land Dev. Division. $2 /$ Helmand Valley Industrial Survey, Phase I, MKA., November, 1955 


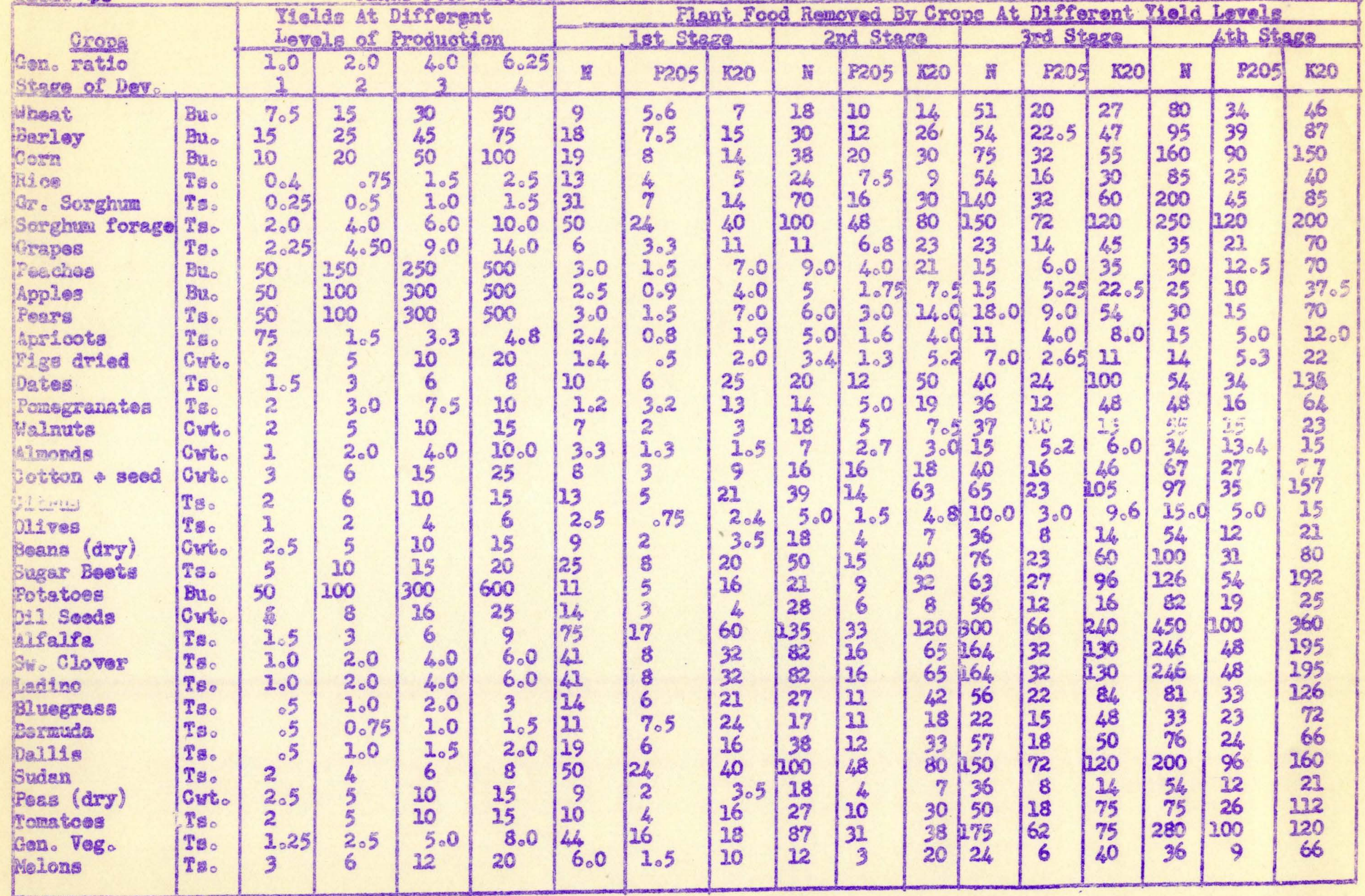


BLAN MWRIENTS IN ORE TON OF DTFFLRENT MANURES (Ircludes vol1d, Iiquid and bedding)

Table 59

August 22,1956

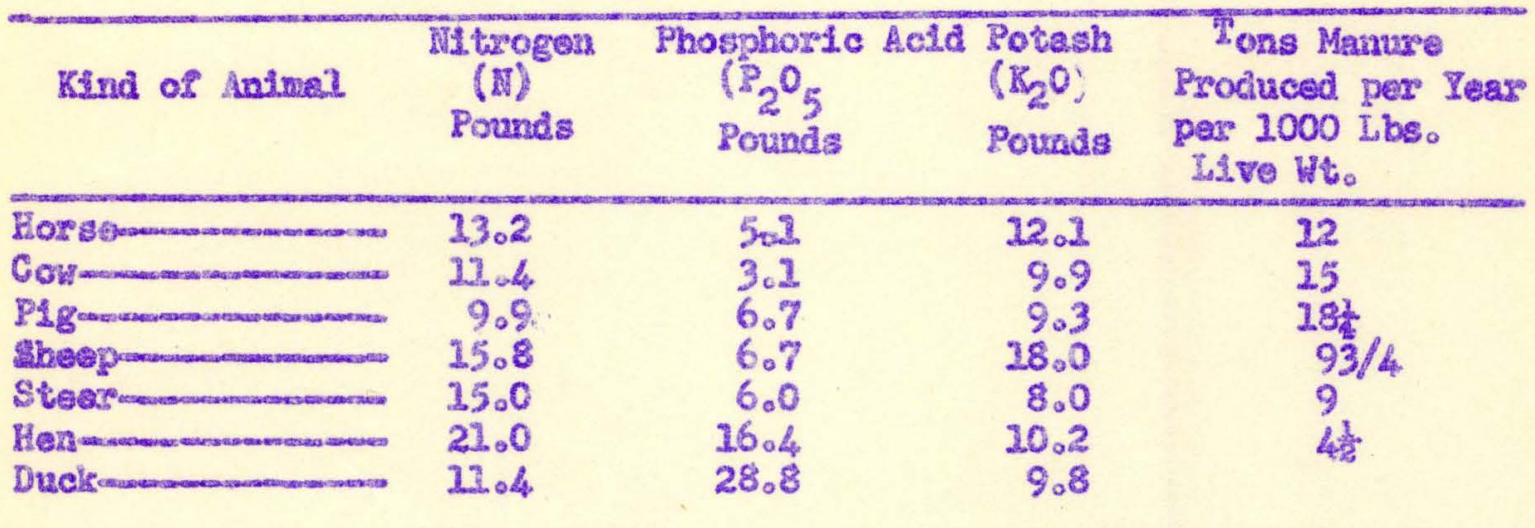

Source: Cornell Uhivarsity

" Fron "Oux Land and Its Caxe", Prepared and publishod by the Amard can

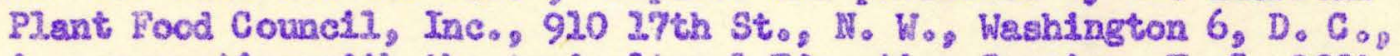
In cooperation with the Agxicultural Education Service, DoS. Office of Bducation, Federal Security Agency, Washington, D. C.

NOTE: To preserve manures add $25-30$ \# of $40 \%$ superphosphate to poultry or cattle manures and 40 t/ to horse, sheep and goat manurs. Use about 9 f of gtraw par cow for bedcling per day and 1 \# per day for sheep In seed lots. All manure composts should be layored with bedding and fert111zer and protected from rains and from extreme heato 


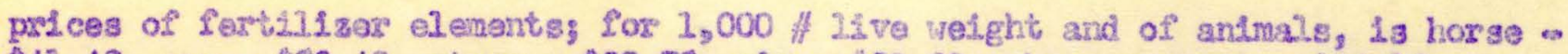
$\$ 42.4 \mathrm{O}_{2} \mathrm{cow}-\$ 83.4 \mathrm{O}_{2}$ steer $-\$ 30.78$, pieg - \$52.92, sheep or goat - \$44.18, chicken - \$24.75 and duck - \$26.80. The burrating of dung for Iuel is a wasteful practice. No fertilizer is of greater value in sol1 improvement than animal. manures. Commercial fertilizers are more effectivo whon applied with liberal quantities of mamures. Other organle fertilizers may also be used such as straw, cotton buxrs, and littchen refuse. Table 60 . 11sts a number of othex organic ferti.1. izers and thelr average analysis.

The cost of fertilizers is the Exeatest detriment to their use in Afghrndstan. The long boat, rail and truck haul. nakes shipping costs aqual to or groat-

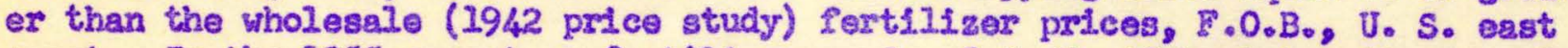
coast. In the 1955 report on fertilizer needs of S. W. Afghanistan it was pointed out that the beglnning of fert1lizer usage in any measurable degree might be 15-20 years after project development. U1timately 50 w0\% of the land could make profitable use of fertillzars. Table 6I, taken from the former report shows the gross fertilizer needs of $S$. W. Afghtingtan based on the erop acreages shown in the 1953 report. There will be some shifting in crops from that shown as well as In the total acreage of crop land. The general estimate is $\mathrm{fal}_{\mathrm{s}}$, however, and may be adjusted percentagewise to the land aree finally determined irrigable.

In the above mentioned report it was shown that the annuel shipment cost alone of fertilizers purchased abroad could amount to $\$ 760,000-\$ 3,500,000$ on the amount shown in Table 61 , as needed. Savings in frelghtage costs could easily amortias investments of 15-50 million dollars in developing local fertilizer manufacturing.

The potential need for fertilizers in the Helmand Valley alone justifles intensive search for suitable minergis within the country and a thorough atudy of their development costs, if found. The prior emphssis on seerches for sources of power and fuel is necessary since these will be needed In the processing of fertilizers. Considerable electric power can be made available at Kajakal and Arghande.b.

Freight costs alone for shipment over the gxeat distances fron external fertillzer sources may amount to more than the anortization costs of adequate fertilizer plants to serve the country's neads.

Potential production without use of fertilizers has been 11 barally ostimated. Such production can be obtained only if proper drainage and Irrigation prectices are coupled with the liberal use of green manuses and legune crops, and malntenance of auitable controls over salinity, alkalinity and exosion. On the older solls perticularly, and on all lands as irrigation proceeds, yields will tend to decrease without fertilizers. Maintenance of ylelds adequste to justify tha majos agricultural development now golng on in the Helmand Basin cannot be obtalned unless sound soil fortility practices are invoked.

The above study would indicate that search for phosphate-bearing minerals is of first importance. Sul phur and coal deposits now known may be adequate for prom cessing but deposits noarer the Helmand development area may be found. Potash deposits are of much less importance but nevartheless search for these should be included. Iocal nitrate beds would be valuable if found, however, firation of atmospheric nitrogen will more than likaly be the bast source of this plant food element. 
AVERAGE ANALTSIS OF ORGANTC MATERTALS

Table 60

\begin{tabular}{|c|c|c|c|c|c|}
\hline $\begin{array}{l}\text { Bujiky Osganie } \\
\text { Naterials }\end{array}$ & $\begin{array}{l}\text { Percent } \\
\text { Mistrogen } \\
\text { in }\end{array}$ & $\begin{array}{l}\text { Percont } \\
\text { Phos- } \\
\text { phorous } \\
{ }_{2} \mathrm{O}_{5}\end{array}$ & 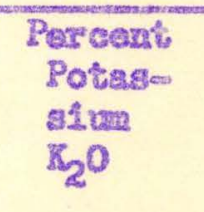 & $\begin{array}{l}\text { Percent } \\
\text { Organie } \\
\text { Matter }\end{array}$ & $\begin{array}{l}\text { Cubie } \\
\text { Foet } \\
\text { por } \\
\text { Tou }\end{array}$ \\
\hline 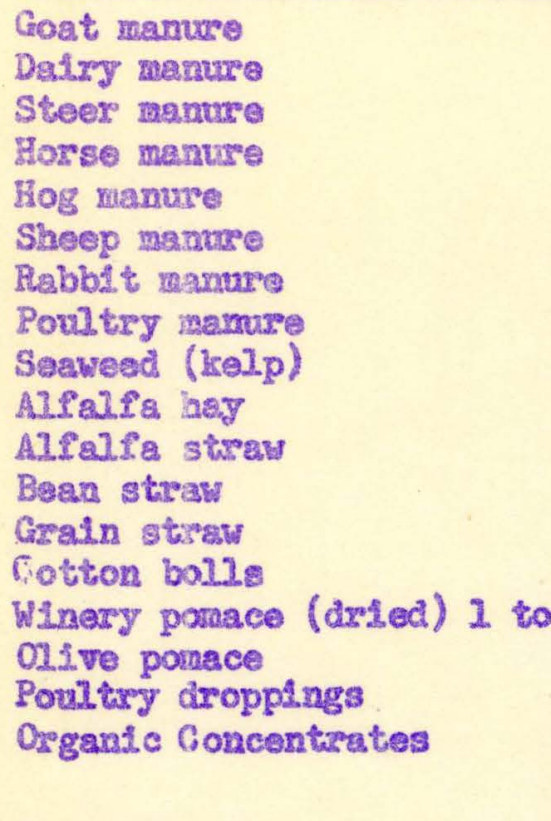 & 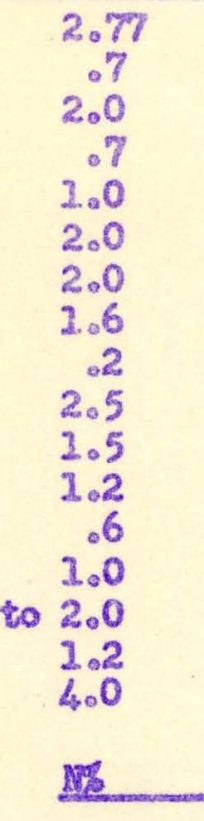 & $\begin{array}{r}1.78 \\
.30 \\
.54 \\
.34 \\
.75 \\
1.00 \\
1.33 \\
1.25 \\
.1 \\
.50 \\
.30 \\
.25 \\
.20 \\
.15 \\
1.50 .0 \\
.8 \\
3.2 \\
P_{3} 0 . \% \\
\end{array}$ & $\begin{array}{r}2.88 \\
.65 \\
1.92 \\
.52 \\
.85 \\
2.50 \\
2.20 \\
.9 \\
.6 \\
2.10 \\
1.50 \\
1.25 \\
2.10 \\
4.0 \\
-2.0 \\
2.5 \\
1.9 \\
\\
\end{array}$ & $\begin{array}{l}60 \\
30 \\
60 \\
60 \\
30 \\
60 \\
50 \\
50 \\
80 \\
85 \\
82 \\
82 \\
80 \\
80 \\
80 \\
80 \\
74\end{array}$ & $\begin{array}{l}70 \\
55 \\
70 \\
75 \\
60 \\
70 \\
70 \\
50 \\
= \\
=- \\
= \\
= \\
= \\
= \\
= \\
55\end{array}$ \\
\hline $\begin{array}{l}\text { Dried blood } \\
\text { Fish meal } \\
\text { Septie sindge (digested) } \\
\text { N1troganle } \\
\text { Tankage } \\
\text { Cottonseed meal } \\
\text { Bat grano } \\
\text { Bone meal } \\
\text { Castor porace }\end{array}$ & $\begin{array}{r}13.0 \\
10.4 \\
2.0 \\
6.5 \\
7.0 \\
6.5 \\
13.0 \\
4.1 \\
6.0\end{array}$ & $\begin{array}{l}3.5 \\
5.9 \\
3.01 \\
3.4 \\
8.6 \\
3.0 \\
5.0 \\
30.0 \\
2.5 .03\end{array}$ & $\begin{array}{r}- \\
- \\
2.3 \\
1.5 \\
2.0 \\
.0 \\
.5\end{array}$ & & $\begin{array}{l}80 \\
80 \\
50 \\
80 \\
80 \\
80 \\
30 \\
=0 \\
80\end{array}$ \\
\hline
\end{tabular}

Bet guano due to conditions under which it is talcen stcan caves varies widely.

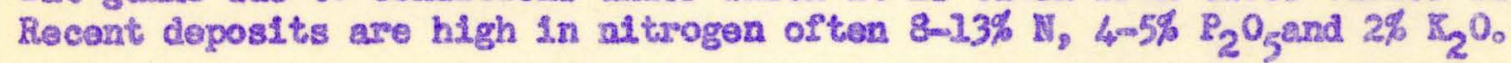

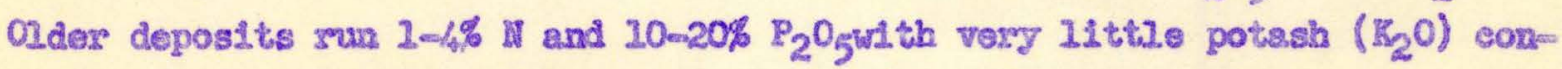
tent. These percentage figures are therefore onily couparative.

AII organic matarlals shoul.d be purchased on the basis of actual anulysis. There is \& uide variation in veine due to molstuse content, type of storege, and other condlthions. The above values are avarages only tairen from oflis cial Litersture.

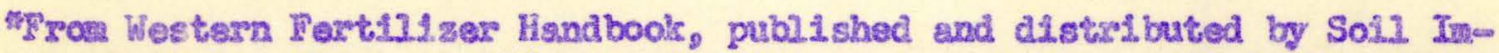
provenent Coranitres, California Fer'111zer Assoeiation, 475 Euntington Ds。 San Marino, California. 


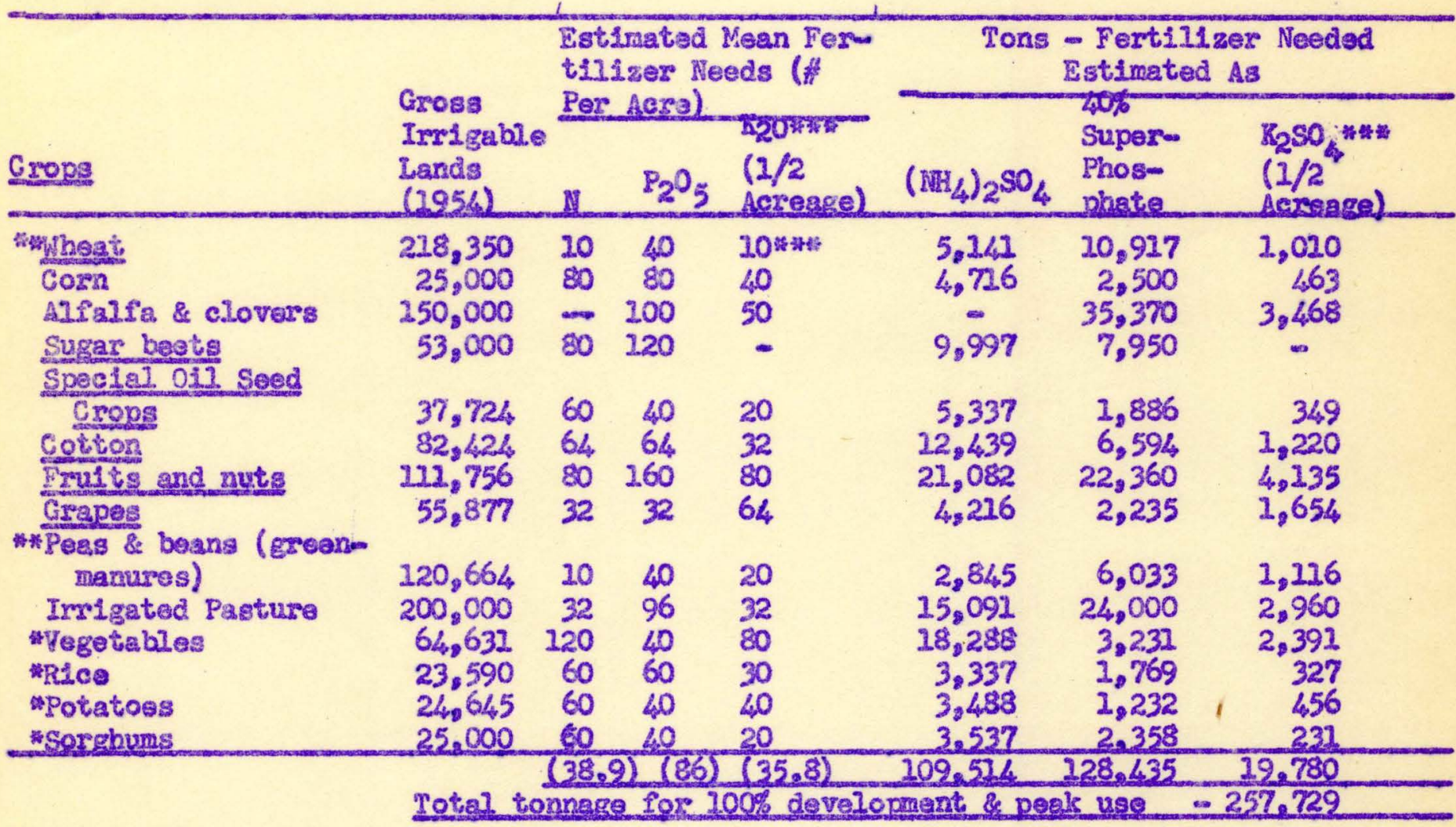

Double Croppling Aeres doubisd cropped Total Crop Acres Total Land Area

316,581
$1,192,651$
876,080

"Acreages of rice, potatoes, vegetables and sorghuns were increased over general report to balance farm family and urban needs.

* Reductione wers made In wheat and pulses to give double cropping of $136 \%$ given in the reporto

\#\#Ptash fertilizars are assuned to be neecled on $1 / 2$ the cropped acreago. (Cagh crops

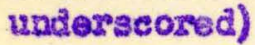


One cannot stress too strongly that a well-engineered Irrigation layout does not guarantee crop production. The advantage is in favor of the farmer who is willing to use it but, by and large, the success of an 1rriggtion devalopment will depend on hov woll the famer understands his problems and undertakes to solve them.

1. Iillage and general farming practices. A number of poor cultural and water use practices contribute as much to low psoduction in Afghanisten as antiquated and inadequate irrigation systems. $F$. O. Youngs in sumarizing his work in Afghanisten had this to say of Afghan faxming practices:

1. "Selection of Crops and Good Seed. Next to adequate water supply, drainage and high fertility, proper geloct1on of exops is most importanto By this Is meant growing the kinds of crops that will be most productive and valuable and by using the best varieties and the highest quality of seed. For food erops, im proved vaxieties of wheet, corn, sweet corn, vegetables, potatoos, sweet potatoes and peanuts will be very valvable. Cotton, sugar beets and tobeceo will be valuable money crops. Alfalfa and clovers will make it possible to produce more and botter 1fveatock and livestock products. Multiplication of seed of good proven varieties will be an important part of the agricultural developmont program (Note: Afghan corn produces $1 / 4-1 / 2$ of Anerican varieties given similar treatment).

2. Improved Methods of Planting and Imfgation. Low ylelds of cropa com monly grown by farmers in the Helmand Vailey are due, to an important extent, to poor methods of planting, Irxigation and evitivation. Both corn and cotton are commonly sown broadcast and irtigated by looding of basins. According to experiments as well as field experience, these crops usually do much better when planted in rows on rldges and Irrigated by furrows. It has been leamed, however, that ridge plantIng and furrow 1rrigation of crops or trees is very poor practice (if carried on cono timuously) on saline goils and is safe only where the salinity problem is negligibie. The thorough leaching out of salts by liberal irxigation in flat basins is essential to prepare salino soils for crop production, or growing of trees。

3. Control of Weods. Insects and Plant Diseaseg. Weeds are becoming a serious threat to agriculture in the Helnand Valley: their control is inperative. Cultivation is consplcuous by 1 ts absence in most of the Ilelds of Afghan farmers In the Helmand Valley. Only a fow of the vegetable crops are commonly grown In rows. In such crops as wheat, corn and cotton, which are sown broadcast, the weods are sometimes purled by hand. (In most fields woeds grow vithout control). Rou planting of crops would allow cultivation and hoeing to control weeds. Chemical sprays should be trded to control troublesone woeds such as camel thorn. (Every farmer should bo taught how to use aimple farm tools which be and his oxen can handle but which are an improvenent over those he now ouns.)

Locusts are a frequent threat to growing crops in the Helmand Valley. Army worms, cabbage worms, aphids, and melon ILIes have also done much danage. Various oprays and poison baits should be used at critical times。 
Such disesses as wheat swut and rust occus in certain years of unusualy high bunidity. Selection of resistent varietios and gtrains is neededo According to sane observations, a few of tho Amerlcan struins appear to be more resistant than most Afghan wheats, although the latter may be better adapted to conditions in the drier yoars.

4. Improvement of Farming in 01der Areas. It seems that unch greater emphesis should be placed on inprovomont of agriculture in the areas where farming has been carrled on for long periods. The farmers in gome of these areas are already taklng advantages of the increased and stabilized water supply resulting from the building of the Arghandab and Kajakai dams and the now canals. They can raise a larger acreage and a wider variety of crops, obtain higher yields and make a highor Income from the land; but they need help in the way of better seed, better 11vestock, and instructions in improved farming practices in order to take full advantage of the Improved water supply.

5. (Management of Irrigation Distriets). These problems are physical, Including adverse conditions of soil, salinity and drainage, and a clinate in which no farming is possible without irrigetion and adrolnistrative, including proper selection and allotment of land, selection of settlers to farm the land and providing housing, implements, seed, livestock and capital until the famers can becone self supporting. Also, the operation and maintenence of dams, canals and water distribus tion and drainage systems is a major problem and proper control of the use of wator on the land is a crying need."

\section{Wator Managoment.}

a. Present conditions - Water use and water management as commonly pracm ticed in Afghanistan operates at $\mathrm{a}$ very low efficlency. Much of the cause is the inadequate, makeshift, irrigation systems which have been in comon use for centuries. Among some of the practices leading to waste of water are

(1) Brush and loose stone diversions which go out with each Ilood causing loss of irrigation water and damage to exops oven when ample supplies are ava17able;

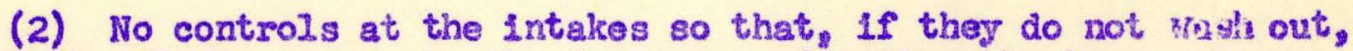
large uncontrollable flows pass on to the farn areas flooding the lower places washing out ditches, damaging crops and adding to ground water already high frovo over irrigation.

(3) Over-exaggereted 1ndependence of individuals, villages, clans and tribes which leads to construction of parallel systems from the river inward - as many as 6 to 10 main ditches, each with 1 ts own brugh and rock diversion, bave bsen observed running parallel and almost touching esch other for miles. There is trea rendous water loss through breaks and seepage from these ditches.

(4) Inproper grades, unilned ehannols through gravally and sandy stretches, substitution of winding channels for checkdrops, and the generally 100 se unbonded, uncompacted banks of these hand dug ditches leads to trenendous seopege loses:

(5) Lack of weed and brush control so that large amounts of water is used by regetation along the numerous eanals and ditches.

(6) An exaggerated application of the riparian principles of water allocation - first come, take all practice - leads to waste on the upper reaches and acute shortages on the lower reaches of any system. An example that is having an 
over.ly eraphasized effect on long range planning occured In 1955 on the Arghandab. This was the driest water year on record, also the year when TarnakoArghandab development was being discussed between agencies and countries. People on the lower ends of the extremely long winding ditches and down the Arghandab were short of water. At the same time the Patow and Zangigar ditches were taking in a lion's share of the water - mach more than they could possibly use efficiently. So the cry "Water shortage" went up and even some Americans turned against further oxpansion of land areas into the Tarnak thinking that the 1955 year was a demonstration of acute water shortage. Impartial studies show it would have been a short water year had all three project areas been fully developed. About $1 / 4$ of all the years of rainfall - zunofi records indicate a low (60-70\%) supply. For the land cultivated in 1955, however, there was adequate water - Inefficient use and distribution as described above made an otherwise adequate supply seern insufficlent for crop needs. The coincidence of the 1955 water use experience with Tarnak development proposals is the principal reason for delays in completion of the Tarnak system. This is despite undisputable proof of abundant water seven years out of 10 and falr assurance 14 of 19 with $60 \mathrm{~m} 70 \%$ of that needed in the ramaining $25 \mathrm{~m} 30 \%$ of the years.

(7) Farm irriggtion is generally hephezard and carelessly done where water supplies are abundant - this leads to great wastage through surface runoff and percolation Into the ground water table. A so called mbasin system is used by the Afghans. Properly laid out and properly irrigated the contour basin system could be highly efflcient. However, the Afghan practice is to let the water mun continuously through all the small ixregular checks or basins until the lower ends are reached. It is more a system of wilderlooding with checks. As a consequence serjous over Irrigation occurs on the upper parts of flalds - the last checks may not get enough. Attempts were made at Nadei-Ali to take a vary simple step forward by placing a small feeder ditch botween rows of check basins so that by irrigating IIrst from the lower and and in turn beck to the head ditch each besin could be properly filled and there would be little wastage. Some few farmers have caught the idea. An Irrigation officlency chock made in 1956 revealed, however, that most farmers had gone back to theix old ways or else were filling all basins to overflowing regardless of soil needs. Irrigation efficiencies were on the order of 20-25\%. Demonstrations made for the farners using their own facillties proved that, where the farm ditches and border feeder ditches were in good state of repair, 60-80\% farm Irrigation efficiency could be obtained even on Nad-I-Al1 solls.

(8) Water irxigation schedules and water allocations are seldom heard of except as arranged by"bakshish" (bribery), "jang-jang" (f1sticuffs) and "ab-ilamdadan" (downrlght vandallsm)。 In the Nad-1-Alis where a sound rotation irrigation schedule and water allocation plan could have greatly reduced water losses and ground water troubles, the three malpractices described above becane so prevalent that three ICA water engineers spent thel $x$ entire contracts in the area and failed to get a water nanagenent program. Every farmer and every village chief wants the water running continuously by his door - he seens to think he has been provided with a permanent stream to be his own. Since these are all urlined, earthen ditches the water 1053 is very high on and the high water tables reflect this misuse of an irrigation system.

b. Improvement of water use prectices. Contrary to the practices described above some very highly efficient use of weter has been observed where karezes of low capacity have been the only source of water for farm areas. One second-foot has been reported to serve $100-150$ acres under such conditions. 
It is recognized that obtalning efficient use of water will be a long hard. struggle. Education, demonstration, organization and enforcenent of regulations wi11 require years to put into operatione Frobably the most effective control would be to set up allocations and sell the water to the farmer. Calculated farm delivexy requirements could be sold at a nominal figure - any excess water used should require a stiff fee. This would require measuring devices, use-records and a system of ditch management that would take a long time to perfect. The Afghan farmer, if made to realize that each excess acro-foot used would cost hin a stiff foe, would by nature reduce his water usage and be more receptive to learning ways and means of conserving water. Reverues badly needed for operation and maintenance could come from water-right assesaments. The joint agency comnittee which reviewed and approved the allocation of water to the Tarnak Atrea $1 /$, made the following recomendations which apply generally to all of S. Wo Afghanistan:

(1) Construction of controlled intakes at all major diversionss

(2) Combining of many of the parallel ditiches。

(3) Construction of proportional dividers where several ditches are supplies from a comon eanal.

(4) Construction of wagteways at tall end of ditches.

(5) Rehabilitation or relocation of amall stretches of canals.

(6) Construction of culverts or overpssses for surface drainage crosglngs。

(7) Repaix of canal baniss.

(8) Lining of leaky canal strotches.

(9) Adjustment of canel capacities according to irxigation requirements。

(10) A complete and efficient irrigation and distribution system, coupled with good water managenent on all lands.

(11) Adequate surface and sub-surface system for disposal or reuse of oxcess waters from the land.

(12) Reclamation of saline, alkaline and wet areas。

(13) Establishment of a crop rotation and eropping system best adapted to each soil class and which is capable of maintalning fertility. tilth and high production of the different soils.

F. O. Youngs adds:

(14) "Establish and put into operation an organization for the proper operation and maintenanco of the entire irrigation and drainage system.

(15) Establish and put into operation an organization to work with the farmers of all areas of the Helmand Valley to tesch and domonstrate the use of improved agricultural and irrigation practices"。

1 Joint committee report of ICA-HVA-MKA and Kaxl O, Kohler, August 4, 1955. 
c. Adapting 1 rrigation systems to sojil conditions. One of the faults of mass land development is the tendency to establish a uniform design on all soll types and slopes. This leads to lack of sufficient capacity for some soils and over design and unnecessary costs on others. Similarly, stressing the use of basin irrigation fails to give proper values to the use of a number of other systems which may locally be most effective for given crops such as row or furrow irrigation for cotton, corn, sugar boets and truck crops, border irrigetion for small grains, contouraborder and broad furrow Irrigation of orchards and the use of corrugations on heavy soils, for sloping pestures, and supplementary to border irrigation. There is/ore best method nor one best design. Each soll type, slope condition and combination of site factors may be best handled by a modification of some sort. Puch of this must be worked out with the farmer on his own land and is beyond the scope of this report. The major characteristics of solls affecting water requirements and irrigation design are summarized here for use.

Several tables have boen prepared from a study of the characteristics of Afo ghanistan soils and application of irrigation principies. $1 / 2 / 23 / 0$

(1) Field interpretation of soil molsture - Many farners Irrigato as soon as a dry crust forvs in the upper $2^{\prime \prime}-4_{4}^{\prime \prime}$ of soll. Actual measurements made in the Nad-i-AII showed less than $1^{n}$ to $1^{\frac{1}{2}}$ intake capacity at the time farmers were putting $4^{n}-6^{n}$ of water into some check basins. Table 62, shows practical. field methods of estimating when soil moisture has dropped low enough to require irrigation. The top four Inches of soll should be ignored except in the early stages of plant growth. This layer dries out quickly under the desert sun and hot winds and usually serves as a mulch. Every effort should be made to eneourage deeper root growth. The $4^{n-18^{n}}$ layer is most eritical layer for irrigation as a large number of plants w111 have $50 \%$ or more of their roots concentrated in this zone and $30 \% \mathrm{~m} 9 \%$ of the nolsture may be extracted from here for different soll depths and textures. The criteria of Table 62 , shorld be applied in such a way as to determine when the $4^{n-18^{n}}$ layer (usually $4^{n}-12^{n}$ ) falls at or glightly below $50 \%$ of field capacity. Irrigation should begin once the $50 \%$ level is passed as some parts of the field may suffer for water if the tep foot is allowed to dry out bem fore 1rrigation begins. The appearance of the plants 1s another and vary good criteria of water needs. Wheat will begin to turn a bluish-green color and the lower leaves beccne harsh and bristiy 19 available water reaches too slow a level. Cotton leaves may becone flaccid or limp on hot afternoons but recover in the cool of the night. If the flaccld condition persists during the night water is definitely needed. Corn leaves cuxi in extremo heat but unfurl and resime their rigldity at night。. If eurling persists through the night water is needed. These are not always exact Indicators as there may be other causes of leaf curl or Ilaccldity. By comparing soil molsture conditions and plant growth one can learn to recognize when irrigation is required.

If Methods for evaluating Irrigation systems, Handbook, 82, U.S.D.A., S.C.S., April, 1956。 $2 /$ Capacity of soll to hold molgture - D. R. Shockley, Agric. Engineer, Feb., 1955 $3 /$ Irrigation (texts) - Houk, Israelson, (others). 
TABLE 62 - PRACTICAI INTERPREYATION CHART FOR SOTI, MOTSTURE

\begin{tabular}{|c|c|c|}
\hline \multirow{3}{*}{$\begin{array}{l}\text { percent } \\
\text { of } \\
\text { RAA } \\
\text { Remainires }\end{array}$} & \multicolumn{2}{|c|}{ Feol or apparance of sol.1s } \\
\hline & 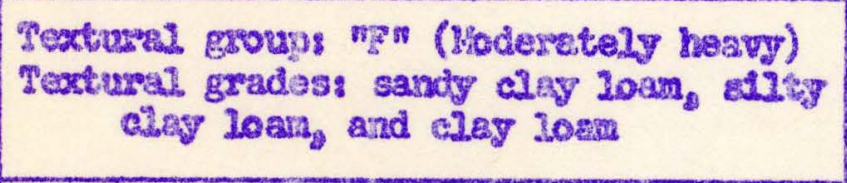 & 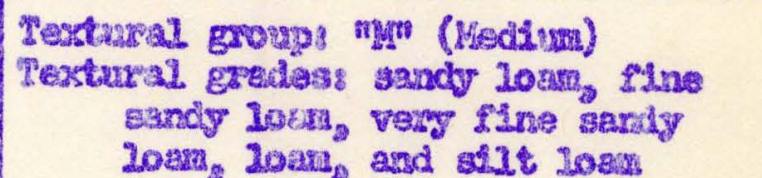 \\
\hline & $\begin{array}{l}\text { Tertural group: H (Heavy) } \\
\text { Testural gredos sandy clay }\end{array}$ & \\
\hline 0 & 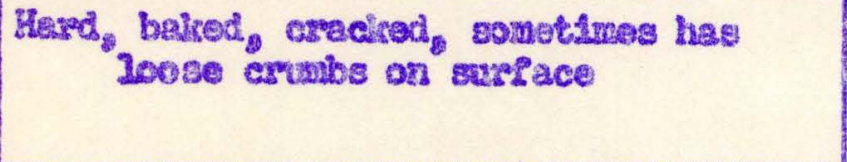 & 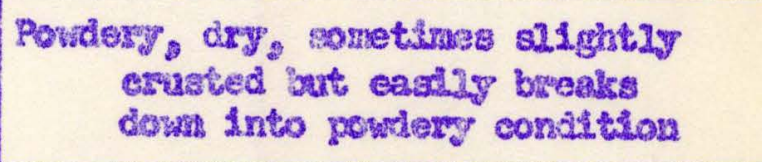 \\
\hline $\begin{array}{l}5005 \\
2088\end{array}$ & 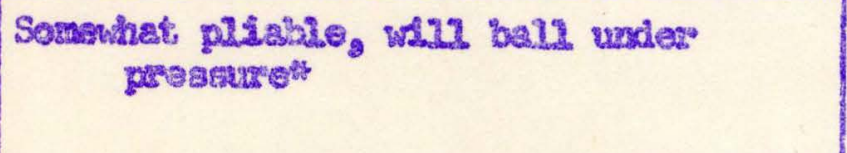 & 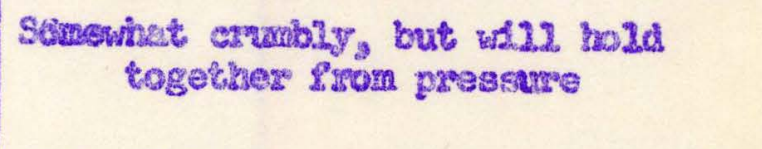 \\
\hline $50-75$ & 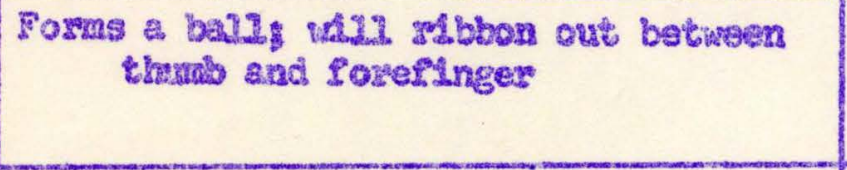 & 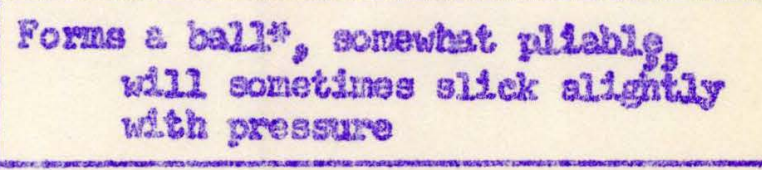 \\
\hline $\begin{array}{l}75 \text { to } \\
\text { ciold } \\
\text { capacity }\end{array}$ & $\begin{array}{l}\text { Esility rabbons out between Plngers: } \\
\text { hes a sllek leoling }\end{array}$ & 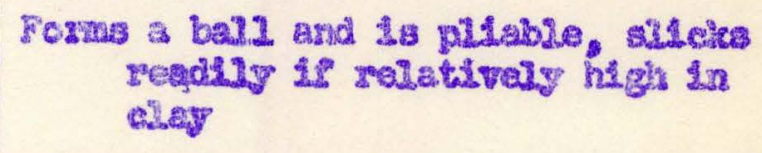 \\
\hline $\begin{array}{l}\text { At rleld } \\
\text { capsostaty }\end{array}$ & 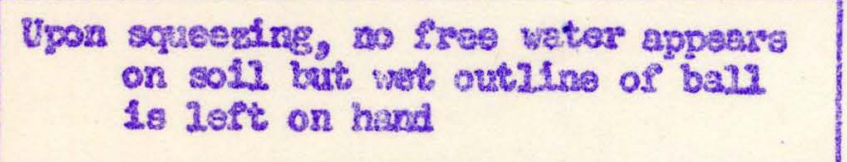 & Same aะ "F" groug \\
\hline $\begin{array}{l}\text { Above } \\
\text { sleld } \\
\text { capactigy }\end{array}$ & $\begin{array}{l}\text { Puddies and free rater forms ox } \\
\text { surface }\end{array}$ & Can squese ont sree wates \\
\hline
\end{tabular}

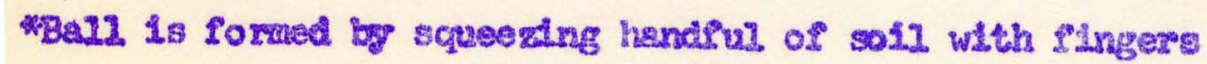


(2) Irrigation unit stream - The amount or head of water required to properly irrigate a strip of land depends on the eapacity of the area to hold water, the rates of intake (initiel and final), the slope, method of irrigation and resistance to Ilow of vegetation and ground surface. Three basic soil factors which can be used for Irrigation design are the rate of Intake, the water-holding capaeity and the slope. Since the general average slope of most Afghanistan projects is sbout .001, the following tables are computed to this grade. Adrugtmenis can be made for other slopes as needed. Table 63, gives the unit streams $1 / 2$ required for proper irxigation of the major soll textures with different soil capacities at 1rrigation time. The lnfiltration rates and soll intake capacities are taken from fleld and laboretory data. The typical symbols used on the maps are indicated in the Iirst colunn. Unit streams less than.001 or over 0.05 are more diffievit to manage by surface irzigation and from a practical standpolnt should be avoided. Table 64: shows the minimum time of applieation for different water intake capacities of soils and different unit streams. These are minimum times only. The efficiency with $w$ hich irrigation is applied will determine the actual irrigation time. Here again irrigation time less than 10 minutes or over 16 hours per border, check or basin becomes a more difficult operation and should be avolded.

(3) Bordes 1rroigation - Whether irrigating by borders or border check basing the date in Table 65, will apply. Here for the rnajor soll groups mapped in S. W. Afghanistan are brought together the TRAM (total readily avallable moisture capacity) and basic intake rates. For these combinations are given the more practical borcler widths and lengths and border gtreams for efficient irrigation. Again the time shown is minimum time and will need to be divided by farm Irrigation efficiency to obtain total time. The borders are all calculated as multiples or uniform fractions of jiribs to make it easier for computing Afghan farm units and farn delivery requirements, Table 66. Where less than 10 minutes minimu irrigation time is indicated sprinkler irrigation would give batter control of water. Where over 16 hours winimum IrTlgation tine is Indicated flooding of rotaining basins may bo the most practical.

These data will help the designer to layout the bost system for each land type and still maintain standard sizes suitable fox laying out Afghan farrn units。 The important thing to note here 13 that a loany sand soli will require, say a 3 cusec head for a $10 \times 100$ meter border and 26 vinutes mininum irrigation time while a deep silty clay loan may ixrigate best on a 25 meter $x 300$ meter bordar with a 0.70 cusec head. Large ditches for high heads and short runs must be avail able to the sandy land farmer, whoreas meller dItchos 8 and longer runs work best for the fermer on the tighter soils.

If proper attention is given to theae Important sol] differences in the layout of farm imlgation systems and If the 1rrigation wator management practices dese cribed In this chapter are adhered to much of the present waterlogging and salinizos Ing of lands can be reduced. Water formerly wasted can be used to give more uniform Irrigation or extended to new lands. Each acre-foot of water wested could be worth 15 bushels of wheat or 1,000 Afghanis if made avallable for plant growh.

1 Unit strean : head In efs for land strip 100 foet long and 1 foot wide。 
Unit Streams for each basic inilltration rate and root zone or Soll Waterholding Capac1ty for Slope of .001

\begin{tabular}{|c|c|c|c|c|}
\hline \multirow[b]{2}{*}{ mbol } & \multirow{2}{*}{$\begin{array}{l}\text { Solle } \\
\text { Texiural } \\
\text { Grouns }\end{array}$} & \multirow{2}{*}{\multicolumn{2}{|c|}{$\begin{array}{l}\text { Basio } \\
\text { Intake } \\
\text { Rates }\end{array}$}} & JRaM Volues or Soli Cepacity at Irrigation IIrae \\
\hline & & & & (1) \\
\hline \multirow[t]{2}{*}{6} & Med. Sands & H. & 8.0 & $12200,1600.1160,0840,0615,0470 \ldots$ \\
\hline & & & 5.0 & $.1400 .1015,0780.0540 .0425 .0315 \cdots \cdots$ \\
\hline \multirow[t]{3}{*}{$\sqrt{5}$} & Loany Sands & [H] & 4.0 & $1.1088 .0800 .0580 .0435 \quad 0315.0235 .0175 \ldots$ \\
\hline & & & 2.5 & $.0690 .0500 .036 \quad .0270 .0195 .0145 .0108 \ldots$ \\
\hline & & 2 & 9.5 & $1.0400 .0300 .0220 .0160 .0120 .0088 .0065 \ldots$ \\
\hline \multirow[t]{3}{*}{4} & Sandy Loams & [H] & 2.5 & $.0690 .0500 .0360 .0270 .0195 .0245 \quad 0108.0079 .0058$ am a \\
\hline & & & 1.0 & $0270.0200 .0145 .0110 .0078 .0058 \cdot n / 3.0032 .0024=\infty$ \\
\hline & & L & .75 & $.0220 .0245 .2090 .0800 .0058 .0043 .0032 .0023 .0017 \ldots$ \\
\hline \multirow[t]{3}{*}{$\sqrt{3}$} & Medo Texts. & H. & 1.5 & $.0400,0300,0220,0160,0120,0088.0065,0048.0036,0026 \ldots$ \\
\hline & & A & .50 & .0235 .0100 .0073 .0055 .0038 .0029 .0021 .0016 .0012 .0008 =- \\
\hline & & 1 & .25 & $.0068 .0050 .0035 .0028 .0020 .0014 .0010 .0008 .0006 .0004=$ \\
\hline \multirow[t]{3}{*}{2} & Mod & (I) & .50 & $.0135 .0100 .0073 .0055 .0038 .0029 .0021 .0016 .0012 .0008 .0006=$ \\
\hline & Textures & A & .25 & $.0068 .0050 .0035 .0028 .0020 .0014 .0010 .0008 .0006 .0004 .0003=$ \\
\hline & & I & 15 & $.0040 .0029 .0022 .0016 .0015 .0008,0006.0004 .0003,0002.00027=$ \\
\hline \multirow[t]{3}{*}{ \& $\nabla /$} & & H. & .25 & $.0068,0050,0035,0028,0020,0014,0010,0008,0006,0004,0003.0002$ \\
\hline & Textures & A. & .20 & 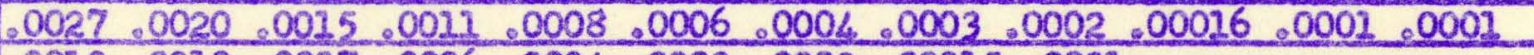 \\
\hline & & & .05 & $.0013 .0010 .0007 .0006 .0004 .0003 .0002,00015.0001 \cdots$ \\
\hline $3 V^{2}$ & & H. & .20 & $.0054 .0040 .0030,0025.0016,0011.0008,0006,0004.0003 .0002 .0002$ \\
\hline \multirow[t]{2}{*}{ PS5) } & $1 \mathrm{kal1}$ & A & .04 & $.0011,0080.0006,0004,0003.0002 .00016,0001 \cdots$ \\
\hline & & & .02 & $.0005 .0004 .0003,0002,00015,0001 \cdots$ \\
\hline
\end{tabular}

- Average high infiltration values, A $=$ Average and L \& Average low values. 
Time to apply various amounts of wato: with various unit stroems

\begin{tabular}{|c|c|c|c|c|c|c|c|c|c|c|c|c|c|}
\hline \multirow{3}{*}{$\begin{array}{c}\text { Unit stream } \\
\text { cfs per } \\
100 \text { ft. long. } 1 \text { ft. }\end{array}$} & \multicolumn{13}{|c|}{ I $2 m e$ in mantes and houx } \\
\hline & 37 & $2^{\text {th }}$ & $3^{n}$ & $4^{n}$ & $5^{\tan }$ & $6^{m}-1$ & $F^{3}$ & $8 \pi$ & gen & & $10^{n}$ & $27^{31}$ & $12^{40}$ \\
\hline & $\min _{0}$ & $\min$ & $\min =$ & $\mathrm{mln}_{0}$ & $m x_{2}$ & mins: & mine. & mino & nin. & & mine & mins. & mine \\
\hline 0.15 & 0.92 & 2.84 & 2.76 & 3.67 & 4.59 & 5.52 & 6.43 & 7.35 & 8.27 & & 9.19 & 10.10 & 21.02 \\
\hline 0.125 & 1.19 & 2040 & 3.59 & 4.79 & 5.98 & 7.18 & 8.38 & 9.58 & 10.77 & & 21.97 & 23.17 & 14.37 \\
\hline 0.10 & 104 & 2.75 & 4.2 .3 & 5.52 & 6.88 & 8.26 & 9.64 & 11.02 & 1204 & & 13.78 & 15.15 & 16.53 \\
\hline 0.075 & 1.86 & 3.72 & 5.55 & 7.44 & 9.28 & 17.10 & 13.85 & 24.9 & 16.65 & & 28.36 & 20.46 & 22.2 \\
\hline 0.050 & 2.76 & 5.52 & 8,28 & 21.04 & 13.8 & 26.56 & 19.32 & 2203 & 24.8 & & 27.6 & 30.36 & 3301 \\
\hline 0.025 & 5.5 & 11.0 & 16.50 & 22.0 & 27.5 & 33.0 & 38,5 & 440 & 49.5 & & 55.0 & $1 \mathrm{Hs}$ & $101 \mathrm{Kr}$ \\
\hline 0.0075 & 18.6 & 37.2 & 55.8 & $2.24 \mathrm{Mrs}$ & $1.55 \mathrm{Hrg}$ & $1.86 \mathrm{Mrs}$ & $2.17 \mathrm{Hr}^{3}$ & $2.68 \mathrm{HP}$ & 2.791 & Hed & $3.1 \mathrm{HSO}$ & $304 \mathrm{Hza}$ & $3.72^{\prime \prime}$ \\
\hline 0.0050 & 27.6 & 55.2 & $1.71 \mathrm{Hrs}$ & $7.83 \quad 11$ & $2.14 \quad 11$ & $30.62 \quad 11$ & $3.98 \quad " 1$ & $3.66 n$ & 4.17 & itis & $428^{\prime}$ & 407 & 6.8411 \\
\hline 0.0025 & 55.0 & $1.83 \mathrm{Mrg}$ & $2075 " 1$ & 3.67 & 4.58 & 5.50 & 6.47 & 7.34 & 8.26 & in & $9.16 \%$ & 10.2 & $11.0 \quad n$ \\
\hline 0,00075 & $3.1 \mathrm{Hrg}$ & 6.211 & 9.30 & 12,4 & 15.5 & 18060 & 21.67 & 24,8 & 27.9 & $n$ & $33.0 \%$ & 34.1 & 37.2 \\
\hline 0.00050 & 4.6 " & 9.2 & 23.8 & 18.4 & 23.0 & 27.6 & 32.15 & 36.8 & 41.4 & $n$ & 46.0 & 50,6 & 558 \\
\hline 0.00025 & $9.16 \%$ & 18.32 & 27.5 & 36.6 & 45.7 & 55.0 & 64.0 & 732 & 82.3 & 11 & 91.4 & 200.5 & 120.0 \\
\hline 0.0002 & $23 \quad 11$ & 46 & 70 & 92.0 & 175 & 240 & 163 & 184 & 207 & 18 & 230 & 253 & 280.0 \\
\hline
\end{tabular}

Reference: Agriculturel Handbook No. 82, U.S.D.A. SCS, Apr.11, 1956. 
TABLS

Julg 15, 1957

SUCGESTED PRACTICAL BORDER SIZZS FOR AFGHAN FARM UNTIS

(Fractions of jiribes) *

\begin{tabular}{|c|c|c|c|c|c|}
\hline \multicolumn{2}{|c|}{ BORDFR WIDTHS } & 5 METTERS & 10 METSEAS & 15 METERS & 20 NETERS \\
\hline $\begin{array}{l}\text { Border } \\
\text { Length }\end{array}$ & & $\begin{array}{l}\text { Area } \\
\text { Jiribos } \\
\text { Acres }\end{array}$ & $\begin{array}{l}\text { Area } \\
\text { Jiribes } \\
\text { Acres }\end{array}$ & $\begin{array}{l}\text { Area } \\
\text { Jiribes } \\
\text { Acres }\end{array}$ & $\begin{array}{l}\text { Arrea } \\
\text { Jiribes } \\
\text { Acres }\end{array}$ \\
\hline $\begin{array}{l}\text { Meter: } \\
50\end{array}$ & jiribes & $\begin{array}{l}1 / 8 \\
0.06\end{array}$ & $\begin{array}{l}1 / 4 \\
0.1235\end{array}$ & & \\
\hline 100 & $\begin{array}{l}\text { jiribes } \\
\text { acres }\end{array}$ & $\begin{array}{l}1 / 4 \\
0.1235\end{array}$ & $\begin{array}{l}1 / 2 \\
0.247\end{array}$ & $\begin{array}{l}3 / 4 \\
0.37\end{array}$ & \\
\hline 200 & $\begin{array}{l}\text { jílbes } \\
\text { acres }\end{array}$ & $\begin{array}{l}1 / 2 \\
0.2147\end{array}$ & & $\begin{array}{l}11 / 2 \\
0.711\end{array}$ & \\
\hline 250 & $\begin{array}{l}\text { j1ribes } \\
\text { geres }\end{array}$ & $\begin{array}{l}2 / 3 \\
0.309\end{array}$ & $\begin{array}{l}11 / 4 \\
0.617\end{array}$ & $\begin{array}{l}19 / 10 \\
0.926\end{array}$ & $\begin{array}{l}21 / 2 \\
1.235\end{array}$ \\
\hline 300 & $\begin{array}{l}\text { jiribes } \\
\text { acres }\end{array}$ & & $\begin{array}{ll}1 & 1 / 2 \\
0 & 741\end{array}$ & $21 / 4$ & \\
\hline 400 & $\begin{array}{l}\text { j1ribes } \\
\text { acress }\end{array}$ & & $\begin{array}{l}2 \\
0.988\end{array}$ & $\begin{array}{l}3.482 \\
1.482\end{array}$ & $\begin{array}{l}4.976 \\
1.976\end{array}$ \\
\hline
\end{tabular}

* Sandier solls require shorter runs and/or narrow borders, heavler soils can be Irrigated with longer runs and wider borders.

\section{GORROGATIONS AND FURROWS}

Each farmer must learn by trial the best layout for his solis. Some general recommendations made by the Soll Conservetion Service (U.S.D.A. Leaflet 343, Dec. 1954) are as follows:

Heavy Solis

Medium Soits

Iight Solls

\begin{tabular}{|c|c|c|c|c|c|c|}
\hline & Rov Lene & vereor Space & Row Lengt? & Fumpon Space & Roy Langt? & Furrou Space \\
\hline $\begin{array}{l}\text { Cropostootad deep } \\
\text { Solis }\end{array}$ & 575 Ft。 & $24^{n}$ & $425 \mathrm{Ft}$. & $24^{n}$ & $225 \mathrm{Ft}$ & 18 \\
\hline $\begin{array}{l}\text { Shallow-root- } \\
\text { ed Crops or } \\
\text { shallow solls }\end{array}$ & $400 \mathrm{Ft}$ & $22^{n}$ & $300 \mathrm{Ft}$. & $22 "$ & $150 \mathrm{Ft}$. & $15^{\mathrm{n}}$ \\
\hline
\end{tabular}




\section{CHAPTER VIJT \\ POTENT IAL AGR ICULTURAT DEUELOPMENT \\ AND BCONONY}

Much has already been written about the present and potential production of S. W. Afghanistan. Much more will be written in the future. This is a subject one must approach with temerity since there are no rellable statistics of any sort avallable to guide such a study. In sumarizing the Helmand Valley Surveys, how ever, the present and potential production and relative costs of development dem serve some discussion.

\section{Estimatos of Past and Prosent Production.}

The 1953 presentation to the Exim Bank placed production prior to any development, 1947 level, at $\$ 12,000,000$ annually or about 400 million Afghani. at the rate of exchange prevailing then. An October, 1955 report estimated an increase of $\$ 4,000,000$ ( at 21.266 Afghanis $=\$ 1,00$ ) in annual incore as a result of the development program. In July, 1956, another report sumnarized the effect of the development program on the increased acreage of lands being farmed each year. It was polnted out that from 1950 to 1956 the increase was 122,000 acres more land. in crops each year. Further sssumptions as to possible progress were made (Tabie 67 ) Applyling the same ratio of increased gross production to the 1957 acres as was estimated for 1955 the present anmual benefits of the program would be about $\$ 5,000,000$ annual1y. The Tudor Coumission reported an "average additional. gross incone in the upper Helmand Valley of nearly $\$ 10,000,000$ per year"a This can hardly be justlfled as it would require average ylelds of 21 bushels of wheat per acre on now lands, a jump of $50 \%$ in sumer crops with an averago equal to 27 bushels of corn per acre; and an increase of 7 bushels of wheat par acre on old lands. Tudor then proceeds to state on Page 39, that present wheat yields range from 4-10 bushels (weighted mean of land classes) $=6.8$ bushols and corn yields range from $4-15$, welghted mean $\approx 8.7$ bushels. This hardly bears out the very high annual benefits stated in the preamble of the report.

In none of these former studies had an attempt been made to rationalize the various reports on population, food production, food consumption, imports, exports and wage scales. This was done in Chapter II of this report where it was pointed out that the figure of $3,000,000$ population for S. W. Afghanistan cannot be reconclied with known production and land areas. A sinilar situation was true of livestock population reports. By a serles of analyses that correlated the various reports and survey deta it was possible to arrive at a population in the entire watershed of $1,500,000$. The crop and livestock gross production values were est1mated at $\$ 24,400,000$ and $\$ 10,350,000$, respectively, or a total gross agricultural production of nearly $\$ 35,000,000$. The total irrigated Iand area to reach this production was estimated at 795,000 acres. This would include all lands on the watersheds ylelding runoff into the Chakansur-Siestan siniks or about $1 / 2$ of the country. Since the arses used in forner reports was principally below the two reservolrs the acreage would be about $48 \%$ of the total estimated (Tables 17 \& 18) and the proportional gross product about $\$ 17,000,000$ which correlates with the original production estinate of $\$ 12,000,000$ and the $\$ 5,000,000$ increased produco tion due to development. 
The annual per capita value of products fron these studies was calculated to 985 Afghanls. This is somewhat in line with Tudor's estimate of 1,000 Afghanis for the country as a whole.

\section{Surveys of Presently Irrigated and Potentjaliy Irrigable Lands.}

As shown in Chapter I, Table $I_{\text {g }}$ about $1,600,000$ acres have been surveyed in attempts to locate suitable lands for irrigation. Another 1,500,000 has been examined by rapid, aerial or other methods. The location of areas surveyed, briefly examined or reported are given in Table 68 . together with their location, gross acreage, and the presently cultivated and potentially irrigable acreage. Those whlch have been surveyed are marked by an asterisk. The others have been seen only briefly or are measured from aerial photos.

The 1953 report estimate/bused on very 1 imfted surveys and a rapid aerial reconnalssance of the country that about 820,000 gross acres of irrigable and reclaimable lands lay within command of the Helmand-Arghandab System with 245,000 acres in use at the time. The land classes were estimated at I $=18.8 \%$, II $=23.8 \%$, III $=23.6 \%$ and IV $=33.8 \%$. The latest summary of the 12 projects surveyed indicates 700,000 acres gross irrigable or reclaimable lands with a potential land class distribution of approximately, I $\approx 12.6 \%$, II $\equiv 26.1 \%$, III $=49.7 \%$, and IV $=$ 11. $6 \%$. The surmary of land classes for these areas is given in Table 69.

A map of S. W. Afghanistan projects has been prepared to show all potential land areas of any importance. (Drawing LD-17-R4). The legend shows for each area the potentially irrigable and presently cultivated land, the sources of irrigation water and the relative adequacy of supply over $1,155,000$ acres are shown as having some agricultural use potentia?. about 343,000 acres were formerly used for irrigation. Now about 475,000 would be in use within this area.

It can be seen, therefore, that these lands and the Helmand-Arghandab and other streams dvaining to the Chakansur-Siestan Basin compose a great national resource for Afghanistan. A water resource of $12,000,000$ acre-feet annually and a land resource of over one million acres compares with the Columbia River Basin in southwest part of the State of Washington in the United States.

\section{Costs of Developnent.}

Again, it must be emphasized that the estimates presented here are not to be assumed as concrete figures for contractual purposes, even though as much data as can be obtained on present and projected costs of development are included. The principal purpose is to provide some sort of yardstick for measuring the total job of land and water resource development, its possible ultimate development cost and to make a comparison of costs with expected returns from agricultural production.

Table 38 projects. Table 70 ed summarizes the estimates made by ACU as to their work and the farmers" contributions. The latest summary of costs was made at the time of the Tudor Commision's short trip to Afghanisten. These figures are presented in Table 1 


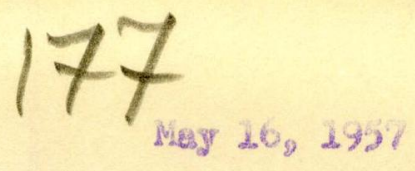

Teble 68

S. W. ARGHAMISTAN IRRTGABLE LAMD ABEAS

\begin{tabular}{|c|c|c|c|c|c|}
\hline AREA MAME & 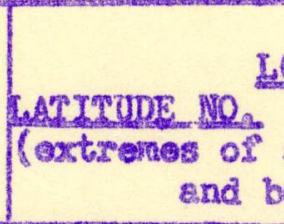 & $\begin{array}{l}\text { AYTON } \\
\text { LONCTTUDS EASP } \\
\text { mas, not noets } \\
\text { mas) }\end{array}$ & GR, & $\frac{\text { CULT PRIOR }}{\text { TO DEV PROG }}$ & $\begin{array}{c}\frac{\text { NGF POIEN }}{\text { TALIX IRZ }} \\
\text { Acres }\end{array}$ \\
\hline Arghandab. $\mathrm{C}_{\text {. }}$ & $\mid \begin{array}{lll}32^{\circ} & 25^{\circ} & 30^{\circ} \\
31^{\circ} & 42^{\circ} & 50^{\circ}\end{array}$ & $\begin{array}{lll}65^{\circ} & 13^{\circ} & 50^{\circ} \\
65^{\circ} & 55^{\circ} & 50^{\circ}\end{array}$ & 132,220 & 65,000 & 80,000 \\
\hline Axghandab No & $\begin{array}{lll}31^{\circ} & 28^{\circ} & 50^{\circ} \\
31^{\circ} & 45^{\circ} & 00\end{array}$ & $\begin{array}{lll}65^{\circ} & 10^{\circ} & 00^{\circ} \\
65^{\circ} & 45^{\circ} & 00^{\circ}\end{array}$ & 67.635 & 25,000 & 40,000 \\
\hline Arghandab (Upose) & $\mid \begin{array}{lll}31^{\circ} & 42^{\circ} & 50^{\circ} \\
31^{\circ} & 48^{\circ} & 00^{\circ}\end{array}$ & $\begin{array}{l}65^{\circ} 42^{\circ} \quad 50^{\circ}= \\
65^{\circ} 48^{\circ} \quad 000\end{array}$ & 2,000 & 500 & 1,000 \\
\hline Asghandab (Lower) & $\begin{array}{lll}31^{\circ} & 29^{\circ} & 00^{m} \\
31^{\circ} & 37^{\circ} & 00^{n}\end{array}$ & $\begin{array}{lll}64^{\circ} & 38^{\circ} & 00^{\prime}- \\
65^{\circ} & 13^{\circ} & 00^{m}\end{array}$ & 20.000 & 2,000 & 8,000 \\
\hline Asghastan (0ppor) & $\mid \begin{array}{lll}31^{\circ} & 23^{\prime} & 50^{\circ}-0 \\
33^{\circ} & 00^{\circ} & 00^{\circ}\end{array}$ & $\begin{array}{l}65^{\circ} 34^{\circ} 00^{2} \\
60^{\circ} 00^{\circ} 00^{\circ}\end{array}$ & 200,000 & 25,000 & 60,000 \\
\hline Beksra & {$\left[\begin{array}{lll}31^{\circ} & 55^{\prime} & 00^{\prime \prime} \\
32^{\circ} & 20^{\circ} & 50^{\circ}\end{array}\right.$} & $\begin{array}{lll}62^{\circ} & 30^{1} & 00^{11} \\
63^{\circ} & 25^{1} & 00^{11}\end{array}$ & 350,000 & 2,000 & 125,000 \\
\hline Boghrs (19d-o $1-A] 1)$ & $\mid \begin{array}{lll}31^{\circ} & 34^{\circ} & 44^{\circ} \mathrm{cos} \\
31^{\circ} & 41^{\circ} & 14^{\mathrm{m}}\end{array}$ & $\begin{array}{lll}64^{\circ} & 11^{\circ} & 49^{\circ} \\
60^{\circ} & 18^{\circ} & 47^{\circ}\end{array}$ & 25,000 & none & 18.500 \\
\hline Boghre (out-ol sprod & $\begin{array}{l}31^{\circ} 20^{\circ} 00^{\circ} \\
30^{\circ}\end{array}$ & $\begin{array}{lll}64^{\circ} & 07^{\circ} & 33^{1} \\
64^{\circ} & 18^{\circ} & 45^{\circ}\end{array}$ & 35.000 & none & 8.000 \\
\hline Chakansux & $\begin{array}{lll}30^{\circ} & 32^{\circ} & 00^{\prime} \\
32^{\circ} & 40^{\circ} & 00^{\circ}\end{array}$ & $\begin{array}{lll}60^{\circ} & 55^{\circ} & 00^{\mathrm{m}} \mathrm{ks} \\
62^{\circ} & 20^{\circ} & 00^{m} \\
\end{array}$ & 275,000 & 40,000 & $\begin{array}{c}65,000 \\
(250,000)\end{array}$ \\
\hline Daryeshan & $\begin{array}{lll}30^{\circ} & 33^{\circ} & 50^{\circ} \mathrm{e} \\
31^{\circ} & 09^{\circ} & 34^{\circ}\end{array}$ & $\begin{array}{lll}63^{\circ} & 50^{\circ} & 00^{m} \\
60^{\circ} & 2^{\circ} & 30^{n} \\
\end{array}$ & 73.920 & 6,500 & 45,000 \\
\hline Dord (Jpper) & $\begin{array}{lll}30^{\circ} & 57^{\prime} & 00^{\circ}= \\
32^{\circ} & 20^{\circ} & 00 \%\end{array}$ & $\begin{array}{l}65^{\circ} 54^{\circ} \quad 00^{\circ}= \\
66^{\circ} \quad 45^{\circ} \quad 00{ }^{n}\end{array}$ & 50,000 & 5,000 & \\
\hline Farah (Lower) & $\begin{array}{lll}33^{\circ} & 23^{\prime} & 00^{\mathrm{m}}= \\
3^{\circ} & 05^{\circ} & 00^{\mathrm{m}}\end{array}$ & $\begin{array}{l}61^{\circ} 28^{\circ} 0^{m-1} \\
61^{\circ} 58^{\circ} \quad 00^{m}\end{array}$ & 100,000 & 7.500 & \\
\hline Barah (0ppex) & $\begin{array}{lll}32^{\circ} & 25^{\circ} & 00^{\circ} \\
33^{\circ} & 15^{\circ} & 00^{\circ} \\
\end{array}$ & $\begin{array}{l}62^{\circ} 10^{\circ} 00^{\circ} \\
64^{\circ} 30^{\circ} 00^{\circ}\end{array}$ & 100,000 & & \\
\hline Gaxnsel & $\mid \begin{array}{lll}30^{\circ} & 10^{\circ} & 00^{\circ} \\
30^{\circ} & 35^{\circ} & 00^{\circ}\end{array}$ & $\begin{array}{l}61^{\circ} 48^{1} \quad 00^{m} \\
63^{\circ} 50^{\circ} \quad 0^{\prime \prime}\end{array}$ & 123.800 & 10,000 & \\
\hline Gliglahisshomalem & $\begin{array}{lll}31^{\circ} & 38^{\prime} & 50^{m} \\
31^{\circ} & 50^{1} & 00^{n}\end{array}$ & $\begin{array}{l}64^{\circ} 08^{\circ} 24^{\circ} \mathrm{cos} \\
64^{\circ} 35^{\circ} 00^{\circ}\end{array}$ & 21.000 & 5,000 & $t a$ \\
\hline Gaxutom Adreskand & $\begin{array}{lll}31^{\circ} & 35^{\circ} & 00^{\circ} \\
33^{\circ} & 55^{\circ} & 00^{\circ}\end{array}$ & $\begin{array}{lll}61^{\circ} & 10^{\circ} & 00^{\circ} \\
63^{\circ} & 00^{\circ} & 00\end{array}$ & 200,000 & 5,000 & 0 \\
\hline Gajairaj-Glmishk & $\begin{array}{lll}31^{\circ} & 50^{\circ} & 00^{\circ}- \\
32^{\circ} & 19^{\circ} & 00^{\circ} \\
\end{array}$ & $\begin{array}{l}64^{\circ} 35^{\circ} \quad 00^{10} \mathrm{~m} \\
65^{\circ} 061001 \\
\end{array}$ & 45,000 & 12,500 & \\
\hline Kajakai, Wost & $\begin{array}{lll}32^{\circ} & 19^{\circ} & 00^{m} \\
32^{\circ} & 25^{\circ} & 00^{\circ} \\
\end{array}$ & $\begin{array}{l}65^{\circ} 00^{\circ} \quad 00^{m} \\
65^{\circ} 06^{\circ} \quad 00^{m} \\
\end{array}$ & 12.730 & 50 & \\
\hline Khash & $\begin{array}{lll}31^{\circ} & 00^{\circ} & 00^{\circ} \mathrm{c} \\
32^{\circ} & 10^{\circ} & 00^{\mathrm{m}}\end{array}$ & $\begin{array}{l}62^{\circ} 03^{\circ} 00^{\circ} \mathrm{co} \\
63^{\circ} 25^{\circ} \mathrm{CO}^{\mathrm{m}}\end{array}$ & 250,000 & 20,000 & 75.000 \\
\hline Lhuspas & $\begin{array}{lll}31^{\circ} & 20^{\circ} & 00^{\circ} \\
32^{\circ} & 15^{\circ} & 00^{n}\end{array}$ & $\begin{array}{l}61^{\circ} 55^{\circ} 00^{\circ} \mathrm{er} \\
62^{\circ} 30^{\circ} 00^{\circ}\end{array}$ & 25.000 & 500 & \\
\hline Khnshk-1-liakud & {$\left[\begin{array}{lll}31^{\circ} & 35^{\circ} & 00^{m} \\
31^{\circ} & 50^{\circ} & 00^{m}\end{array}\right.$} & 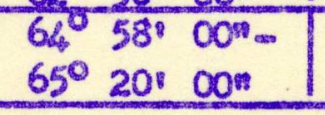 & 25.000 & 4,000 & 7,500 \\
\hline
\end{tabular}




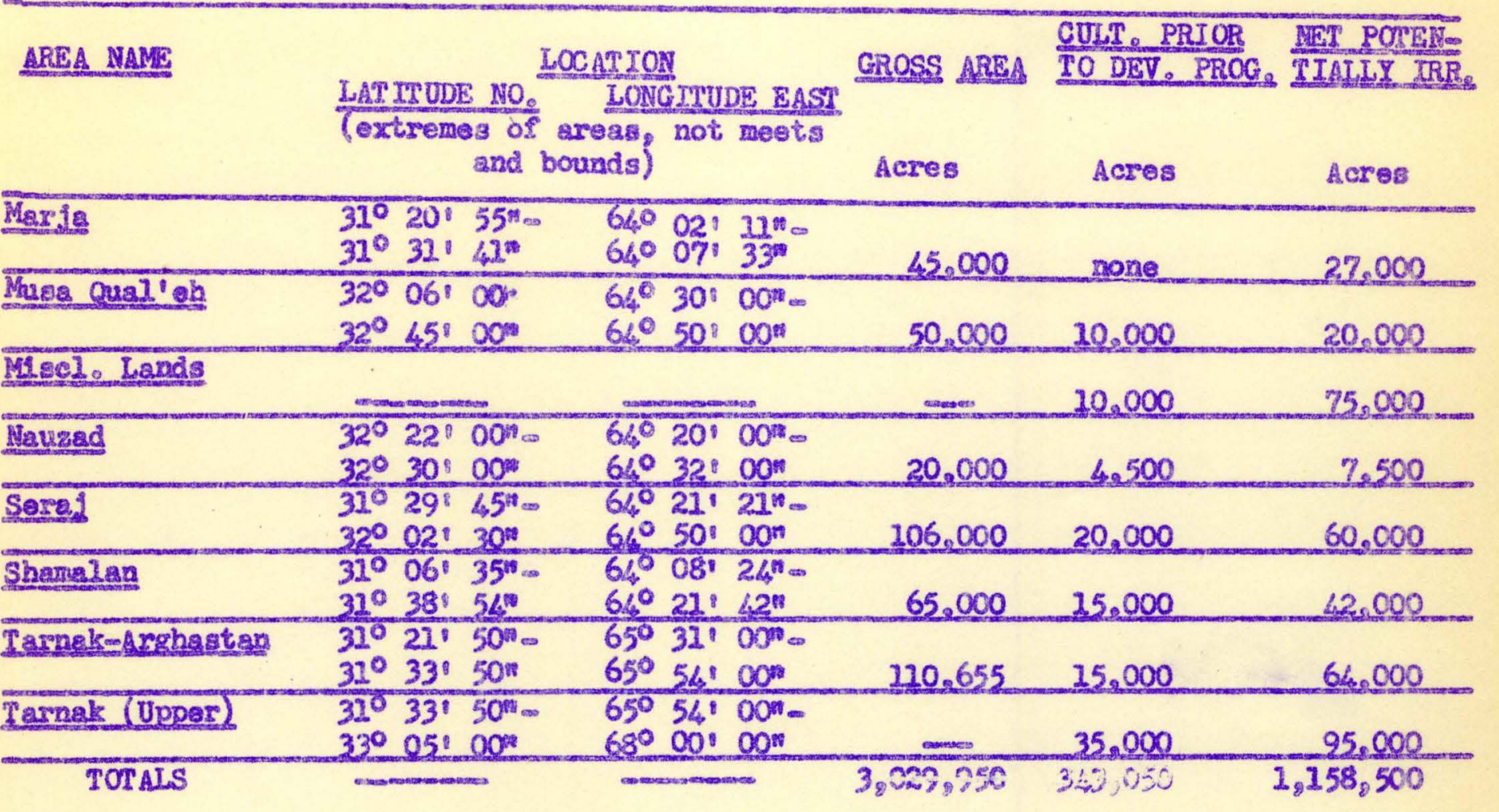


Table 69 SUMMARY OF IRRTGABIE LAND CLASSES - S. W. AFGHANISTAN $8 / 27 / 57$

\begin{tabular}{|c|c|c|c|c|c|c|}
\hline \multirow[b]{2}{*}{ Area } & \multirow{2}{*}{$\begin{array}{l}\text { Gross } \\
\text { Acres in } \\
\text { Project }\end{array}$} & \multicolumn{4}{|c|}{ Net Acres Potentially Irrigable } & \multirow{2}{*}{$\begin{array}{l}\text { Total } \\
\text { Net } \\
\text { Inrolgable }\end{array}$} \\
\hline & & Cless I & Class II & Class II & Class IV & \\
\hline Arghandab, C. & 132,220 & 26,048 & 17,110 & 37,317 & & 80,475 \# \\
\hline Arghandab, N. & 67,635 & 10,208 & 10,057 & 16,288 & 3,680 & 40,233 \\
\hline Bakwa & 350,000 & 17,250 & 34,500 & 46,000 & 17,250 & 115,000 " \\
\hline $\begin{array}{l}\text { Bognra } \\
\text { Chairansure }\end{array}$ & $\begin{array}{r}25,000 \\
554,500\end{array}$ & & $\begin{array}{r}1,531 \\
26.653\end{array}$ & $\begin{array}{l}11,649 \\
69,982\end{array}$ & $\begin{array}{r}5,000 \\
13,365\end{array}$ & $\begin{array}{r}18,180 \\
110,000\end{array}$ \\
\hline Darweshan & 73,910 & 7,492 & 16,411 & 21,230 & 95 & 45,228 \\
\hline Garmael & 123,800 & & 6,038 & 31,417 & 4,333 & 41,788 \\
\hline$W=$ Kajakai & 12,780 & 173 & 6,790 & 430 & 735 & 8,068 \\
\hline Maxja. & 45,000 & & 5,910 & 7,590 & 21,500 & $25,000 *$ \\
\hline Seraj & 106,000 & 3,577 & 10,895 & 29,692 & 18,170 & 62,334 \\
\hline Shemalan & 65,000 & 8,184 & 10,127 & 24,064 & $1,4,3$ & 43,818 \\
\hline Tarnak & 110.655 & 8.936 & 29.649 & 25.768 & & \\
\hline ALL AREAS & & 87.695 & 1768,881 & 320,997 & 174.836 & 646,409 \\
\hline
\end{tabular}

"From previous measurements, not latest maps.

Note:

By agreement with HVA Class IV lands in the C. Arghandab and Tarnak were not to be allotted water. Only that annually cropped in No Arghandab was to recelve water. Only the annually cropped acreage for N. Arghandab is shown. 
Table

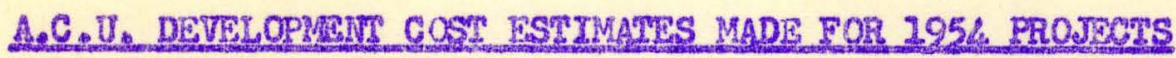

$8 / 28 / 56$

By C. P. Swet?

\begin{tabular}{|c|c|c|c|c|c|}
\hline Area & $\begin{array}{l}\text { Submist. \& } \\
\text { Accumulator } \\
\text { Droing }\end{array}$ & $\begin{array}{l}\text { Ferm } \\
\text { Ditcher }\end{array}$ & Leveling & $\begin{array}{l}\text { Drainage } \\
\text { on Fatrn }\end{array}$ & Josching \\
\hline Darwoshan & $1,018,290$ & 260,300 & $2,000,800$ & $1,308,900$ & 44.735 \\
\hline $\begin{array}{l}\text { Tharalan } \\
\text { Marjas }\end{array}$ & $\begin{array}{l}993,600 \\
618,300\end{array}$ & $\begin{array}{l}157,200 \\
266,200\end{array}$ & $\begin{array}{l}1,495,600 \\
2,099,800\end{array}$ & $\begin{array}{l}2,051,100 \\
1,583,400\end{array}$ & $\begin{array}{l}86,100 \\
89,000\end{array}$ \\
\hline Mad-as-A11 & & & & $2,122,700$ & 56,910 \\
\hline Seray & $\begin{array}{l}1,002,600 \\
3,528,900\end{array}$ & $\begin{array}{l}432,000 \\
659,400\end{array}$ & $\begin{array}{l}2,268,700 \\
9,712,900\end{array}$ & $\begin{array}{l}5,000,000 \\
3,82,500\end{array}$ & $\begin{array}{r}81,300 \\
108,300\end{array}$ \\
\hline 1.. Arghandiab & 560,000 & 279,635 & 910,000 & $1,125,000$ & 123,500 \\
\hline S. Avghandab & $2.253,300$ & -600.000 & $1,200,000$ & 2.262 .110 & 326,600 \\
\hline ToTAYS & 6.974099 & 2.354 .735 & $20,687,700$ & 17.267 .760 & 921.025 \\
\hline
\end{tabular}

T) Lasching work is assumed to be done by the peoplo. It Is 21 so assuned thay will conm tritbute their own labor to complete checke and borders and leval within checks \& borders 
Some changes have been made in the costs of Tarnak and Nad-i-Al1 development, otherwise the data represents roughly what the various interested parties thought the costs were at that time.

While ACU work on farm irrigation and drainage and the peoples contributions to land reclamation reflect some of the jobs to be done in the various projects the data is only relative and may go up or down. Since 130,000 more acres are now annually cropped it is obvious that the famers are doing a great deal of work thenselves. Only 18,300 net in the Nad-i-Ali and some $8,000-10,000$ acres in the Marja have been actually prepared to the final stage of cultivation by government and contractual agencies. On the other hand a great stimulus to agriculture in the whole Arghandab-Helmand area was furnished by the installation of the two reservoirs. As priviously stated in this report, when the Darweshan diversion and Tarnak siphon are completed major water controls serving 270,000 acres will have been put into effect.

In order to arrive at some basis of allocating costs to various land classes a study of HVA land settlement proposals was made. It was decreed by Kabul that land allotments to settlers would be made on the basis of Class $I=7 \frac{1}{2}$ acres or

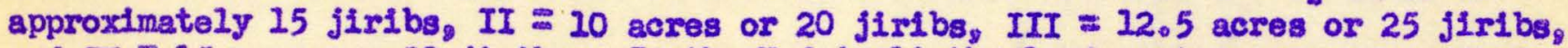
and IV $=15$ acres or $30 \mathrm{jlm}$ bs. In the Nad-1-Ali the land costs were assessed at 9,000 Afghanis per family, housing at 12,000, livestock and seeds at 5,000 and cash advances at 1,000 Afghanis per family. In the Marja the settlers were assessed 800 Afghanis per jirib of Class II, 600 for Class III, and 400 for CIass IV. Loans for housing - 5,000 Afghanis, livestock and farm equipment - 3,000 Afghanis, cash and wheat - 1,000 Afghanis were contemplated. In addition all farmers were to pay 600 Afghanis for water rights and 15 Afghanis annual land tax per jirib. Operation and malntenance charges were to be separate. Table 72 sumarizes these development costs which accrue to each farm fanily as a result of settlement on project lands. These costs are for the most part over and above the construction costs shown in Table 73.

\section{Table 7 PROPOSED DISTRIBUTION OF LAND SETTLEMEIT CHARGES TO SETTLERS $8 / 26 / 57$}

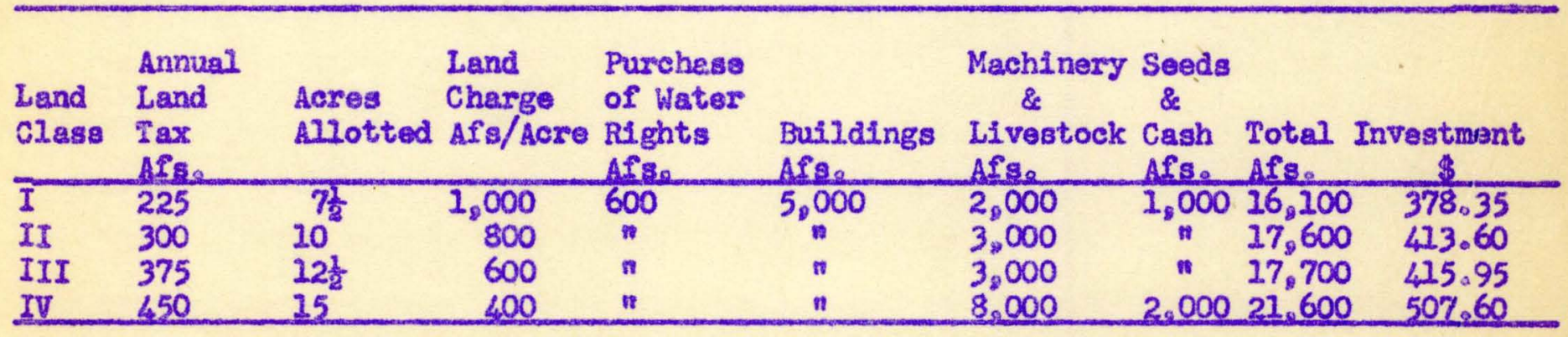




\section{Income Potentials and Relation to Costa.}

Present income has been discrssed above. Present gtandards of I1ving were discussed in Chapter II. The potential production of these projects depends laxgely on what the people do under the stimulus of firm veter, better Irrigation and draine age facilities and governmental and forelgn aid. There is a saying, "The more jou do fur this land the more it will. gros for you".

\section{a. Development Stages。}

When the program vas f1rst outIined in 1953 a series of development stsges were contemplated. Four stages of land development, each adding materially to the productive capacity of a given acre of land were assumed to nornally occur starting from raw land. These were 11sted for arch project in the 1953 roport and an est1mate made of the ecreage that would reach each stage of development each year. Exs planation was given by projects as to the reasons back of the specific ostimates made for each. For many reasons few have progressed as antlclpated although the benefits to date are not far behind estimates when the land areas improved are considered. Below is a brief discussion of the four stages, necessary in developdng the soll and water resources of the area.

Stage 2. A flrm water supply with minimum leveling, drainage and condjtioning of land. To quel1fy, the water supply mist bo adequate throughout the entixe year so that crop rotations and double-cropping is possible. In several areas this has now been accomplished, as in the Shamelan, Nad-i-Ali, upper Central Arghandab, and Marja. Tarnak and Daweshan are being pregeted for fixm water. Improvement in land loveling, drainage, and leaching of salts has made some progress in Marja, Nad-1-Al1, and Shamalan. The farm water distribution system has been improved in Nad-i-Ali and parts of Marja. This work on farm distribution will follow in Tarnak, Central Arghandab and Daweshan when the main canals and laterals have been constructød.

Stage 2. Improved aystems of Irrigation and drainage should be installed follow Ing dovelopment of a dependable supply of vater. This is necessary to insure proper and efficient use of water. Now where solls and drainage surveys have been made, the main drains can be installed at the time of installing the major 1rrigatIon systems. Marja, Nad-1-AI1, Darweshan and Tarnak are following this plan. Iand conditioned properly for effleient use in Stage 2, will be cleared of brush and rocks, leveled to insure even water distribution, leached of harrful salts and seeded Initlally to soll-bullding crops。 Only a fow areas in Marja and Shamalan have reached this atage. On-farm drainage will be completed before the land is considered as qualifled for the second stage of development. No new land has reached this stage in the Helmand Velley. A fow areas in the Shamalan adjacent deep drains are being reclaimed. Substantial inereases in crop production per acre will follow the completion of these steps. This stage of development should normally occur within five years after the flrm water stage, however, Nad-i-AII is still littlo improved after 5 years as far as farri drains are concernod. The use of additional water in some areas may actuajly result in decreased ylelds through rising wates tables with resultant salinization of the soil. The Nad-1-Ali demonstrates the effect of fallure to follow through with farm drains where needed.

Stage 3. Improved crops and land use puts each acre of land to Its best use and puts the best varlety of each crop on the land. Better seed and crop rotations are real ateps forwaxd in production. Improved tillage, planting and harvesting methods will insure better ylelds. It was predicted in 1953 that within ten years after the firm water stage, on-farm and technical assistance programs should have made marked progress on this phase of improvement. Some work is now belng done 
along this line by ICA but results so far are limited.

Stage 4. Maximum production can come only after all of the above steps have been thoroughly and efficiently carried through and use of adequate amounts of fertil1zers and manures has become an established practice. It was predicted in the 1953 report that after 15-20 yesrs a fertilizer industry might start developing in Afghantstan. It was also predicted that stage 4 , of development might be realized from 15-30 years after the assurance of $f^{\prime \prime} \mathrm{rm}$ water ${ }_{\mathrm{s}}$ The few trials made of fer tilizers and green manures have given excellent and promising results. However, large acreages, because of the human factor, may never be developed to their full potential. It appears now that this stage is much farther away than anticipated when the Helmand Valley development program was initiated.

b. Production Potentials and Crop Values.

(1) Grop Production Index.

Studies have been made since 1953 of crop production potentials of various classes of land. There is still very little research on crops, crop management and fertilizer usage in this area. Chapter VI \& VII discussed the major problems of irrigation, soil and crop management and fertility. From various sources data has been brought together on the potential production of various crops on the land classes as described in Chapter IV, and the values of these crops based on local surveys of prices as presented in Table 13 of Chapter II. From these a production-value index has been assembled which can be used to quickly evaluate any combination of crops for any land class. Stage 3 level of development is assumed. This represents the maximum development potential without the extensive use of commercial fertilizers. It is quite possible fertilizers will not be available for a long time in large quantities. In fact little value would come from wide use of fertilizers until stage 3, as described above, has been reached. As of the present thin this level should represent the maximm practical attainment of these projects and can be used to evaluate their relative worth as compared to costs of development. Table 73 ( 3 pages) sets forth the various crops which can be grown, their anticipated ylelds for different classes of land, the value of the crop in Afghanis per jirib and dollars per acre. As can be seen a wide variety of crops are included. The values also range widely for Individual crops depending on the demand for this crop and local market prices. It must be realized of course that demand and price conditions fluctuate widely and that the market possibilities for a given crop should be studied thoroughly before any large production is attempted. In facto processing centers and markets must be established if more than subsistence agriculture is to result from the Helmand Valley development program. Crops likely to bring higher Income and suitable for export include frults and nuts, tobacco, cotton and wool. Crops of high value locally but probably not suitable for export include potatoes, rice, and certain truck crops. 011 seed crops such as castor bean, cotton for seed, soy bean and peanuts could probably be valuable both for local consumption and for processing to export. The relative values of these are hard to determine. Special crops such as olives, cltrus and dates should be studied as to their potential prom duction here. Rlee could serve a useful purpose as a reclamation crop on some moderately heavy deep soils and also furnish a highly favored food product now quite high in price compared to other grain crops.

For comparison of crop yields and prices the $3 \mathrm{rd}$ page shows ylelds and values of crops from all U. S. Reclamation projects for the year, 1955, the Columbia Basin ylelds and prices for the seme year and miscellaneous data on yleld tests of new varieties and production methods at Nad-i-Al1, Lashkarga and Kabul. 
Since these data are averages of all conditions and soil classes they reflect more the expected ylelds shown for Class III lands. Generally the ylelds and values used in the crop production - crop value Index are about $1 / 3$ to $2 / 3$ those shown as the average of $\mathrm{U}$. S. Reclamation Projects.

\section{(2) Production Potentials of Land Settlement Types of Farms,}

The HVA as previously stated set up ariftary limits on land allotments for Classes I-IV. They also recommended certain cropping plans. These are summarized in Table 7, using the crop production index to evaluate gross income. The average per acre returns are Class I - \$109.70, II - \$77.97, III - \$52.73, and IV - \$32.75, (32.534 Afghanis $=\$ 1,00$. When $35 \%$ is deducted for production costs the relative amounts of land to provide equal per capita returns ( 5 per fanily) is I - $15 \mathrm{j} 1 \mathrm{Fibs}_{\mathrm{g}}$ II $-21.5 \mathrm{jiribs,}$ III - $33.5 \mathrm{jlr} 1 \mathrm{bs}$ and, IV - $61.75 \mathrm{j} 1 \mathrm{ribs}$ classes III \& IV require $34 \%$ and 106\%, respectively, more land per family than the present government allot. ment allows. This is no doubt a cause for much dissatisfaction among the Nad-i-Ali and Marja settlers. The diserepancy between relative production levels and land allotments was pointed out in 1953 and again in 1954 on both of these projects.

A study of the land settlement allocations and charges as related to repayment and operating costs and net farm family income are shown in Table 75. Part A takes the program as HVA has laid it out but using the production-crop value index and estimating farm production costs at $35 \%$ of gross. A much higher livestock purchase is allowed for Class IV land. While the total investment for a Class IV farm $1833 \%$ more than for Class I, the net income is less than one-half. Actually since the Class IV land is nearly all in wheat rather than pasture, the cost of operations should be higher making a wider spread between net income levels. It will be noted in part A that total investment per farm is quite low $\$ 378.75$ to $\$ 507.60$ or $\$ 50$ to $\$ 34$ for Classes I-IV, respectively. The benefit:cost ratio expressed in terms of net annual income total annual costs is high $104: 1$ for Class I to .875:I for Class IV. In all cases the $0 \& M$ costs are figured at 3.50 per acremanmu and debt retirement (1) 4h for 50 years, regardless of debto Shorter loans and higher interest rates would of course increase the annual costs.

Part B takes a more realistic approach. It is assumed here that the entire cost of the Helmand Valley program will be chargeable to the land except for a $25 \%$ allocation to power which had already been deducted in Table 7 the costs from Table 7 . were studied in relation to the percentages of land classes. All projects for which cost estimates are indicated in Table 7 . mates for the Chakansur (Fron the Chakansur Report), the Bakwa (at same rate as Chakansur) and Garmsel. All values were weighted and prowrated to land classes on a percentage basis. High cost projeots such as Nad-i-All and Marja gave high cost values to Class IV lands. From production tables by land classes a mean value of gross production for each class was determined. These comparative cost and production levels are given in Table 76 . To these project construction and land development costs were added the same HVA land allocation and settlement charges as in Part A, except that the basic livestock for Class IV was increased in proportion to the land axea. 


\begin{tabular}{|c|c|c|c|c|c|c|c|c|c|c|c|c|}
\hline \multirow[b]{2}{*}{ GROPS } & \multicolumn{3}{|c|}{ CLASS I } & \multicolumn{3}{|c|}{ CLASS II } & \multicolumn{3}{|c|}{ CLASS III } & \multicolumn{3}{|c|}{ CLASS IV } \\
\hline & $\begin{array}{l}\text { Value } \\
\text { Jirib }\end{array}$ & Jirdbs & $\begin{array}{l}\text { Total } \\
\text { Afs. }\end{array}$ & $\begin{array}{l}\text { Veluo } \\
\text { Jirib }\end{array}$ & Jiribs & $\begin{array}{l}\text { Total } \\
\text { Afs. }\end{array}$ & $\begin{array}{l}\text { Value } \\
\text { Jirib }\end{array}$ & Jiriba & $\begin{array}{l}\text { Total } \\
\text { Afs. }\end{array}$ & $\begin{array}{l}\text { VBIne } \\
\text { Jirib }\end{array}$ & Jir1bs & $\begin{array}{l}\text { Total } \\
\text { Afs. }\end{array}$ \\
\hline $\begin{array}{l}\text { Alfalfa } \\
\text { Corn } \\
\text { Cotton } \\
\text { Garden } \\
\text { Orchard } \\
\text { Wheat } \\
\end{array}$ & $\begin{array}{l}3150 \\
1050 \\
3000 \\
3500 \\
3750 \\
1080\end{array}$ & $\begin{array}{l}2 \\
6 \\
4 \\
0.5 \\
2 \\
0\end{array}$ & $\begin{array}{r}6300 \\
6300 \\
12000 \\
1750 \\
7500 \\
\end{array}$ & $\begin{array}{c}250 \\
900 \\
2250 \\
2500 \\
3125 \\
900\end{array}$ & $\begin{array}{l}4 \\
3 \\
3 \\
0.5 \\
2 \\
7 \\
\end{array}$ & $\begin{array}{l}9000 \\
2700 \\
6750 \\
1250 \\
6250 \\
6400 \\
\end{array}$ & $\begin{array}{r}7800 \\
750 \\
1200 \\
2000 \\
2500 \\
720 \\
\end{array}$ & $\begin{array}{l}5 \\
5 \\
4 \\
0.5 \\
1 \\
9\end{array}$ & $\begin{array}{l}9000 \\
3700 \\
4800 \\
1000 \\
2500 \\
6480\end{array}$ & $\begin{array}{c}1350 \\
375 \\
900 \\
1500 \\
1250 \\
540\end{array}$ & $\begin{array}{c}5 \\
3 \\
0 \\
0.5 \\
1 \\
20\end{array}$ & $\begin{array}{r}6650 \\
1120 \\
- \\
750 \\
1250 \\
10800\end{array}$ \\
\hline $\begin{array}{l}\text { Size \& Gross } \\
\text { Product }\end{array}$ & & 148 & 33850 & & 19.5 & 32350 & & 24.5 & 27480 & & 29.5 & 20570 \\
\hline \multicolumn{13}{|c|}{ * House and other butld1ngs and waste 18} \\
\hline $\begin{array}{l}\text { Average Per } \\
\text { Jirtb }\end{array}$ & $\left.\right|_{2334}$ & - & - & 1659 & - & - & 1122 & - & $\ldots$ & 697 & - & - \\
\hline \$IACre & 09.70 & - & - & 77.97 & - & $=$ & 52.73 & $=$ & $=$ & 32.75 & - & - \\
\hline $\begin{array}{l}\text { Gross Farm } \\
\text { Income } \$ \text { at } \\
42.534=1\end{array}$ & & $\$ 795.47$ & & & $\$ 760.22$ & & & $\$ 645,78$ & & & $\$ 483.39$ & \\
\hline $\begin{array}{l}\text { Per Capits } \\
\text { Net Income } \\
\text { (Prod. Costs }= \\
35 \% \text { gross) }\end{array}$ & & $\$ 92.85$ & & & 86.25 & & & $\$ 69.23$ & & & $\$ 45.10$ & \\
\hline $\begin{array}{l}\text { Jiribs needed } \\
\text { for equal net } \\
\text { per caplta } \\
\text { income }\end{array}$ & & 15 & & & 21.5 & & & 33.5 & & & 61.75 & \\
\hline
\end{tabular}




\section{1}

Tablo: 76

ADJUSTED COSTS OF DEVELOPMENI AND GROSS PRODUCTION VALUES BY LAND CLASSES

\begin{tabular}{|c|c|c|c|c|c|}
\hline Class & $\begin{array}{l}\text { Per } \\
\text { Dollare }\end{array}$ & $\begin{array}{l}\text { Acre Cost } \\
\text { Afghanis }\end{array}$ & $\begin{array}{l}\text { Per Acre Income } \\
\text { Dolliars Afghanis }\end{array}$ & $\begin{array}{l}\text { Per JIresb } \\
\text { Afghanis }\end{array}$ & $\begin{array}{l}\text { Farm Unit } \\
\text { Other Costs } \\
\text { Afghanis }\end{array}$ \\
\hline $\mathrm{I}$ & $\begin{array}{l}265.00 \\
250.00 \\
\end{array}$ & $\begin{array}{l}11,271.15^{\circ} \\
10,633.50 \\
\end{array}$ & 9.570 .15 & 5.785 .07 & 8,600 \\
\hline II & $\begin{array}{l}325.00 \\
295.00 \\
\end{array}$ & $\begin{array}{l}13.823 .55^{*} \\
12.547 .50\end{array}$ & $6.805,60$ & $3.603,70$ & 2,600 \\
\hline III & $\begin{array}{l}3 \% 0.00 \\
330.00 \\
\end{array}$ & $\begin{array}{l}15,737.58 \\
14.036 .20 \\
\end{array}$ & 3.625 .60 & 1.807 .70 & 9,600 \\
\hline
\end{tabular}

\#Upper number assumes Class IV is not used.

In Chapter II, it was pointed out that a family income of 17,840 Afghanis (see Table 11, would allow a fair standard of living. From this, rental and transe. portation were deducted as these ltems would be supplied by other costs already assigned. The study in Part $B_{s}$ resolved itself into determining what farm unit sizes would yilld a net family income of 16,500 Afghanis when all costs were allow cated against the land. Again 0 \& $M$ was calculated at $\$ 3.50$ per acre, production costs at $35 \%$ and debt retirement (all debts) at $4 \frac{3}{2} \%$ over a 50 -year perioc. Ir. ead of the general cropping program as set up by HVA, however, each land class was assumed to produce the most profitable combination of crops adapted to It. Thus Iand classes I \& II were assumed to have 2 high percentage of frults, nuts, cotton, suger beets and similar crops. Class III was adjusted to general fleld erops and Class IV to livestock raising with some mall grains. (Note: it is doubtful Cless IV can yield aatisfactorily with only $1 / 5$ land in legumes as shown in Part $A$ )。

Part B shows that classes I \& II In high value crops may support twice the number of families shown as the generel crop program of Part A. In the long run probably some land will be in each type of crop program. Iand Class III acreage remainod about the sane in Part $B$, as in Part Ao The acroage of Class IV required for a family unit increased to flve times that shown in Part A. The reason is obvious in the allocated construction chacges and land settlement charges. Class IV Iand costing $\$ 425,00$ per acre to develop and requiring a heavy initial investment in legume and gress seeds and 1 ivestock becomes a major enterprise to operate on 2. repayment plan. Even stateside the investment of $\$ 32,500$ for the 75 acre farm. would be considered high. With an investment over 6 tines and land area neaxly 5 times thet shown in Part $\mathrm{A}$ as HVA's goal for Class IV the farm fails to meot all expenses and provide the net income of 16,500 Afghands sought. It is obvious of course that Class IV to be allosated in smell holdings can only yleld a subsistence Income and will not repay the total costs directly allocated on an acreage basis. This does not mean it cannot be ut1lized for where the irrigation system must cross Class IV land the use of the land for Irrigated pasture, hay and amall grains is warranted. It does mean however, that the balance of the project must help carry theburden of developing any Class IV lands and that a project largely of Class IV would hardly be suitable for settlement of people in amall farm units.

The total farm unit investment, when actual or projected costs are considered range from 3 to 6 times that show as the Helmand Valley proposal. 
It is evident that the land cannot bear these charges in its present condity.on. Improved Lrrigation, and production of greater yields of higher value crops mat be sought. Processing and marketing umst be established. In the perlod of farm production development the farm people must be given assistance of all kinds. It is obviously to the future advantage of the government to see that this is done. Otherwise these lands wIII continue at a low level of production and the entire burden of the program must be borne by the governments" is sources of revenue from other parts of the country.

Part C shows for comparison a aimilar analyses of the Columbia River Basin Project in the states. The data are taken from various govemment reports and recordso It is apparent that even charging all Helmand Valley development to the farm units they do not reach the proportions indleated for Columbia Basin farms. The Columbia Basin farmer will have invested $\$ 45,000-\$ 65,000$ in 55 to 120 acre farms. His net income will be $\$ 3,270$ to $\$ 4,144$ or average $\$ 1,200$ per eapita. The Afghan farmer will have Invested about $\$ 2,800$ (omitting Class IV) and his per caplta net earnings will be about $\$ 75,00$. The benef1t:cost ratios are not far different for Classes I-III. The per capita net income is $7.3 \%$ of investment in the Columbia Basin and 13.5\% of investment in the Helmand Basin. These comparisons indicate a favorable future provided the many problems facing the valley devolop. ment are thoughtfully attacked and solved.

\section{Overal1 Helmand Vallev Development Costs and Jroduction Potentials.}

This is a type of summary that w111 be misquoted, misused and misunderstood by many. It is well. to emphasize now that neither costs nor production values can be guaranteed. Every effort has been made, however, to bring together all the in = formation that will bear on the problem. It will suffice here to say that this total picture is a possible long-time goal toward which the Helmand Valley Authority and its cooperating country and foreign associates may plan and strive.

There are many physical pit falls most of which have been mentioned. The most serious, which have not been treated here, are the human problems. The lack of education among the common people, practices, and the general financial, economic and social situation forces the coun try to move ahead slowly and carefuliy. This part of Afghanistan can be made to contribute \& substantial part of the nation's wealth, but only by steady, progressive solution of the physical and human problems that now serve to retard. One very small segment of each project if brought to its ultimate development and wisely utilized could spark an interest among farmers and others and help greatly to speed up the agricultural improvement that must follow construction.

Table 77y summarizes the Helmand Valley projects as surveyed under all contracts to dats. Some of the final maps are not completed so the picture can change for $C$. Arghandab, Bakwa and Marja. Drainage, the most serious problem affecting the future of all projects hes been 1nvestigated in detall only on the two seriously affected desert bench projects, Marja and Nad-i-Ali. Work is progressing in the Darweshan, Shamalan, Tarnak, and Bakwa areas and soon will be initiated in more detail in the Central Arghandab. Without doubt some of these values will change markedly - some for a less favorable, some, we hope, for a more favorable situation.

The benefit:cost ratio as computed compares favorably with that shown for the Columbia Basin Project. Differences in price levels, currency exchange ratios, crop production costs, and developments could easily change the ratios shown and they are submitted only for general study and evaluation purposes. 


\begin{tabular}{|c|c|c|c|c|c|c|c|c|c|c|c|c|c|c|}
\hline \multirow[b]{2}{*}{ Area } & \multirow[b]{2}{*}{$\begin{array}{l}\text { Gross } \\
\text { Acres }\end{array}$} & \multirow{2}{*}{$\begin{array}{l}\text { Net } \\
\text { Irr. 3/ } \\
\text { Acres }\end{array}$} & & & & & \multicolumn{2}{|c|}{ Est. Development Cost } & \multicolumn{4}{|c|}{ Estimated Production } & \multirow{2}{*}{$\begin{array}{l}\text { Total } \\
\text { Annus, } \\
\text { Costs }\end{array}$} & \multirow{2}{*}{$\begin{array}{l}\text { Benefit: } \\
\text { Cost } \\
\text { Rat1o }\end{array}$} \\
\hline & & & $\frac{\text { Net }}{I}$ & $\frac{\operatorname{Acres} \text { in }}{I I}$ & 8ch Land & $\frac{\text { Class }}{I V}$ & $\begin{array}{l}\text { Total } \\
\text { Dollars }\end{array}$ & $\begin{array}{l}\text { Per Acre } \\
\text { Dollars }\end{array}$ & $\begin{array}{l}\text { Value Gross } \\
\text { Total }\end{array}$ & $\begin{array}{l}\text { Products } \\
\text { Per Acre }\end{array}$ & $\begin{array}{l}\text { Net Value } \\
\text { Total }\end{array}$ & $\begin{array}{l}\text { Products } \\
\text { Per Acre }\end{array}$ & & \\
\hline $\begin{array}{l}\text { C. Arghandab } \\
\text { N. Arghandab } \\
\text { Bakwa } \\
\text { Boghra } \\
\text { Chakansur } \\
\text { Darweshan } \\
\text { W. Ka jakaj. } \\
\text { Marja } \\
\text { Seraj } \\
\text { Shamalan } \\
\text { Tarnak } \\
\text { Garmsel } \\
\text { TOTALS }\end{array}$ & $\begin{array}{r}132,220 \\
67,635 \\
350,000 \\
25,000 \\
554,500 \\
73,910 \\
12,780 \\
45,000 \\
106,000 \\
65,000 \\
110,655 \\
123,800 \\
666,500\end{array}$ & $\begin{array}{r}80,475 \\
40,233 \\
115,000 \\
18,180 \\
120,000 \\
45,228 \\
8,068 \\
25,000 \\
62,334 \\
43,818 \\
64,353 \\
41,788 \\
646,409\end{array}$ & $\begin{array}{c}26,048 \\
10,208 \\
17,250 \\
70-\infty \\
7,492 \\
173 \\
3,577 \\
8,184 \\
8,936 \\
\frac{8.00}{81,695}\end{array}$ & $\begin{array}{r}17,110 \\
10,057 \\
34,500 \\
1,531 \\
26,653 \\
16,411 \\
6,790 \\
5,910 \\
10,895 \\
10,127 \\
29,649 \\
6,038 \\
168,881\end{array}$ & $\begin{array}{r}37,317 \\
16,288 \\
46,000 \\
11,649 \\
69,982 \\
21,230 \\
4,30 \\
7,590 \\
29,692 \\
24,064 \\
25,768 \\
31,417 \\
320,997 \\
\end{array}$ & $\begin{array}{r}3,680 \\
27,250 \\
5,000 \\
13,365 \\
95 \\
735 \\
11,500 \\
18,170 \\
1,4,43 \\
-4,333 \\
74,836\end{array}$ & $\begin{array}{r}12,550,000 \\
6,84,8,000 \\
50,000,000 \\
7,000,000 \\
55,000,000 \\
12,500,000 \\
2,500,000 \\
12,000,000 \\
13,215,000 \\
12,000,000 \\
17,400,000 \\
8,360,000 \\
209_{8}, 365,000\end{array}$ & $\begin{array}{l}155.00 \\
170.00 \\
500.00 \\
385.00 \\
500.00 \\
275.00 \\
300.00 \\
480.00 \\
210.00 \\
285.00 \\
270.00 \\
200.00 \\
324.00\end{array}$ & $\begin{array}{r}14,800,000 \\
5,54,0,000 \\
14,000,000 \\
1,470,000 \\
10,84,0,000 \\
5,120,000 \\
1,500,000 \\
2,100,000 \\
4,500,000 \\
4,500,000 \\
11,100,000 \\
2,500,000 \\
77,970,000\end{array}$ & $\begin{array}{r}185.0 \\
137.70 \\
121.70 \\
80.30 \\
98.50 \\
113.20 \\
185.90 \\
84.00 \\
72.20 \\
102.70 \\
172.50 \\
60.00 \\
120.62\end{array}$ & $\begin{array}{r}8,522,800 \\
3,315,000 \\
5,900,000 \\
510,860 \\
3,64,0,000 \\
2,438,000 \\
820,000 \\
635,000 \\
1,950,000 \\
2,080,000 \\
5,960,000 \\
1,003,000 \\
36,774,660 \\
\end{array}$ & $\begin{array}{r}105.00 \\
51.30 \\
27.85 \\
31.60 \\
53.90 \\
101.64 \\
25.40 \\
31.28 \\
47.47 \\
92.60 \\
24.00 \\
56.89\end{array}$ & $\begin{array}{r}6,300,000 \\
2,525,500 \\
8,100,000 \\
959,150 \\
7,200,000 \\
2,682,000 \\
680,000 \\
1,465,000 \\
2,550,000 \\
2,4,20,000 \\
5,140,000 \\
1,497,000 \\
4,, 518,650\end{array}$ & $\begin{array}{l}1.35: 1 \\
1.31: 1 \\
0.73: 1 \\
0.53: 1 \\
0.51: 1 \\
0.91: 1 \\
1.2: 1 \\
0.43: 1 \\
0.76: 1 \\
0.86: 1 \\
1.16: 1 \\
0.67: 1 \\
0.88: 1\end{array}$ \\
\hline
\end{tabular}

If From previous measurements. Latest maps had not been completed and measured at time of completion of this report.

2 Such changes as may be made will be entered later as a revision of this tables 3rd stage of development; benefit:cost ratio is sirnple ratio of annual net income divided by annual expenditureso

$3 /$ Daka from individual area map measurements reduced $8 \%$ for development losses. 
The data shows that a total program cost of over $200_{2} 000,000$ will bring some 646,000 acres into use with an ultimate or potential production value of $78,000,000$ annually and a net-beneflt of $36,000,000$ anmually. At the present $\$ 5,000,000$ in annual benefits from the program are eatimated.

\section{SUMMARY}

The Helmand Valley Surveys have covered over 1,500,000 acres of land wth so13s, drainage, topogrephic and land use surveys. Agronomic, engineexing and economic studies have been made in 2.11 or parts of these areas. This report has brought together the basic cata on climate, solis and agriculture and discusses the relationships of these to the job of land and water resource developnent. Supplemertary reports for oach project summarize the findings as they relate to each project. Maps, soils and drainage logs, labosatory anelyses, description of solls as mapped and other pertinent dats are assembied as appendices to the project supplemental repoxts.

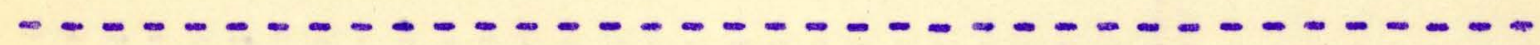

\section{CONCUUSIONS}

The vast watershed of the Chakansur-siestan Basin presents opportunities for development of over $1,000,000$ acres of Irrigated land and $10,000,000$ to $12,000,000$ annual acremfeet of water. The problems vary from simple to complex. Past use has rendered many tracts of land unproductive bacause of salinization, wateralogging, erosion and other factors. Essentially the job is not one of developing a wholo contiguous new block of land but one of reclaiming and rohabilitating a numbor of widely scattered tracts of badly deteriorated land. It 13 a challenge to the nation because of the ultimate value of these water resources and land resources involving a gross area of approximately one-half of Afghanistan.

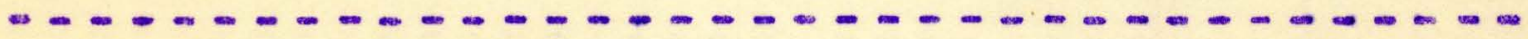

\section{RECOMNENDATIONS}

A strong word of caution is offered here. So many tines work has been started. without adequate information as to its possible outcone ox even basic data on which to plan and design a program. These solls and agronomic studies co afford a much sounder basis for planning than before. Nevertheless, they do not give all the answers. Much more needs to be done on drainage, land reclamation, irrigation, water management, processing plants, roads and maxketso All of these are vital links to using these solis for successful agriculture. Each in turn presents its own series 
of problens and needs careful study.

For the beneflt of the Helmand Valley progran, particularly future work of

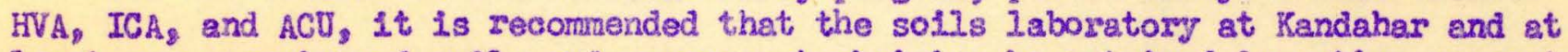
least one experienced solis and agronomy technician be retained in active support of the program. The services rendered W11 be of extreme value, particularly when land reclamation is contemplated. 
APPENDIX I

CLDMATIC TABIES 


\section{CLIBATIC TABLES}

Sumbary of elimatic data for 10 weather gtetions in South Afghantstar.

These tables sumarize from all sources the extating data pertalning to Climate $4 . n$ this section of APghantstan.

The records are incoralote and not continuous for sone stations. No. statement can be mede as to relis.blithy of techriques used or records kept. Sources of dats Include (1) Afghen Moteorologicel Service, (2) International Coopergtion Adninistration (U.S.A.), (3) Boundary Cont ruisston Survey of 1903-1905 and (4) Morrison-Kwodsen Afghanistan, Inc.

An attempt has beor made to organize the data in a convenient form for study and reference: Crop adsptations and growing seasons, weter use requirements of crops have been computed by afd of the inforrmation compiled in these tables. 
Trabia

Latitude $32^{\circ} 50^{\circ}$ in

Station Arghandeb Elev. Naters 1110 Type of
CLIMATOLOGIS AL SUNMART

(\% Sunshins Hours Sama as Kandahar)
$7 / 16 / 57$

\begin{tabular}{|c|c|c|c|c|c|c|c|c|c|c|c|}
\hline \multirow[b]{4}{*}{ Month } & \multicolumn{3}{|c|}{ 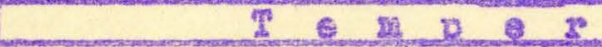 } & 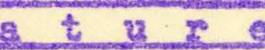 & D 8 & 8 \& & & \multicolumn{2}{|c|}{ Rsin?aI? } & \multirow{2}{*}{\multicolumn{2}{|c|}{ Fyeporat593 }} \\
\hline & \multirow{2}{*}{\multicolumn{2}{|c|}{ Mescinum }} & \multirow{2}{*}{\multicolumn{2}{|c|}{ MLIImun }} & \multirow{3}{*}{$\begin{array}{l}\text { Moan } \\
\text { No. } \\
\text { Tempo. }\end{array}$} & \multirow{3}{*}{$\begin{array}{l}\text { No } \\
\text { Days } \\
32^{\circ} \mathrm{F} \\
\text { or } \\
\text { Lags }\end{array}$} & \multirow{3}{*}{$\begin{array}{l}\text { Mo. } \\
\text { Days } \\
110^{\circ} \\
\text { ox } \\
\text { More }\end{array}$} & \multirow{3}{*}{ Total } & \multirow{3}{*}{$\begin{array}{l}\text { Total } \\
\text { Oves } \\
5 \text { wa } 1 \mathrm{~s} \\
24 \text { hræ. } \\
\text { min }\end{array}$} & & \\
\hline & & & & & & & & & & \multirow{2}{*}{ Tote? } & \multirow{2}{*}{$\begin{array}{l}\text { Daj2y } \\
\text { Renge }\end{array}$} \\
\hline & Maan & Desis Ro. & Mesn & DesIy $B$ & & & & & & & \\
\hline ISRo & 53.6 & 3906307 & $350 \%$ & $24=48.2$ & $460^{3}$ & -2.7 & 0 & 61.7 & 52.2 & 54.3 & $.7=3.5$ \\
\hline$a^{3}{ }^{2}$ & $64 \times 3$ & $50-78.7$ & 32,0 & $30,3-48,5$ & 51.6 & 3.8 & 0 & 472 & 10.0 & 44.8 & $0^{5}=28$ \\
\hline Mesersm & $76 \cos ^{3}$ & $52.3-85.5$ & 47.2 & 35.7 .60 .6 & 61.0 & .6 & Q & 4906 & 60.6 & 7902 & 1.20906 \\
\hline $400^{\circ}-$ & 86.2 & 58.6 .99 .6 & 58.0 & $4206-67.4$ & $72 a 1$ & 0 & 0 & 13.0 & 7.5 & 352.6 & $2.6-12.8$ \\
\hline Mga & 22.6 & 85.8 .907 & 651 & $57,2-76.2$ & 78.8 & 0 & -8 & 5.9 & 0 & 2849 & $4=12.2$ \\
\hline Iงns & 305.2 & 88, em 112,7 & 70.6 & $63.2-57$ & 87.9 & 0 & 500 & 0 & 0 & 218,6 & $5.5-12,2$ \\
\hline $342 x$ & $1060^{2}$ & 97.450311 .66 & 76.2 & $68 \mathrm{an} 2 \mathrm{2}$ & 91.2 & 0 & 202 & 0 & 0 & 218.1 & $502-11.6$ \\
\hline Aves: & 203.0 & $97-110.2$ & 7.s. & $63.6-79.8$ & 87.2 & 0 & 3.0 & 0 & 0 & 27503 & $5.2=11.6$ \\
\hline Sents & 97.5 & $88.2-9.05$ & 62.8 & 56069 & 80.3 & 0 & 0 & 0 & 0 & $263 a^{3}$ & $4-9$ \\
\hline aetse & 8321 & 72.20902 & 4204 & $4304-654$ & 66.2 & 0 & 0 & 0 & 0 & $138 \mathrm{a} k$ & $2,6-7.2$ \\
\hline No\%? & 73.0 & 64.82 .2 & 429 & $35.2=4904$ & 57.5 & 1.0 & 0 & .3 & 0 & 92,4 & $1.4=606$ \\
\hline Des. & 62.3 & $49.6-73.6$ & 37.2 & $28=45.6$ & 49.7 & 6.6 & 0 & 40.0 & 3303 & $60 \mathrm{a}$ & $7.3-3.8$ \\
\hline 10 ta 3 & 20013 & $823,6,312906$ & 64606 & $546.2=773.3$ & 827.5 & 21.7 & 16.0 & 277.5 & $173 \mathrm{oh}$ & 1622.5 & 34.20102 .5 \\
\hline $\begin{array}{l}\text { Aranead } \\
\text { ipea }\end{array}$ & 83.4 & $68.6-9322$ & 53.7 & $4505-64$ & 68.9 & 21.7 & 36.0 & 217.5 & 373.4 & 1621.5 & $2.8-85.6$ \\
\hline
\end{tabular}


Table

acitude $37^{\circ} 40^{\circ} \mathrm{N}_{0}$ Longitude $64^{\circ} 19^{\circ} \mathrm{E}_{0}$

Station Chah-1-An11rg Elov. Meters 790 Type of

Elev. Feet 2591 Rein Gage Standard Refo Ground Level

Evaporation Pan Yoars of

( $(1= \pm=.78)$

\begin{tabular}{|c|c|c|c|c|c|c|c|c|c|c|c|c|}
\hline \multirow{4}{*}{ Month } & \multirow{3}{*}{\multicolumn{2}{|c|}{ I $\mathrm{m} n \mathrm{e}$}} & \multicolumn{2}{|c|}{$e_{a t u} a^{2} e$} & \multicolumn{3}{|c|}{$D=z^{2}$} & \multicolumn{2}{|c|}{ Rainfal1 } & \multirow[b]{2}{*}{ Eveporation } & \multirow{4}{*}{$\begin{array}{l}\text { Rel. } \\
\text { Huss. } \\
\text { Meen } \\
\text { No. }\end{array}$} & \multirow{4}{*}{$\begin{array}{l}\text { Wind } \\
\text { Veloc- } \\
\text { 1.ty } \\
\text { M1les } \\
\text { Pex } \\
\text { Hour }\end{array}$} \\
\hline & & & & & \multirow{3}{*}{$\begin{array}{l}\text { Mean } \\
\text { Mo. } \\
\text { Temp. }\end{array}$} & \multirow{3}{*}{$\begin{array}{l}\text { No. } \\
\text { Days } \\
32^{\circ} \mathrm{F} \\
\text { ox } \\
\text { Less }\end{array}$} & \multirow{3}{*}{$\begin{array}{l}110 . \\
\text { Dayg } \\
210^{\circ} \\
\text { or } \\
\text { Mors }\end{array}$} & \multirow{3}{*}{ Total } & \multirow{3}{*}{$\begin{array}{l}\text { Totel } \\
\text { Ovex } \\
5 \text { man in } \\
24 \text { hre. } \\
\text { man }\end{array}$} & & & \\
\hline & & & & nimum & & & & & & \multirow{2}{*}{\begin{tabular}{c|c} 
Daily \\
Tats 1
\end{tabular}} & & \\
\hline & Mean & Daily $\mathrm{Bo}$ & Mesn & Das 1 Y $R$ & & & & & & & & \\
\hline Jano & 57.7 & $48.5-70$ & 3400 & $20 \operatorname{mos}: 6.6$ & 45.8 & 11 & 0 & 3206 & 25.0 & $4 7 . 6 \longdiv { 1 - 1 2 0 6 }$ & 71.0 & 5.3 \\
\hline Eab. & 6607 & $51.7-72.3$ & 39.5 & $28,5=57,3$ & 523 & 5.5 & 0 & 31.7 & 22.0 & $64.6 \mid-5=3$ & 457 & 5.3 \\
\hline Yar. & 74.2 & $47.7-73,3$ & 67,6 & $26.6-46.2$ & 60.9 & 1.5 & o & 38.9 & 36.0 & 104.12 .6 .95 .7 & 540 & 6.5 \\
\hline $\mathrm{Aps}_{9}$ & 89.8 & 73.20103 .1 & 60.2 & $50.4-75.7$ & 75.0 & 0 & 0 & $50 \%$ & 4.6 & $292 \cdot 3153=10$ & 37.5 & 7.8 \\
\hline June & 106.7 & 912511405 & 72.3 & $58.6-82.0$ & 892 & S & 6 & 392 & 0 & 32029017 & 302 & 6.9 \\
\hline 5uly & 208.7 & $10405=113.0$ & 75.7 & $66.1-86.8$ & 92.2 & 0 & 8 & 5.0 & 0 & $317.9130-42$ & 32.0 & 43 \\
\hline Aug & 102.5 & $94,9=109$ & 6884 & $60.3 \times 74.3$ & 85.6 & 0 & 1 & 0 & 0 & $281.3 \mid 23.7-424$ & 3033 & 27 \\
\hline Jepto & 97.7 & $89.3=203.8$ & 58.7 & $49.5=652$ & 77,9 & 0 & 0 & 0 & 0 & $207.420 .6-31,2$ & 32.0 & 3.7 \\
\hline Sete & 8409 & 75.809208 & 47.9 & $38,6056,4$ & 66.4 & 0 & 0 & 12 & 0 & $1 2 2 . 6 \longdiv { 3 . 3 - 1 0 , 6 }$ & 43.0 & 322 \\
\hline Tovo & 728 & $65=87.8$ & 37.6 & $35.8-56,3$ & 552 & 2 & 0 & 1 & 0 & $87.92=8.6$ & 45.7 & 2.8 \\
\hline 200 & 62,3 & $5 / .9=73.8$ & 35.3 & $22-47$ & 48.8 & 12 & 0 & 24,2 & 1200 & 57.013 .60403 & 59.5 & 3.8 \\
\hline rotal & 1021.6 & $890.7-1130.0$ & $6440^{2}$ & $54606-76900$ & 832.8 & $32 \cdot 4$ & 17 & 335.5 & 82.6 & 207402183.3221 .7 & 53324 & 52.5 \\
\hline $\begin{array}{l}\text { Annual } \\
\text { Yean }\end{array}$ & 85.3 & $74.2 \mathrm{es} 9 \mathrm{k} \cdot 1$ & 53.6 & $42.8-64.0$ & 6904 & 32 & 27 & 135.5 & 89.6 & $2074.26 .9-24=3$ & 64,49 & 5,0 \\
\hline
\end{tabular}

* Average of incomplete records from Chah- $=$ Anjirs, Marje \& Lashkerga. 
5.2. 3

Jatitude $32^{\circ}$ in Ne Lonos tude $62^{\circ} \mathrm{Co} \mathrm{x}$

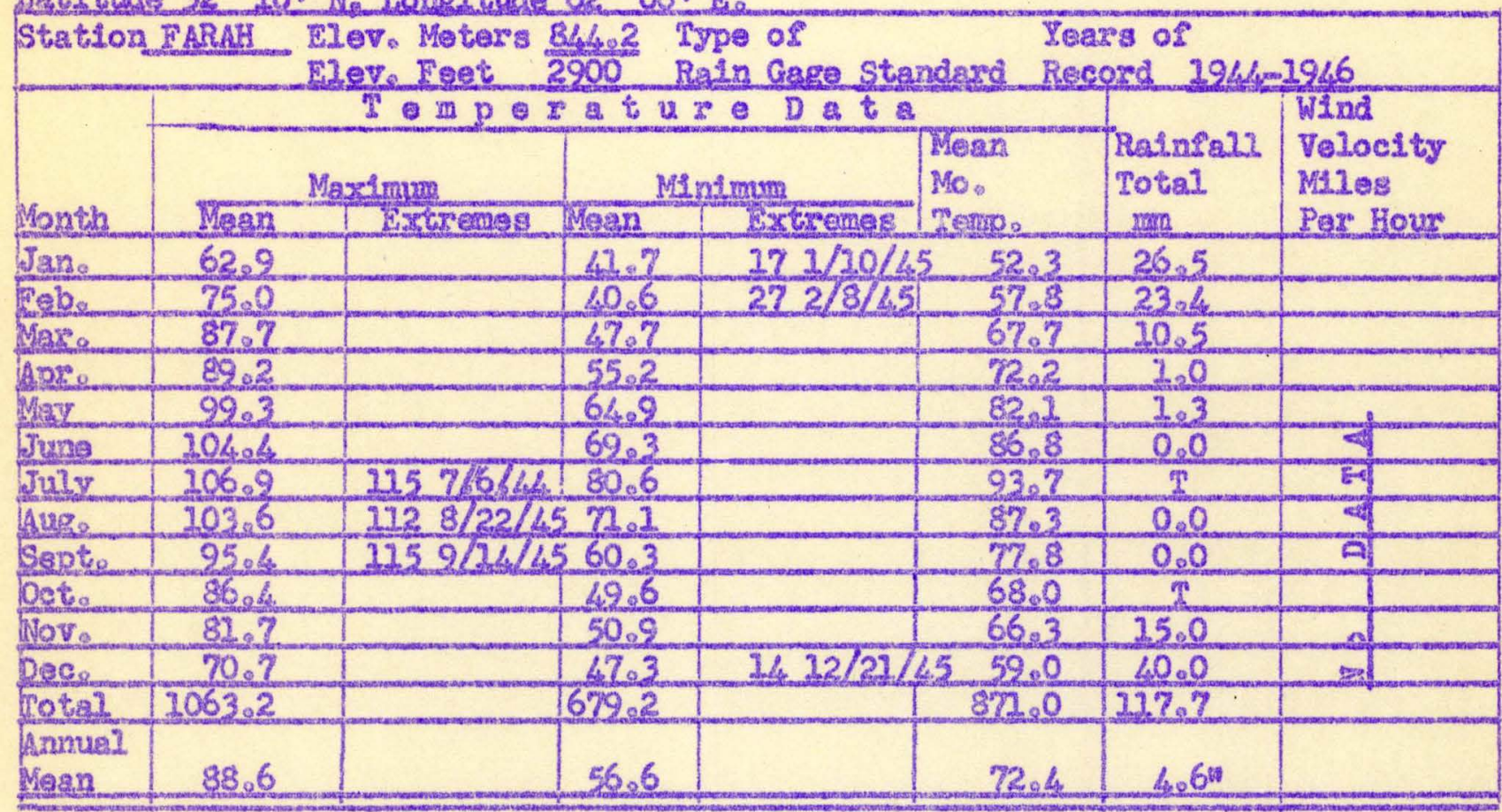


Tabie

4

CLOMATCLOCKCAL SUMART

$7 / 26 / 57$

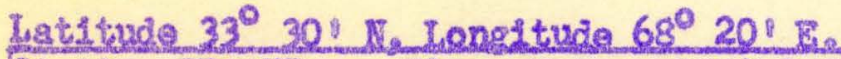

\begin{tabular}{|c|c|c|c|c|c|c|}
\hline \multicolumn{2}{|c|}{ Station GLAZNI } & \multicolumn{4}{|c|}{ lev. Meters 2240.9 Iype of $\quad$ Tears of } & $3944=1947$ \\
\hline & \multicolumn{3}{|c|}{ Temporature Datg. } & \multirow{2}{*}{$\begin{array}{l}\text { Rainfel1 } \\
\text { Total } \\
\text { nen }\end{array}$} & \multirow{2}{*}{$\begin{array}{l}\text { Relativo } \\
\text { Hunidity } \\
\text { Mean } \\
\text { Month? }\end{array}$} & \multirow{2}{*}{$\begin{array}{l}\text { Wlad } \\
\text { Velocit ty } \\
\text { Miles } \\
\text { Por How }\end{array}$} \\
\hline Month & $\begin{array}{l}\text { Nexdimuan } \\
\text { Neen }\end{array}$ & $\begin{array}{l}\text { Minimuman } \\
\text { Monn }\end{array}$ & $\begin{array}{l}\text { Mears } \\
\text { Mo }\end{array}$ & & & \\
\hline $\operatorname{Jan}_{2}$ & 32.2 & 20.4 & 23.6 & 43.5 & 70.3 & 387 \\
\hline $\mathrm{Ceb}_{0}$ & 33.6 & 17.7 & 22.6 & 40.7 & 746 & 6.27 \\
\hline Max: & 39.6 & 28.2 & 33.9 & 5207 & 6503 & 5.60 \\
\hline Aps: & 52.9 & 38.7 & 45.8 & 27.7 & 47.6 & 8.29 \\
\hline May & 72.7 & 43.5 & 58.1 & 27.0 & 470 & 7.39 \\
\hline Jugo & 84.0 & 45.3 & 64.6 & 9.2 & 33.0 & 6.05 \\
\hline โบบ? & 88,5 & 56.3 & 7204 & $110 ?$ & 4500 & 6.50 \\
\hline Aug $\Omega$ & 20321 & 5204 & 72.2 & 3.0 & 49.3 & 6.27 \\
\hline Septo & 81.9 & 450 & 6324 & Zulk & 67,0 & 5.60 \\
\hline Det & 69.3 & 34.5 & 52.2 & 0.0 & 37.6 & 737 \\
\hline Novo & 52.4 & 37.1 & $42 . ?$ & 2.1 & 49.0 & 5.82 \\
\hline Des. & 46.6 & 37.8 & 42.2 & 22.5 & 66.6 & 732 \\
\hline Totel & 756,5 & 437.9 & 3972 & 2240 & 62603 & 75.94 \\
\hline Annual & 63.0 & 36.49 & 49.7 & 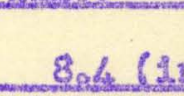 & 52.2 & 6,33 \\
\hline
\end{tabular}

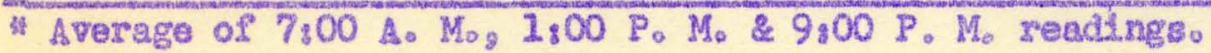


Latd tude $34^{\circ} 200 \mathrm{~N}$. Longitude $62^{\circ}$ I0

\begin{tabular}{|c|c|c|c|c|c|c|c|}
\hline \multicolumn{2}{|c|}{ Station MEPAT } & $\begin{array}{l}\text { Qlev. Moters } \\
\text { Slev. Feet }\end{array}$ & \multicolumn{3}{|c|}{$\begin{array}{l}222.6 \text { Type of } \\
3026 \text { Rain Gage Standerd }\end{array}$} & \multicolumn{2}{|c|}{8200 of $294-1248$} \\
\hline \multirow[b]{3}{*}{ Nonth } & \multicolumn{5}{|c|}{ Tangerature Dats } & \multirow{3}{*}{$\begin{array}{l}\text { Reinfaม } \\
\text { Total } \\
\text { max }\end{array}$} & \multirow{3}{*}{$\begin{array}{l}\text { Whind } \\
\text { Velocity } \\
\text { MLIes } \\
\text { Per Hour }\end{array}$} \\
\hline & \multicolumn{2}{|c|}{ Maximyy } & \multirow{2}{*}{\multicolumn{2}{|c|}{ MinImum }} & \multirow{2}{*}{$\begin{array}{l}\text { Masar } \\
\text { Mo. } \\
\text { Cerio. }\end{array}$} & & \\
\hline & Masn & Extromes & & & & & \\
\hline Jag, & 50.0 & & 30.9 & $0.501 / 19 / 43$ & 40.4 & 62.0 & 9.6 \\
\hline Esbo & $54 \cdot 3$ & & 33.8 & $23^{\circ} 2 / 3 / 43$ & $460^{5}$ & 33.3 & 8.7 \\
\hline Mar: & 64.0 & & 40.8 & $23^{\circ} 3 / 9 / 48$ & 5200 & 38.7 & 87 \\
\hline Aps: & 77.7 & & 47.7 & $26^{\circ} \quad 47 / 45$ & 62.7 & 8.7 & 8.5 \\
\hline $\mathrm{Nov}$ & 87.3 & $103^{6} 5 / 2 / 46$ & 56.7 & & 7.7 & $43^{3}$ & 89 \\
\hline Juns & 93.6 & $104^{\circ} 6 / 26 / 45$ & 6404 & & 79.0 & 0.0 & 23.6 \\
\hline Fuly & 97.3 & $210^{\circ} 7 / 8 / 46$ & 723 & & 84.8 & $\pi$ & $14 x 8$ \\
\hline Ang. & 94.5 & $208^{\circ} 8 / 1 / 42$ & 70,5 & & 82.5 & 0.0 & 27,7 \\
\hline Septo & 90.1 & $103^{6} 9 / 5 / 48$ & 56.3 & & 7382 & 0.0 & 17.6 \\
\hline Det. & 82.1 & & 4404 & $28010 / 27 / 45$ & 62.9 & I & 6.5 \\
\hline Hor & 6629 & & 35.4 & & 52.9 & 78 & 6.3 \\
\hline beco & 51.1 & & 32.2 . & $70 \quad 12 / 21 / 48$ & 42.6 & 33.7 & 6.0 \\
\hline Tota? & 907.9 & & 584.8 & & 746.6 & 288.6 & 237.5 \\
\hline Annus: & & & & & & & \\
\hline Mean & 75.65 & & 48.73 & & 6200 & $2043^{n}$ & 2.8 \\
\hline
\end{tabular}


Table

Latitude $34^{\circ}$ 20 Nil Longitude $69^{\circ} 10^{\circ} \mathrm{E}$

\begin{tabular}{|c|c|c|c|c|c|}
\hline station & abou & $\begin{array}{l}\text { Moters } \\
\text { Foet }\end{array}$ & $\begin{array}{l}\text { Type of } \\
\text { Rain Gege }\end{array}$ & ndard & \\
\hline & & ture Dat & & & Wind \\
\hline & $\%$ & Mees & Rainfall & Evapo & Velocity \\
\hline & Sunehdino & Mo. & Tota? & Total & MLIos \\
\hline Month & Hours & Tamo. & man & son & Por Hour \\
\hline $\mathrm{Jan}_{0}$ & 7.06 & 32.00 & 30.7 & 48 & 2.69 \\
\hline $\mathrm{Fab}_{8}$ & 6.90 & 32.28 & 36.3 & 69 & 3.36 \\
\hline Sax: & 8,36 & 43.52 & 1029 & 116 & 3.53 \\
\hline $\mathrm{Apr}_{\mathrm{S}}$ & 8.81 & 53.96 & 93.2 & 169 & 3.02 \\
\hline $\operatorname{Vay}$ & 9.75 & 65.30 & 19.8 & 230 & 309 \\
\hline June & 9.74 & 73.76 & 5.3 & 328 & 3.81 \\
\hline In]y & 2.92 & 78.26 & 3.3 & 396 & 4.59 \\
\hline A4s: & 9.35 & 74.84. & 3.5 & 300 & 3.07 \\
\hline Sopt. & 8.36 & 66.92 & 0.3 & 304 & 3.29 \\
\hline oct. & 7.89 & 55.22 & $42^{2}$ & 273 & 2025 \\
\hline tov, & 6.99 & 44,96 & 20.8 & 217 & 1.70 \\
\hline & 6.88 & 34.70 & 20.9 & 55 & $38 \%$ \\
\hline Total & 200.00 & 654.72 & 344.2 & 2305 & $36_{2} 13$ \\
\hline Arnual & & & & & \\
\hline yean & & $53.56^{\circ}$ & 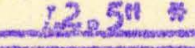 & 90.752 & 32. \\
\hline
\end{tabular}

- A 30-Iser Average (ICA report shows $13.4^{\circ}$ Avarage). 
Ista tude $32^{\circ} 20^{\circ} N_{0}$

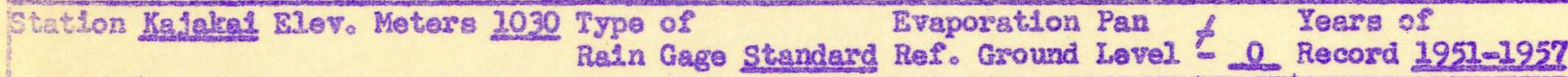

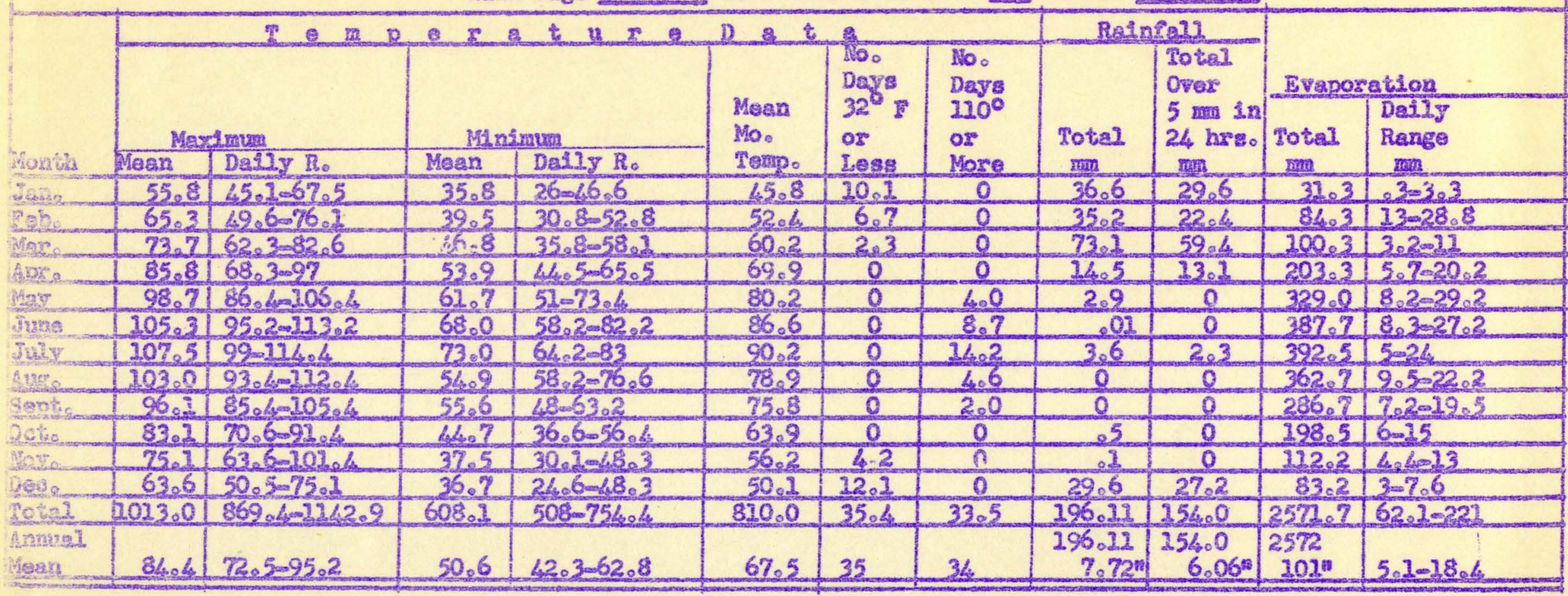


Tabla

Latitude $30^{\circ} 32^{\prime}$ as $31^{\circ}$ 40 18

Longitude $60^{\circ} 55^{\circ}-62^{\circ} 20^{\circ} \mathrm{E}$

Station Kall-Kans niev, Maters

Chakansur EIVV. Feet

190 Type of

Evaporation Para

Tears of 1903-1905

-

1607 Rain Gage Standard Res. Ground Level o gpan Pan

Record: 1952-1953

(at ground level)

$1955=1956$

\begin{tabular}{|c|c|c|c|c|c|c|c|c|c|c|}
\hline & T & in $D$ 당 & है & $x \quad 0$ & D \& $\&$ & $2 x$ & & & & Parts,a? \\
\hline Moath & $\begin{array}{l}\text { Mestinum } \\
\text { Mesn }\end{array}$ & $\begin{array}{l}\text { Mİn:mun } \\
\text { Mำan }\end{array}$ & $\begin{array}{l}\text { of } \\
\text { Sunshine } \\
\text { Howหrg }\end{array}$ & $\begin{array}{l}\text { Mosa } \\
\text { Mo } \\
\text { Temp }\end{array}$ & $\begin{array}{l}\text { No. days } \\
32^{\circ} \text { \& } \text { \% } \\
\text { Lens }\end{array}$ & $\begin{array}{l}\text { Mo days } \\
110^{\circ} \text { or } \\
\text { Mose }\end{array}$ & $\begin{array}{l}\text { RaInial } \\
\text { Total } \\
\text { min }\end{array}$ & $\begin{array}{l}\text { Evapo } \\
\text { Totea1 } \\
\text { ing }\end{array}$ & $\begin{array}{l}\text { Rolativ } \\
\text { Bumid1 ty } \\
\text { Mean } \\
\text { Monthly }\end{array}$ & $\begin{array}{l}\text { Whad } \\
\text { Velocjty } \\
\text { M1.6\% } \\
\text { Per Hous }\end{array}$ \\
\hline sans & 55.2 & 32.5 & 7.250 & 43.7 & 25 & & 25.10 & 66.29 & 53 & 6.5 \\
\hline $\mathrm{Fob}_{\mathrm{m}}$ & 66.3 & 35.6 & 7.000 & 50.9 & 8 & & 20,30 & 90.42 & 45 & 8,0 \\
\hline Mar. & 73.9 & 64.8 & 8.375 & 58,3 & 3 & & 15.25 & 115.32 & 52 & 8.5 \\
\hline $\operatorname{sos}=$ & 88.8 & 55.5 & 8.735 & 72.3 & & 5 & 5.10 & 176,02 & 65 & 725 \\
\hline Noy & 103.2 & 65.1 & 9.580 & 83.2 & & 32 & 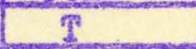 & 287.02 & 37 & 8.5 \\
\hline Jinge & 207.2 & 7004 & 9.545 & 88.8 & & 28 & 0.0 & 483.87 & 27 & 12.0 \\
\hline 3127 & 107.3 & 76.9 & 9.720 & 9300 & & 22 & 9 & $520 . \%$ & 30 & 15,0 \\
\hline Aves. & 102,6 & 72.5 & 9250 & 87,6 & & 78 & 0.0 & $4710^{48}$ & 22 & 150 \\
\hline Septs. & 94.5 & 61.1 & 8,310 & 77.8 & & & 0.0 & 320,80 & 32 & 10,0 \\
\hline Sets & 87.2 & 46.1 & 7.960 & 66.7 & 3 & & 0.0 & 226.66 & 43 & 6.5 \\
\hline Hor & 78.6 & $32.2^{3}$ & 7.250 & 58.2 & 3 & & 9 & $132 . \%$ & 50 & 2.5 \\
\hline Decs & 65.5 & 33.5 & 7.095 & 429 & 32 & & 6.35 & 95.25 & 54 & 405 \\
\hline Nots: & 10270 & 6323 & 100.000 & 830.9 & 13 & 75 & 72.10 & 2923054 & 695 & 106.5 \\
\hline $\begin{array}{l}\text { Anmenal } \\
\text { Horan }\end{array}$ & 85.58 & 52.57 & nomeses & 62.2 & 12 & 75 & $\begin{array}{l}72.40 \\
2.85\end{array}$ & $\begin{array}{r}2923.54 \\
115.10\end{array}$ & 475 & 8.9 \\
\hline
\end{tabular}

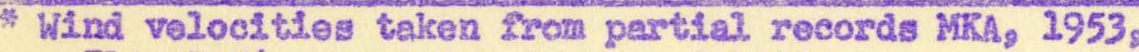
If $\mathrm{A}_{8}$ 1956, \& British Survey of 1904。 
Table

Latitude $31^{\circ} 34^{\circ} 12^{n} N$ Longltuds $64^{\circ} 21^{\circ} 22^{\text {t1 }} \mathrm{E}$

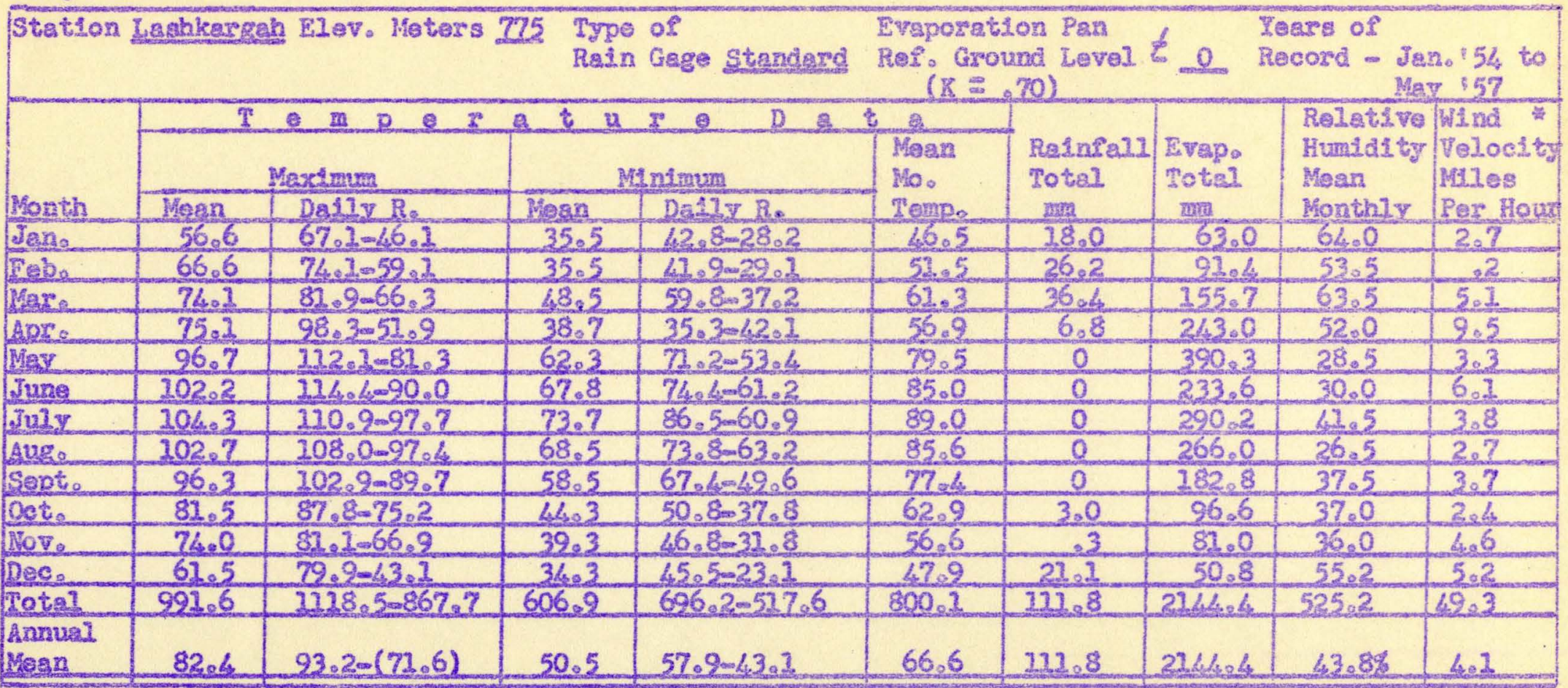

"Average of Incomplete records from Lashkargah, Maxja \& Chah-1-Anj/zrso 


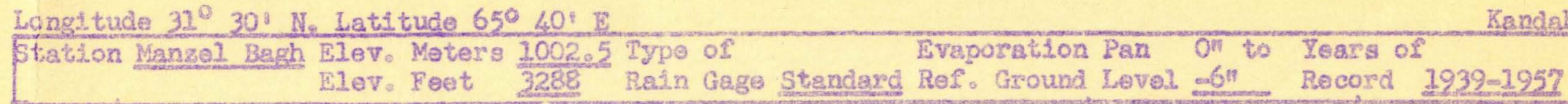

\begin{tabular}{|c|c|c|c|c|c|c|c|c|c|c|c|c|c|c|c|c|c|}
\hline \multirow[b]{2}{*}{ Month } & \multicolumn{8}{|c|}{ 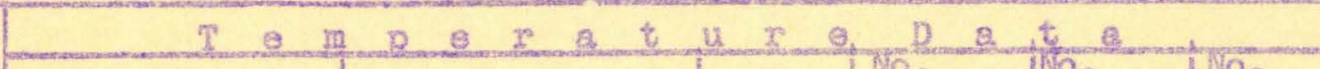 } & \multicolumn{2}{|c|}{ Rainfo]1 } & \multirow{2}{*}{\multicolumn{2}{|c|}{$\begin{array}{l}\text { Surface pen } \\
\text { free water } \\
\text { Bvaporation } \\
\text { 1.aly }\end{array}$}} & \multirow{2}{*}{$\begin{array}{l}\text { Pes: } \\
\text { Re? } \\
\text { Hurn: } \\
794 P\end{array}$} & \multirow{2}{*}{$p=1950$} & \multirow{2}{*}{$\begin{array}{l}\text { Means } \\
\text { Dally } \\
\text { Range }\end{array}$} & \multirow{2}{*}{$\begin{array}{l}\text { Hind } \\
\text { Yoloes } \\
\text { (est) } \\
\text { Milas } \\
\text { Por } \\
\text { Hour }\end{array}$} & \multirow{2}{*}{$\begin{array}{l} \\
\% \\
\text { Total } \\
\text { Sunshine } \\
\text { Houx's }\end{array}$} \\
\hline & \multicolumn{2}{|c|}{$\begin{array}{c}\text { Furtrene a } 112^{\circ} \\
\text { Mexinum }\end{array}$} & \multicolumn{2}{|c|}{$\begin{array}{c}\text { Extreme }=12^{\circ} \\
\text { Minimum }\end{array}$} & $\begin{array}{l}\text { Mean } \\
\text { Mo. } \\
\text { Tomp. }\end{array}$ & $\begin{array}{l}\text { Ho. } \\
\text { nights } \\
32^{\text {F }} \\
\text { or } \\
\text { Less }\end{array}$ & $\begin{array}{l}\text { Wo. } \\
\text { whtghts } \\
20^{5} \mathrm{~F} \\
\text { or } \\
\text { Less }\end{array}$ & $\begin{array}{l}\text { Woo } \\
\text { deys } \\
120^{\circ} \\
\text { ar } \\
\text { More }\end{array}$ & $\mid \begin{array}{c}\text { Total } \\
\text { mas }\end{array}$ & {$\left[\begin{array}{l}\text { otal } \\
\text { over } \\
5 \text { mon } 2 x \\
24 \text { mos } \\
\text { mon }\end{array}\right.$} & & & & & & & \\
\hline danc & 55.4 & $44-67$ & 32.3 & 220048 & 4400 & 17.3 & 2 & 0 & 66.60 & 52.5 & 43.9 & $1.3=2$ & 62 & 0 & $126-70$ & 400 & 7.220 \\
\hline rebo & 6204 & $45-74$ & 40,3 & $25-55$ & 48.7 & 980 & 2 & 0 & 46.20 & 31.8 & 653 & $11=3$ & 52 & 8 & $127-67$ & 42 & 6.990 \\
\hline Maro & 72,6 & $53-83$ & -46.5 & $33-61$ & 57.3 & 102 & 0 & 0 & 35,60 & 32.1 & 98.3 & $12=5$ & 18. & 5 & $121-58$ & 45 & 8.370 \\
\hline Apr: & 83.6 & $63=95$ & 53.9 & $39-66$ & 6701 & 0 & 0 & 0 & 17.80 & 7.9 & 1652 & $12-9$ & 43 & 2 & $178-63$ & 500 & 8.740 \\
\hline May. & $24: 5$ & $86-103$ & 61.4 & $149-72$ & 75,2 & 0 & 0 & 0 & 5.67 & 1,0 & 228.8 & $16-7$ & $3^{n}$ & 10. & 17063 & 4.0 & 9.600 \\
\hline Juns & 12012 & $88-109$ & 66.05 & 155.64 & 813 & 0 & 0 & 4 & 0.15 & 0 & 256.0 & $8=20$ & 33 & 4 & $22-48$ & 45 & 2.570 \\
\hline Iuนz & 1206.3 & $95-107$ & 63.0 & $61-75$ & 84.7 & 0 & 0 & 3 & 3.501 & 203 & 273.1 & $5-2$ & 29 & 9 & $24=50$ & 5.5 & 2.745 \\
\hline Aug & 100.3 & 93.105 & $64 \times 5$ & $560^{7} \%$ & 81.6 & 0 & 0 & 2 & 0,061 & 0 & 260.3 & $7=13$ & 26 & 2 & $12=48$ & 35 & 9.270 \\
\hline Sopt: & 220 & $94-105$ & 52.5 & $43-67$ & 72.9 & 0 & 0 & 0 & 0.00 & 0 & 291.5 & $5-11$ & 26 & 3 & $122-48$ & 2.5 & 8,340 \\
\hline Oet. & 792 & $65-92$ & 420 & $34-51$ & 63,6 & 2 & 0 & 0 & 0.15 & 0 & 132.8 & $12-6$ & 33. & 9 & $12=56$ & 20 & 7.950 \\
\hline $\mathrm{Nov}_{\mathrm{S}}$ & 6901 & $57-82$ & 3401 & $26-45$ & 53.5 & 8.4 & c & 0 & 1.311 & -4 & 72.5 & $11-5$ & 46 & 3. & $22=67$ & 30 & 7.330 \\
\hline Qec: & 61.7 & $\frac{48-73}{2}$ & 30.8 & $23=47$ & $\frac{4506}{6}$ & 252 & 3 & 0 & 19.20 & 1105 & -48.3 & $11-2$ & 54 & 2 & $122-76$ & 12.5 & 7,080 \\
\hline Total & 275,3 & $822=1093$ & 587.3 & $664=730$ & 726.0 & $=-\infty$ & $=$ & $=$ & mesos $\quad 1$ & $I=$ & $=$ & $132,3=52$ & $42^{5}$ & 3 & $273=70$ & $2432^{2}$ & 200,00 \\
\hline $\begin{array}{l}\text { Annual. } \\
\text { desa }\end{array}$ & 81.2 & $69-91$ & 68.9 & $39-61$ & 64.6 & 53. & 7 & 8 & 188,4 & 237.5 & 2843.5 & $3=7$ & 47 & 3 & $20-60$ & {$\left[\begin{array}{c}3.7 \\
\text { moh }\end{array}\right.$} & 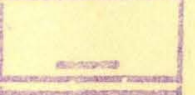 \\
\hline
\end{tabular}

* IT full 24 hour days have been below $32^{\circ} F_{0}$ 


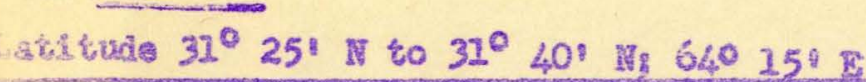

Station Marjs EIov. Haters 765 Typo of

Eler. Feot 2510 Rain Gage standard Ref. Ground Level of $2^{\text {re }}$

Tears

of Record - Jan. 1954 to Max. 1257

\begin{tabular}{|c|c|c|c|c|c|c|c|c|c|c|c|c|}
\hline \multirow[b]{5}{*}{ lontes } & \multirow{4}{*}{\multicolumn{2}{|c|}{ Masinum }} & \multirow{4}{*}{\multicolumn{2}{|c|}{$\frac{x^{2}-v^{2} x}{\text { Mndmum }}$}} & \multirow{2}{*}{\multicolumn{3}{|c|}{$D$ a $t a$}} & \multicolumn{2}{|c|}{ Rainies? } & \multirow{3}{*}{\multicolumn{2}{|c|}{ EFaporation }} & \multirow{5}{*}{$\begin{array}{l}\text { W1nd } \\
\text { Valo } \\
\text { Miles } \\
\text { Pax }\end{array}$} \\
\hline & & & & & & & & \multirow{4}{*}{ Total } & \multirow{4}{*}{$\begin{array}{l}\text { Total } \\
\text { Over } \\
5 \text { man } 1 \mathrm{n} \\
24 \mathrm{hrs} \\
\text { ran }\end{array}$} & & & \\
\hline & & & & & \multirow{3}{*}{$\begin{array}{l}\text { Mean } \\
\text { Moo } \\
\text { Tomp. }\end{array}$} & \multirow{3}{*}{$\begin{array}{l}\text { No. } \\
\text { Days } \\
30^{\circ} \mathrm{F} \\
\text { or Lese }\end{array}$} & \multirow{3}{*}{$\begin{array}{l}\text { No. } \\
\text { Days } \\
110^{\circ} \\
\text { Or More }\end{array}$} & & & & & \\
\hline & & & & & & & & & & \multirow{2}{*}{ Total } & \multirow{2}{*}{$\begin{array}{l}\text { Daily } \\
\text { Pange } \\
\text { min }\end{array}$} & \\
\hline & Iosn & Defly R & Meale & Dej17 Ro & & & & & & & & \\
\hline 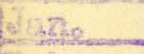 & 59.3 & $52-71$ & 34,6 & $27.5-8 ?$ & 66.7 & 20.5 & 0 & 41.4 & 32.2 & 659 & $1.6-7$ & 49 \\
\hline $3 b_{0}$ & 66.7 & $54.5-79,5$ & 39.9 & 27.60051 .6 & 53.3 & 4 & 0 & 20.3 & 403 & 119.0 & $1=2.6$ & 503 \\
\hline x. & 73.8 & $59.5-83$ & 57.3 & $20-60$ & 625 & 0 & 0 & 40.3 & 35.2 & 172.0 & 1012 & 5.7 \\
\hline 20 & 86.5 & $67-97$ & 59.5 & W. $5-68.5$ & 73.0 & 0 & 0 & 4.8 & $\infty$ & 2032 & $3.5-15.5$ & 8.5 \\
\hline 8 & 100.0 & $88-10905$ & 67.7 & 60.77 .5 & 83.8 & 0 & 6.5 & 0 & 0 & 381.4 & $6.5=27.5$ & 5.8 \\
\hline whe & 103.5 & $96-111.5$ & 72.0 & $63.3=82$ & 87.7 & 0 & b. & 0 & 0 & 397.8 & 10.5019 & 6.5 \\
\hline 137 & 1065 & $95.5-112.5$ & 52.5 & $72-85$ & 93.0 & 0 & 8 & 0 & 0 & 163.0 & $10,5=18.5$ & 400 \\
\hline$\theta_{0}$ & 103.0 & 93112 & 72.5 & 670083 & 87.2 & 0 & 1 & $\infty$ & 0 & 437.8 & $10.5=20$ & 3.8 \\
\hline $8 t_{0}$ & 97.9 & $87-103$ & 63.3 & $58-72$ & 80.6 & 0 & 0 & 0 & a & 278.3 & $8.5=16.5$ & 3.7 \\
\hline esto. & 83.5 & $72-95$ & 49.2 & 45.66 & 66.3 & 0 & 0 & 0 & 0 & 203.5 & $5-14.5$ & 33 \\
\hline Wor. & 74.5 & $64-52.5$ & 42.5 & $36.5-50.5$ & 58.5 & O. & 0 & 0 & 0 & 166.0 & $4=9$ & 3.6 \\
\hline 000 & $61 \times 3$ & $47-72$ & 37.3 & 2868 & 49,3 & 6 & 0 & 27.7 & 0 & 94.8 & 105.5 & 403 \\
\hline 642 & 2019.3 & 875.5011727 .5 & $668.3^{3}$ & 569.60 .792 .3 & 841.9 & 20.5 & 12.5 & 124.3 & 72.7 & 2932.5 & $63.6-168.6$ & 5924 \\
\hline $\begin{array}{l}\text { A mus i } \\
\text { meas }\end{array}$ & 869 & $72.9-93.9$ & 55.6 & $4784-65.2$ & 70.2 & 21 & 20 & 124.3 & 72.7 & 2983 & $5,3-14$ & 5.0 \\
\hline
\end{tabular}

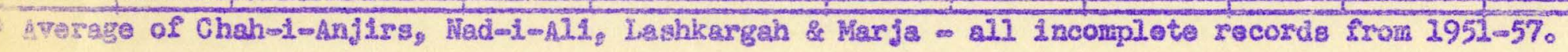


APPENDIX II

ANALYSES OF GROUND UATER 
CEMRAL ARGHANDAB AETA

MORYH ARGHAHDAB AREA

\begin{tabular}{|c|c|c|c|c|c|c|c|c|}
\hline Location & $\begin{array}{l}\text { Randahar } \\
\text { Arc. Wal1 } \\
\text { Aporox, } 185\end{array}$ & $\begin{array}{l}\text { Diversion } \\
\text { Dam } \\
\text { Uel3 }\end{array}$ & Manzel & Bagh wells & $\begin{array}{l}\text { Artestan } \\
215 \text {. Pt. }\end{array}$ & 248 & $\begin{array}{l}\text { Well Moso } \\
35\end{array}$ & 106 \\
\hline \multicolumn{9}{|l|}{ Conductivity: } \\
\hline ECxi0 $25^{\circ} \mathrm{C}$ & 2046 & 800 & 903 & 14,00 & 2499 & 301 & 647 & 1267 \\
\hline$\%$ Na & 63 & 41 & 43 & 29 & 54 & 33 & 26 & 34 \\
\hline ofl & 7.8 & 7.6 & 7.4 & 7.3 & 7.4 & 704 & 7.6 & 7.3 \\
\hline \multicolumn{9}{|l|}{ Dissolved sol.2ds: } \\
\hline ppens Solt $1 /$ & 1387 & 569 & 638 & 1201 & 1534 & 253 & 554 & 1060 \\
\hline tons/A. F。 $2 /$ & 2.9 & .77 & 87 & 1.50 & 2.09 & .33 & .75 & 1044 \\
\hline SoAsR: & 5.5 & 2.7 & 2.5 & 2.0 & 5.7 & .60 & 1.1 & 2,2 \\
\hline Iryedgetion classis: & $\mathrm{c} 2-52 \leqslant$ & $\mathrm{C} 3-\mathrm{s} 3$ & $63=51$ & c3-si & $\mathrm{C} 4-52$ & $62-51$ & C2- 52 & C3-51 \\
\hline \multicolumn{9}{|l|}{ Cacions me/2: } \\
\hline $\mathrm{Ca}$ & 2.52 & 2.64 & 3.52 & 6.08 & $4 \cdot 36$ & 1.64 & 2.77 & 3.12 \\
\hline $\mathrm{Mg}$ & 5.73 & 3.25 & 1.97 & 5.72 & 6.69 & 1.19 & 2.26 & 6.12 \\
\hline $\mathrm{Na}$ & 13.56 & 4.04 & 4.03 & 4084 & 13.50 & .44 & 1.84 & 4.84 \\
\hline $\mathbb{K}$ & .2 & .08 & .03 & .04 & .20 & .06 & .10 & .04 \\
\hline SUI & 21.71 & 9.91 & 9.98 & 26.68 & $24 \cdot 72$ & 3.33 & 6.97 & 14.22 \\
\hline \multicolumn{9}{|l|}{ Anjons ms/3: } \\
\hline $\mathrm{CO}_{3}$ & 0 & .10 & 0 & 0 & 0 & 0 & 0 & 0 \\
\hline $\mathrm{HCO}_{3}$ & 4.25 & 4.40 & 3.12 & 4.35 & 3.12 & 2.68 & 5.50 & 32.05 \\
\hline $\mathrm{Cl}^{\mathrm{SO}}, 3 \mathrm{f}$ & $\begin{array}{l}9.66 \\
7.90\end{array}$ & $\begin{array}{l}1.33 \\
1.08\end{array}$ & $\begin{array}{l}2.32 \\
5.38\end{array}$ & 9.30 & $\begin{array}{r}13.28 \\
8.32\end{array}$ & .45 & .60 & 2.80 \\
\hline 42 SUM & 21.72 & $\begin{array}{l}4.08 \\
9.91\end{array}$ & $\begin{array}{l}5.28 \\
9.72\end{array}$ & $\begin{array}{r}3.03 \\
16.68\end{array}$ & $\begin{array}{r}8.33 \\
24,572\end{array}$ & $\begin{array}{r}.20 \\
3.33\end{array}$ & 6.87 & $\begin{array}{r}2.27 \\
14.12\end{array}$ \\
\hline Number of Samplos: & 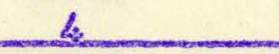 & 1 & 4 & -1 & 5 & 3 & 3 & 1 \\
\hline
\end{tabular}

IJ DLssolved Solsds (prat) calculated from me/1 $\mathrm{x}$ equivalent woight.

2/ Tons/A。 $F_{0}=$ pprn selt $\times .00136$ a

3f $\mathrm{SO}_{4}$ determined by difference, equals difference between cations and anions excluding $\mathrm{SO}_{4}{ }^{\circ}$

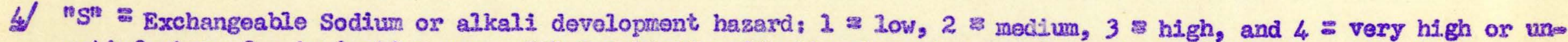
satisfactory for imrfgation use, "C" s Salintty affecting leaching requirements in irrigation use: 1 . 10w,

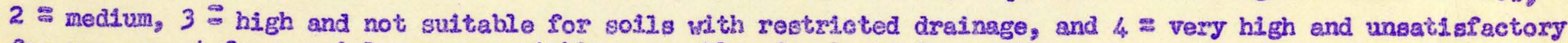
for use except for spectal crops on highly permeable, froely drained solis. 


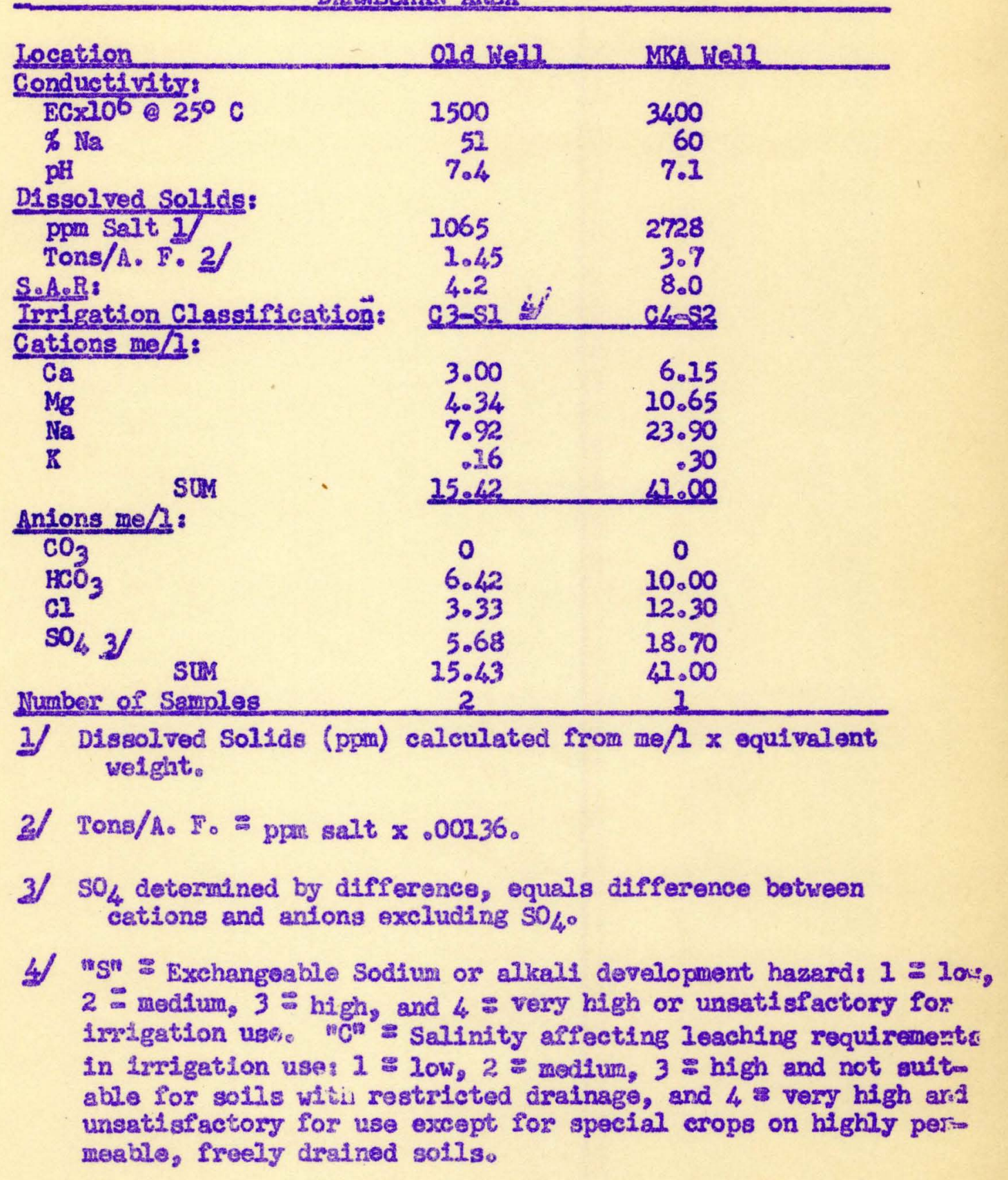




\section{DASTY - T BAIWA AREA}

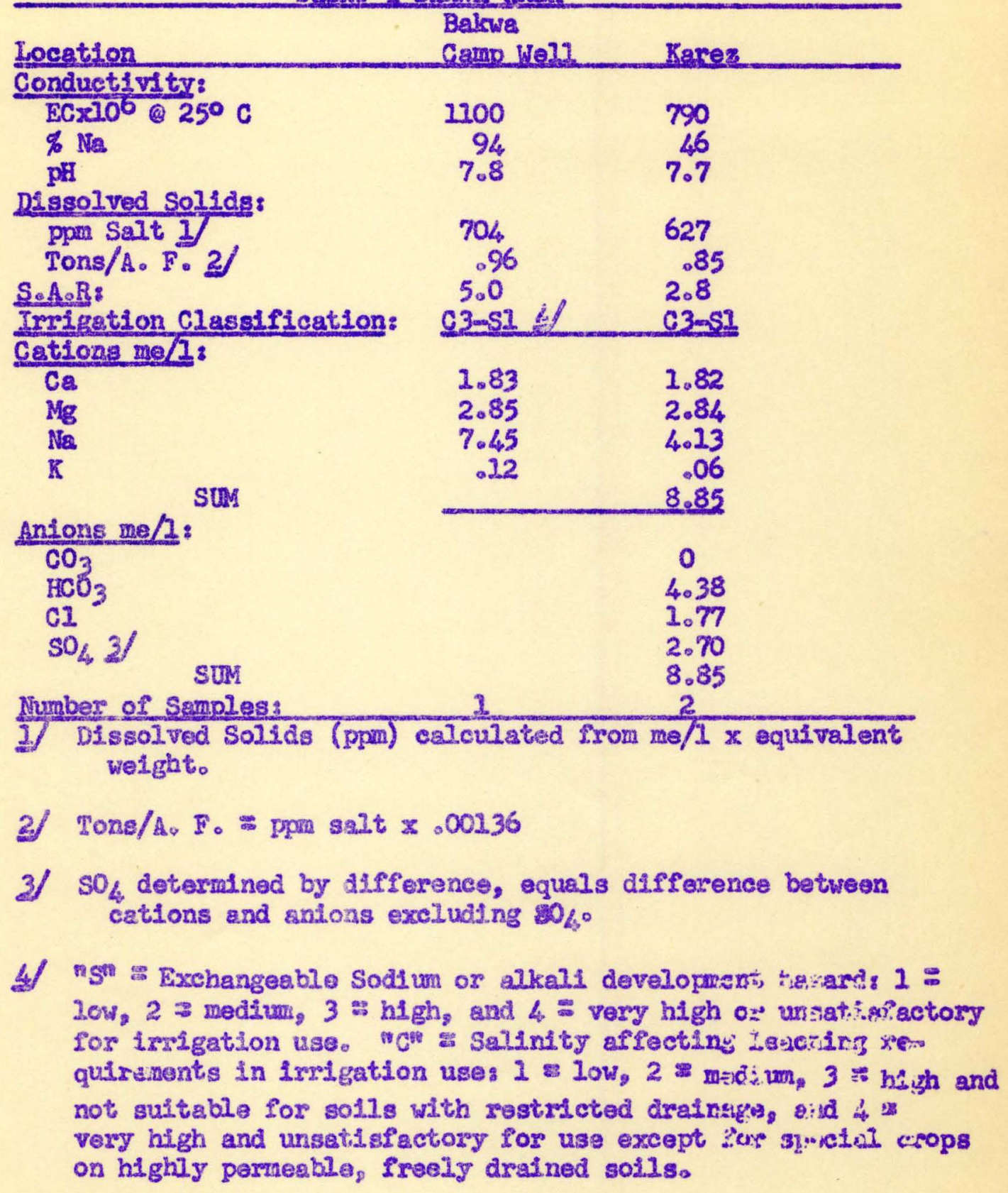


MARJA AREA

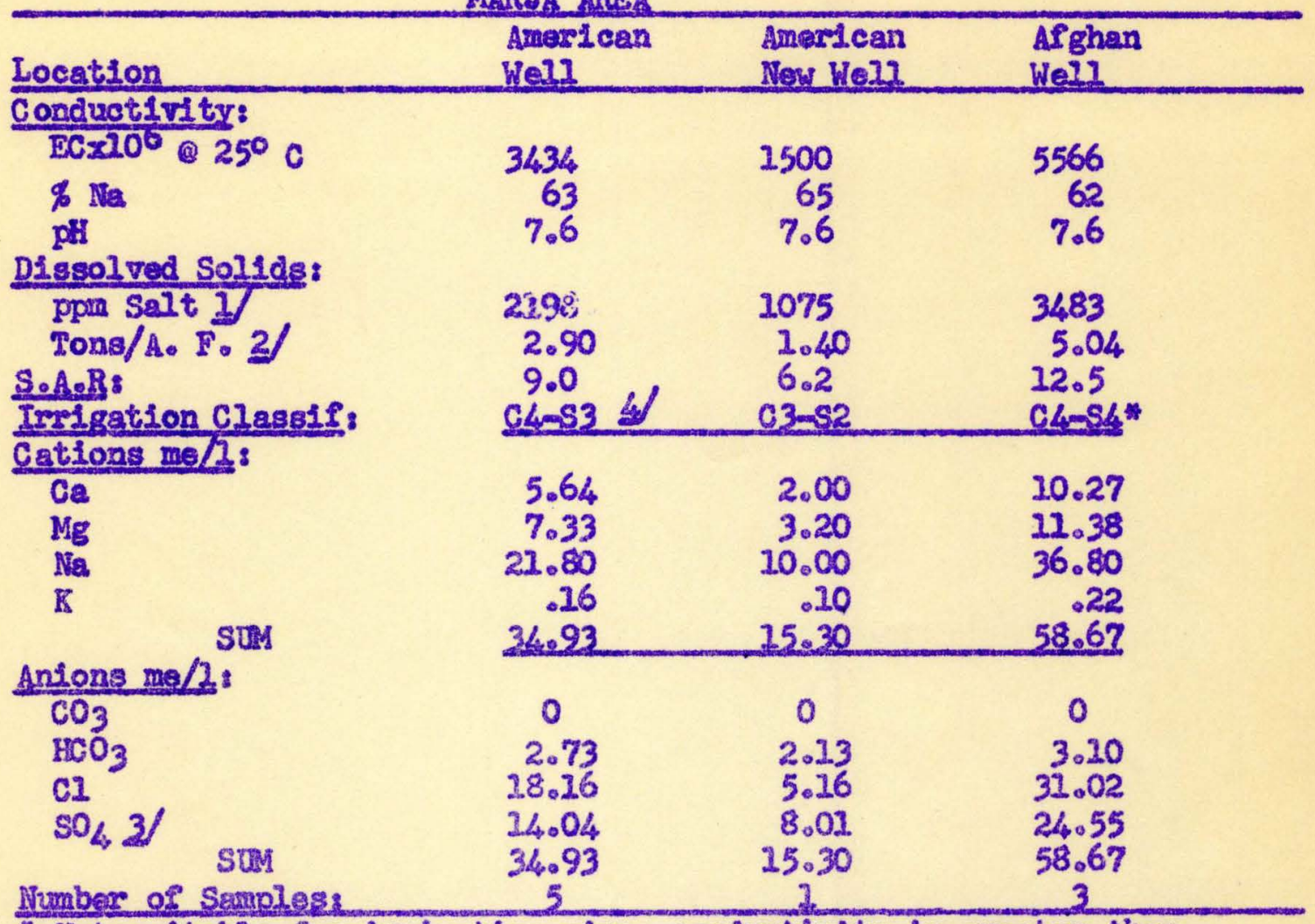

N Not suitable for Ixrlgation since conductirity is greater than $5000 \mathrm{Cx} 10^{6}$

3 DLssolved Solids (ppw) ealculated Iron mo/ $x$ equivalent wolght.

$2 /$ Tons/A. Fo $=$ ppas alt $\times .00136$.

$3 \mathrm{SO}_{4}$ determined by difference, equals difference between cations and anions oxcluding $\mathrm{SO}_{4}$.

4 "g" = Eschangeable Sodium or alkali developwent hazard: $1=10 \mathrm{w}, 2$ * modium, $3 \mathrm{~s}$ high, and 4 = very high or unsatisfactory for imigation use. "C" Salinity affecting leachirg requirements in irxigation use: 1 - low, 2 medists 3 : high and not suitable for solls with restricted drainsge, and $4 \mathrm{\Xi}$ very high and unsatisfactory for use except for special. erops on highly permeable, freely drained soilso 


\begin{tabular}{|c|c|c|c|c|c|c|c|c|c|c|}
\hline Locat1on & $\begin{array}{l}\text { Bast of C } \\
\text { v311age } \\
\text { Woll }\end{array}$ & $\begin{array}{l}\text { West of C } \\
\text { V111age } \\
\text { Wel1 }\end{array}$ & $\begin{array}{l}\text { Hosth of D } \\
\text { V17.1. } \\
\text { Wel1 }\end{array}$ & $\begin{array}{l}\text { D villege } \\
\text { Well }\end{array}$ & $\begin{array}{l}\text { Fed-1-A11 } \\
\text { Fort } \\
\text { Wel1 }\end{array}$ & $\begin{array}{l}\text { Chah-1- } \\
\text { Anjtr } \\
\text { Vel1 }\end{array}$ & $\begin{array}{l}\text { Wo. of } \\
\text { A V111ago } \\
\text { Wel1 }\end{array}$ & $\begin{array}{l}\text { So. of A } \\
\text { V117age } \\
\text { Wo11 }\end{array}$ & $\begin{array}{l}\text { East of } \\
\text { Vi1lage } \\
\text { hel1 }\end{array}$ & $\begin{array}{l}\text { West of } 3 \\
\text { V11 } \\
\text { Holl }\end{array}$ \\
\hline \multicolumn{11}{|l|}{ Conductivity: } \\
\hline ECxi10 $2250 \mathrm{C}$ & 71544 & 3540 & 4360 & 3550 & 1360 & 960 & 4230 & 3580 & 5980 & 5600 \\
\hline \& $\mathrm{K}: s$ & 69 & 61 & 55 & 60 & 32 & 57 & 57 & 52 & 79 & 69 \\
\hline pH & 7.7 & 7.6 & 7.4 & 7.4 & 7.5 & 7.7 & 7.5 & 8.0 & 8.6 & 7.6 \\
\hline \multicolumn{11}{|l|}{ Dissolved Sollds: } \\
\hline ppor Salt $2 /$ & $\frac{5164}{7.06}$ & $\begin{array}{l}989 \\
1.35\end{array}$ & $\begin{array}{l}2909 \\
3.06\end{array}$ & $\begin{array}{l}2336 \\
3.18\end{array}$ & 3331 & & $\begin{array}{l}2669 \\
3.63\end{array}$ & 2371 & 3881 & $\begin{array}{l}4364 \\
5.66\end{array}$ \\
\hline S.A. & 15.0 & $\begin{array}{l}1.22 \\
5.4\end{array}$ & $\begin{array}{l}2000 \\
8.0\end{array}$ & $\begin{array}{l}3020 \\
8.0\end{array}$ & $\begin{array}{l}4022 \\
2.0\end{array}$ & 3.6 & $\begin{array}{l}3003 \\
8.0\end{array}$ & $\begin{array}{l}3026 \\
5.6\end{array}$ & 28.0 & 13.0 \\
\hline$\frac{\text { Irrigation Classis: }}{\text { Cationg moli }}$ & $\mathrm{C} 4-\mathrm{S} 4 \% \&$ & c3-s. & $64-52$ & C.4v-S2 & c3-s? & C3ns $x$ & ChymS2 & $\mathrm{Cb}_{4} \mathrm{~S} 2$ & $C 4-S 4$ 光 & $\mathrm{C} 4-54=$ \\
\hline $\mathrm{Ca}$ & 11.90 & 2.87 & 10.20 & 6.90 & 4095 & 2.96 & 9.20 & 8.60 & 6.35 & 9.20 \\
\hline $\mathrm{Mg}$ & 15.20 & 2.93 & 20.40 & 7.40 & 4047 & 2.08 & 9.20 & 9.00 & 6.75 & 10.60 \\
\hline Na & 56.80 & 9.16 & 25.60 & 22.00 & 4068 & 5.37 & 24.90 & 19.50 & 48.00 & 43.60 \\
\hline K & 40 & .06 & 20 & .20 & .48 & .05 & .20 & .30 & .40 & .20 \\
\hline SEM & $84_{0} 30$ & 25.02 & 46.40 & 36.50 & 14,68 & 9.46 & 43.50 & 37.40 & 61.50 & 63.60 \\
\hline \multicolumn{11}{|l|}{ Anjons me/1: } \\
\hline $\mathrm{CO}_{3}$ & 0 & 0 & 0 & 0 & 0 & 0 & 0 & 0 & .40 & 0 \\
\hline $\mathrm{HCO}_{3}$ & 3.05 & 3.23 & 2.50 & 2.92 & 4.33 & 3.45 & 2.20 & $2 \cdot 40$ & 2.20 & 19.25 \\
\hline C1. & 45.60 & 6.41 & 22.25 & 25.70 & 3.25 & 2.51 & 22.50 & 25.35 & 33.25 & 42.2 \\
\hline $\mathrm{SO}_{4}, 3 / \mathrm{I}$ & 33.65 & 5.30 & 22.65 & 17.88 & 7.10 & 3.50 & 19.20 & 19.25 & 25.65 & 2.15 \\
\hline $\begin{array}{c}\text { SuM } \\
\text { Numbes of Samoles: }\end{array}$ & $\begin{array}{c}84.30 \\
3\end{array}$ & $\begin{array}{c}15.02 \\
1\end{array}$ & 46.40 & $\begin{array}{c}36.50 \\
2\end{array}$ & 14.58 & $\begin{array}{c}9.46 \\
3\end{array}$ & 43.90 & 37.40 & 61.50 & 63.60 \\
\hline
\end{tabular}

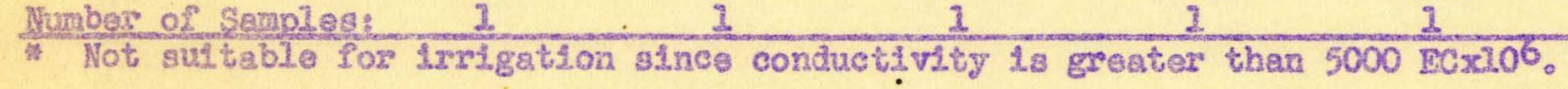

1 Disaolved sollds (ppm) calculated from me/1 $\mathrm{x}$ equivelent wolght。

$3 \mathrm{TOns} / \mathrm{A}_{0} \mathrm{~F}_{0}=\mathrm{ppzi}$ selt $\mathrm{x} .00136$.

3/. $\mathrm{SO}_{4}$ determined by difference, equals dLfferenco botween cations and anlons excluding $\mathrm{SO}_{4}^{\circ}$

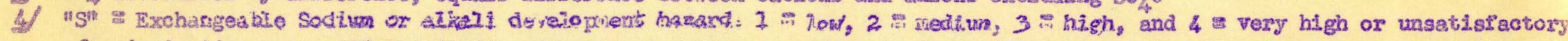

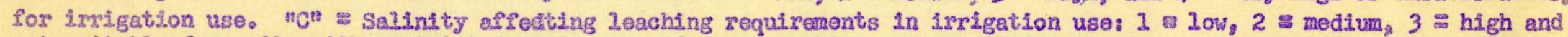
not sultable for solis with restricted drainage, and 4 a very high and unsatisfactory for use except for special erops on highly permeable, frealy drained solls. 
TARHAK APEA

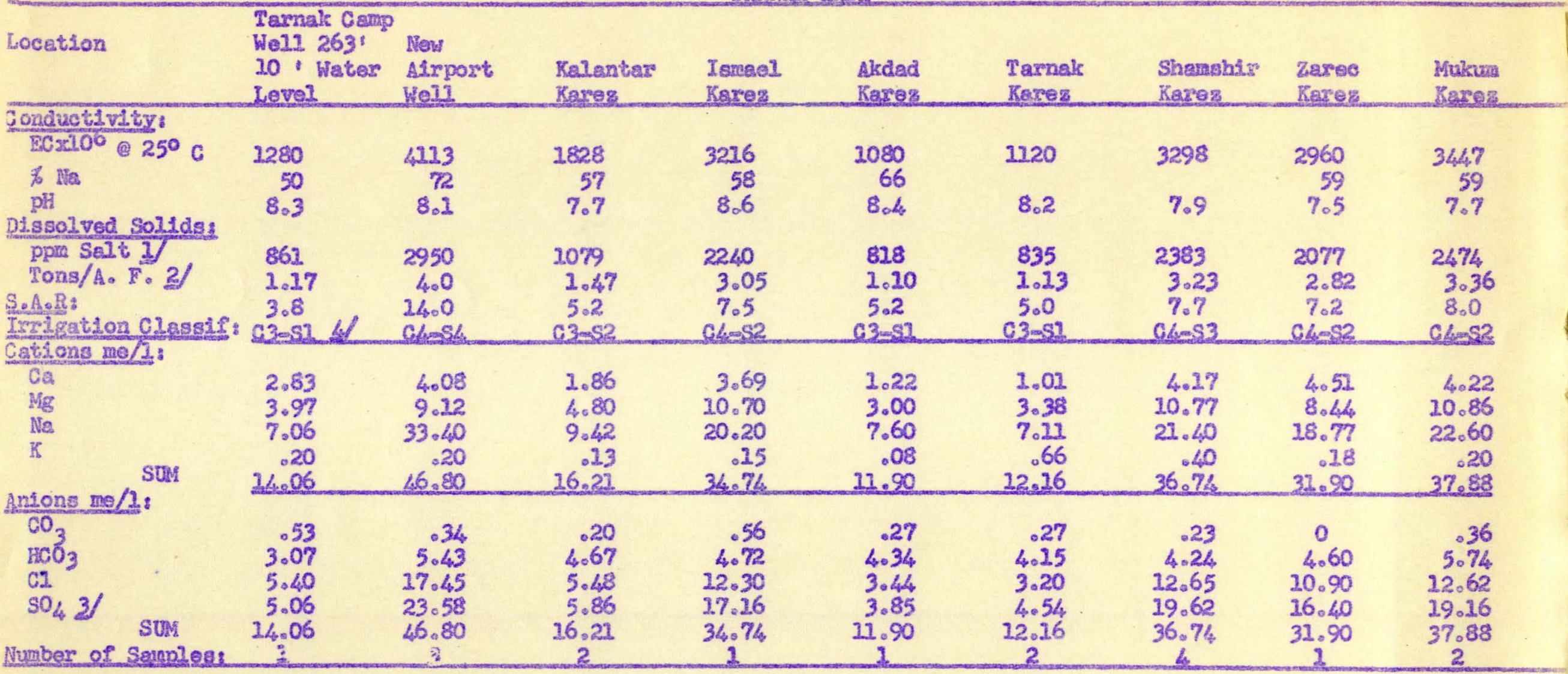

If Dissolved Sollds (ppa) calculated from mo/l $\mathrm{x}$ equivalent wolght。

2/ Tons/A. Fo ppes selt $x .00136$ 。

$3 \mathrm{SO}_{4}$ dotermined by difference, equals difference between eations and antons excluding $\mathrm{SO}_{4}{ }^{\circ}$

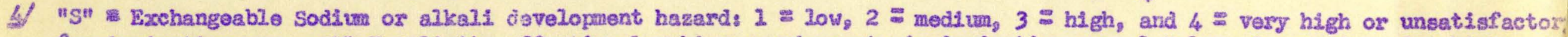

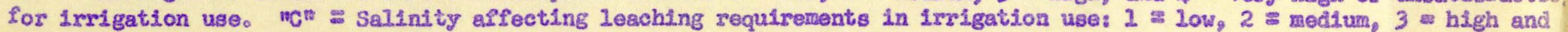
not suitable for solis with restricted drainage, and 4 very high and unsatisfactory for use ercept for spociel crops on highly permeable, freely drained solls. 


\section{9}

Table

GROUND WATER ANALYSTS REPORT

$7 / 30 / 57$

\begin{tabular}{|c|c|c|c|}
\hline Location & $\begin{array}{l}\text { G1riskok } \\
\text { Wel1 }\end{array}$ & 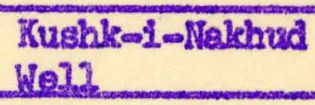 & $\begin{array}{l}\text { Lashlearga } \\
\text { Yel1 }\end{array}$ \\
\hline Conductivity: & & & \\
\hline 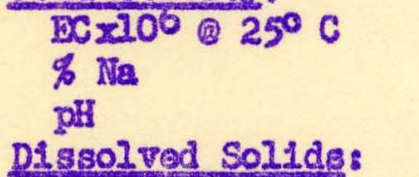 & $\begin{array}{r}865 \\
72 \\
7.3\end{array}$ & $\begin{array}{r}700 \\
42 \\
8.1\end{array}$ & $\begin{array}{r}990 \\
46 \\
7.7\end{array}$ \\
\hline $\begin{array}{l}\text { ppom Solt } 1 / \\
\text { Tons/A. F. } 2 / \\
\text { S.A.R : } \\
\text { Imelgation Classif: }\end{array}$ & $\begin{array}{l}691 \\
.94 \\
1.2 \\
63-5144\end{array}$ & $\begin{array}{l}495 \\
.67 \\
2.2 \\
02-51\end{array}$ & $\begin{array}{l}694 \\
.94 \\
3.0 \\
63-51\end{array}$ \\
\hline Gations me/1:8 & & & \\
\hline $\begin{array}{l}\mathrm{Ca} \\
\mathrm{Mg} \\
\mathrm{Na} \\
\mathrm{X}\end{array}$ & $\begin{array}{l}4.19 \\
2.98 \\
2.06 \\
.26 \\
0.10\end{array}$ & $\begin{array}{l}1.76 \\
2.48 \\
3.25 \\
.20\end{array}$ & $\begin{array}{l}2.90 \\
2.96 \\
5.02 \\
.04\end{array}$ \\
\hline Amions mo/h: & 9.49 & 7.59 & 10.92 \\
\hline $\begin{array}{l}\mathrm{CO}_{3} \\
\mathrm{HCO}_{3} \\
\mathrm{CI}^{2} \\
\mathrm{SO}_{4} 2 / \text { Sam } \\
\text { Numbar of Samples: }\end{array}$ & $\begin{array}{l}0 \\
6.22 \\
1.46 \\
1.82 \\
9.49 \\
2\end{array}$ & $\begin{array}{c}.13 \\
3.20 \\
4.26 \\
0 \\
7.59 \\
2\end{array}$ & $\begin{array}{c}0 \\
2.63 \\
3.30 \\
4.99 \\
10.92 \\
2\end{array}$ \\
\hline
\end{tabular}

If Dissolved Solsds (ppm) caleulated from mo/2 $x$ equivalent velght,

$2 /$ Tons/A. $F_{0}=$ ppm salt $x .00136$.

3/ $\mathrm{SO}_{4}$ determined by difference, oquals difference between cations and anions axcluding $\mathrm{SO}_{4}$,

4f "S" Exchangable Sodium or alkall dovelopwent hazard: 1 : Low, 2 mediun, 3 = high, and 4 s very high or unsatisfactory for Irrigation uge. "Cle salinity affecting leaching reguirements In 1rrigation uve: I low, 2 medium, 3 migh and not suitable for solls with restricted drelnage, and 4 is rery high and unsatisfaces tory for use except for special arops on highly perneeble, freely drained solis. 
APPENDIX III

DEVELOPRENT COST EST DMATES 


\section{MOREA ARGHANDAB AREA (Woxk Shoet For Cost Estimate)}

A-1. Not IrrLgable axoss acros, 67,635 as mesured by planinetax stom sol.1 survey map, Gross Irr.Igable = 48,659 Acros. Whon developo ment losses are deducted for C2nss IV lands not watrad for zoods cands. ato. the net area $v i 17$. be 40,235 soreso

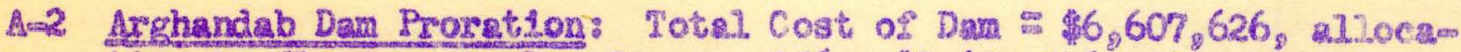
tion to Ilood control and power $25 \% \$ 1,652,026$ which lexva \$4.955,600 to be prosated over 194,025 eares of Jando Proxaton to Worth Arghandab,

Am 3 Cost of Nalgam DIvorsion and 9 intsks controls for canals abowo Mal gam and below Asghandib Diversion Dava Malgan Diversion Dam estiDated cogt: $\$ 665,000$ promate $\frac{1}{2}$ to $N$ 。 Arghandab Ares: 332,500 9 canel intake controls at $\$ 6,000$ aeks 54,000 Lettar Ackerman to Johnston 12/31/53 Total,

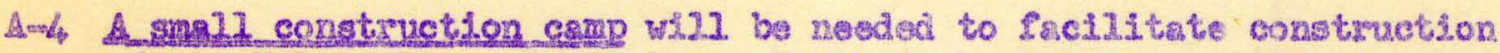
of the linlgan Dan and canals to North Arghandeb Arose and to Lower end of Central. Arghandib Ares. Estimate by Gavin for this carposos 200,000

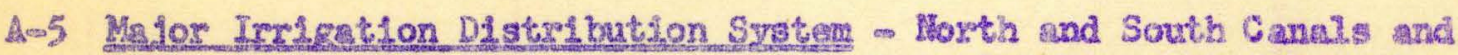

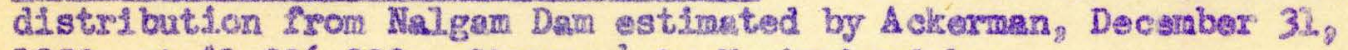

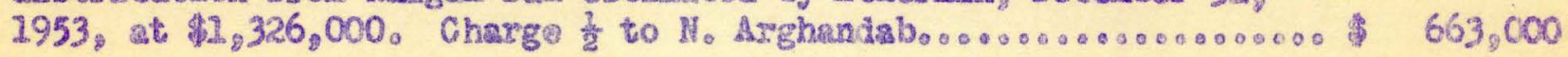

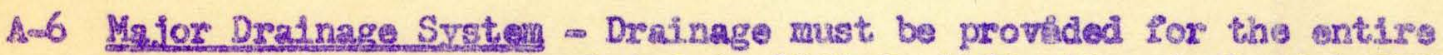
arese Costs were calculated in 1953 justLficstion Arghasdab Valley Developunat, page 19. Cost from estlmate: 362, 828

Interseptor drains must be acded to the gross usable aras 48,659 acres at a cost per acre used in the abowe astimate of $\$ 16.51$ per scre $=48,659 \times 16.51=$ Total.

$$
\frac{803,605}{1,666,433000 \text { क }} 2_{2} 666,400
$$

A-7 Interproject Roris a none lucluded - thare w117 be ronds on canal and Iatorel banks. Kandahar to Gixishk Road rvus along north side of the sxee and w\$1 serve 1 t.

A-8 ILle Draing (cale. at MKA costs Nad-j-171). It is ostinated from romeasurements of the soll survey and drainage naps $(8 / 25 / 56)$ that 18,760 acres w1.11 require t11. drains on 200 meter specing or 375

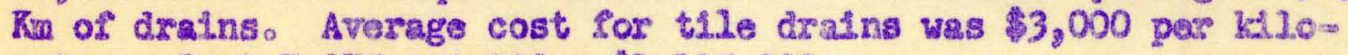
meter. Cost $=375 \times 3,000 \equiv \$ 1,125,000$ \$ $\$ 20000000000000000000$

A $=9$ Sublatorgl snd Faru Djtohes (At ACV netual costs of April. 1956). Average cost pere nere sublatorsls and plakup drelns (ACU) $=22.33 / \mathrm{A}$ Total costo Arerago cost par acre Ferro Ditehes and Irrm plekup dxains : 9.73/A Total cost. Sublaterals and accumulator drán.n. wi1l be needed on 25,000 acres or cost $\% 25,000 \times 22.38=7560,000$

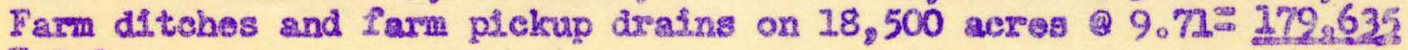




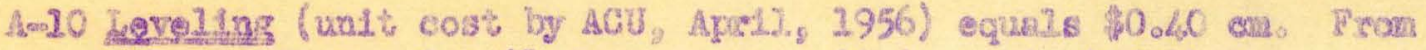
the dralnege and so1? survey taps, 1 it is ostinatod that

Loveling 15,170 acres (c) 150 ch per note $\times 0.40 / \mathrm{cm}$. 00000000000

An11. This work to be coutributed by the poople is based on dollar Qq. lesching irrigations. Frora soil surveys it is estimated 15,200 acres need such treatment or $15,200 \times 8.130 \ldots \ldots \ldots \ldots \ldots \ldots \ldots$

A-12. Total cost in dollars on 1 a the sum of Columas 2 thra 11 and is the estimated total ocvo, cost of the projectoon o.

A-13 Cost per acre In de17srs - Is the estimatod total cost of the prow ject (Colum 12) divided by the number of acres (Colum 1) of not irrigeble land: $6,841,635 \& 40,235 \approx 5170.04$

NOTE:Only $\$ 2,027,600$ (Iten A-2) is expended to dat, A17 other 1.tems aro estinsted as contractors cost plus foes or ACU costs plus overhead. Serlous consideration glven to developnont of as much as posstble by pritrate captisl and faxmer labor could result in substantial1y lower total cost and in less denand for use of form eign currencies。 


\section{CENTEAL ARGHANDAB AREA (Work Sheat for Tsble I)}

B-1. Gross Areq - 332,220 acres, gross 1xrigable - 88, 166 acres and not irrigablo $-80,4750$

B-2 Arghendab Dam proxated cost is based on alloceting $25 \%$ of cost to Ilood control and power and the balanes 1.5 prorated over 19/4,025 acres. Allocation to Contral. Arghandisb 80475 $\times 4,955,600000000$

$B-3$ Diversions and maln cann $1 \mathrm{~s}$ - budget reviston $8 / 7 / 56$ by Shockley ostimates Arghandmb dIversion cost as $\$ 954_{8} 270$ and the cost of Arghandab So. Cans Ineluding blfurestion and wastomay works as $\$ 2,083,3440$ This system will serve 60,689 acres in Central Axm ghandab and 64,350 in Taxmak. C. Arghandab proportion of $48.54 \%$ $\$ 1,475,350$. Tarnak Cand w111 serve 4,023 scres of Central Ax= ghandab Iands or $5.8 \%$ is chargeable to C. Arghandab. Shockley's budget revision $8 / 7 / 56$ shows $\$ 2,639,279$ as Tarnak Canal cost or

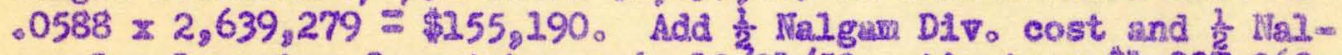
gen Canal systea from Ackerwan's 12/31/53 ostinate $\$ 1,037,263$.

Total estingte.0.

Bn-4 Work Camp estimated same as Tarnak。

B-5 Maior Irrigation Systom - estinsted equiralent to Tamak costa.oo

B-6 Major Drainage Sxston - included in B-5 bove

$2,667,803$

170,000

$3,206,500$

(1ncl.)

(inclo)

ax Included In B-5 and $8-6$ costs above.0...

B-8 Farm Tile Drains - soll survey shows 17,000 acres with present water tables from $1^{\prime}-5^{3}$ below surfince, and 35,000 acres needing leaching now Not 2.17 will be drained or leached now $\left(14_{8} 000\right.$ acres are considered unsuitable for present development)。 Dratns needed now are estimated as 6,000 - $100 \mathrm{~m}$ spacing $\times 114.74$ $=\$ 688,440$. 20,000 (200 m specing $\times 57.37=\$ 573,700$ 。

Total estingted tile drains................

$1,262,140$

B-9 Sublaterals and eccumilator surface drsins - w111 be sequired on 56,000 acres at a cost of 22.38 per sere or (ACU's total coet as of 5/56) 1,253,300. Ferm ditches and farm pickup dralns will bo needed on $41_{8} 000$ acres at cost of 9.71 per acro (ACU est.) 400,000 . Total sublaterals and farm ditches.

B-10 Land Laveling - Irom drainage and soil maps, it is astimated: 181 acres swnd spreading and desp plowing $154070: 28,005$ 4000 scres brush clearing and grubbing @35.71 4000 acres rough leveling 73.41 8000 ncres moderste leveling (2) 72.50 8000 scres diskting loveling (2) 7.38 12,181 acres Iand planing @ 7.92 142, 140 $=293,640$ 580,000 59,040 $=96,475$

Total elearing, leveling etc 000000000000000000000000000000 


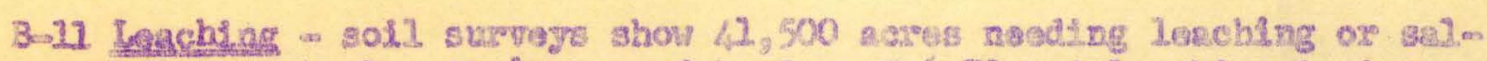

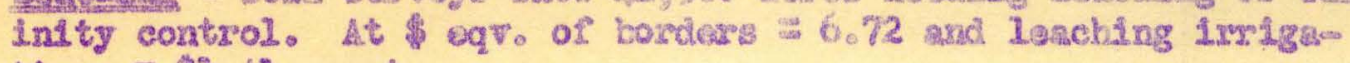
thons = \$1. \$1, costopos0000000000000000000000000000000000000000000

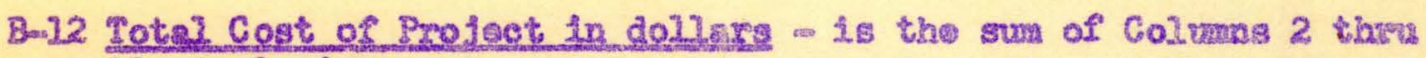
11, Inelush

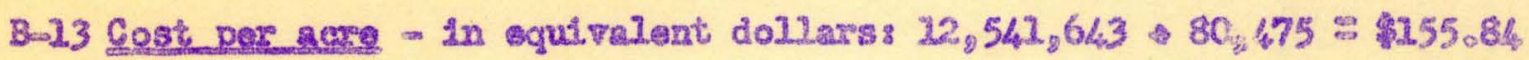

Hote: Does not inelude estimate of costs of present development or portlons which wourd be usshle in the completed projecto Privato captial and farver effort coldd probably do most of voris Items B-8 through B-11 and thoreby considarsbly reduce tho total needed for compl te developanento 


\section{TARNAK AREA (Work Sheet for Table I)}

G-1 The gross ares contains 1210,655 acres of which 74,550 is irrigable or realain able. Due to shortage of , 64,350 acres of the better lands will be selected for developmerst.

C-2 Arghandab Dam prorated cost is based on allocation of 25\% of cost or 1,652,000 to flood control and power and the balance $4,955,600$ is prorated over 1954,025 acres. Allocetion to Tarnak Area $=\ldots \ldots \ldots \ldots \ldots \ldots \ldots \ldots \ldots \ldots \ldots \ldots \ldots \ldots$. $1,643,826$

C-3 Cost of Diversions \& Canals - in the $8 / 7 / 56$ revision by D. R. Shockley, Arghandab diversion dam is estimated to cost $\$ 1,062,297.42$ and South Canal to and incl., bifurcation and wastewey works to cost $\$ 2,074,396.77$. These works wi.1I serve 125,050 acres of which $51.46 \%$ is in Tarnak area.... Tarnak portlons $\$ 1,614,400,13$. The Tarnak Canat is estimated to cost $\$ 3,107,281.58$ of which on] $\$ 182,708.15$ is chargeable to C. Arghandab and $\$ 2,924,573.43$ to Tarnak. Total cost diversions and canals $\ldots . . \ldots \ldots \ldots .$.

Col4 Buildings and Improvements - a small construction camp supplemental to Manzel Bagh. Taken from Target Estinate (11/27/55).

Co6) Major Irejgation and Mafor Drajnage System - taken from Target Estimate

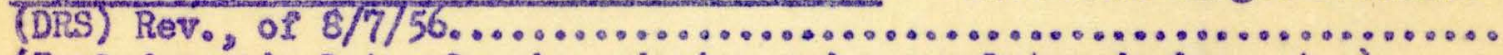
(Includes main laterals, deep drains and accumalator drains, etca)

Co7 Interprofect Roads - None - Area is served by Kandahar - Spin Baldak Road on North and on-project roads are Included in $\mathrm{C}-5$ \& $\mathrm{G}-6$.

(incl.)

Cos Farm T11e drains - data from so11s and general drainability surveys Indicate the following at $\mathrm{ACU}^{\circ} \mathrm{s}$ urit costs: 20,044 acres of drains (a) $100 \mathrm{~m}$ or less $\times 114.74=2,299,849$ 23,193 acres of drains (a) $200 \mathrm{~m}$ spacing $\times 57.37=1,330,582$ 4,800 aeres of drelns over 200 in spacing $x 38.34=184,032$ Cost total tille drains.

Co9 Sublaterals and Farm Ditches -

Sublaterals 68,000 acres $\times 22.38$ per acre (ACu est.) $=1,528,900$ Farm Ditehes 68,000 acres $\times 9.70$ per acre $n "=\frac{659,400}{0}$

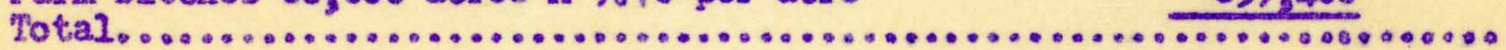

C-y IO Jand Ieveling - Prom solls surveys and based on ACU unit costs: Brush clearing - 24 acres (acUis) $35.72=$ Rough leveling - 24 scres (c) 73.41 = Mod. leveling $-16,720$ acres @ $72.50=$ Heavy leveling $-1,602$ acres (1) 90,00 . D1.sking - 13,637 acres @ $7.38=$ land plowing 31,983 acres (1) $7.92=$ 857,00 Total clearing and leveling. 
C-13 Land reclanstion - Leaching of 13,400 acres, cost of borders and basins at 6.72 and cost of leaching $\left(1,42, \ldots \ldots \ldots \ldots \ldots \ldots \ldots\right.$ \$ $208_{8} 900$

C-12 Motal cost Project in Dollars - is the surs of Columns 2 thru 11, inclusive ............................................ $\sqrt{17,383,863}$

C-1.3 Cost per acre - in dollars: $16,891,24,2+64,350+\$ 270.10$ 
Seprowbar 10,2955

Revised $12 / 6 / 55$

Reviged $8 / 28 / 56$

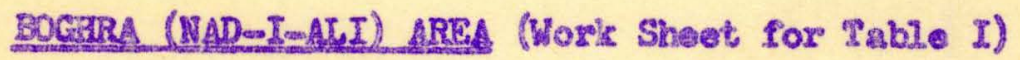

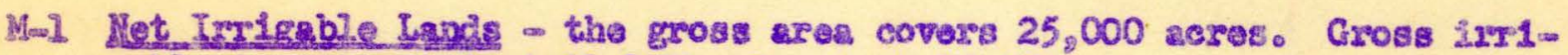
gabla is estiveted at 21,100 and not at 18,500 .

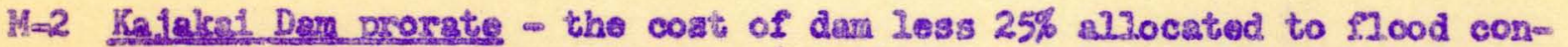
trol and power is prorated ovar 647,900 acres of Iand for which dan can

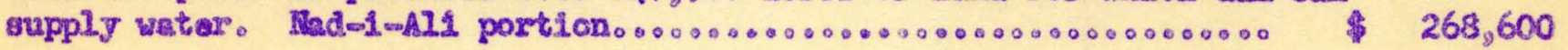

M-3 Cersts and Diveraions c-

I. Boghra Difo Dan \& Canal (Sched. I-II of 1946 Contract (to sta tion 31 - 800) shows cost as $6,963,515.67)$. Allooet ion by $\%$ Inad served : value $\mathrm{x}$ a $169=$ $1,176,834,15$

2. Boghra-Marja-Shawelan (Sched. III-IV of 1946 Contract and cont w pletion in 1950 Contrect $=5,362,893.73$. Vad-1-171 proportion : $.3357 \times 05 x$ value $=\quad 900$ 261.72

3. IIning Boghrawaxja Canals (Suppl。 $\$ 11$ Compo) = $103,792.95$

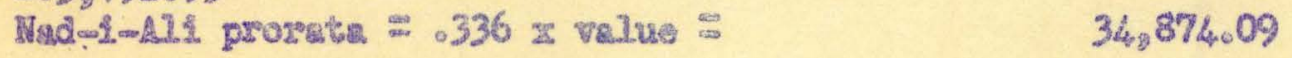

4. Boghrea $0_{0} \& M_{0}($ Suppl. 44$)=$

$2,152,850,00$

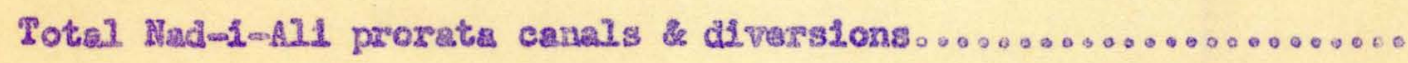

(See $M\left(\begin{array}{ll}* \\ \text { ) }\end{array}\right.$

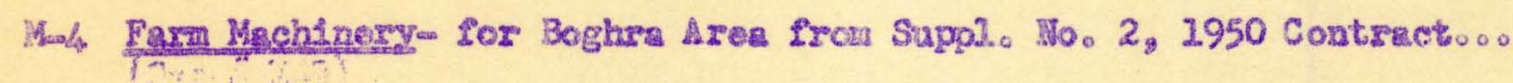

Mos5 Comploto Ire. Sratom (Inc?. also a majox part of Ma 9 )

Supplensata? Contract 1 I.

1950 Contr. Nad-i-al1 Dtv。 Das -

Supp。 th1 Ird-1-Al1 Completion is

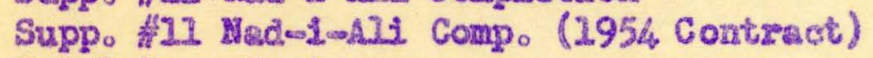

Total Im。. Systeras o
$335,670.72$

$116,954,60$

435.181 .87

$114,450.07$

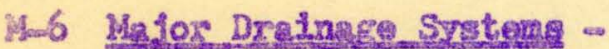

Suppl. $19\left(\right.$ Engro $\left._{0}\right)=$

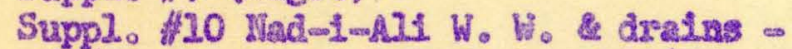

$8 / 7 / 36$ Est. to complete by DRS $(18$ lne dxanne

(2) $\$ 8000 / \mathrm{kas})-80 \mathrm{kmn}$ (1) $\$ 6500$

Tots 1 Major Draina

520.090 .00

He7 Interprolect fo on-prolsect Bopds -

Suppl. 42,7 arm secess Roads -

$112,004,32$

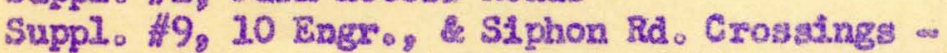

$39,606,87$

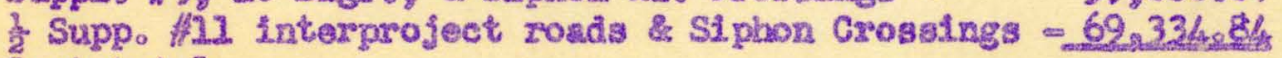

Cost total. 


\section{7}

Mo8 T270 Drainas: - est. by ACU as 18,500 acres (200 spreing) (2)

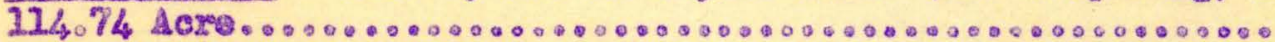

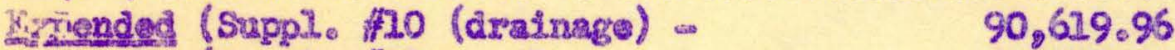

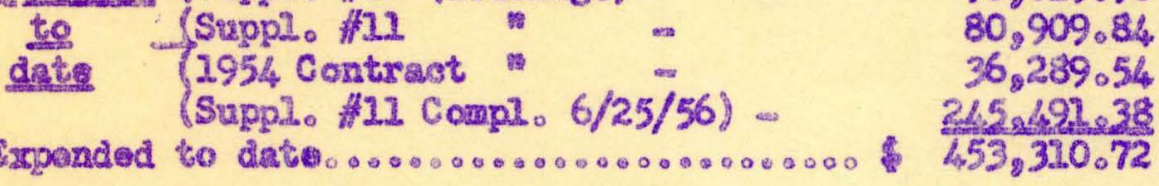

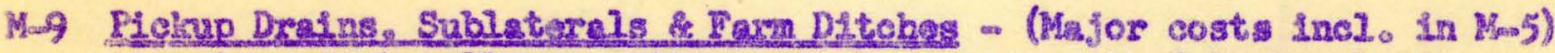

A 3eriss of miscollanocus items which vere an part of Bogbria laud development inelude the folloulng:

1946 Contrsct Nad-i-Ali Experimental Farn $=128,271.37$

Suppl. \#2 (Farn Machlnery) - $56,8 \%, 8.42$

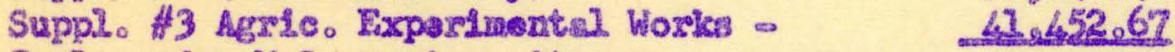

Incl. under Mof as mise. Iftemg

3. $226,572.00$

Monlo Land Levaling -

Suppl. contxoset $\frac{1}{2} 2$ -

Sched. VII 1950 outonofocontrect ficenss

(land prep. and seeding) .

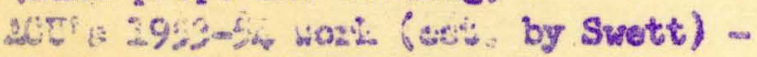

Charges to kand levelfage 00000000000000000000000000000

25.275 .69

61.703 .55

$38.295 \times 45$

\$ $106_{2} 176.00$

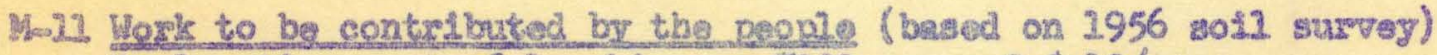
Roclaustion cost of leaching on 7000 acres 8 (8) $13 /$ aers 000000

* $\quad 56,910.00$

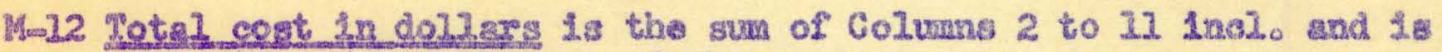
the estinsted totel cost of the project.00000.0000000000000

Mol3 Cost oar sore - In dollars 1. tho estimated total cost of the prom joct (Colwen 12) divided by the nuber of ncses (Colun ij in the projoet $6,542,975 \& 28,500=\$ 353.67$ 
Soptenaber 10,1955

Revised $12 / 6 / 55$

Revised $8 / 29 / 56$

MAREA ARAA (Work Sheot for Rablo I)

N-1 Nat Irrigable Hand - the Guss surveysd area Inelucied about 4,5,000

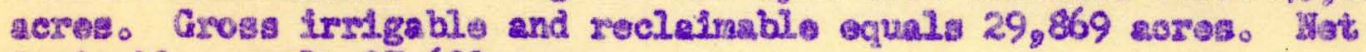
Ixrelgable equals 27,600 scres。

N-2 Kaiska Dam cost - Less 25\% allocatod to flood control and power. is prorated over 647,900 scres of land for whith daw can sapply พator. Marja portilon,

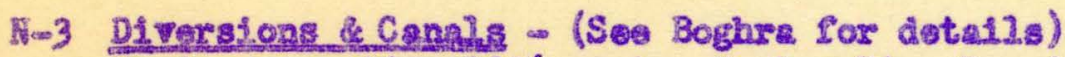

Mrrja proportion 1946 contr. Boghre DIF. Dax \& Sched. I-II - 1,754,805.95

Marja proportion 1946 Sched. III-IV, \& 1950 Cortacet $-\quad$ 1.340.723.43

Marja proportion canal lining (Suppl。 11 complo) - 51895.98

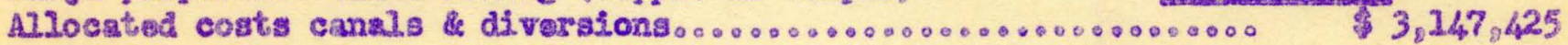

Nook. Buildings \& Imnovrenents -

Suppl. 1111950 eontrect - $228,721.78$

Supp. H11 Comp1. 2954 contract $(6 / 25 / 56)-\frac{553,788.17}{782,509.85}$
Mar ja Camp Costs -

A7locata 2/3 Harja \& I/3 Shamalan 000000000000000000000000000000000

$\$ \quad 521,934$

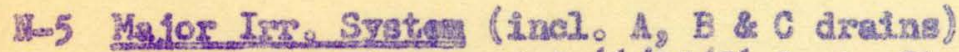

1954 Contract mspended (6/25/56 Cort. Strimenent) - $\quad 2.135,964,00$

Das $8 / 7 / 56$ est. to complete -

$$
\frac{325,558.00}{2,441,522.00}
$$

A. B \& C draina asto (2) $52 \mathrm{~km}=15,000=$

Maxja dilee (2950 Contzect) -

$\approx 780,000.00$

$76,915,93$

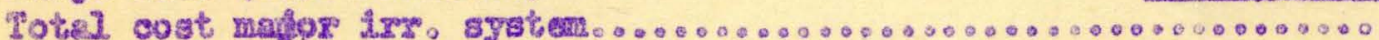

$1,736,438$

1 6 Mgiox Draingos. Syetga =

A, B \& C dralng ast. 응

Est. additional drelnage (DRS $8 / 7 / 56$ )

Lass 1200 Acc。 คลา draมี 200 in

spacing and 3500 low

$780_{2}, 000$

$\frac{1,000,000}{1,780,000}$

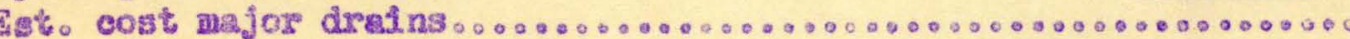

$\$ 1,610,000$

How Iptergyolect Rosis as

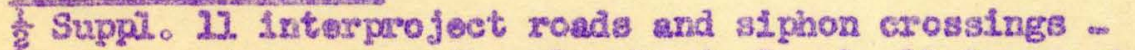

Iritarpajoct roads Shsanlan-War Ia Suppl. 11 Coutract -

completion $6 / 25 / 56$ cost statmont

$69,334.8 \%$

Total.

$13,923.88 \%$

000000

\$ 88,259

N-8 Parm Dreing -

Swott $8 / 25 / 56$ ACI ast. 27,600 sares 200 m spo cost

$57.37 / 4 \Rightarrow$

DRS $8 / 7 / 56$ ost. 898 kna $13500=$

$1,583.400$

$30.3,000$

Estimite: AVgo of 2 Ahove gtatranert\$00000000000000000000000000000

霄 $2,363,400$ 
11 $\rightarrow$ Syblaterals and Farm Ditches from ACJ operation schedulo and $8 / 28 / 56$ estimete $=618,300+266,200, \ldots \ldots \ldots \ldots \ldots$.

$\$ 884,500$

Rom 10 Land Loveling as from Soll Surveys and axperience costs to dat, the cost is ostimated as follows by ACU: Deap plowing 1115 acres 275.97 . Sand spreading 1115 acres $159.00=$ 84,706 Moderst 1*veling 8.120 aros 72.50 c 177,285 Hoavy loveling 1115 seres $90.00-$ Dising 20,245 acres 7.38 Land planing 9,335 aeres $7.92=$ 588,710 100,350 75,608

Cost total Iand weparation 73,342

Mol2 Innd Reclanation by the people - Act estimates $8 / 28 / 56$ that the people uhl工 do lesching 8.23 per wor on 10,338 acres or cost.

89,000

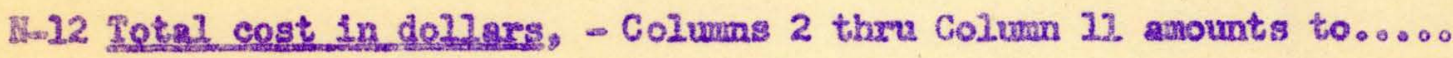
\$ำ, 942,556

Hel3 Gost par acre - In acuivalent dollaxs Lis dexivad as 11,947,556 * 27,600 ox $\$ 432,66$ 


\section{SHAMALAN AREA (Work Shogt for Mable I)}

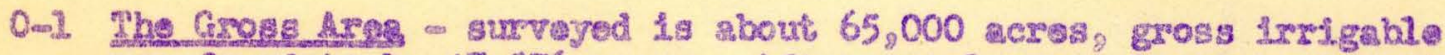
was found to bo 47,876 rexes. After developasnt 1ossas, the not scros agual 42,325 scros.

0-2 Kajeka. Dam proration - cost of dan, lass 25\% allocsted to 1200 d control and power, 1 prorated ower $6 / 7,900$ acres of Innd for which the dam can supply watar. Shamalan portionso000000000000000 000000 \$

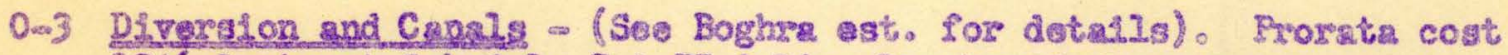
1946 Contzact Schodvie I \& II \& D2V. Dam based on acreage aervad. $.388 \times 6.963,515.67 \approx$ prorata cost 1946 contract schedule IIT \& IV plus 1950 Conkret $=.50 \times 6,362,893.73$ \%

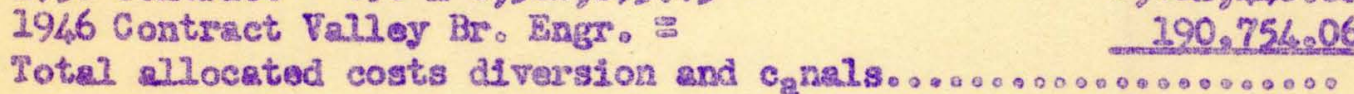

O-4. Buildings and Improvements - (See Maxja Work Shent) allocate 1/3 Mar fa Canp e.333 $\times 782,509.85$. $2,701,844,08$

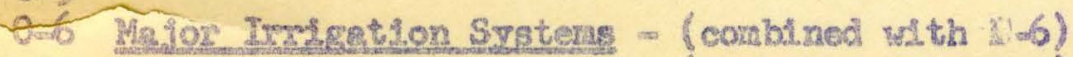

Haior Draunges Srgters $\Rightarrow$ (comblned with -5 )

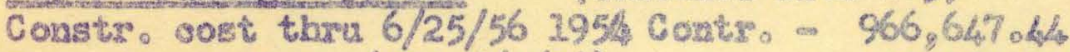

Est. to conploto (DRS $8 / 7 / 56$ ) $\quad=430,08$, 00

Total 00000000000000000000000000000000000000000000000000000000000

0-7 Intoresrolect and On-Pxolect Ronds - 1950 Contract Shamelan Rdo (pors $3 / 31 / 55$ Statevent) $=$ a rosds in 1954 Conkr. completion of Suppl。 M11 $(6 / 25 / 56$ Cost Stat. $)=$ $309,021 \cdot 02$

Total. 19. 923.85

0-8 Frrm Drains - estinated by ACU as foljows:

11,388 z.cres(0 200 a spectag) $\mathrm{x} \$ 57.37$ per acre plus 10,375

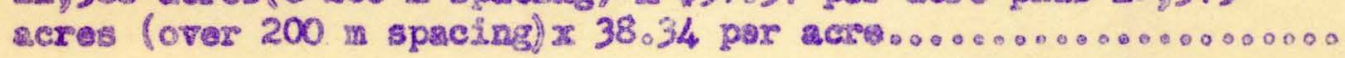

0-9 PLckup drains sublaterals bassd on ACU est. $8 / 27 / 56$ @22.38 per scre on 448400 acres Farm ditches ACU est. $8 / 27 / 56$ 잉 $9.71 /$ sere or 16,000 acros : 993,600

Total ACU eat 157,200

0-10 Clanring \& Loveling - (ACU cost sstinnto basad on sol1s survey acreage):

Sand spreading on 800 acres 159.00 (1) brush clearing on 1795 acres 35.71 : Rough leveling on 1795 acres 73.41 औ $127,200.00$ Moderate leveling on 13,495 acres (8) $72.50=$ $65,000.00$ Diaking on 11,700 acras $97.38=$ $131,771.00$ Land planing on 13,495 actoss 7.92 . Totenl alenxing sxd leveling 


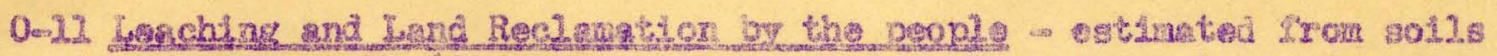
survey thet 10,600 serss will need hoary lemehingo Cost of borters (ACU $8 / 27 / 56)=6.72$ and 1xrigations 2.41 por acse。

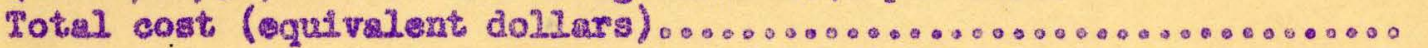

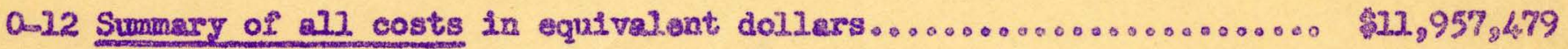

0-13 Average per acre cost $\equiv 11,957,479-142,325=\ldots \ldots . \$ 282.45$ 


\section{DARWESHAY AFIEA (Woots Shoet for Teblo I)}

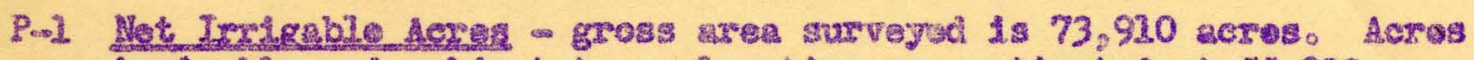
irrigable and subject to roclanatlon are atinatod at 55,000 acres;

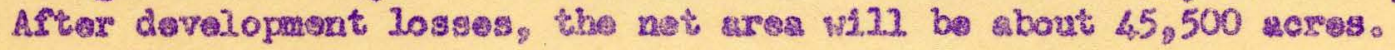

P.a2 Kajokgs Dgn prorntion - cost of dax Lass $25 \%$ allosated to $100 d$ control and power $1 \mathrm{~s}$ proreted orar 647,900 aeres of Iend for wh1ch

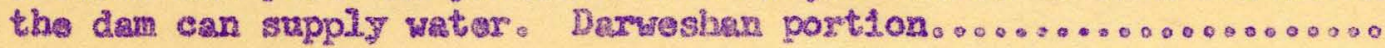

Po-3 Daswashan Intgke Structure - fron (DRS) estiants of $8 / 7 / 56$ was $\$ 515,518$. The Hazar jof $f$ supplemantary canal was $\$ 99,960.0000000$

Pos Gonstruction Comp o is estimeted (DRs $8 / 7 / 56$ ) atto00000000000000000

P-5 Major Irrigation DIstribution and

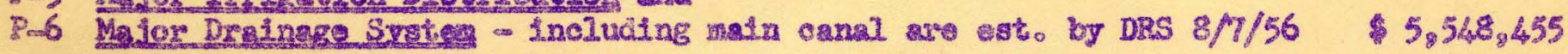

P=7 Jateroprojset Bosd of Irom Marja Area to Darwosban and Darweshan brige $(6 / 25 / 56$ cost statcment)

Dreins: - ACU osthmatos 8/26/56 from so11 survoy maps:

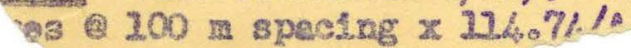
रूस 280

(c) 200 mpang 